
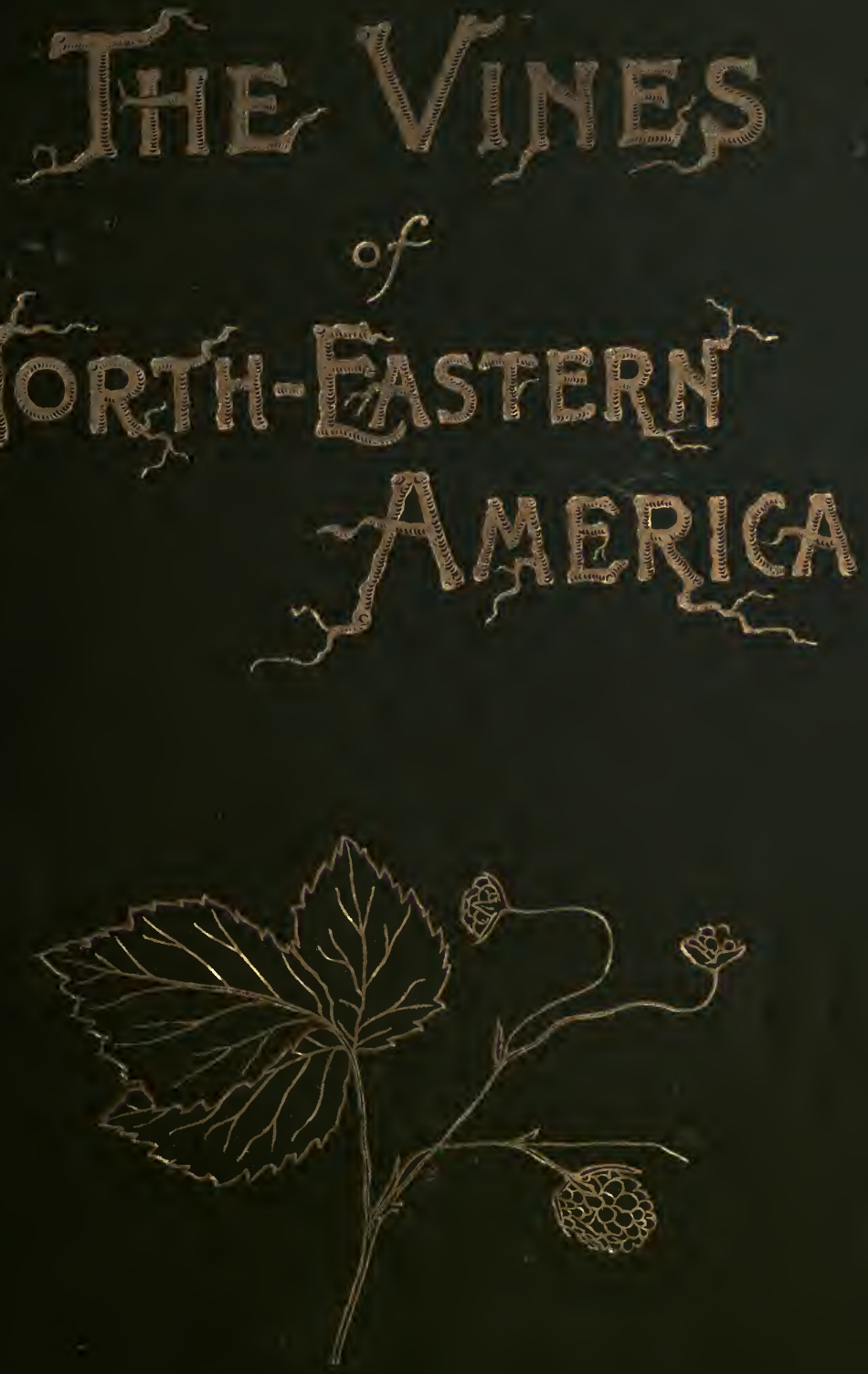


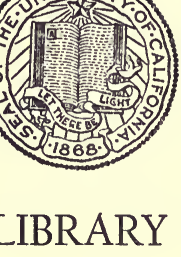

THE UNIVERSITY OF CALIFORNIA SANTA BARBARA

\author{
PRESENTED BY \\ MRS. NELLIE R. PREUSS
}




BY CHARLES S. NEWHALL

I.

THE TREES OF NORTHEASTERN AMERICA.

II.

THE SHRUBS OF NORTHEASTERN AMERICA.

III.

THE VINES OF NORTHEASTERN AMERICA.

IV.

THE LEAF-COLLECTOR'S HANDBOOK AND HERBARIUM. 


\title{
THE VINES
}

OF

\section{NORTHEASTERN AMERICA}

\author{
FULLY ILLUSTRATED FROM ORIGINAL SKETCHES
}

BY

CHARLES S. NEWHALL

Author of "The Trees of Northeastern America," "The Shrubs of Northeastern America," etc.

䅴

G. P. PUTNAM'S SONS

The ginickerbocker gress 
Copyright, 1897

BY

G. P. PUTNAM'S SONS

Entered at Stationers' Hall, London 


\section{THE VINES.}

Frail things, fair things, that creep and climb

With seeming sense of rhythm and rhyme,

That sometimes humbly keep the ground With bloom more sweet than elsewhere found,

Yet sometimes climb where breezes blow, And robins build and come and go,

You seem to bid men aim like you

For skyward things; or (if, though true,

They fail to rise, as some men must),

To live their best, like you, and trust,-

You weird, frail things that lean and climb, And all but speak with sense and rhyme. 


\section{CONTENTS.}

The Vines

List of Illuestrations Preface .

List of Families and of Genera . . . . xiii Directions, Signs Used, etc. $\quad . \quad$. . xvii Guide to the Vines-(by Flower) . . xix

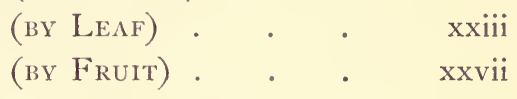

Descriptions of Vines (with Illustrations). Series A-Flowering Plants . . . I-I84 Class First (Exogens) . . . . $\quad$ I-I68 Mostly with Distinct Petals . . I-84 Mostiy with United Petals . $\quad 85^{-1} 54$ Mostly with Petals Lacking . . I55-i 68 Class Second (Endogens) . . . 169-184 Series B-Flowerless Plants . . . 185-196 Class Third (Acrogens). . . . $185-196$ Explanation of Terms . . . . 197-20 I Glossary . . . . . . . . 202 Index to the Vines . . . . . 203-207 



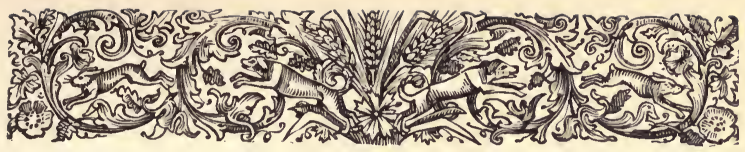

\section{ILLUSTRATIONS.}

Figure I.-VIRGIN'S-BowER,

Figure 2.-Leather-Flower,

Figure 3.-Whorled Clematis,

Figure 4.-MoOnSEed,

Figure 5.-Mountain Fringe,

Figure 6.-BitTER-SwEET,
Clematis Virginiana, $L . \quad 5$

Clematis Viorna, L. . 7

Clematis verticillaris, D. C. 9

Menispermum Canadense, $L$. I I

Adlumia fungosa, Green I3

Celastrus scandens, $L$. I5

Figure 7.-Trailing Strawberry-Bush, Euonymous obovatus, Nutt. I5

Figure 8.-NORTHERN Fox-Grape,

Vitis labrusca, $L . \quad 2 \mathrm{I}$

Figure 9.-SUMMer Grape,

Vitis astivalis, $M x$. $\quad 23$

Figure IO.-FROST-GRAPE,

Figure II.-RIVER-GRAPE,

Vitis cordifolia, $M x$. 25

Vitis vulpina, L. 27

Vitis palmata, Vahl. 29

Vitis rotundifolia, $M x$. $\quad 3 \mathbf{I}$

Figure 13.-SOUthern Fox-Grape, Ampelopsis quinquefolia, $M x . \quad 33$

Figure I4.-VIRGINIA CREEPER

Rhus radicans, $L . \quad 35$

Figure 15.-Poison-Ivy,

Figure I6.-Smoотн Bush-TREFoIL, Desmodium humifusum, Beck. 39

Figure I7.-Bush-TREFOIL,

Desmodium rotundifolium, D.C. $4 \mathrm{I}$

Figure I8.-Bush-Clover,

Lespedeza procumbens, $M x$. $\quad 4 \mathrm{I}$

Figure 19.-KIDney-BEAN, Phaseolus polystachyus (L.), B. S. P.

Figure 20.-Various-Leaved Kidney-Bean, Phaseolus helvolus, $L$. 45

Figure 2I.-UMBELled Kidney-Bean,

Phaseolus umbellatus (Muhl.), Britton

Figure 22.-FEW-Flowered Kidney-BeAN,

Phaseolus pauciforus, Benth.

Figure 23.-Butterfly-Pea, Clitoria Mariana, $L . \quad 5$ I

Figure 24.-HoG-PEANut,

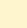

9

I

3

5

5

I

3

7

9

I

33

5

I

II

43


Figure 25--MILK-PEA,

Figure 26.-Ground-Nut,

Figure 27.-Common Vetch,

Figure 28.-Four-Seeded Vetch,

Figure 29.-Tufted Vetch,

Figure 30.-Carolina Vetch,

Figure 31.-Anerican Vetch,

Figure 32.-BЕACH-PEA,

Figure 33.-Yellow-White Vetchling, Lathyrus ochroleucus, Hook.

Figure 34.-Veiny Vetchling,

Figure 35.-Swamp Vetchling,

Figure 36.-Spreading Vetchling,

Figure 37.-Low BlackBERRY,

Figure 38.-FALSE VIOLET,

Figure 39.-Cinquefoil,

Figure 40.-Climbing Rose,

Figure 4I.-PASSION-FLower,

Figure 42.-One-Seeded Bur-Cucumber,

Figure 43.-Wild Balsam-Apple, Micrampelis lobata (Mx.), Green

Figure 44.-TWIN-Flower,

Figure 45-Trumpet-Honeysuckle,

Figure 46.-Japanese-Honeysuckle,

Figure 47.-Small-Leaved Honeysuckle,

Figure 48.-PARTRIDGE-BERRY,

Figure 49.-Bedstraw,

Figure 50.-Rough Bedstraw,

Figure 51.-Sweet-Scented Bedstraw,

Figure 52.- Haiky Bedstraw,

Figure 53.-Climbing Hemp-Weed,

Figure 54.-Large Craneerry,

Figure 55.-CREEPING SNOWBerRy,

Figure 56.-BEARBERry,

Figure 57.-Trailing Arbutus,

Figure 58.-WintergreEn,

Figure 59.- PyXie,
Galactia regularis (L.), B. S. P. 53

Apios tuberosa, Moench. 55

Vicia sativa, $\quad 57$

Vicia tetrasperma, $L . \quad 59$

Vicia cracca, $L . \quad 6$ I

Vicia Caroliniana, Walt. $6 \mathrm{I}$

Vicia Americana, Muhl. $6_{3}$

Lathyrus maritimus, Bir. $\quad 6_{3}$

Lathyrus venosus, Muhl. $\quad 65$

Lathyrus palustris, L. $\quad 67$

Lathyrus pretensis, L. $\quad 67$

Rubus Canadensis, L. $7 \mathrm{I}$

Dalibarda repens, L. 73

Potentilla Canadensis, L. 73

Rose setigera, Mx. $\quad 75$

Passiftora lutca, L. $\quad 75$

Sicyos angulatus, L. 79

Linnaa borealis, L. $\quad 89$

Lonicera sempervirens, Ait. $9 \mathrm{I}$

Lonicera Faponica, T. 93

Lonicera glanca, Hill 95

Mitchella repens, $L . \quad 97$

Galium aparine, L. 99

Galium asprellum, Mx. 99

Galium triflorum, Mx. $\quad \mathrm{I} 03$

Galium pilosum, Ait. $\quad \mathrm{IO} 3$

Mikania scandens, L. $\quad 105$

Vaccinium macrocarpon, Ait. 107

Chiogenes serpyllifolia, Salisb. Iо7 Arctostaphylos Uva-ursi, Spreng. II I

Epigrea repens, $L$. II 5

Gaultheria procumbens, $L$. II 9

Pyxidanthera barbulata, $M x$. I 23 
Figure 60.-MONEYWORT,

Lysimachia nummularia, $L$. I 25

Figure 6r.-Black Milkweed,

Vincetoxicum nigrum, Moench. I 25

Figure 62.-Rough-Fruited Milkweed,

Gonolobus obliquus, Moench. $\quad$ I 29

Figure 63.-MORNING-GLORY, Ipomaa purpurea, Lam. I 3 I

Figure 64.-Small Morning-Glory, Figure 65.-Wild CyPREss-Vine, Figure 66.-Hedge Bindweed, Figure 67.-Field Convolvulus, Figure 68.-BREWERIA, Figure 69.-DODDER, Figure 70.-Woody Night-Shade, Figure 7 1.-MATRIMONY-Vine, Figure 72.-Trumpet-Creeper, Figure 73.-Gill-over-THE-Ground, Ipomaa hederacea, Facy. $\quad 133$ Ipomara coccinea, $L . \quad \mathrm{I} 33$ Convolvulus sepium, $L . \quad \mathrm{I} 35$ Convolvulus arvensis, $L . \quad 137$ Breweria Pickeringii, G. I4 $\mathrm{I}$ Cuscuta Gronovii, Wild. I4 I Sslanum dulcamara, $L . \quad \mathrm{I} 47$ Lycium vulgare, Dunal. $\quad$ I 49 Tecoma radicans, Fuss. 149 Nepeta Glechoma, Benth. 153 Figure 74.-Halberd-Leaved Tear-Thumb,

Polygonum arifolium, L. 159

Figure 75.-Arrow-Leaved Tear-Thumb, Polygonum sagittatum, $L . \quad 159$ Figure 76.-BLACK BINDWEED, Polygonum convolvulus, $L$. I6I Figure 77.-Bristly-Jointed Bindweed, Polygonum cilinade, $M x$. $16 \mathrm{I}$ Figure 78.-HEDGE BindweEd, Polygonum scandens, $L . \quad$ I6 $\mathrm{I}$ Figure 79.-Pipe-Vine, Figure 80.-Hop, Figure 8I.-CARRION-FLOWER, Aristolochia Sipho, L' Her. 165 I/umulus Lupulus, L. $\quad{ }^{6} 67$ Smilax herbacea, $L . \quad 175$ Figure 82.-Yellowish Carrion-Flower, Smilax tamnifolia, $M x$. I 75 Figure 83.-CAT-BRIER, Figure 84.-FAlse Sarsaparilla, Figure 85.-STRETCH-BERRY, Figure 86.-False China-Brier, Figure 87.-Laurel-Leaved Smilax, Smilax rotundifolia, $L . \quad$ I 77 Smilax glauca, Walt. $\quad$ I 77 Smilax bona-nox, $L . \quad$ I 79 Smilax Pseudo-China, L. $\quad 183$ Figure 88.-Climbing Fern, Snilax laurifolia, $L . \quad \mathrm{I} 83$ Figure 89.-Interrupted Club-Moss, Figure 90.-Сомmon Club-Moss, Lygodium palmatum, Swartz 187 Lycopodium annotinum, $L . \quad$ I 89 Lyropodium clavatum, $L$. I9I Figure 9I.-Northern GROUND-PiNe, Lycopodium complanatum, L. I93 



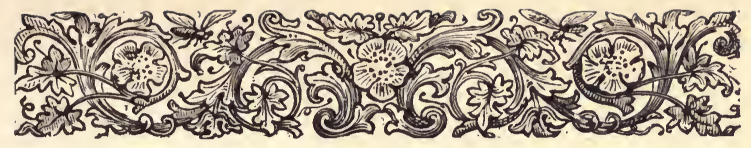

PREFACE.

I.

Possibly the opinion of some would be that this volume of the series deals with a subject less interesting than that of the first volume, on the Trees, and of the second volume, on the Shrubs. I doubt if such judgment would be deserved. There are too many names among the vines that are of high repute for one or another of various qualities ; witness, for uniqueness, the Dodder, with its tangle of yellow threads, and Pyxie; for meanness, the PoisonIvy; for lovableness, the Trailing Arbutus ; for old-time friendliness, Morning-Glories.

Moreover in even larger measure than the trees and the shrubs, the vines have a personality of their own. Once recognize a species, and it can seldom be confused with another, so varied are the postures (prostrate, reclining, climbing) and the methods of climbing (by help of tendril, of rootlet, of disk, of downward pointing prickles and hairs), besides the ordinary differences of foliage and flower and fruit. The vines are all characters, even cranks, some of them; and the better we know them, the more of individuality they seem to have; and with it all, the better we like them. 
II.

All the native and escaped vines found in Canada and the northern United States (east of the line of the Mississippi River, and north of the line of the southern boundary of Pennsylvania) are described in the following pages; and all are pictured, in natural size, excepting in a few cases where the close resemblance to other forms makes repetition unnecessary.

The three guides-for flower, and leaf, and fruit-will be readily understood, and will make identification in most cases easy.

Technical terms are avoided, as far as possible.

I have reason again to thank Dr. N. S. Britton, Emeritus Professor in Columbia University and Director of the New York Botanical Garden, for valuable aid and suggestion.

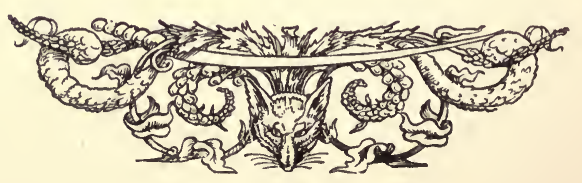




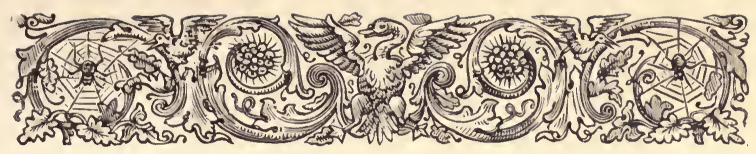

\section{LIST OF FAMILIES AND OF GENERA.}

Family i. Ranunculàcee (Crowfoot Genus Clématis, L. (CleFam.)

Family 2. Menispermàcefe (Moonseed Fam.)

Family 3. Fumariàcee (Fumitory Fam.)

Family 4. Celastràce£ (Staff-Tree Fam.)

matis).

Genus Menispérmum, L. (Moonseed).

Genus Adlùmia, Raf.(Mountain-Fringe).

Genus Celástrus, L. (BitterSweet).

Genus Euónymus, Tourn. (Tralling StrawberryBush).

Family 5. VitàceÆ (Vine Fam.)

Genus Vitis, Tourn. (The Grape).

Genus Ampelópsis, Mx. (Virginia Creeper).

Family 6. Anacardiàcex (Sumach Genus Rhus, L. (PoisonFam.)

Family 7. Leguminòsæ (Pulse Fam.) Ivy).

Genus Desmòdium, Desv. (Bush-Trefoil).

Genus Lespedèza, Mx. (Bush-Clover).

Genus Phasèolus, Tourn. (Kidney-Bean).

Genus Clitòria, L. (Butterfly-Pea).

Genus Amphicarpæa, Ell. (Hog-Peanut).

Genus Galáctia, P. Browne (Milk Pea).

Genus Ápios, Boer. (GroundNut). 


\section{xiv List of Families and of Genera.}

Family 7. Leguminóses (Pulse Fam.)

Family 8. RosÀCEe (Rose Fam).
Genus Vícia, Tourn.(Vetch).

Genus Láthyrus, Tourn.

(Beach-Pea).

Genus Rùbus, Tourn.(Blackberry, etc.).

Genus Dalibárda, L. (False Violet).

Genus Potentílla, L.(Cinquefoil).

Genus Ròsa, Tourn. (Rose).

Family 9. Passifloráce瓜 (Passion- Genus Passifòra, L. (PasFlower Fam.)

Family ro. Cucurbitàce e (Gourd Fam.) sion-Flower).

Genus Sícyos, L. (Bur-Cucumber).

Genus Micrámpelis, Mx. (Balsam-Apple).

Family ri. CAPrifoliàcee (Honey- Genus Linnæa, Gronov. suckle Fam.)

(Twin-Flower).

Genus Lonicèra, L. (Honeysuckle).

Family 12. Rubiàcex (Madder Fam.) Genus Mitchélla, L. (Partridge-Berry).

Genus Gàlium, L. (Bedstraw).

Family 13. Compósite (Composite Genus Mikània Wild.(ClimbFam.)

Family 14. ERICÀCE E (Heath Fam.) ing Hemp-Weed).

Genus Vaccínium, L. (Cranberry).

Genus Chiógenes, Salisb. (Creeping Snowberry).

Genus Arctostáphylos, Adans. (Bearberry).

Genus Epigæa, L. (Trailing Arbutus).

Genus Gaulthèria, Kalm. (Creeping Wintergreen).

Family 15. Diapensiàcex (Pyxie Fam.) Genus Pyxidanthèra, Mx. (Pyxie).

Family r6. Primulàcex (Primrose Genus Lysimàchia, Tourn. Fam.)

(Moneywort).

Family i7. Asclepiadàcee (Milkweed Genus Períploca, L. (TwinFam.) ing Milkweed). 


\section{List of Families and of Genera.}

Family 17. Asclepiadìcee (Milkweed Fam.)
Genus Vincetóxicum, Moench. (Black Milkweed).

Genus Gonólobus, Mx. (Rough-Fruited Milkweed).

Family i 8. Convolvulàcee (Convol- Genus Ipomùa, L. (Mornvulus Fam.)
Genus Convólvulus, Tourn.

(Bindweed).

Genus Brewèria, R. Br. (Breweria).

Genus Cúscuta, Tourn.

(Dodder).

Genus Solànum, Tourn. (Woody Nightshade).

Genus Lýcium, L. (Matrimony-Vine).

Family 20. BignoniàceÆ (Bignonia Fam.)

Family 21. Labiàte (Mint Fam.)

Family 22. Polygonàcex (Buckwheat Fam.)

Family 23. ARISTOLOCHIÀce无 (Birthwort Fam.)

Family 24. URTiCÀce出 (Nettle Fam.)

Family 25. LiLı̀̀cee (Lily Fam.)

Family 26. Fflices (Fern Fam.)

Family 27. Lycopodiàce (Club-Moss Fam.) enus Técoma, Juss. (Trumpet-Creeper).

Genus Népeta L. (Gill-overthe-Ground).

Genus Polýgonum, Tourn. (Knotweed).

Genus Aristolòchia, Tourn. (Pipe-Vine).

Genus Hùmulus, L. (Common Hop).

Genus Smilax, Tourn. (Greenbrier).

Genus Lygòdium, Swartz. (Climbing Fern).

Genus Lycopòdium, L. (Club-Moss).

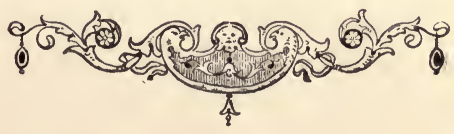





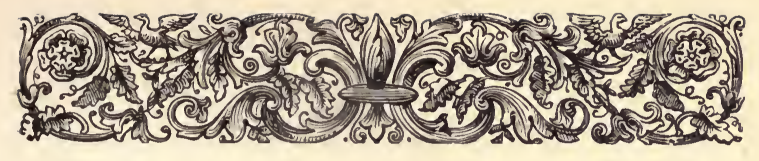

DIRECTIONS, SIGNS USED, ETC.

Note I.-The place of any given specimen can be readily found by help of one or more of the three "Guides" given on pages xix-xxx. The first Guide is arranged for use with the flowers; the second, with the leaves ; the third, with the fruit. Which of the three can be used to best advantage will depend on the time of year.

The descriptions are scientific but not technical.

Note 2.- In describing a species, the general items that have been given under the genus or the family to which the species belongs are not usually repeated.

Note 3.-Signs used: A grave accent ( $($ ) over a vowel indicates that it is accented and long. An acute accent ( ) over a vowel indicates that it is accented and short.

Note 4. -Names enclosed in brackets indicate that the vine is not native.

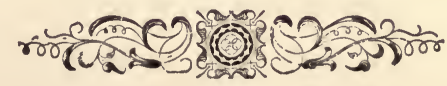





\section{GUIDE I.}

FLOWERS.

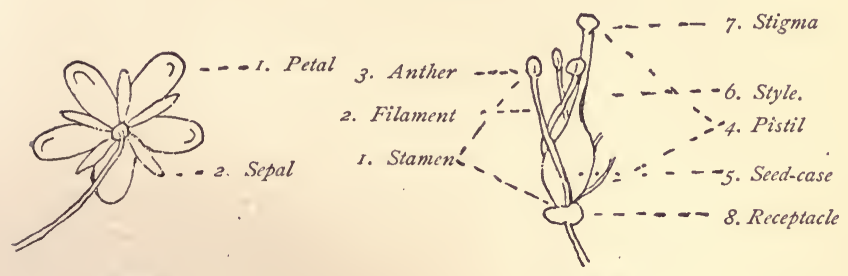

Fig. a.

Fig. b.

Series A. - Vines producing real flowers and seeds (Phænógamous plants).

Class First.-Flowers, with the parts never in threes (usually in fours or fives). Leaves netted-veined (Éxogens).

Division I. Sepals and petals both present, the latter not united into one piece (Polypétalous).

A. Stamens, numerous, at least more than ten. Sepals not attached to the seed-case or cases.

(a) Seed-cases, numerous, separate, concealed in an urn-shaped or cup-shaped receptacle. The Rose in Rose Fam. No. 8 (Rosàceæ), page 74 .

(a) Seed-cases, more than one, separate, not enclosed in the receptacle.

(b) Stamens inserted on the edge of a disk that lines the tube of the calyx. Flowers perfect. Rose Fam. No. 8 (Rosàceæ), page 68. 
(b) Stamens inserted on the receptacle. Flowers diœcious. (i.e., staminate and pistillate forms on separate plants). Moonseed Fam. No. 2 (Menispermàceæ), page 8.

B. Stamens of the same number as the petals and opposite them. Vine Fam No. 5 (Vitàceæ), page 16.

C. Stamens not more than twice as many as the petals; when of the same number, alternate with them.

I. Sepals not attached to the seed-case (i.e., the seed-case free). (a) Seed-case with one cell.

(b) Seed, one; flowers regular, greenish. Sumach Fam. No. 6 (Anacardiàceæ), page 34 .

(b) Seed, one ; flowers irregular, purplish. Lespedèza in Pulse Fam. No. 7 (Leguminòsæ), page 40.

(b) Seeds, two to many, attached in one row along the side of the cell; flowers irregular. Pulse Fam. No. 7 (Leguminòsæ), page $3^{6}$.

(b) Seeds many, not attached in one row along the side of the cell ; flowers regular. Passion Flower Fam. No. 9 (Passifloràceæ), page 76 .

(a) Seed-case with more than one cell. Staff-Tree Fam. No. 4 (Celastràceæ) page $\mathbf{1} 4$.

2. Sepals attached to the seed-case (i.e., the seed-case not free).

(a) Tendrils present. Gourd Fam. No. Iо (Cucurbitàceæ), page 78 .

(a) Tendrils lacking. Staff-Tree Fam. No. 4 (Celastràceæ), page 14.

Division II. Sepals and petals both present, the latter more or less united into one piece (Gamopétalous).

A. Stamens more numerous than the united petals. Fumitory Fam. No. 3 (Fumariàceæ) page $\mathbf{I} 2$.

B. Stamens of the same number as the united petals and opposite them. Primrose Fam. No. 16 (Primulàceæ), page 122.

C. Stamens of the same number as the united petals and alternate with them, or fewer.

I. Sepals attached to the seed-case.

(a) Tendrils present. Gourd Family No. Io (Cucurbitàceæ), page 78 .

(a) Tendrils lacking.

(b) Stamens with anthers united around the style. Composite Fam. No. 13 (Compósitæ), page 102.

(b) Stamens with anthers not united. 
(c) Petals, four, united. Madder Fam. No. I2 (Rubiàceæ) page 96 .

(c) Petals, five, united. Honeysuckle Fam. No. I I (Capri foliàceæ), page 87 .

2. Sepals not attached to the seed-case.

(a) Corolla irregular.

(b) Prostrate; flowers blue. Gill-over-the-Ground in Mint Fam. No. 2 I (Labiàtæ), page 152.

(b) Climbing; flowers scarlet. Trumpet-Creeper in Bignonia

(a) Corolla regular.

Fam. No. 20 (Bignoniàceæ), page $15 \mathrm{r}$.

(b) Stamens of the same number as the united petals.

(c) Seed-cases, two; separate. Milkweed Fam. No.

(c) Seed-case one.

I 7 (Asclepiadàceæ), page I 24.

(a) Stamens free from the corolla, but inserted with its base. Heath Fam. No. 14 (Ericàceæ), page ıo6.

(d) Stamens adherent by their sides to the tube of the corolla. Pyxie Fam. No. 15 (Diapensiàceæ), page I 2 I.

(d) Stamens adherent by their bases to the tube of the corolla.

(e) Seeds few, one or two in each cell. Morning-Glory Fam. No. 18 (Convolvulàceæ), page 127.

(e) Seeds, many. Nightshade Fam. No. I9 (Solanàceæ), page 146.

Division III. Petals wanting (Apétalous).

(a) Seed-case, one, attached to the sepals. Pipe-Vine in Birthwort Fam. No. 23 (Aristolochiàceæ), page 163.

(a) Seed-case, one, free from the sepals.

(b) Leaves alternate. Buckwheat Fam. No. 22 (Polygonàceæ), page 157 .

(b) Leaves opposite. Hop in Nettle Fam. No. 24 (Urticàceæ), page 164 .

(a) Seed-cases, numerous, with single seeds (achenes). Clematis in Crowfoot Fam. No. I (Ranunculàceæ), page 4.

Class Second.-Flowers, with the sepals and the petals never in fives-usually in threes. Leaves strongly veined from base to apex, the veins more or less 
nearly parallel (Éndogens). Smilax in Lily Fam. No. 25 (Liliàceæ) I 73

Series B.-Vines producing in place of real flowers and seeds, yellow dust-like spores in minute spore-cases (Cryptógamous plants).

(a) Spore-cases borne on the back of the leaf. Climbing Fern in Fern Fam. No. 26 (Filices), page 186.

(a) Spore-cases in spikes solitary at the base of the small, evergreen leaves, low moss-like plants. Lycopodium in Club-Moss Fam. No. 27 (Lycopodiàceæ), page 186.

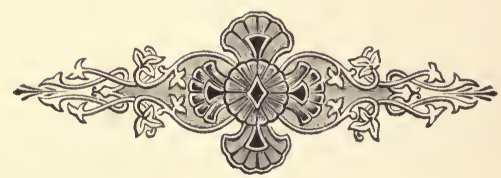




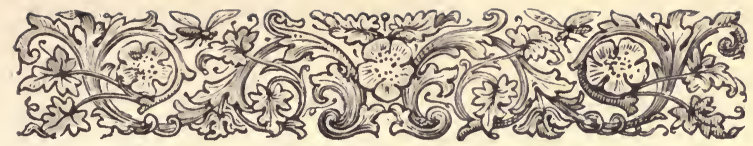

\section{GUIDE II.}

LEAVES.

A. Leaves simple.*

I. Alternate.

(a) Edge entire. Go to I.

(a) " toothed. Go to 2.

(a) " lobed.

(b) Lobes entire. Go to 3 .

(b) " toothed. Go to 4 .

II. Opposite.

(a) Edge entire. Go to 5 .

(a) " toothed. Go to 6 .

(a) " lobed.

(b) Lobes entire. Go to 7 .

(b) " toothed. Go to 8.

III. Indeterminate (because of smallness or closeness). Go to 9 .

B. Leaves compound.

(a) Alternate.

(b) Edge of leaflets entire. Go to. ro.

(b). " " toothed or lobed. Go to II.

(a) Opposite.

(b) Edge of leaflets entire. Go to $\mathbf{r 2 .}$

(b) " " toothed or lobed. Go to $\mathbf{r} 3$.

C. Leaves lacking or represented by minute and remote scales. Go to 14 .

* The leaflets of a compound leaf can be distinguished from a simple leaf by the absence of leaf-buds from the base of their stems. 


\section{GUIDE II.}

\section{LEAVES-Continued.}

Note.-Names in italics are also given elsewhere in roman type under the more frequent form.

Grapes (Vìtis), climbing with tendrils, page 20.

Smilax (Smilax), climbing with tendrils, page 171 .

Moonseed (Menispérmum), climbing without tendrils, page 8 .

Woody Nightshade (Solànum), climbing without tendrils, page 146.

Pipe-Vine (Aristolòchia), climbing without tendrils, page ${ }_{1} 6_{3}$.

Climbing Fern (Lygòdium), climbing without tendrils, page 183 .

Convolvulus Fam. (Convolvulàceæ), climbing without tendrils, or prostrate, page I 27.

Knot-Weeds (Polýgonum), climbing without tendrils, or prostrate, page I57.

Heath Fam. (Ericàceæ), prostrate, page ro6.

Pyxie (Pyxidanthèra), prostrate, page 121.

Matrimony Vine (Lýcium), branches trailing, stem erect, page 148 .

2

Grapes (Vìtis), climbing with tendrils, page 20.

Sinilax (Smilax), climbing with tendrils, page $\mathbf{1} 71$.

Bitter-Sweet (Celástrus), climbing without tendrils, page I4.
False Violet (Dalibárda), prostrate, page 72 .

3

Grapes (Vitis), climbing with tendrils, page 70.

Passion-Flower (Passiflora), climbing with tendrils, page 76 .

Smilax (Smilax), climbing with tendrils, page $17 \mathbf{I}$

Moonseed (Menispérmum), climbing without tendrils, page 8 .

Woody Nightshade (Solànum), climbing without tendrils, or prostrate, page 146.

Convolvulus Fam.(Convolvulàceæ), climbing without tendrils, or prostrate, page 127 .

\section{4}

Grapes (Vitis), climbing with tendrils, page 20 .

Gourd Fam.(Cucurbitàceæ), climbing with tendrils, page 78 .

Hedge Bindweed (Convolvulus), climbing without tendrils, or prostrate, page 136 .

\section{5}

Honeysuckle Fam. (Caprifoliàceæ), without tendrils, twining, page 87 .

Bedstraw (Gàlium), without tendrils, climbing by prickles, page 98 . 
Climbing Hemp-IVeed (Mikània), climbing without tendrils, page 102.

Milkweeds (Asclepiadàceæ), climbing without tendrils, or prostrate, page I 24.

Truin Flower (Linnæa), prostrate and rooting, page 87 .

Partridge-Berry (Mitchélla), prostrate, page 96 .

Moneywort (Lysimàchia), prostrate, page 122.

\section{6}

Climbing Hemp-Weed (Mikània), climbing without tendrils, page I02.

Trailing Strawberry-Bush (Euónymus), drooping or trailing, and rooting, page $\mathbf{r} 6$.

Twin-Flower (Linnæa), prostrate and rooting, page 87 .

Gill-over-the-Ground prostrate, page ${ }_{1} 5^{2}$.

\section{7}

8

\section{9}

(Népeta),

7

\section{8}

\section{9}

Club-Mosses (Lycopòdium), page I 86.

Io

Poison-Ivy (Rhus), climbing with rootlets, page 34 .

Vetches and Vetchlings (Vícia and Láthyrus), climbing with tendrils at the end of the leaves, pages 56,62 .
Ground-Nuts (Ápios), twining, no tendrils, page 54 .

Butterfly-Pea (Clitòria), climbing without tendrils, page 46 .

Hog-Peanuts (Amphicarpìa), climbing without tendrils, page 48.

Kidney-Beans (Phasèolus), twining or prostrate, no tendrils, page 40 .

Milk-Peas (Galáctia), twining, leaning, or prostrate, no tendrils, page $5^{2}$.

Bush-Trefoils (Desmòdium), prostrate, no tendrils, page $3^{8}$.

Bush-Clover (Lespedèza), prostrate, no tendrils, page 40.

I i

Mountain-Fringe (Adlùmia), climbing by its leaf-stems, page 12.

Virginia Creeper (Ampelópsis), climbing by tendrils with suckerlike tips, page 30.

Poison-Iry (Rhus), climbing by rootlets, page 34 .

Climbing Rose (Ròsa), climbing, without tendrils, page 68 .

Dwarf Raspberries and Blackberries (Rùbus), prostrate, page 69.

Cinquefoil (Potentílla), prostrate, page 72 .

I 2

Leather-Flower (Clématis), climbing by the interlocking of leafand leaflet-stems, page 6 .

Whorled Clematis (Clématis), climbing by the interlocking of leaf-and leaflet-stems, page 6 . 
I3

Virgin's-Bower (Clématis), climbing by the interlocking of leafand leaflet-stems, page 4 .

Leather-Flower (Clématis), climbing by the interlocking of leafand leaflet-stems, page 6 .
Whorled Clematis (Clématis), climbing by the interlocking of leaf- and leaflet-stems, page 6 .

Trumpet-Creeper (Tecoma), climbing by rootlets, page 15 I.

I 4

Dodder (Cúscuta), page 139 .

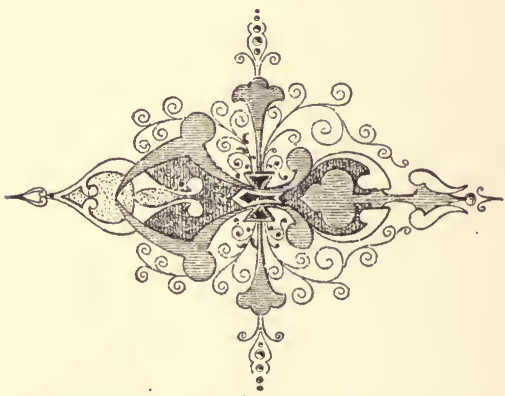




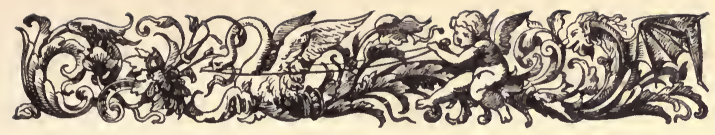

\title{
GUIDE III.
}

\author{
FRUIT.
}

Class I.-Fruit releasing the ripened stone or seed by decaying :

A. Fleshy or pulpy.

(a) With one stone, or with several firmly united into one (e.g., Moonseed). A drupe. Go to I).

(a) With two or more seeds-or in Bur-Cucumber, and sometimes in Smilax, with one.

(b) Fruit simple, not an aggregation.

(c) With a hard rind, melon-like (e.g., Bur-Cucumber). A pepo. Go to 2 .

(c) Without a hard rind (e. g., Grape, Wintergreen). A berry. Go to 3 .

(b) Fruit compound, an aggregation of one-seeded drupelets (e.g., Blackberry). An atæsio. Go to 4 .

B. Dry. A thin-coated seed, or aggregation of such seeds (e.g., Cinquefoil). Achenes, or nutlets. Go to 5 .

CLass II.-Fruit releasing the ripened seeds by splitting:

(a) Pod, splitting along one side, one-celled, with many crowded, silky seeds (e.g., Milkweeds). A follicle. Go to 6 .

(a) Pod, splitting along two sides, one-celled, with one seed, or with many attached along one of the seams (e.g., Pea). A legume. Go to 7 .

(a) Pod, jointed, splitting across at the joints, each section with one seed (e.g., Bush-Trefoils). Go to 8.

(a) Any form of fruit that splits up and down and is not otherwise named (e. $g$., Morning-Glory). A capsule. Go to 9 . 
Class III.-Fruit, minute cases filled with dust-like spores :

(a) Fruit on the back of the leaf, or frond (e.g., ClimbingFern). Go to ro.

(a) Fruit in spikes (e.g., Club-Mosses). Go to I I.

Note.-Names in italics are also given elsewhere in roman type under the more frequent form.

I

Moonseed (Menispérmum), twining, page 8 .

Poisoll-Ivy (Rhus), climbing by rootlets, page 34 .

Bearberry (Arctostàphylos), prostrate, page 1 I 2.

2

One-seeded Bur-Cucumber (Sícyos), one seed, page 78 .

Wild Balsam-Apple (Micrámpelis), four seeds, page $8 \mathrm{r}$.

3

Grapes (Vìtis), tendrils forked, excepting in Southern Fox-Grape, page 20 .

Virginia Creeper (Ampelópsis), tendrils, adhering by disk-like tips, page 30 .

Passion-Flower (Passiflòra), tendrils, simple, page 76 .

Smilax (Smilax), tendrils, in pairs on the leaf-stem, page 171.

Woody Nightshade (Solànum), many-seeded, without tendrils, climbing, page 146 .

Honeysuckle (Lonicèra), severalseeded, leares opposite, without tendrils, climbing, page 88 .
Bitter-sweet (Celástrus), three- to six-seeded, leaves alternate, without tendrils, climbing, page 14 .

Partridge-Berry (Mitchélla), berry, red, eight-seeded; prostrate, page 96 .

Creeping-Wintergreen (G a u lthèria), berry, red, many-seeded; prostrate, page I 18 .

Bearberry (Arctostáphylos), berry, red, five united nutlets ; prostrate, page 112.

Cranberries (Vaccínium), berry, reddish, many-seeded; prostrate, page ro6.

Creeping Snowberry (Chiógenes), berry, white, many-seeded; prostrate, page IIo.

Matrimony Vine (Lýcium), branches trailing, stem erect, page 148 .

\section{4}

Dwarf Raspberry and Blackberries (Rùbus), page 69 .

False Violet (Dalibárda), nearly dry, page 72 .

\section{5}

Clematis (Clématis), achenes numerous, each with plume-like tail, page 3 . 


\section{Fruit.}

Cinquefoil (Potentílla), achenes numerous, smooth, page 72 .

Climbing Rose (Ròsa), achenes numerous, enclosed in a globular case, page 68.

Climbing Hemp-Weed (Mikània), achenes, four, each five-angled, page 102.

Gill-over-the-Ground (Népeta), achenes four, slightly cohering, page 152 .

Bedstraws (Gàlium), achenes or nutlets two ; slightly cohering, page 98 .

Knotweeds (Polýgonum), achene one, flattened or three-angled, page ${ }^{5} 57$.

Hop (Hìmulus), achene one, covered by the thin calyx and yellow-dotted, with resinous grains, page 164 .

False Violet (Dalibárda), achenelike drupelets, five to ten, page 72.

\section{6}

Milkweeds page r 24 .

(Asclepiadàceæ), 7

Bush-Clover (Lespedèza), seeds one, page 40.

Vetches and Vetchlings (Vícia and Láthyrus), seeds, two to several; tendrils at the ends of the compound leaves, pages 56,62 .

Butterfly-Pea (Clitòria), seeds, three to four; pod, knotty and somewhat flattened, page $4^{6}$.

Hog-Peanuts(Amphicarpæaa), pods of two kinds : the upper, three- to four-seeded ; the lower (mostly underground), usually oneseeded, page 48 .

Milk-Peas (Galáctia), seeds, four to ten; pod, downy, becoming smoothish, or very hairy; slender and flat, page 52 .

Kidney-Bean (Phaséolus), seeds, four to ten, kidney-shape, oblong with blunt ends, or foursided, flattened, page 40.

Ground-nut (Ápios), seeds, many, black; pod, nearly cylindrical, page 54 .

\section{8}

Bush-Trefoils (Desmódium), page 38.

\section{9}

Mountain Fringe (Adlùmia), onecelled; seeds, four to eight, page $\mathrm{r} 2$.

Moneywort (Nummulària), onecelled; seeds, few, page 122

Convolvulus Family (Convolvulàce.e), one- $t$, four-celled ; seeds, two to six, page I 27.

Trumpet-Creeper (Técoma), two: celled; seeds, very many, page $15 \mathrm{r}$.

Wild Balsam-Apple (Micrámpelis), two-celled; seeds, four, page 81.

Twin-Flower (Linnæ̀a), threecelled (two abortive); seeds, one, page 87 .

Bitter-Sweet (Celástrus), threecelled, scarlet lining; seeds, three to six, page 14 . 
Pyxie(Pyxidanthèra), three-celled; Pipe-Vine (Aristolòchia), sixseeds, many, page $\mathbf{2} 2 \mathrm{r}$.

Trailing Strawberry-Bush (Euónymus), five-celled, scarlet lining; seeds, few, page 16.

Trailing Arbutus (Epigæa), five-

celled; seeds, many, page II3. Lycopòdiums, page 187. celled; seeds, many, page I $63 ._{3}$

Climbing-Fern (Lygòdium), page 183 .

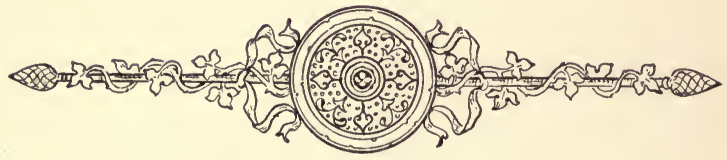




\section{DESCRIPTION OF VINES \\ (WITH ILLUSTRATIONS)}

\section{CLASS FIRST}

EXóGENOUS PLANTS (LEAVES USUALLY NETTED VEINED)

\section{DIVISION I}

CALYX AND COROLLA USUALLY BOTH PRESENT, THE LATTER OF SEPARATE' PETALS

(POLYPÉTALOUS) 



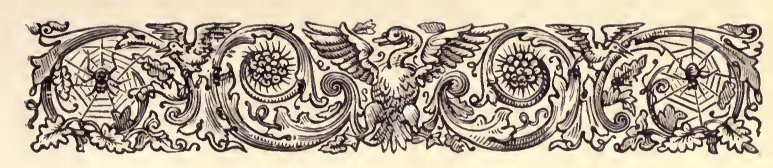

No. 1.-Family RANUNCULÀCEÆ. (Crowfoot Fam.)

\author{
Genus Clématis, L.
}

From a Greek word meaning a vine or tendril.

Flowers, rather large, excepting in No. I (Virgin's-Bower). Petals, none. Sepals, four, colored like petals. Stamens, very many, distinct, shorter than the sepals; attached beneath the seed-cases. Seed-cases, many in a head. Young seeds, one in each case.

Leaves, compound, or in Leather-Flower (C. Viorna), the upper ones sometimes simple; opposite, without stipules.

Fruit, ornamental and unique, a head of single seeds, each seed tipped with the greatly lengthened feathery or hairy style. Clustered achenes.

Woody, climbing vines (herbaceous in Leather-Flower, C. Viörna), supported by the twisting and interlocking of their leaf- and leaflet-stems. The juice is acrid. There is but one clematis native to England-the Traveller's Joy (C. vitálba).

Sometimes the movements of climbing plants are due to light, but in the clematis the curious interlocking of the stems is probably caused by the irritability of the 
parts as they touch. After a time they become stiff and thick.

"These plants have no use in Phisicke as yet found out, but are esteemed onely for pleasure, by reason of the goodly shadowe which they make with their thick bushing \& clyming, as also for the beauty of the flowers, \& the pleasant sent or savour of the same."-Gerard's Herball, London, I 597.

Fig. I.-(I) Virgin's-Bower. Clématis. C. Virginiàna, $L$.

Flowers, half to three quarters inch across, whitish, in loose-stemmed clusters from the axils of the leaves. Petals, lacking. Sepals, about one half inch long, thin, spreading, blunt, reverse egg-shape. Stamens, twenty-eight to thirty-six. Anthers, short and blunt. Staminate and pistillate forms on different plants. July, August.

Leaves, compound; opposite; stems two to three inches long, or more.

Leaflets, three, edges toothed and sometimes lobed, smooth, two to three inches in length, egg-shape. Apex, pointed. Base, usually somewhat heart-shape.

Fruit, furnished with long plumes in showy, downy tufts.

Found, common from Canada to Georgia and the Mississippi River, climbing vigorously over bushes and along walls and fences.

A woody, hardy vine, with stems from eight to fifteen feet in length. The plant is very ornamental, especially 


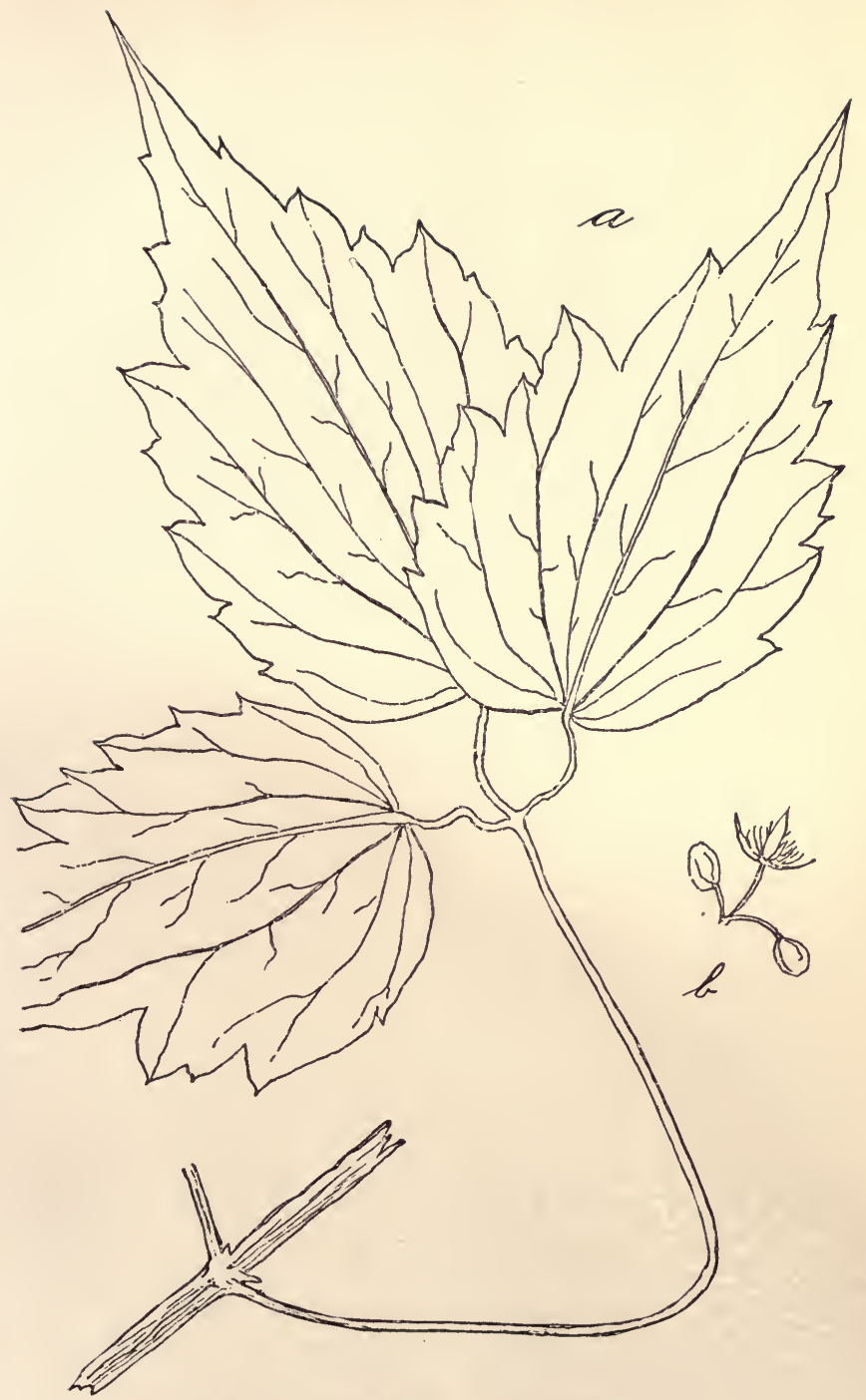

Fig. I.-Virgin's-Bower. (C. Virginiàna, L.) $a$. Leaf. $b$. Part of staminate flower-cluster. 
so in the fall by reason of its tufted fruit. It climbs by help of its twining and interlocking leaf- and leaflet-stems. It is one of the commonest vines for home cultivation, and one of the best.

\section{Fig. 2. -(2) Leather-Flower. C. Viórna, L.}

Flowers, large, solitary, dark purple, on long stems. Petals, lacking. Sepals, one inch long, very thick and leathery, cohering throughout or with the tips separated and turned back, long egg-shape, pointed. Stamens, many. Anthers, line-like. May to August.

Leaves, oftenest compound, the upper ones sometimes. simple and nearly stemless.

Leaflets, three to seven; two- to three-lobed or entire; smooth or nearly so; egg-shape or oblong. Base, sometimes slightly heart-shape.

Fruit, with plume-like tails one and one half inches in length.

Found, in rich soil, oftenest in woods, from Pennsylvania and Ohio to Georgia.

A climbing, herbaceous vine, with the stem slightly ridged and grooved, from ten to fifteen feet in length.

Fig. 3.-(3) Whorled Clématis. C. Verticillàris, D. C.; Atragene Americànus, Sims.

Flowers, two to three inches across, solitary, one from each pair of leaves, bluish-purple. Petals, lacking. Sepals, one and one quarter inches in length, thin, 


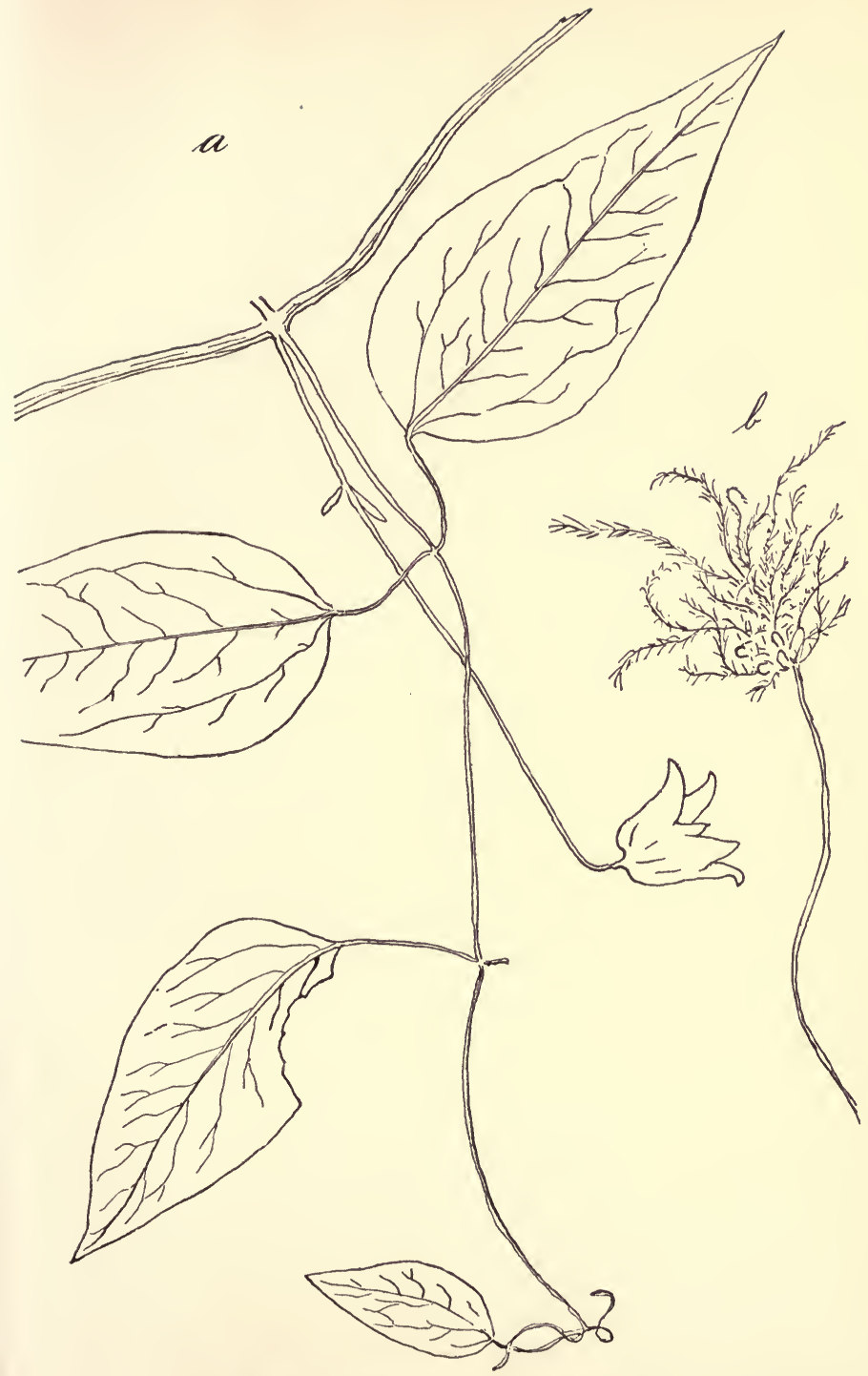

Fig. 2.-Leather-Flower. (C. Viónna, L.)

$a$. Leaf and flower. $b$. Fruit. 
widely spreading, not cohering, pointed, oblong to egg-shape. Stamens, about twenty-four, the outer ones widening, like imperfect petals, and tipped with imperfect anthers. Flower-stems and leaf-stems about equal in length. May.

Leaves, compound, opposite, often in pairs (giving the effect of a whorl of four leaves-whence the name), on slender stems.

Leaflets, three, one to two inches in length, egg-shape to slightly heart-shape, nearly smooth. Edge, entire or sparingly toothed or lobed. Apex, pointed.

Fruit, with long plume-like tails.

Found, in woods and rocky places from Virginia northward. Rare.

A handsome, woody-stemmed vine climbing by means of its twisting leaf-stems to a height of fifteen feet.

No. 2.-Family MENISPERMÀCEÆ.(Moonseed Fam.)

Genus Menispérmum, L.

From two Greek words meaning " moon" and " seed," because of the crescent form of the seed.

Fig. 4.-Moonseed. M. Canadénse, $L$.

Flowers, small, white, in loose clusters from the sides of the branches. Cluster-stem at the base of the leafstem, not, as in the grape-vine, opposite to it. Petals, small, six to eight, not united. Sepals, four to eight. Petals and sepals similar and in three or more 


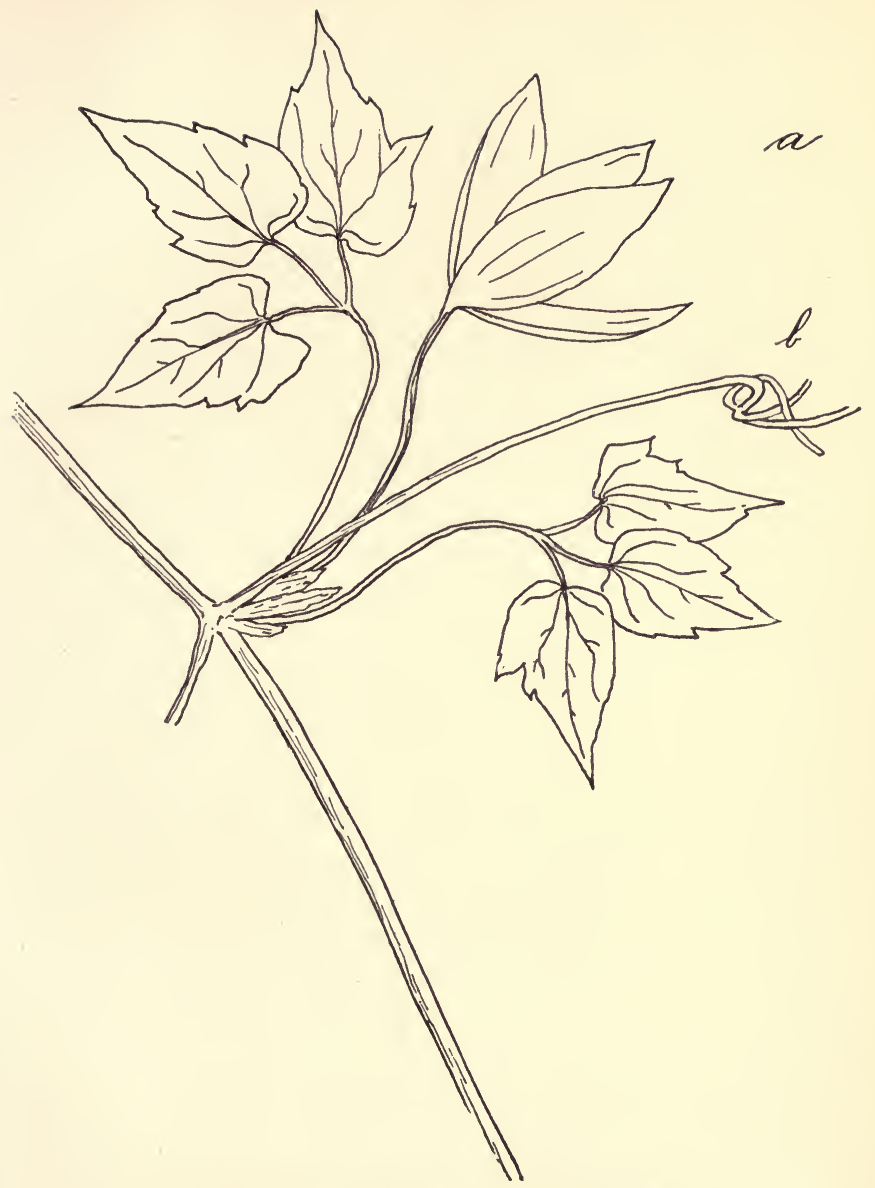

Fig. 3.-Whorled Clématis. (C. Verticillàris, D. C.)

9 a. Blossom and young leaves. b. Last year's leaf-stem with coiled leaflet-stems. 
rows. Staminate and pistillate flowers on separate plants. Stamens, twelve to twenty-four, slender, as long as the sepals. Anthers, four-celled. Seed-cases two to four, free, and raised on a short common receptacle. Seeds, one to three in each cell, crescentshaped and flattened. June, July.

Leaves, simple, alternate, three- to seven- (usually five-) angled or lobed, edges entire; four to five inches in diameter, heart-shape, smooth or nearly so ; the leafstem usually attached within the edge. No stipules. Leaf-stem, three to five inches in length.

Fruit, about one third inch in diameter, black, globular, fleshy, resembling a small grape. Stone, curved, flattened, grooved. A one-seeded drupe. September.

Found, from Canada to the Carolinas, and westward to the Mississippi River, oftenest along streams. Common.

A woody, twining vine, eight to twelve feet in length. Its root is used medicinally as a tonic. It might easily be mistaken at first sight for a grape-vine-until the position of the fruit- and flower-clusters is noticed, in the axil of the leaves instead of opposite them. 


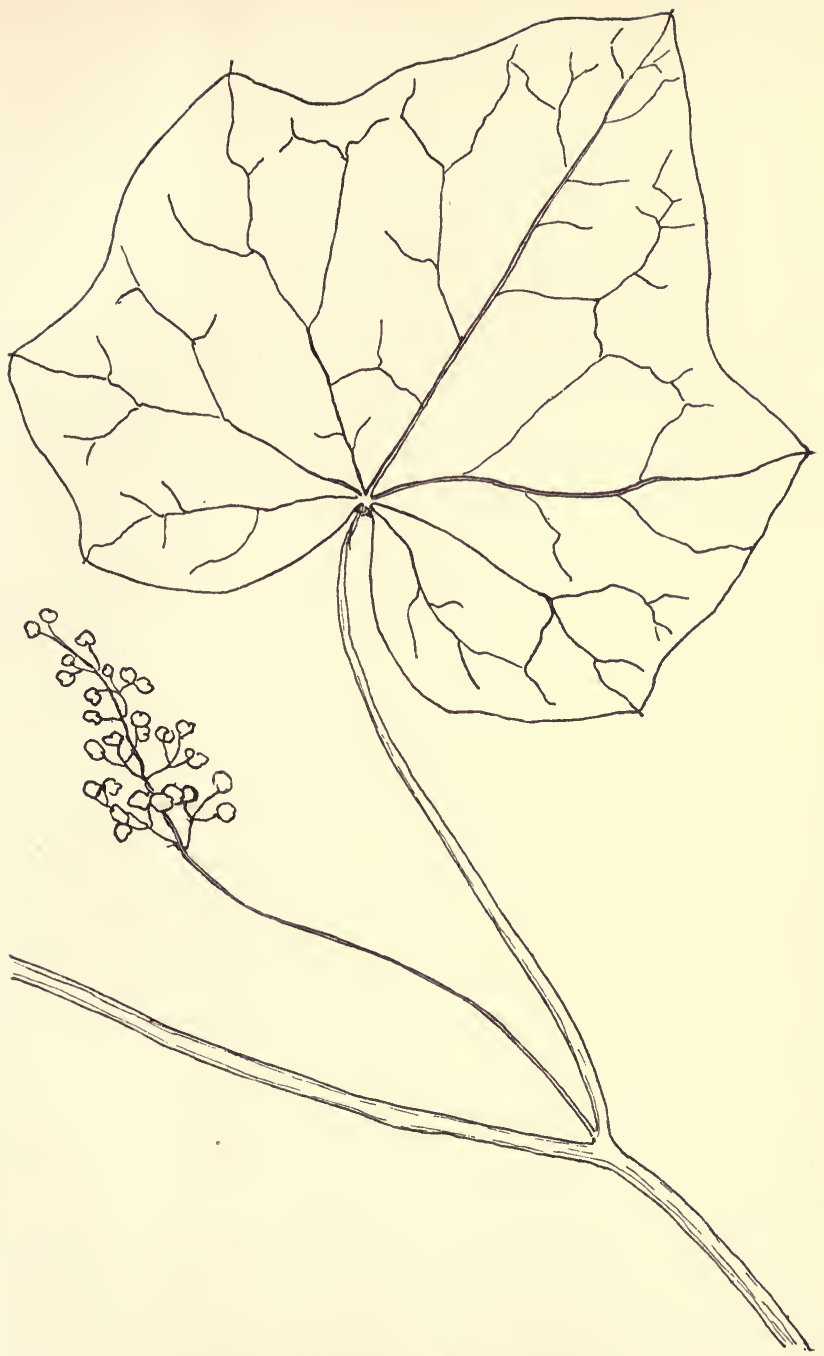

Fig. 4.-Moonseed. (M. Canadénse, L.) 
No. 3.-Family FUMARIÀCEÆ. (Fumitory Fam.)

Genus Adlùmia, Raf.

From the name of John Adlum, a cultivator of the vine in Washington, D. C.

Fig. 5.-Mountain-Fringe. Climbing Fumitory. A. fungdsa (Ait.), Green. A. cirrhosa, Raf.

Flowers, white or purplish, drooping, irregular, very numerous, in clusters. Petals, four, united in two pairs, the outer pair with spreading tips, the inner pair with the tips crested and joining over the stigma. Corolla, flattened, egg-shape, two-lipped at the summit, at the base somewhat heart-shaped. Sepals, two, minute, scale-like. Stamens, six, the lower parts of the filaments united into a tube which is joined to the corolla, the upper parts arranged in two sets. Style, slender. Stigma, two-crested. Seed-case, small, free, one-celled, four- to eight-seeded. June, October.

Leaves, twice compound, dividing in threes, alternate, without stipules. Leaflets, delicate, smooth, with their edges two- to three-lobed.

Fruit, oblong, four- to eight-seeded. Seeds, shining, kidney-shape. A capsule.

Found, in damp woods and over rocky hills from Canada to North Carolina, and westward. Often cultivated for ornament.

A delicate herbaceous vine, with watery and slightly bitter juice; a biennial, eight to fifteen feet in length; climbing extensively by help of its slender, tendril-like leaf-stems. 


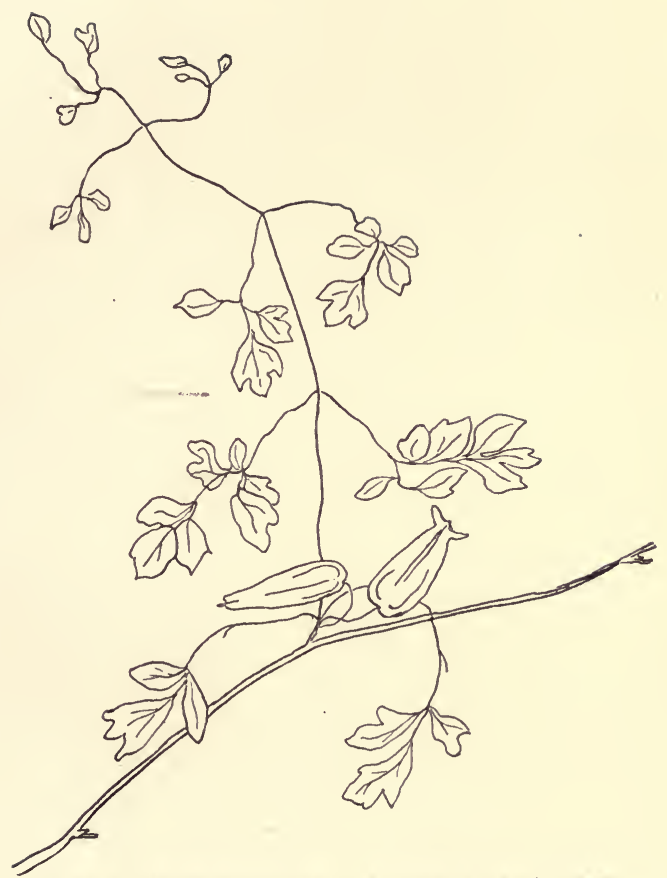

Fig. 5.-Mountain-Fringe. A. fungòsa (Ait.), Green.

13 
No. 4.-Family CELASTRÀCEÆ. (Staff-Tree Fam.)

\section{(I) Genus Celástrus, L.}

Fig. 6.-Bitter-Sweet. Wax-Work. Staff-Tree. C. scándens, $L$. Flowers, small, greenish, regular; in clusters at the ends of the branchlets; the staminate and the pistillate forms often on separate plants. Petals, five, distinct, spreading, inserted with the alternating stamens on the edge of the disk that lines the base of the calyx. Sepals, five, united, forming a cup-shaped calyx. Stamens, five. Style, thick. Seed-case, free, three-celled, three- to six-seeded. June.

Leaves, two to three and a half inches in length, simple, alternate, slightly fine-toothed, smooth, from eggshape and oblong to reverse egg-shape. Apex, pointed. Base, pointed or sometimes rounded. Stipules, minute and soon falling.

Fruit, about one third inch in diameter, round, orangecolor, three-celled, three- to six-seeded ; opening when ripe, and showing within a rich scarlet cover of the seeds. Seeds, oblong, reddish-brown, one or two in each cell. A berry-like capsule. September.

Found, oftenest along streams and over old walls and thickets, from North Carolina northward.

A strong woody climber, twining upon itself in coils and snarls, over fences and walls and bushes to great distances. Very showy in autumn and winter by reason of its brilliant orange and scarlet fruit.

This is one of the best of vines for decoration. In country homes it is in great demand, especially at the Christmas time. 

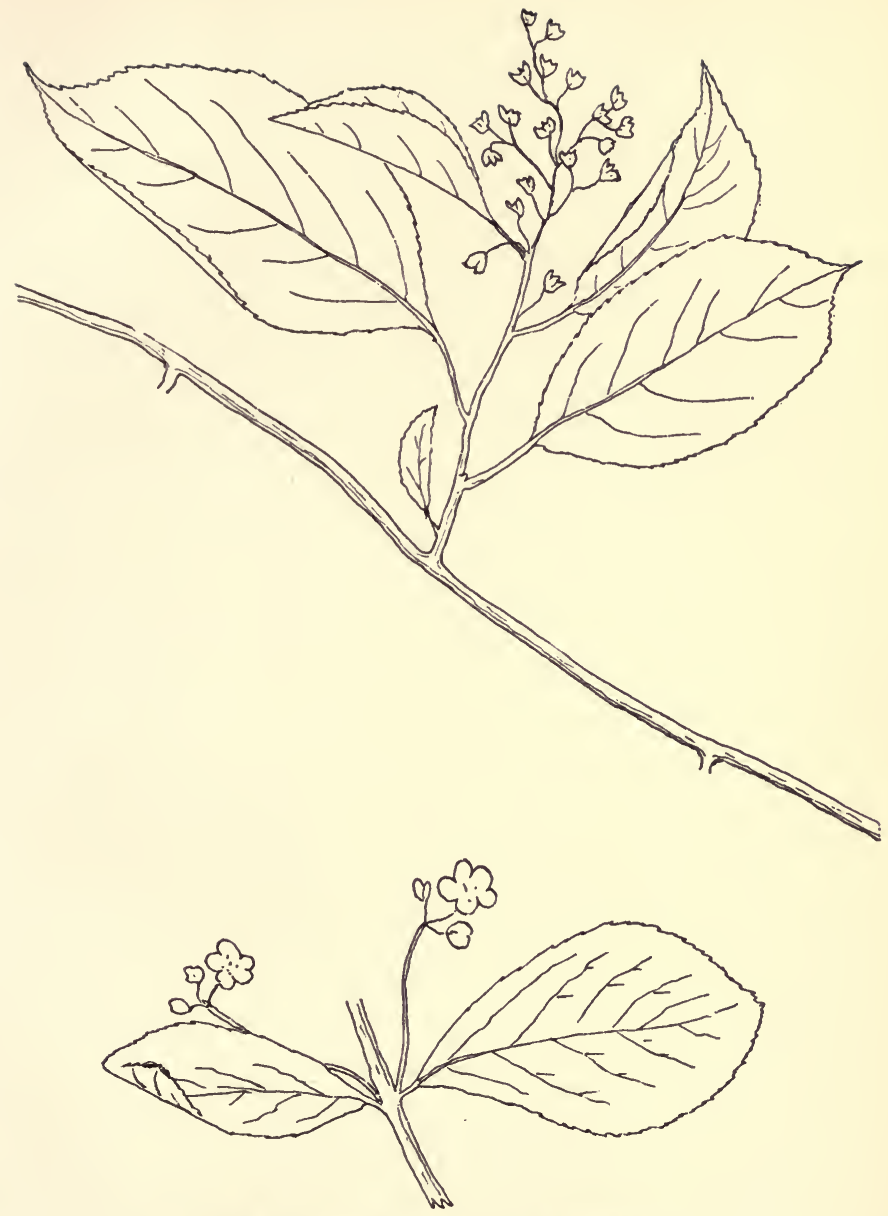

Fig. 6.-Bitter-Sweet. (C. scándens, L.)

Fig. 7.-Trailing Strawberry-Bush. (E. obovàtus, Nutt.) 
(2) Genus Euónymus, Tourn.

Fig. 7.-Trailing Strawberry-Bush. E. obovàtus, Nutt.

Flowers, flat, regular, about three blossoms on one long stem springing from the axils of the leaves. Petals, four or five (usually five), distinct, rounded. Sepals, four or five, united. Stamens, alternate with the petals and inserted with them on a disk which lines the base of the calyx and sometimes covers the seedcase. Filaments, short. Seed-case, three- to fivecelled, not adhering directly to the calyx, but more or less to the disk.

Leaves, about two inches in length, simple, opposite, toothed, reverse egg-shape to oblong. Apex, blunt or pointed. Base, pointed.

Branchlets, four-sided.

Fruit, five-lobed, splitting when ripe and showing within the scarlet cover of the seeds. Seeds, few. A capsule.

Found, in low, damp ground from New York, west and south.

A trailing or drooping woody vine rooting at the joints.

$$
\text { No. 5.-Family VITÀCE } Æ . \quad \text { (Vine Fam.) }
$$

Flowers, greenish, small, regular, in clusters opposite the leaves; pistillate and staminate forms often separate. Petals, four or five, distinct or cohering at the top, soon falling. Calyx, minute. Stamens, as many as the petals and opposite them, inserted on a disk which surrounds the seed-case. Filaments, slender, Seed-case, free, two-celled, usually four-seeded. Style, short or none. Stigma, slightly two-lobed. 
Leaves, simple in the genus Vitis (Grape), compound in the genus Ampelópsis (Virginia Creeper); alternate, the lower ones often opposite; edge various.

Fruit, one- or two-celled, usually four-seeded. Seeds, bony. A berry.

Woody vines, with watery juice and swollen joints; climbing by tendrils; the foliage and young shoots acid.

GUIDE TO GENERA.

Leaves simple-(1) Vìtis (Grape).

Leaves compound-(2) Ampelópsis (Virginia Creeper).

(I) Genus Vìtis, Tourn. (Grape.)

Flowers, in compound clusters, very fragrant. Petals, separating only at their base. The disk at the base of the seed-case set with five honey-glands alternating with the stamens.

Leaves, simple, rounded and heart-shaped. Edge, entire or variously lobed or toothed. Tendrils, forked.

Bark, loose and shredded (except in Southern Fox-Grape, V. rotundifòlia, Mx.).

Fruit, pulpy.

Stems, climbing by help of slender and naked-tipped coiling tendrils.

"'The wilde Vine with her branches few \& clusters thinne Adorns our countrey Bowre, a seemly thing I winne."

Gerard's Herball, London, 1597.

"The subtlest, most evanescent of all sweet odors, that of the wild grape-vine!"-Atrantic Monthly, September, 1893 . 
"By the river bank he wandered, Through the Muscoday, the meadow, Saw the grape-vine, the Bemahgut, Trailing o'er the elder-branches, Filling all the air with fragrance."

Longfellow's " Hiawatha."

"Almighty God for the comfort of mankind ordained wine; but decreed, therewith, that it shoulde be moderately taken, for so it is holsom \& comfortable; but when measure is turned into excesse it becometh unwholsome, $\&$ a poison most venemous, relaxing the sinewes, bringing with it the palsie $\&$ falling sicknes : to the aged it bringeth hot fevers, frensie, \& lecherie, consumeth the liver \& other of the inward parts : . . . Finally in a word to conclude: this excessive drinking of wine dishonoreth noblemen, beggereth the poore, \& more have been destroied by surfeiting therewith than with cruell battell."Gerard's Herball.

Tendrils are modified forms of leaf, leaf-stem, flowerstem, branch, or stipule. Meehan comments interestingly on their doings. Until they find a support they are in constant motion. "I have demonstrated," he says, "that this motion, if it remains unsatisfied, is exhausting to the plant. It is a drain on its health and vigor." Darwin says that generally if a tendril fails to catch anything it merely gradually withers, but that in a few species, if it fails, at first it slowly bends downward, then loses its power of clasping, and very soon disarticulates itself and drops off like a leaf in autumn.

Some tendrils appear as though they made deliberate choice. "Knowing that the tendrils avoid the light, I gave them a glass tube blackened within and a well-blackened piece of zinc. They quickly curled about the tube, and bent abruptly around the edge of the zinc; but they 
soon recoiled from these objects with what I can only call disgust, and straightened themselves," They were dissatisfied with the smooth surfaces; when rough ones were substituted they at once seized upon them and held fast.

In animals the will and the nerve-centres are responsible for the action of the muscles. What is responsible in the plant for the action of the tendrils? Why does the tendril reach straight out, seemingly as eager as a finger to reach the needed support? The support is reached. Is the tendril satisfied? No more than is a baby when its fingers touch the rounds of the supporting chair. The chubby fingers close. The muscles of the hand and arm contract and stiffen, and so the child holds and stands where else it would have fallen. Why does the tendril when it feels the support likewise stiffen and cling with all its might?

More! Why does it at the same time throw its entire straight length into a spiral? True in that form it can better withstand a sudden strain - as can the twisted cable that holds a ship to its anchorage,- - but the vine is not supposed to know that. Then why does it act ?

Besides, there is a mechanical difficulty. Take a fine wire. Fasten it firmly at each end. Now try to throw it into a single even spiral. You cannot do it. Neither can a plant do so with its tendrils. But the plant solves the difficulty. It makes a double spiral-i.e., near the middle the direction of the curve is evenly and gracefully reversed, and with no sacrifice whatever of strength or of beauty, Ah, how often the "wise" men have to answer their own or others' persistent "Why?" simply with "I do not know." One can explain in part, but back of it all is something that cannot be explained.

[See further concerning tendrils, under Gourd Family, pp. 80, 81.] 


\section{GUIDE TO SPECIES.}

(a) Bark shreddy, tendrils forked.

(b) A tendril or flower-cluster opposite each leaf on the new wood. (I) Northern Fox-Grape (V. labrúsca, L.)

(b) Tendrils and flower-clusters intermittent (wanting opposite each second or third leaf on the new wood).

(c) Leaves sometimes rusty-downy beneath, especially when young, sometimes with a bluish bloom. Branchlets cylindrical. (2) Summer Grape (V. æstivàlis, Mx.).

(c) Leaves mostly with whitish persistent down. Branchlets angled. West and South. (3) Downy Grape (V. cinèrea, Eng.).

(c) Leaves usually not downy (smooth or short hairy beneath).

(d) Fruit very small (about one quarter inch in diameter), without bloom. Clusters, mostly loose. (4) Frost-Grape (V. cordifolia).

(d) Fruit, one third to five twelf ths inch in diameter, with a thick bloom. Clusters mostly compact. Western New England to Pennsylvania and westward. (5) River-Grape (V. ripària, Mx.).

(d) Fruit, one third to five twelfths inch or more in diameter, shining, without bloom. Clusters mostly loose. West and South. (6) Red Grape (V. palmàta, Vahl.).

(a) Bark not shreddy, tendrils not forked. (7) Southern Fox-Grape (V. rotundifòlia, Mx.).

Fig. 8.-(I) Northern Fox-Grape. V. labrisca, $L$.

Flowers, the pistillate forms in compact clusters. June.

Leaves, variable, from four to six inches wide, very rustywoolly (or sometimes whitish-woolly), when young, and continuing so beneath when grown. Tendrils, once or twice forked; a tendril or flower-cluster opposite each leaf. Bark, loose and in shreds. Young branchlets, woolly. 


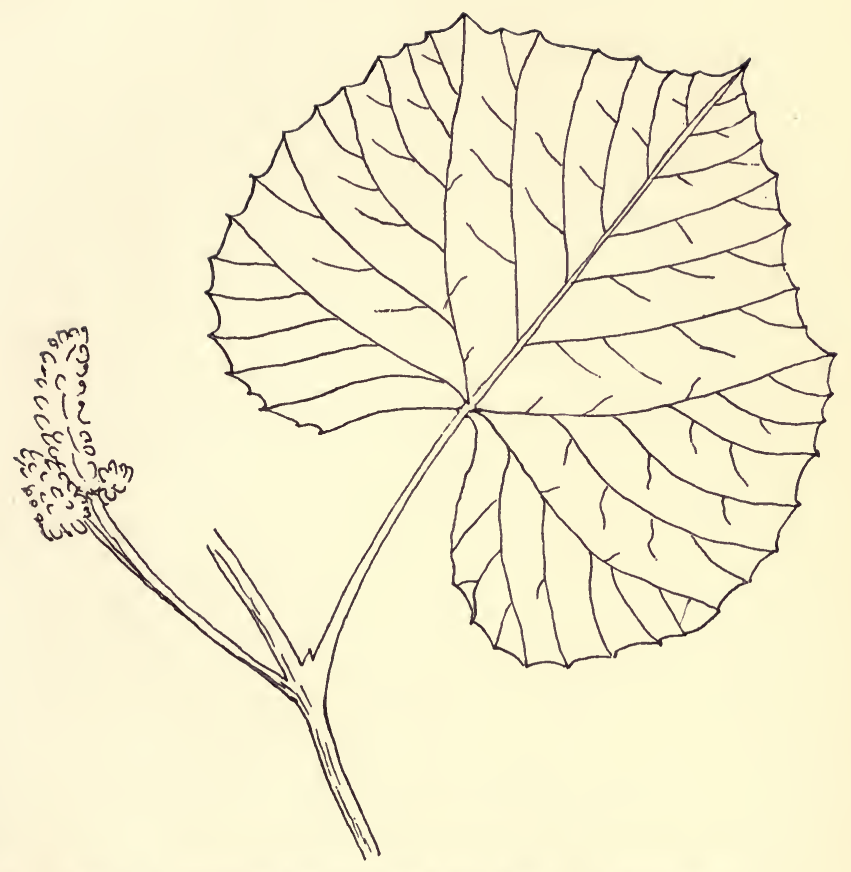

$2 I$

Fig. 8.-Northern Fox-Grape (young leaf). (V. labrúsca, L.) 
Fruit, large (half to three quarters inch in diameter), dark purple or amber color, with a tough pulp, and a pleasant musky ("foxy") flavor and odor. It is the very best for making grape-jellies. Clusters, small to medium. September, October.

Found, in moist groves from New England to South Carolina.

A vine that climbs often over great distances, reaching like cables among the branches of high trees. From this species are derived some twenty cultivated varieties. Of these, four are now widely introduced and of great market value, namely: Isabella, Catawba, Concord, and Diana. With these might perhaps be included a fifth, the Hartford Prolific. The first two, it is claimed, originated in North Carolina. The counter-claim that the Isabella is an imported grape is disproved by the fact that it sometimes reverts completely to the Fox-Grape-in leaf and fruit. Also seedlings from it are sometimes fruitless, as happens with other American species, but apparently never with European species. Dr. Laspeyre, of North Carolina, appears to have been its first cultivator, about 1805 ; for in 1810 he was selling it in the Wilmington markets. The name, Isabella, was given in compliment to Mrs. Isabella Gibbs, who is said to have taken a cutting from it to Brooklyn. (See Dr. Curtis's State Report on North Carolina Woods and Timbers.)

The Catawba seems to have originated in Buncombe County, N. C., near the French Broad River.

Fig. 9.-(2) Summer Grape. V. estivalis, $M x$.

Flowers, the pistillate forms in long, loose clusters. June. Leaves, very variable, four to seven inches in width, toothed, and usually more or less three- to five-lobed, 


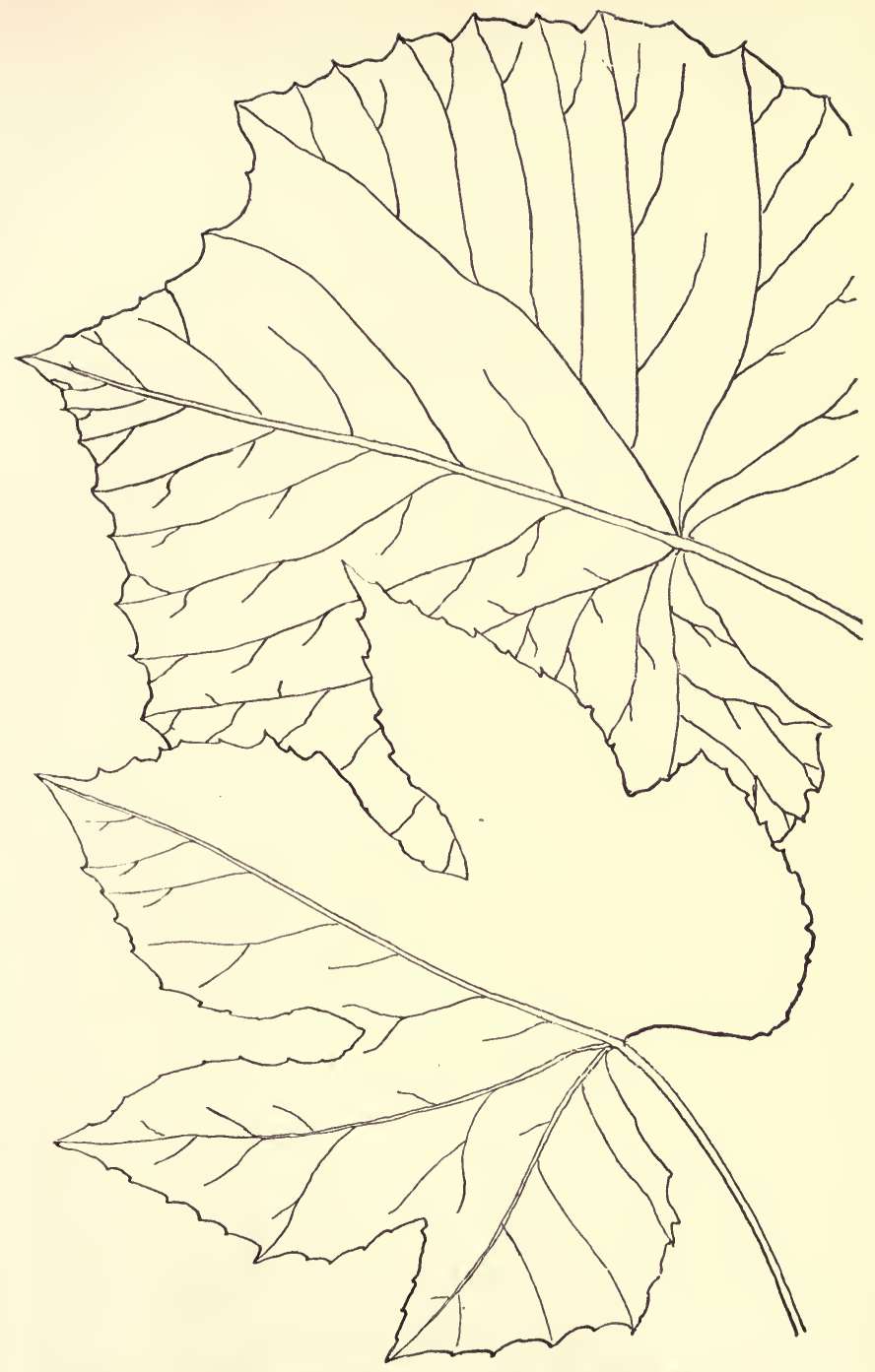

Fig. 9.-Summer Grape. (V. æstivàlis, Mx.) 
sometimes rather thin, and with a bluish bloom or pubescence, sometimes thicker and rusty-downy beneath. Tendrils, forked. Tendrils and flower-clusters, intermittent (wanting opposite each second or third leaf). Branchlets, cylindrical.

Bark, loose and shreddy.

Fruit, small (about half an inch in diameter), dark blue or black with a bloom, well-flavored, in compact bunches six to twelve inches in length. September.

Found, in rich woods and thickets, common and widely distributed North and South.

Vines with slender, high-climbing stems. From V. æstivàlis, $\mathrm{Mx}$., at least twelve cultivated varieties are derived.

This species is sometimes divided into two- $\mathrm{V}$. bicolor, Le Conte, for forms found mostly in the North, and V. æstivàlis, Mx., for the Southern forms.

Resembling Fig. 8.-(3) Downy Grape. V. cinèrea, Eng.

Leaves, entire or slightly three-lobed, greyish-downy, the down persistent beneath. Leaf-stems, very long. Tendrils, forked. Tendrils and flower-clusters, intermittent (wanting opposite each second or third leaf). Branchlets, angular, densely downy or woolly.

Bark, loose and shreddy.

Fruit, small, black, without bloom, in large, compound, and long-stemmed clusters.

Found, from Central Illinois to Kansas and Texas. 


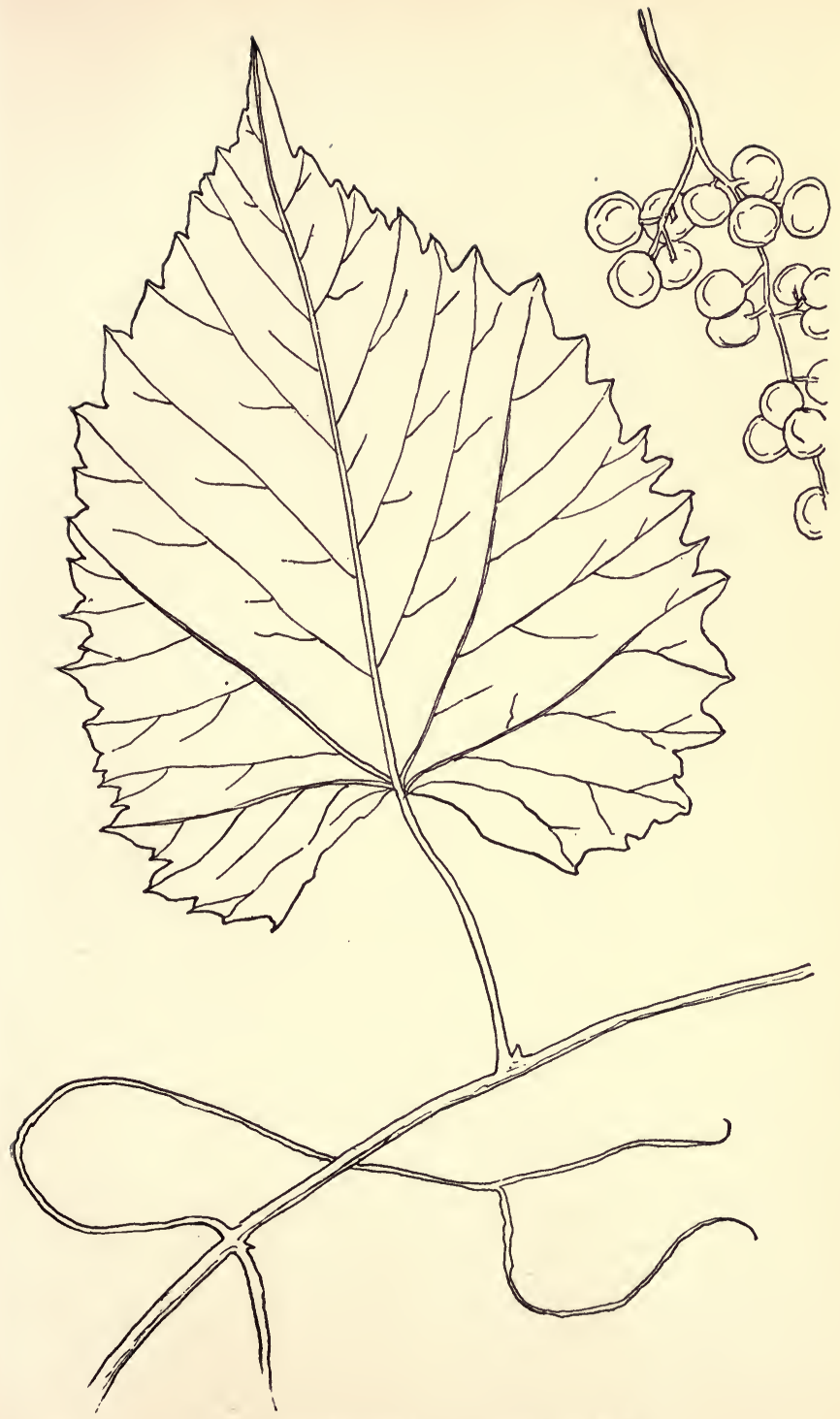

Fig. ro.-Frost-Grape. (V. cordifolia, Mx.) 
Fig. Io.-(4) Frost-Grape. Winter-Grape. Chicken-Grape. 'Possum-Grape. $V$. cordifolia, $M x$.

Flowers, in loose, many-blossomed clusters. May and June.

Leaves, three to five inches wide, coarsely and sharply toothed, and sometimes slightly three-lobed; smooth and shining above, usually short-hairy on the ribs beneath and on the leaf-stem; green on both sides. Apex, pointed. Base, heart-shaped, usually deeply so. Stipules, small and soon falling. Tendrils and flower-clusters, intermittent (lacking opposite each second or third leaf).

Bark, loose and shreddy.

Fruit, about one quarter inch in diameter, black, shining, without bloom ; very acid until made pleasant-flavored by sharp frosts. Seeds, one or two rather large. (lusters, loose, seldom compound. November.

Found, in thickets and along streams from New England westward and southward.

A vine climbing to the height of ten to twenty feest.

Fig. II.-(5) River-Grape. V. vulpina, L. V. riparia, $M x$.

This species differs from the preceding (Frost-Grape) chiefly in the following items :

Flowers, in smaller and more compact clusters.

Leaves, more shining, and more deeply and more frequently three-lobed. Stipules, larger and more persistent. 


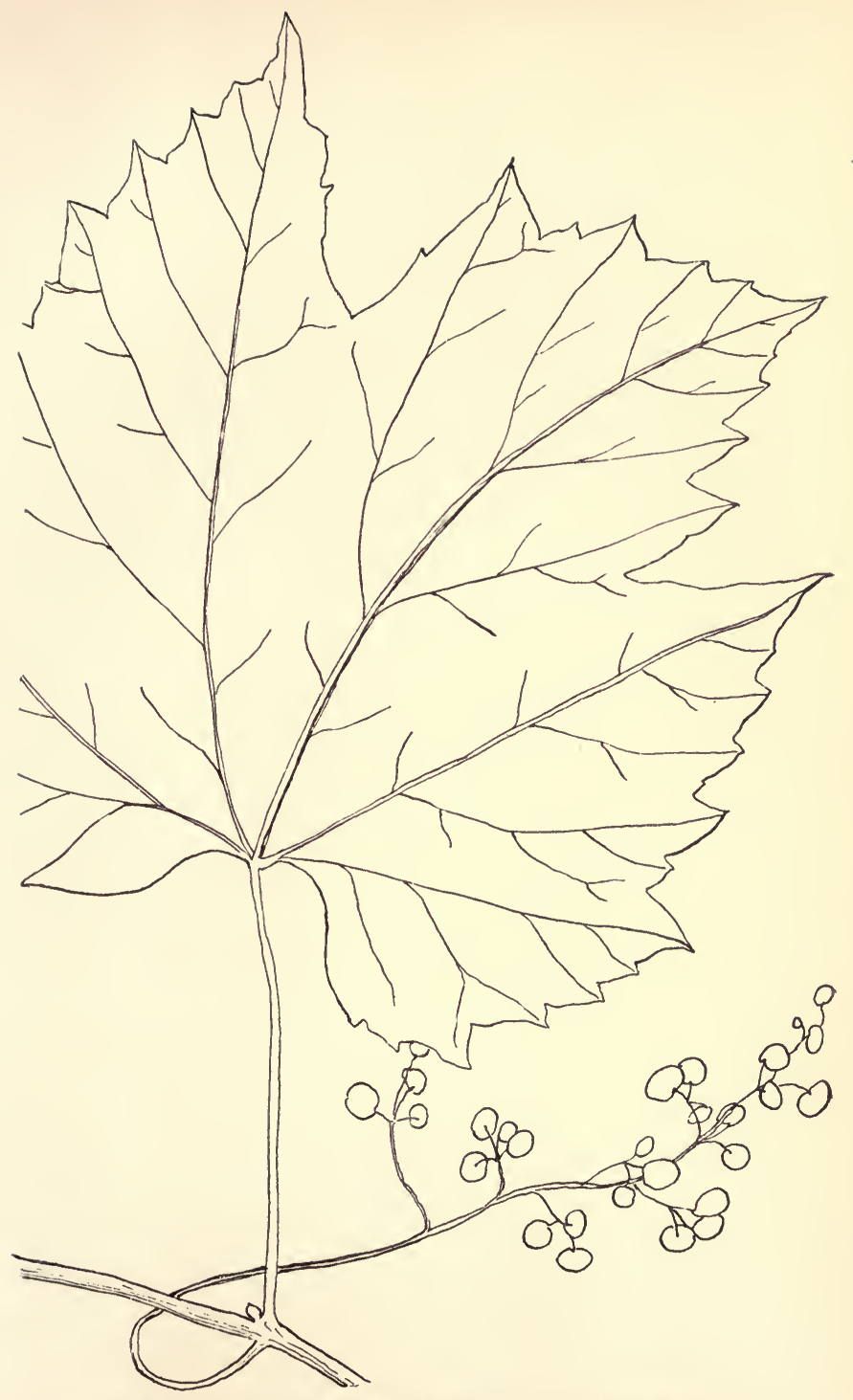

27 Fig. Ir.-River-Grape, with young fruit. (V. vulpina, L.) 
Fruit, one third to five twelfths inch in diameter, with a thick bloom; ripening early. Seeds, very small. Clusters, small, generally compact.

Found, from Western New England to Pennsylvania and westward.

Fig. 12.-(6) Red Grape. V. palmàta, Vahl. V. rubra, $M x$.

Flowers, in large, loose clusters.

Leaves, smoothish, three to five inches in diameter, lobed, the lobes mostly long-pointed. Tendrils, forked. Tendrils and flower-clusters, intermittent (lacking opposite each second or third leaf).

Bark, loose and shreddy.

Fruit, one third to five twelfths or more inches in diameter, black when ripe, shining, without bloom, ripening late. Seeds, rounded, very large. Clusters, loose, seldom compound.

Found, from Illinois to Missouri and southward.

Fig. 13.-(7) Southern Fox-Grape. Muscadine. Bullace. $V$. rotundifolia $M x$.

Flowers, in small clusters with crowded blossoms. May.

Leaves, two to three inches across, rounded (or rarely slightly three-lobed or angled), edge very coarsely toothed with broad somewhat blunt teeth; smooth and shining on both sides (or rarely slightly downy). Base, heart-shaped. Tendrils, not forked. Tendrils and blossoms, intermittent. 


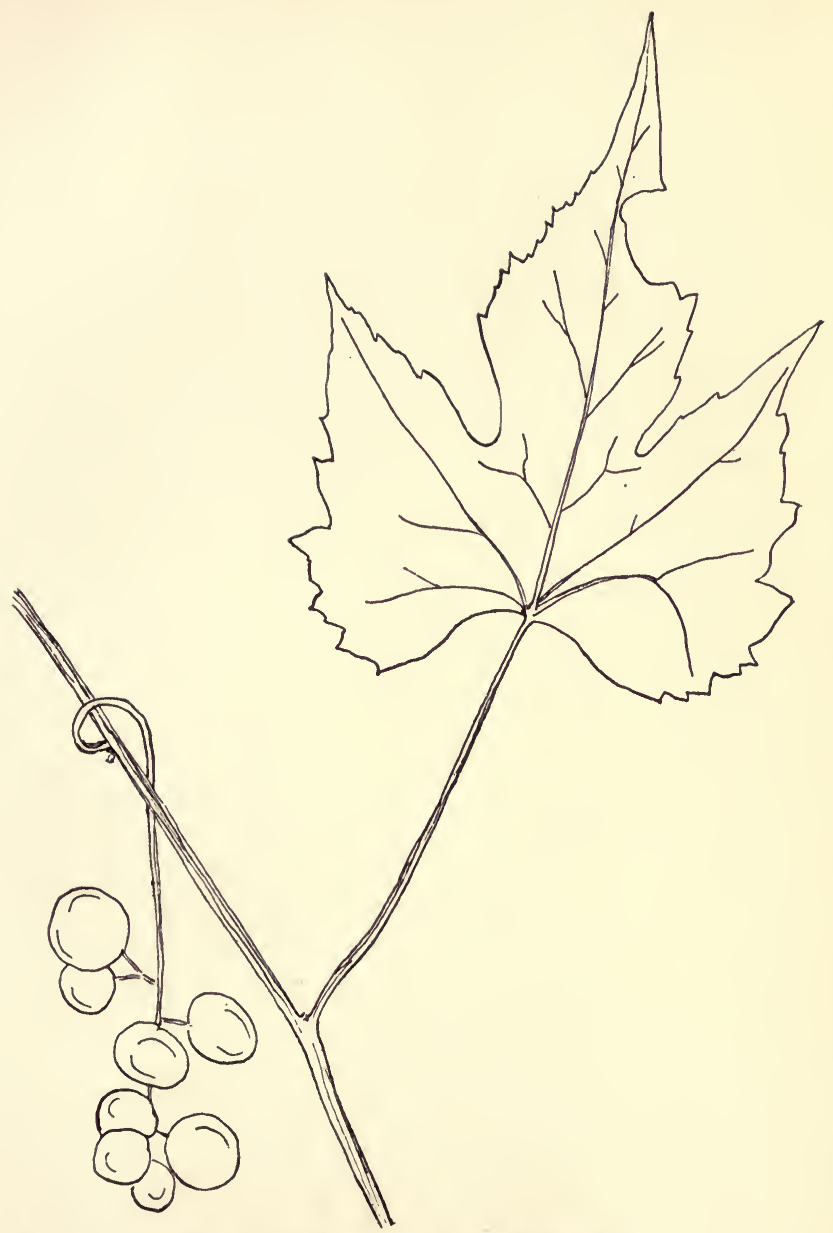

29

Fig. 12.-Red Grape. (V. palmàta, Vahl.) 
Bark, pale and smooth, not shredded. Pith, continuous through the joints.

Branchlets, with minute dots.

Fruit, large (half to three quarters inch in diameter), purplish, without bloom, very tough-skinned, with pleasant musky flavor; few in a bunch; ripening late. Seeds, with wrinkles across both sides.

Found, often in cultivation, and native just south of our limits, from Maryland to Kentucky and Kansas, and southward.

The cultivated Scuppernong common in Southern gardens is derived from this species.

\section{(2) Genus Ampelópsis, Mx.}

From two Greek words meaning " vine" and " appearance."

Fig. I4.-Virginia-Creeper. American Ivy. Woodbine. $A$. quinquefolia, $M x$.

Flowers, small, greenish, in clusters. Petals, five, concave, spreading, thick. Calyx, slightly five-toothed. Seedcase, two-celled, each cell with two young seeds. Style, very short. July.

Leaves, alternate, compound. Leaflets, three to seven (usually five), long and pointed, radiating from a centre; edges coarsely sharp-toothed above the middle, entire toward the base; smooth, brilliantly colored in the fall. Tendrils, swelling at the tips into suckerlike disks by means of which the plant clings firmly to walls and trees in its extensive climbing. 


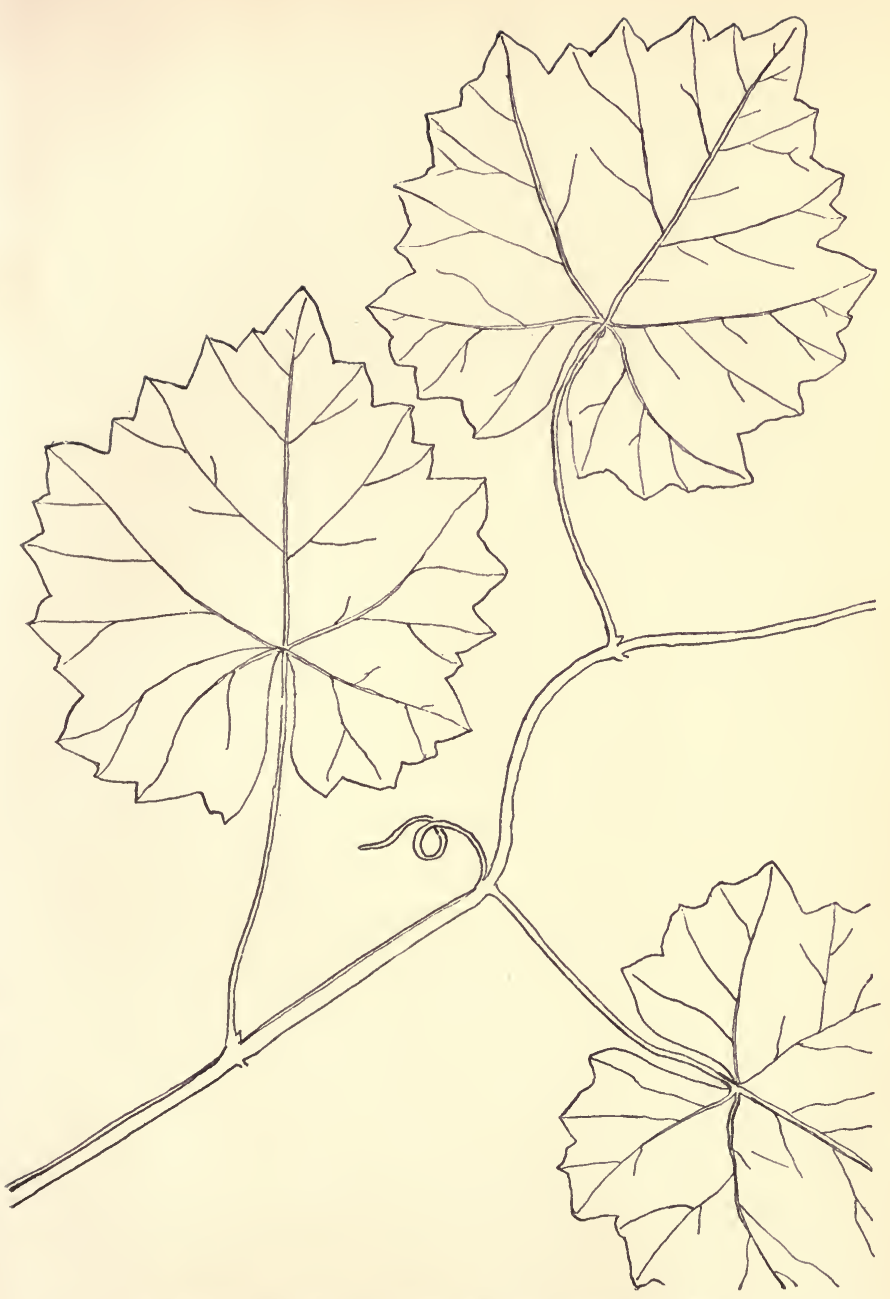

31 Fig. 13.-Southern Fox-Grape. (V. rotundifòlia, Mx.) 
Fruit, about the size of peas, dark blue, in loose clusters; two-celled, each cell with one or two ripened seeds. October.

Found, wild in low, rich ground, from Florida northward and westward, and everywhere in cultivation.

A vigorous woody climber, covering trees and walls of ten to the distance of fifty feet; very useful in cultivation for screens and trellises; and very ornamental, especially in the autumn with its brilliant crimson and scarlet and purple foilage.

For some reason, perhaps because of its climbing habit and its inappropriate popular name of American-Ivy, the Virginia-Creeper is often feared as something poisonous. It climbs a tree trunk somewhat as does the Poison Ivy (Rhus rádicans, L.), but it is easily distinguishable and is entirely harmless. One should remember that the VirginiaCreeper has five finger-like leaflets that are suggestive of the fact that one's own five fingers can safely handle it; while the Poison-Ivy has but three.

"In the course of about two days after a tendril [of woodbine] has arranged its branches so as to press on any surface, the curved tips swell, become bright red, and form on the under sides the well known little disks or cushions with which they adhere firmly. . . Since they adhere to smooth surfaces, . . . this alone renders it probable that some cement is secreted, . . . the quantity however must be small. . . . It must not be supposed that the attachment is effected exclusively by the cement, for the cellular outgrowth completely envelops every minute and irregular projection and insinuates itself into every crevice."-DARWIN. 


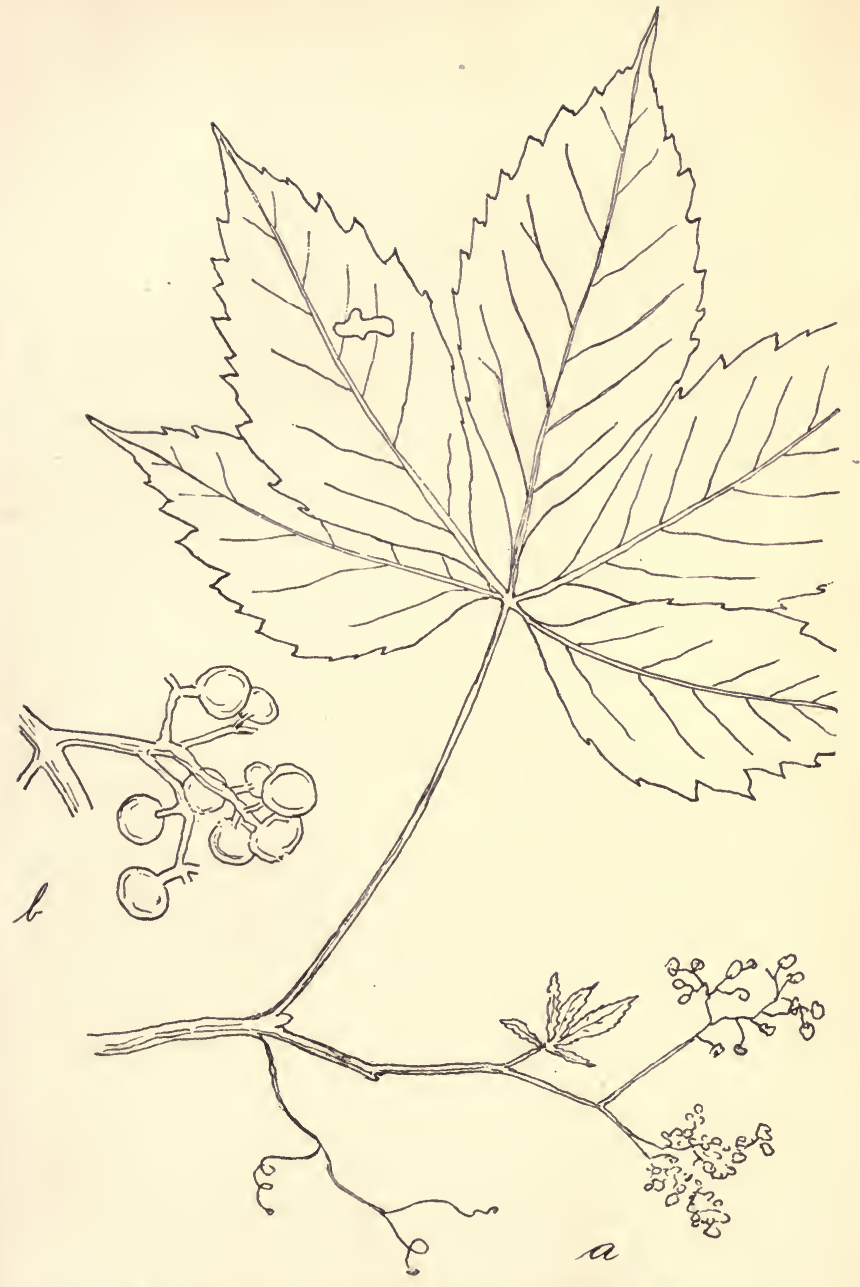

Fig. 14.-Virginia-Creeper. (A. quinquefòlia, Mx.)

$a$. Young leaf and flower-buds, $b$. Fruit. 
No. 6.-Family ANACARDIÀCEÆ. (Sumach Fam.)

Genus Rhus.

Possibly from a word meaning "red."

Fig. 15.-Poison-Ivy. Poison-Oak. R. rádicans, L. R. Toxicodéndron, $L$.

Flowers, small, greenish, in loose clusters from the axils of the leaves; the staminate and pistillate forms on different plants. Petals, five, not united. Sepals, five. Stamens, five, alternate with the petals. Styles, three. Seed-case, free, one-celled, with one seed.

Leaves, compound, alternate. Leaflets, three; edges, entire or variously sharp-notched ; mostly pointed, and somewhat downy beneath.

Fruit, small, rounded, pale brown or whitish, smooth, not splitting when ripe, one-seeded. Stone, ridged or lined. September. An almost dry drupe.

Found, from Canada to Georgia, climbing often in great profusion over walls and fences and up the trunks of trees, taking also at times the shrub form.

A woody plant which takes all positions; sometimes it is erect (one to three feet high); often it is prostrate and trailing; oftenest, perhaps, it is climbing.

In its climbing form it covers the posts of fences, the trunks and branches of trees, stone walls-clinging tenaciously wherever it goes by multitudes of thread-like rootlets, and sometimes reaching a distance of forty or even fifty feet, with a stem from two to five or six inches in diameter. At times it so closely covers its growing support as to smother it. 


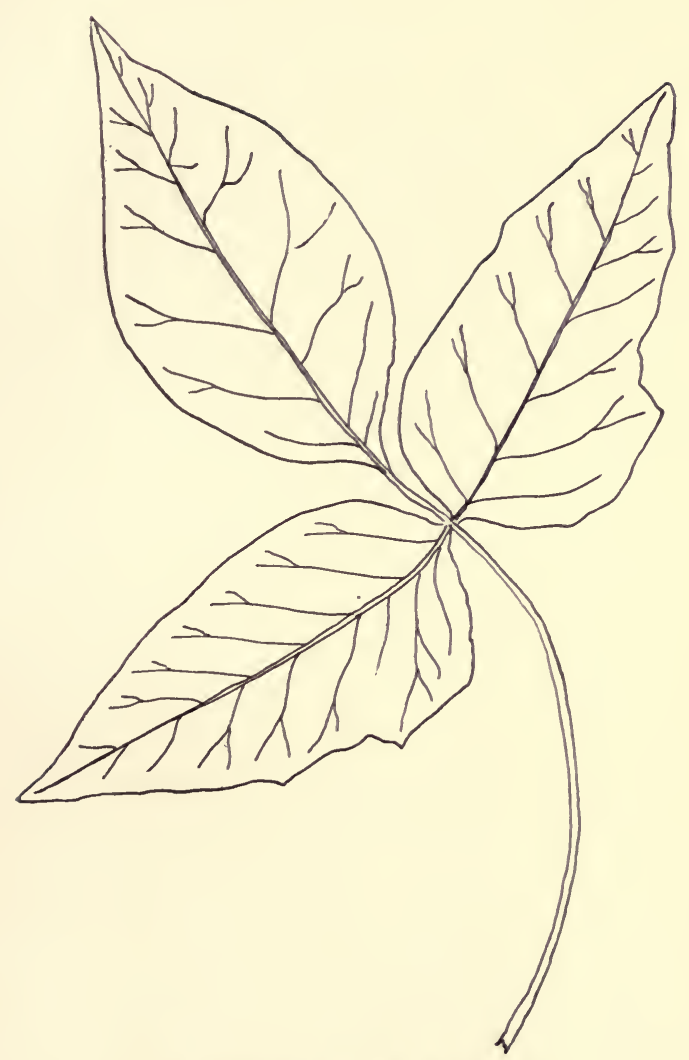

35 Fig. 15.-Poison-Ivy. (R. rádicans, L.) 
The plant is violently poisonous to the touch, causing in most persons a painful eruption : some are poisoned by it without touching it, probably by means of the drifting pollen of its flowers. A recommended application is sugar of lead applied, after the use of saline cathartics, or a thick paste of bi-carbonate of soda rubbed into the skin as soon as the eruption appears. It is also claimed that relief and, if used promptly, frequent cure follow the use of apis mellifica or of belladonna, taken in homœopathic doses. There are wellnigh as many recommended antidotes as there are for the bites of rattlesnakes; and what will help in some cases will not in others.

\section{No. 7.—Family LEGUMINÒSÆ. (Pulse Fam.)}

Flowers, irregular (papilionaceous, i.e., butterfly-like). Petals, five, distinct (excepting the two that unite to form the keel) ; the upper one, called the "standard" or "banner," larger than the others and enclosing them in the bud, and when fully blossomed usually turned backward or widely spreading; the two side ones, called "wings" slanting, and lapping the lower ones ; the two lower ones, forming the "keel" usually more or less united by their front edges, and enclosing the stamens and the style. Calyx, of five more or less united sepals. Stamens, ten, either all or, much oftener, all but one united toward the base. Style, simple. Seed-case, free, one-celled; or (in Genus I, Desmòdium) with cross divisions forming a two- to several-celled and jointed pod, each joint with one seed.

Leaves, compound, alternate, edge of leaflets entire. Stipules, present. Leaf-stems, swollen at the base.

Fruit, a legume, i.e., a one-celled and two-valved pod, like a pea-pod; or in Genus I (Desmòdium) a 
loment, i. e., a jointed pod with one or more cross divisions, and one seed in each joint.

Herbaceous vines, one species (the Butterfly-Pea, Clitòria Mariàna) woody at base.

\section{GUIDE TO GENERA.}

(a) Leaflets, three. Tendrils, none. Pod, either jointed, with one seed for each joint, or one-celled and oneseeded.

(b) Pod, jointed, with one seed to each joint. (I) Desmòdium (Bush-Trefoil).

(b) Pod, one-celled and one-seeded. (2) Lespedèza (Bush-Clover).

(a) Leaflets, three. Tendrils, none. Pod, neither jointed nor one-seeded, excepting sometimes in the lower and usually underground pods of the Hog-Peanut (No. 8).

(b) Standard (the large upper petal), curved back, and spreading. Seeds, four to ten, oblong with squared ends, kidney-shape, or four-sided. (3) Phasèolus (Kidney-Bean).

(b) Standard, erect. Vine smooth, ascending. (4) Clitòria (Butterfly-Pea).

(b) Standard, erect. Vine hairy, ascending. (5) Amphicarpæa (Hog-Peanut).

(b) Standard, bending somewhat inward. Vine smooth or minutely downy, prostrate. (6) Galáctia (MilkPea).

(a) Leaflets, five or seven. Tendrils, none. (7) Ápios (Ground-Nut).

(a) Leaflets, an even number. Tendrils or bristles, present at the ends of the leaves.

(b) Leaflets, eight to twenty-four. Style, thread-like, bearded by a tuft or ring of hairs at the apex, especially on the outside (toward the keel). Vícia (Vetches).

(b) Leaflets, six to twelve. Style, flattened and bearded down the inner side (toward the free stamen. (9) Láthyrus (Vetchlings). 
(i) Genus Desmòdium, Desv. Meibòmia (L.), Kuntz.

Fig. 16.-Smooth Bush-Trefoil. D. humifùsum, Beck.

This species closely resembles the next (D. rotundifolium), excepting that it is nearly smooth throughout, with leaves that are oval to egg-shape, and with smaller and narrow and less persistent stipules and stipels. It is found in dry, sandy soil in Maine, and from Pennsylvania to Maryland. It sometimes reaches a length of eight feet.

Fig. 17.-Bush-Trefoil. Tick-Trefoil. D. rotundifolium, D. C.

Flowers, in clusters, axillary or terminal, of few blossoms, purple; standard, reverse egg-shape ; wings, attached to the keel by a slight band. Calyx, five-cleft, more or less two-lipped, with its lobes longer than the tube. Stamens, in two sets (nine united toward the base, and one distinct). August.

Leaves, compound, alternate. Leaflets, three, rounded, hairy on both sides, one to two inches across, with stems and stipels; edges entire. Stipules, conspicuous, persistent, egg-shape, pointed. Leaf-stem, hairy.

Pod, flattened, two- to six-jointed, deeply lobed on the edges, somewhat as in Fig. I6, on a short stalk, very adhesive with its covering of small hooked hairs. Seeds, one in each joint. A loment.

Found, in dry open woods from Florida to New England and westward.

A prostrate vine, herbaceous, hairy, two to four feet long. 


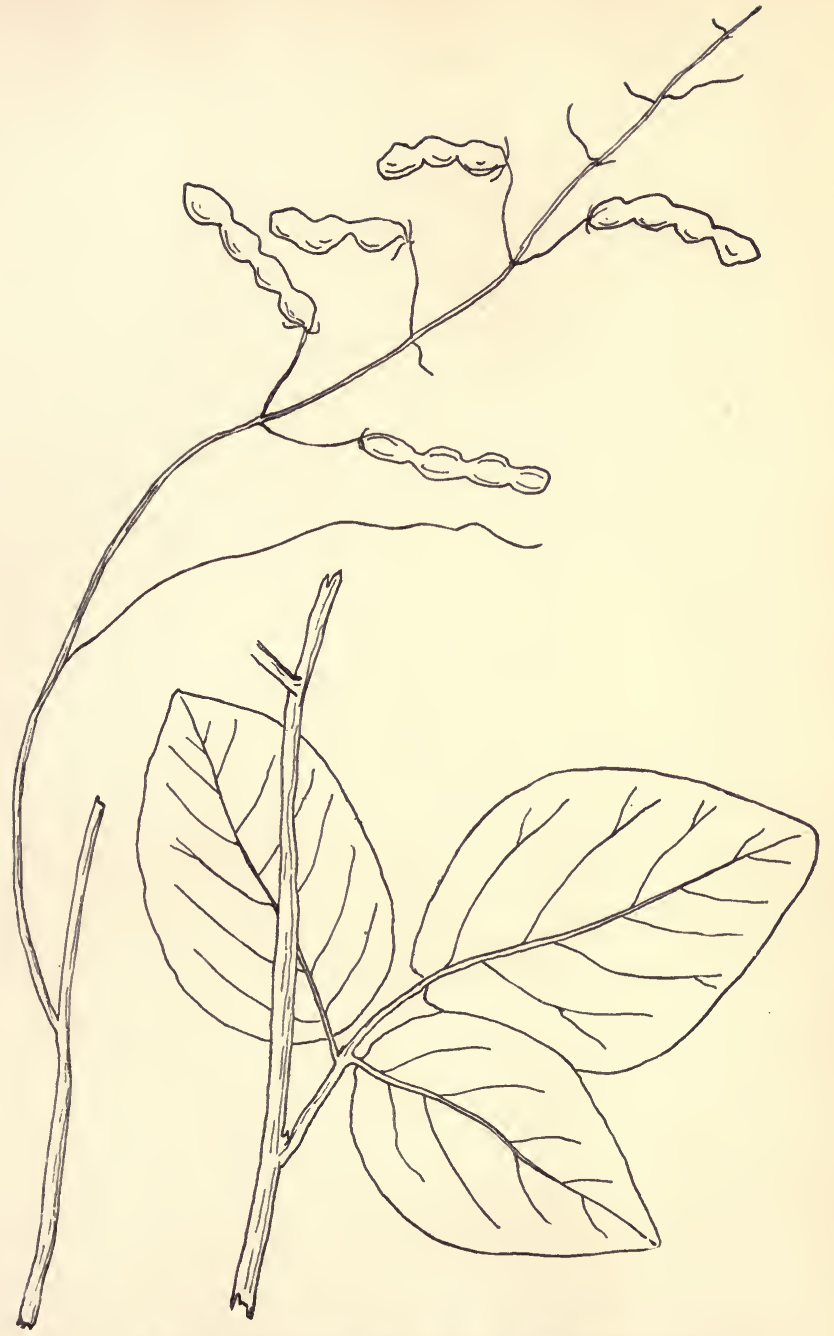

39 Fig. 16.-Smooth Bush-Trefoil. (D. humifusum, Beck.) 


\section{(2) Genus Lespedìza, Mx.}

From the name of a Spanish governor of Florida.

Fig. 18.-Bush-Clover. L. procimbens, Mx. L. rèpens (L.), Bart.

Flowers, in few-blossomed axillary clusters, of two sorts, the larger with stamens and pistils but seldom bearing seed; the smaller with seed-bearing pistils, and oftenest without petals. Corolla, violet-purple, longer than the calyx; the keel as long as the wings. Caly'x, five-cleft, with slender, nearly equal lobes, and with two small bracts beneath. Stamens, in two sets (nine united at base, and one distinct). Cluster-stems, two to five inches long, very slender. August, September.

Leaves, compound, alternate. Leaflets, three, one quarter to three quarters inch long, oval to reverse eggshape, on very short stems, without stipels, smooth above.

Pod, rounded, small, flat, one-celled, one-seeded. A legume.

Found, common in dry sandy. soil in Canada and the United States.

A slender trailing vine, herbaceous, slightly downy or hairy, one to two feet long.
(3) Genus Phask̇olus, Tourn.
(Kidney-Bean.)

Flowers, in axillary clusters. Keel, enclosing the stamens and style, and either twisted into a spiral or strongly incurved. Calyx, five-toothed with the two upper teeth more or less united. Stamens, in two sets (nine united toward the base, and one distinct). 

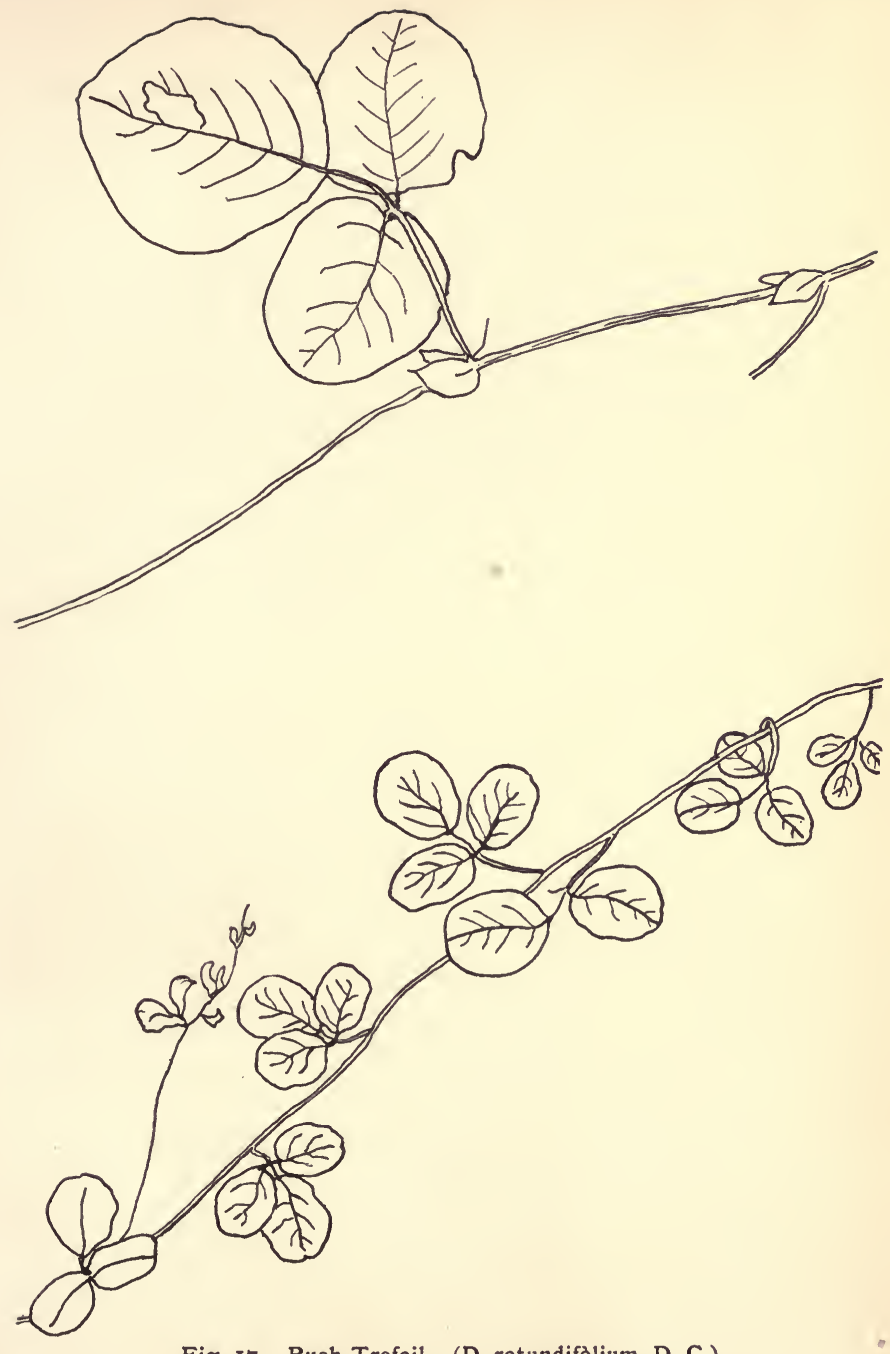

Fig. I7.-Bush-Trefoil. (D. rotundifolium, D. C.)

4I Fig. 18.-Bush-Clover. (L. procúmbens, Mx.) 
Leaves, compound, alternate. Leaflets, three with stipels.

Pod, four- to ten-seeded. Seeds, oblong with squared ends, kidney-shape, or four-sided.

Herbaceous vines. The Lima Bean, and other favorite climbing beans of the garden belong with this genus.

Fig. I9.-Kidney-Bean. Wild-Bean. P. polystáchyus (L.), B.S. P. P. perennis, Walt.

Flowers, scattered in loose axillary clusters that are twice as long as the leaf-stems or more. Corolla, purple or violet, small. Keel and the included style and stamens, twisted. Style, bearded along the upper side. July and August.

Leaflets, three, one and a half to three and a half inches long, rounded egg-shape, the terminal one often somewhat heart-shape. Apex, short-pointed.

Pod, about two inches in length, strongly curved, drooping, tipped with the base of the style. Seeds, four to five, flattened, dark purple, kidney-shape. A legume.

Found, in dry ground from Canada to Florida and westward. Common.

A twining, herbaceous vine, slender, somewhat downy; from a perennial root. Stem, four to seven feet long. 


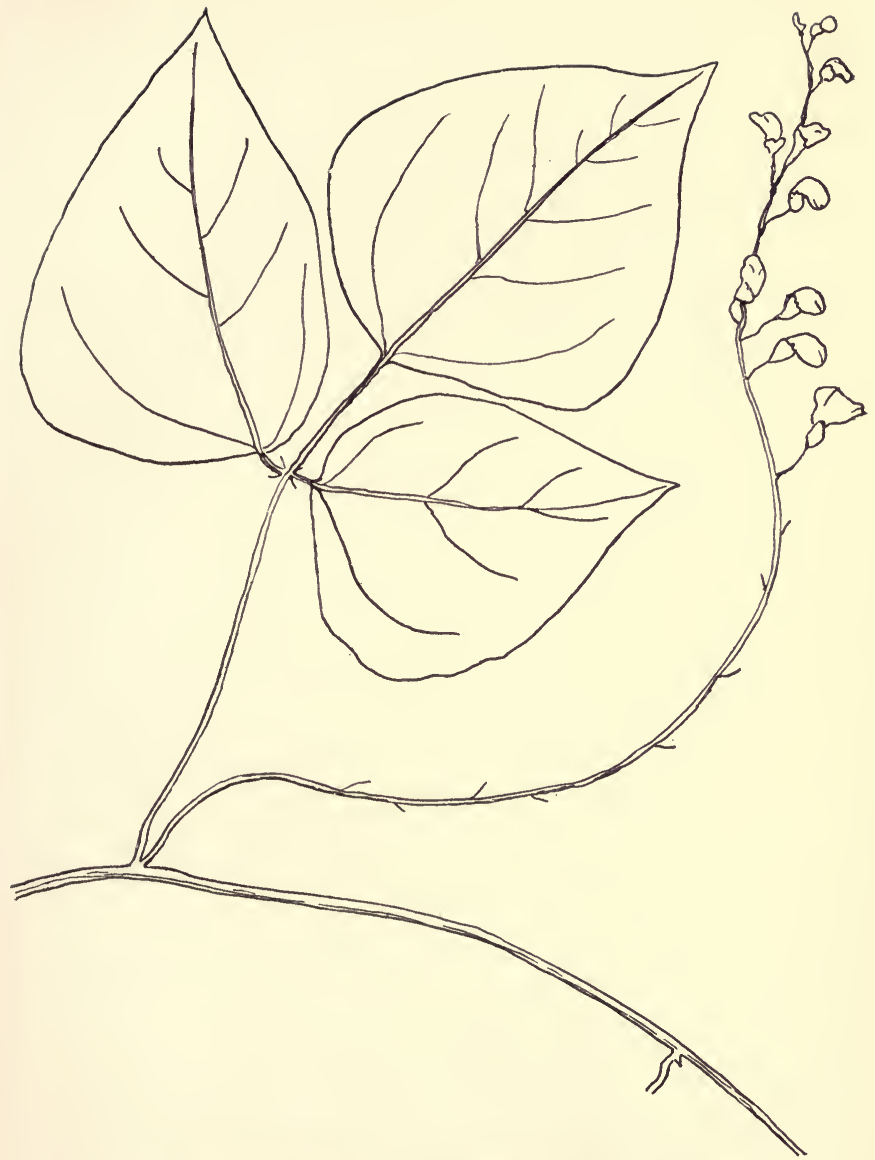

43 Fig. 19.-Kidney-Bean. P. polystáchyus (L.), B. S. P. 
Fig. 20.-Various-Leaved Kidney-Bean. P. helvolus, L. P. diversifolius. P. Strophostijles anguldsa, Ell.

Flowers, stemless, in clusters of four to seven blossoms at the ends of the cluster-stems. Cluster-stems, four to eight inches long. Corolla, greenish-white and purple, the standard large and rounded. Calyx, with two bracts beneath. August, September.

Leaflets, three, one half to one and two thirds inches long (oftenest about one inch), from egg-shape to narrow oblong ; commonly more or less three-lobed.

Pod, straight, or nearly so, and nearly cylindrical, two to three inches long, one quarter inch wide, nearly smooth. Seeds, four to eight, one quarter inch long, oblong, usually very downy. A legume.

Found, on and near sandy shores and river banks, along the coast from Massachusetts southward, and from the Great Lakes to Kansas and Texas.

A branching, herbaceous vine, twining or prostrate (usually spreading on the ground), one to six feet long.

Fig. 21.-Umbelled Kidney-Bean. P. umbellàtus (Muhl.), Britton. S. pedunculàris, Ell.

Flowers, stemless, in few-blossomed clusters.

Leaflets, three, usually about one inch in length, egg-shape to narrow-oblong, seldom lobed.

Pod, one and a half to two inches long, scarcely one sixth inch wide, straight or nearly so. Seeds, one sixth inch long or less. A legume. 


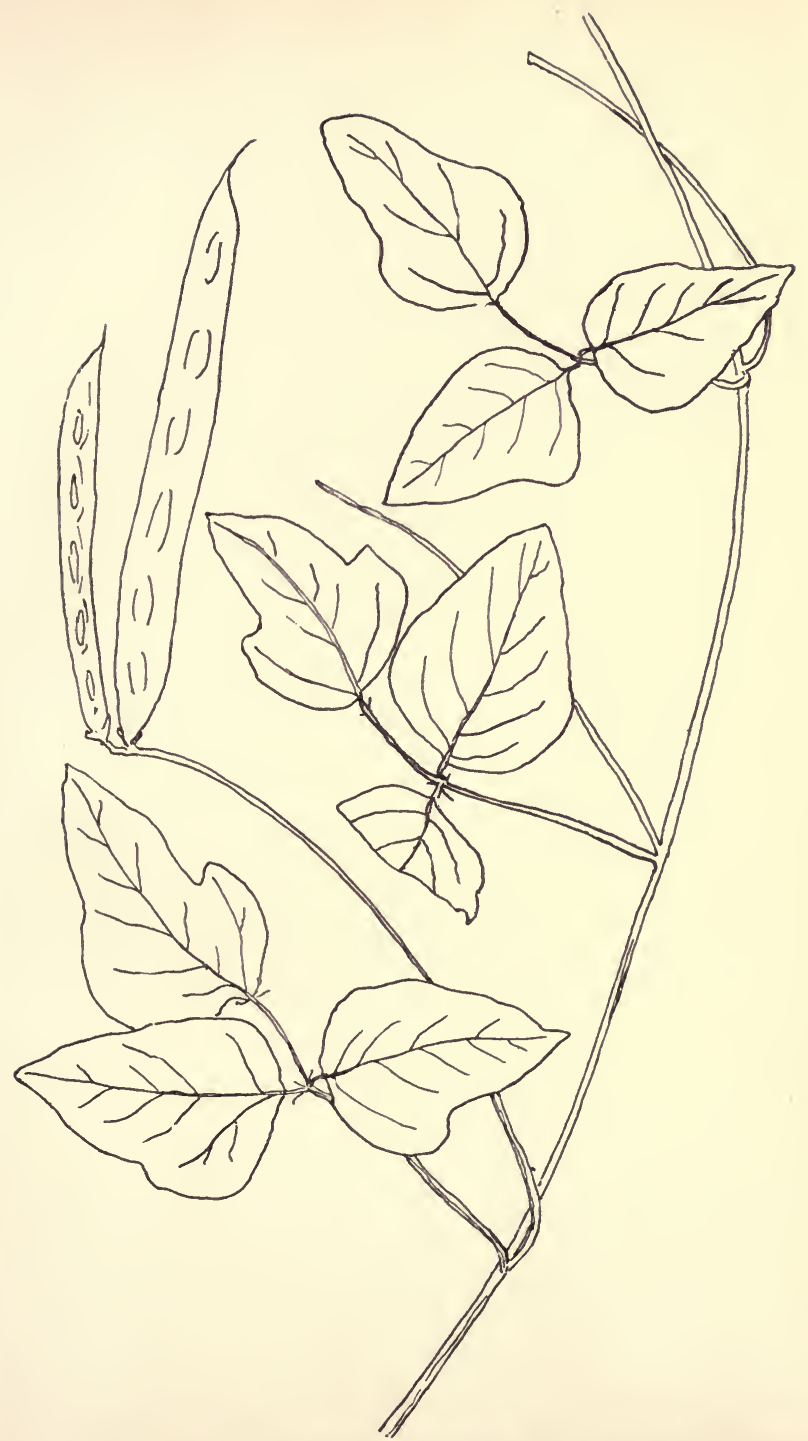

45 Fig. 20.-Various-Leaved Kidney-Bean. (Phasèolus hélvolus, L.) 
Found, in sandy ground from Long Island and New Jersey to Florida, and westward to Southern Indiana and Texas.

A vine two to four feet long, from a perennial rootstock.

Fig. 22.-Few-Flowered Kidney-Bean. P.pauciforus, Benth.

Flowers, in few-blossomed clusters. Cluster-stems, much longer than the leaf-stems.

Leaflets, three, one to two inches long, slightly hairy, long egg-shape to very narrow, not lobed. July, August.

Pod, one to one and a half inches in length, straight, slender, flattened, downy or hairy. Seeds, five to eight. A legume.

Found, from Indiana to Minnesota and southward to Missouri and Texas.

A slender prostrate vine, downy or hairy, two to four feet in length.

\section{(4) Genus Clitòria, L.}

Fig. 23.-Butterfly-Pea. C. Mariàna, L.

Flowers, nearly two inches in length (standard pale purple or blue, the rest whitish or blue and white), in oneto three-blossomed axillary clusters. Standard, erect, rounded to reverse egg-shape, usually notched above, not spurred, much larger than the other petals. Keel, shorter than the wings, pointed and incurved 


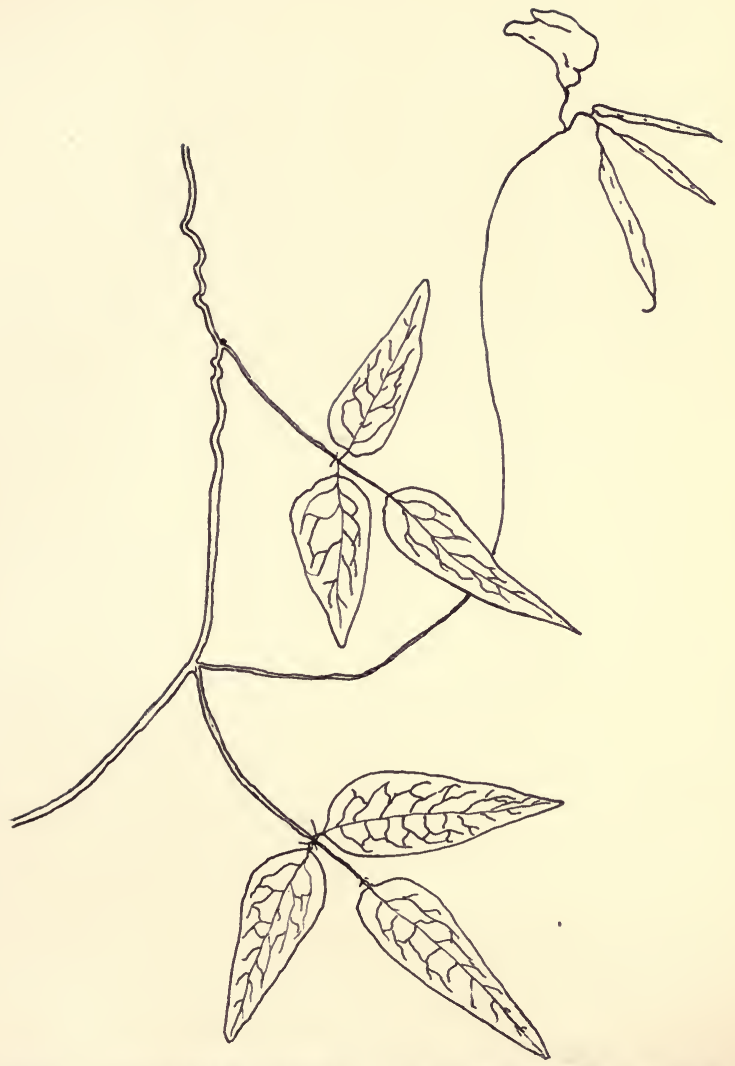

Fig. 21.-Umbelled Kidney-Bean. P. umbellàtus (Muhl.), Britton. 47 
on long claws. Calyx, tubular, five-toothed, threequarters inch long, with small bracts beneath. Stamens, united toward the base. Stole, curved and bearded down the innẹr side. Cluster-stems, shorter than the leaves. July, August.

Leafets, three, usually about one inch long and half an inch wide though often larger, mostly long eggshape. Apex, blunt or slightly pointed. Base, usually rounded or slightly heart-shaped. Stipules and bracts, awl-shape.

Pods, one and a half to two inches long, very narrow, flattened, knotty, pointed with the remains of the style. Seeds, three or four.

Found, in dry ground from New Jersey to Florida, and westward to Missouri and Texas.

A smooth perennial vine, ascending and twining, woody only at the base. Stem one to three feet in length, slender and branching.

\section{(5) Genus Amphicarpéa, Ell.}

From two Greek words meaning " both" and "fruit," with reference to the different forms of the pods.

Fig. 24.-Hog-Peanut. A. commòsa (L.), Riddell. A. monòica, Nutt.

Flowers, purplish, two sorts, in axillary, usually few-blossomed, drooping clusters, those on the upper branches complete, but seldom fruiting; those on the lower creeping branches bearing fruit, but with few stamens, if any, and with the corolla lacking or merely rudimentary. Keel and wings, nearly straight and 


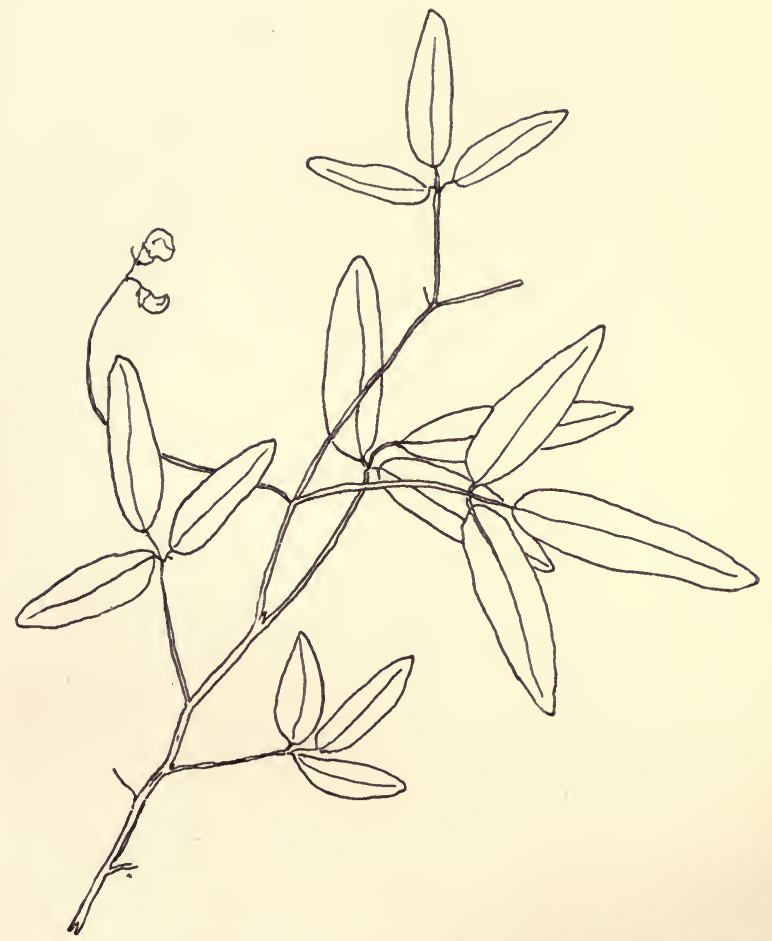

Fig. 22.-Few-Flowered Kidney-Bean. (P. pauciflòrus, Benth.) 
similar, and partly enfolded by the reverse egg-shaped standard. Calyx, tubular, or bell-shape, with four (sometimes five) short and nearly equal teeth-that of the upper flowers about one sixth of an inch in length. Bractlets, minute, or lacking. Stamens, in two sets, in the upper unfruitful flowers ; in the lower ones, wanting, or, if present, not in sets. Style, not bearded. Seed-cases, of the upper flowers, smooth with hairy margins; of the lower ones, hairy. August, September.

Leaflets, three, very thin, one half inch to three inches in length, three quarters as wide, somewhat egg-shape, those at the sides with the base oblique. Stipels present.

Pods, of the upper flowers, if present, somewhat curved, with a short stalk, and with three or four dark seeds; those of the lower flowers, one inch in length, hairy, usually beneath the ground, reverse egg-shape or pear.shape, with one large flattened brown seed. A legume.

Found, common, in rich, damp soil, from Canada to Mississippi and Florida.

An ill-named vine, slender, twining, hairy, perennial, herbaceous; the stem much branched, rough in one direction, four to eight feet long.

Resembling Fig. 24.-Pitchers' Hog-Peanut. A. Pitcheri, T. and $G$.

This species differs from the preceding (A. commòsa) chiefly in the following items : 


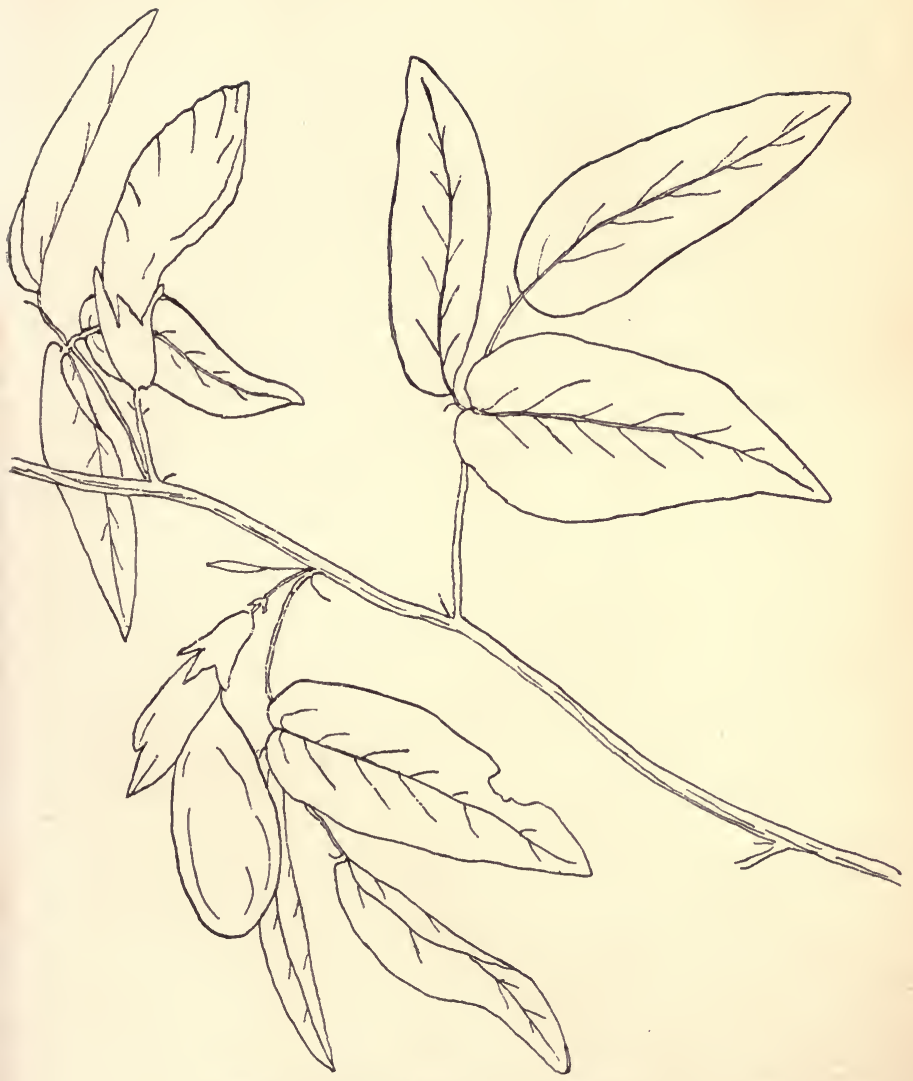

5 I

Fig. 23.-Butterfly-Pea. (C. Mariàna, L.) 
Flowers, The upper ones more frequently producing fruit, the lower ones less frequently. Clusters, erect. Calyx, one quarter inch long. Seed-case, hairy.

Leaflets, usually two to four inches in length.

Pod, one and one third to one and one half inches in length.

Found, from Western New York to Illinois and southward to Louisiana and Texas.

(6) Genus Galáctia, P. Browne.

From a Greek word meaning "milk," because some species were supposed to have a milky juice.

Fig. 25.-Milk-Pea. G. regulàris (L.), B. S. P. G. glabélla, $M x$.

Flowers, from seven twelfths to two thirds of an inch long, reddish-purple (greenish outside), in short and somewhat irregular, four- to eight-blossomed clusters that are seldom as long as the leaves. Standard, broader than the other petals. Keel, nearly straight, its petals slightly joined above. Calyx, four-cleft; teeth sharp, entire, the upper one broadest. Stamens, in two sets. Style, beardless.

Leaflets, usually three, five sixths of an inch to one and two thirds inches long, with short stems, oblong or egg-shape, often notched at both ends, slightly hairy beneath. Stipels, present:

Pod, one and a half inches long, very narrow, flat, slightly curved erect, rather hairy. Seeds, four to six. A legume.

Found, in sandy woods from New York southward.

A prostrate, herbaceous vine, perennial, with a smooth or minutely downy stem two to four feet in length. 


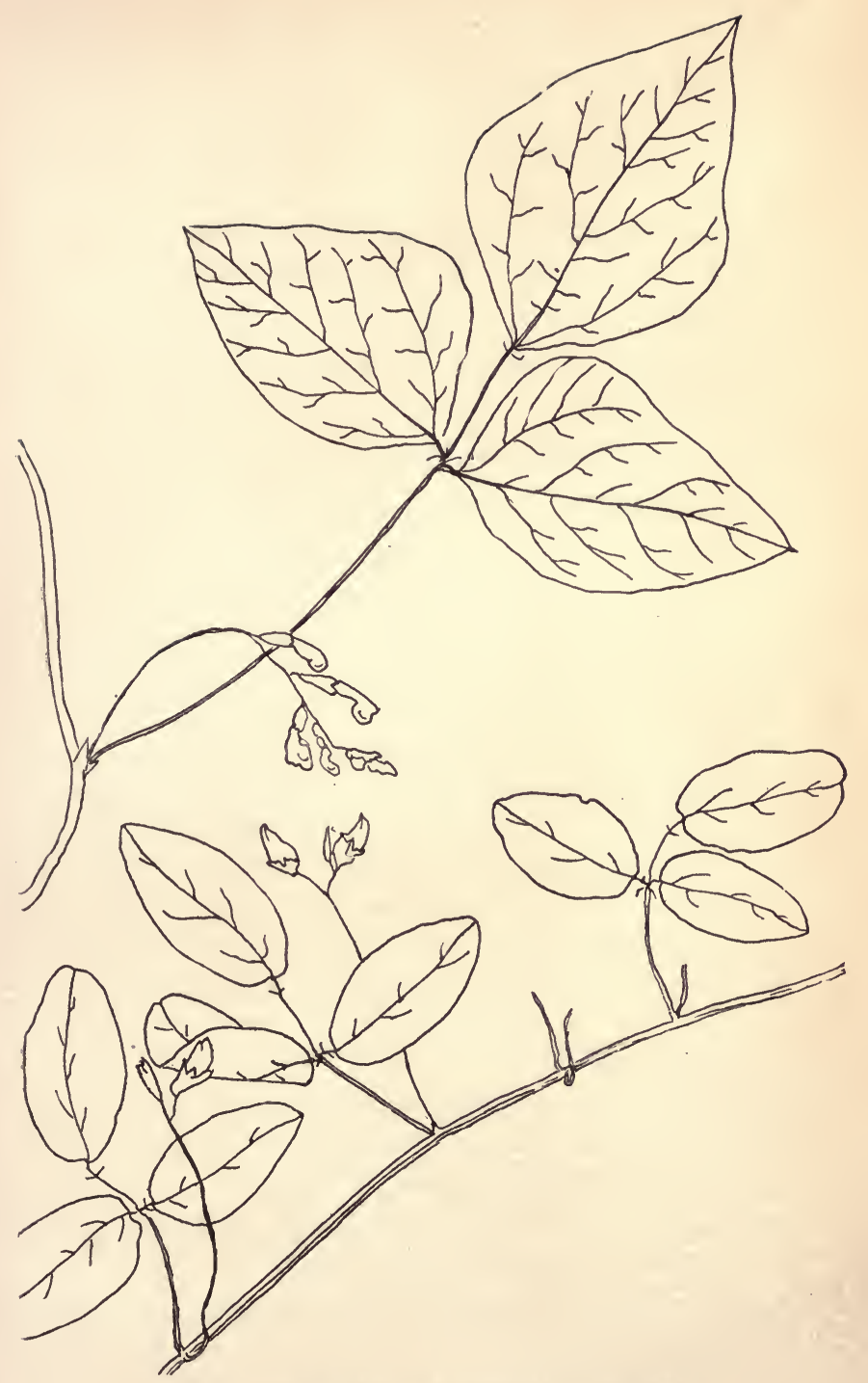

Fig. 24.-Hog-Peanut. A. commòsa (L.), Riddell.

53 Fig. 25.-Milk-Pea. G. regulàris (L.), B. S. P. 
Leaf resembling Fig. 25.-Downy Milk-Pea. G. pilosa, Ell.

This species differs from the preceding chiefly in these items :

Flowers, in many-blossomed clusters that are usually longer than the leaves, sometimes four to six times as long.

Leaflets, half to one inch in length, oval, whitish-downy beneath.

Pods, very downy. Seeds, ten.

Found, from Pennsylvania southward.

(7) Genus Ápios, Boer.

From a Greek word meaning " pear," with reference to the shape of the tubers.

Fig. 26.-Ground-Nut. Wild Bean. A. tuberòsa, Moench.

Flowers, brownish-purple, fragrant, in short, compact, and often branching axillary clusters that are shorter than the leaves. Standard, very broad, and turned back. Keel, scythe-shape, becoming coiled. Calyx, bellshape, slightly two-lipped, the two upper teeth rounded and very short, the two at the sides nearly obsolete, the lower one longest and pointed. Stamens, in two sets (nine united toward the base, and one distinct). July and August.

Leaflets, three to seven (usually seven, rarely three), narrow, egg-shape, more or less pointed, smooth, with short stem. Stipels, lacking.

Pod, slender, nearly cylindrical, straight or slightly curved. Seeds, many, black. A legume.

Found, in damp ground, from New Brunswick to Florida and westward. 
A perennial twining and climbing vine, smooth, herbaceous. It bears edible tubers, of an oval shape. They are somewhat potato-like, and are said to be very nutritious. The stem is round and two to four feet in length.

(8) Genus Vícia, Tourn. (Vetch, Tare.)

Flowers, axillary. Standard, notched. Wings, adhering to the keel. Calyx, tubular, five-cleft or five-toothed, the two upper lobes shortest. Stamens, in two sets (nine more or less united at the base, and one distinct). Style, thread-like (not flattened as in Láthyrus) bent at right angles to the seed-case, bearded by a tuft or ring of hairs at the apex.

Leaves, compound, alternate. Leaflets, in four to twelve pairs, edges entire. Tendrils, at the ends of the leaves-a continuation of the common leaf-stem. Stipules, half arrow-shaped at their base.

Pod, flat oblong. Seeds, two to several (or many in V. Americàna), globular. A legume.

Herbaceous vines, more or less climbing by help of the tendrils.

Fig. 27.-Common Vetch. Tare. [V. sativa, L.]

Flowers, violet-purple, nearly stemless, in clusters of one or two blossoms from the axils of the leaves. Corolla, half an inch long. Cluster-stems, shorter than the leaves. June.

Leaflets, five to seven pairs, two thirds inch to one inch in length, from reverse egg-shape to very narrow. Apex, notched and bristle-tipped.

Fod, slim, erect, smooth, one to two inches in length. Seeds, several. A legume. 


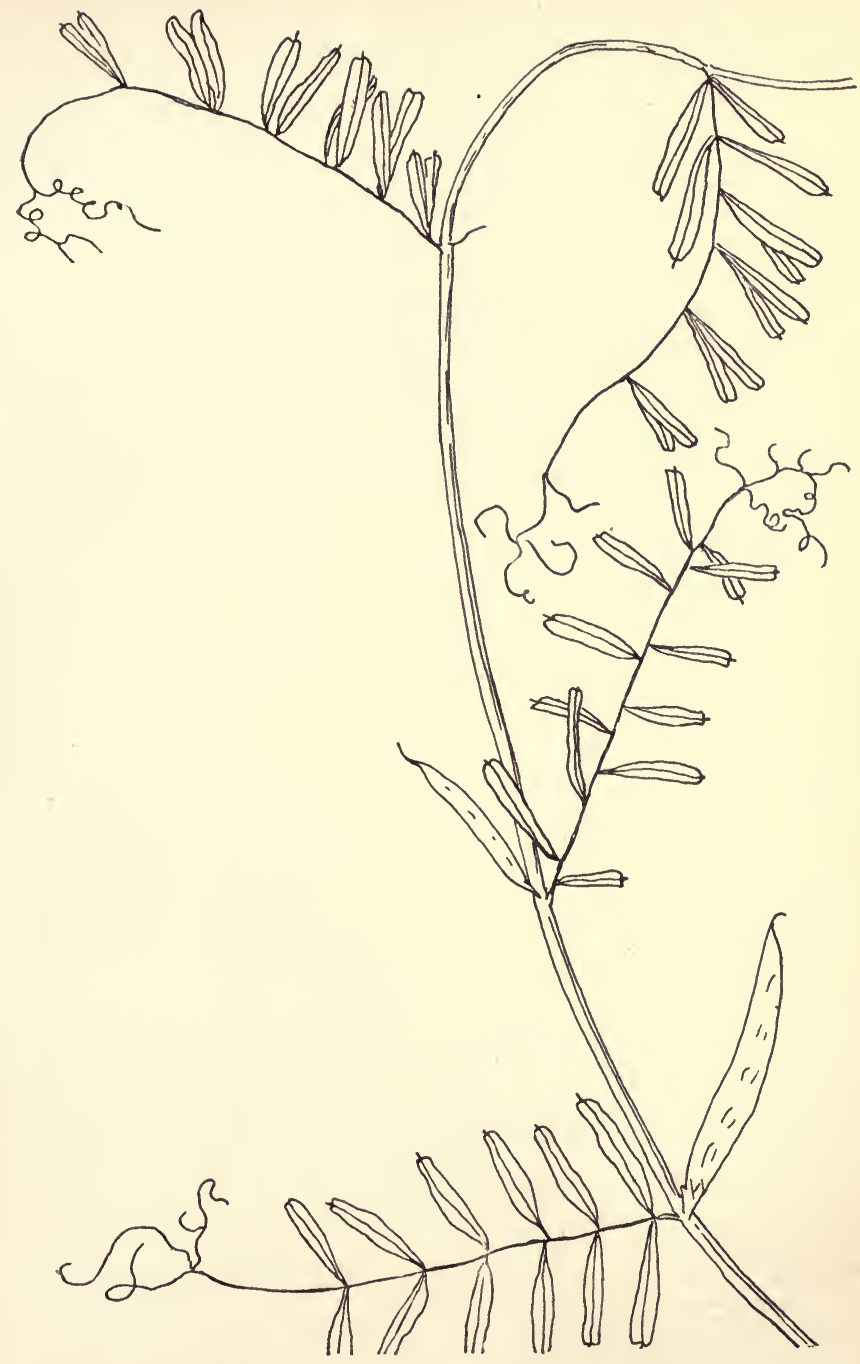

Fig. 27.-Common Vetch. [V. sativa, L.] 
Found, in cultivated fields and in waste ground from New England southward and westward.

A somewhat downy vine, two to three feet long, with a simple herbaceous stem. Introduced from Europe.

The Narrow-Leaved Vetch [var. angustifolia, Ser.] has the leaflets somewhat longer than in the type, and narrow.

Fig. 28.-Four-Seeded Slender Vetch. [V. tetraspérma, L.]

This species differs from the preceding (V. sativa, L.) chiefly in these items :

Flowers, very small, whitish. Cluster-stems, very slender, in flower shorter than the leaves, in fruit longer than the leaves.

Leaflets, (four to six pairs, sometimes three), one half to five sixths inch long, by one twelfth inch wide. July.

Pod, one third to one half inch long. Seeds, four. Found, near the coast from Nova Scotia to New Jersey.

Delicate vines with very slender, almost thread-like stems one to two feet long.

\section{Resembling Fig. 27.-Hairy Vetch. V. hirsìta, Koch.}

This specie differs from the Common Vetch (V. sativa, L.) chiefly in these items :

Flowers, small in clusters of three to six blossoms. Corolla, bluish-white. Cluster-stems, about the length of the leaves. Calyx, with the teeth equal. June. 


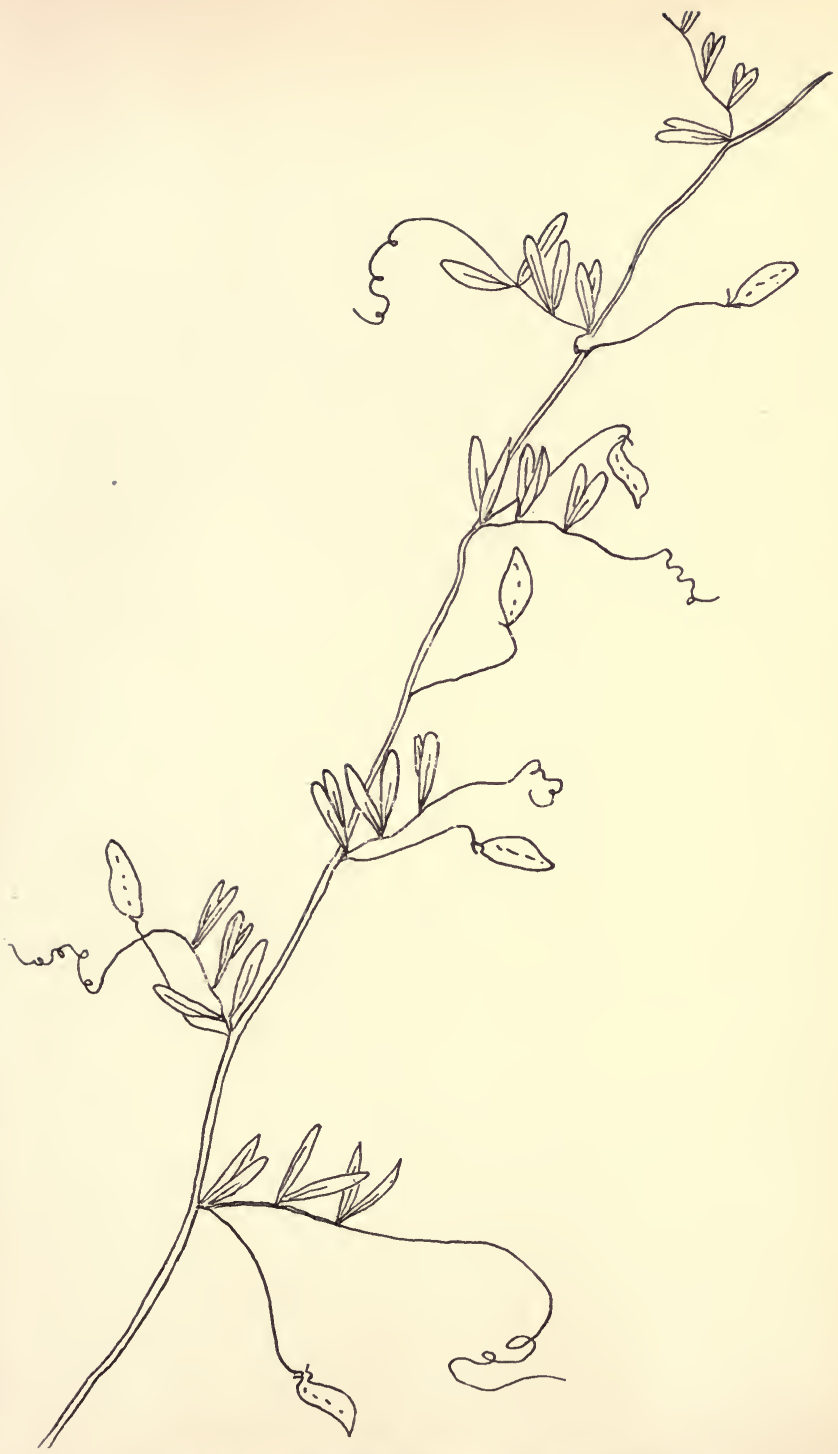

59

Fig. 28.-Four-Seeded Vetch. [V. tetraspérma, L.] 
Leaflets (six to eight pairs), a quarter to two thirds inch long, scarcely one twelfth inch wide, widest above, with the apex squared.

Pod, short, hairy. Seeds, two.

Found, from New York to South Carolina.

A hairy, very slender creeping vine one to three feet in length.

Fig. 29. - Tufted Vetch. V. crácca, $L$.

Flowers, many, twelve to twenty or more in a long, densely blossomed, one-sided cluster; blue, becoming purple, one half inch in length, reflexed. Calyx, with its teeth unequal and shorter than its tube. Clusterstem, lengthened. July.

Leaflets (ten to twelve pairs), one half to two thirds inch long by one sixth to one quarter inch wide with short stems, oblong to lance-shape, strongly bristle-pointed, downy.

Pod, several-seeded.

Found, from Newfoundland to New Jersey.

A slender climber, slightly downy, with square stem, two to three feet in length.

Fig. 30.-Carolina Vetch. V. Caroliniàna, Walt.

Flowers, small (one quarter inch long or a little more), whitish, in loose clusters of six to twelve blossoms. Keel, tipped with blue. Calyx, teeth unequal, the two upper very short. Cluster-stem, usually rather shorter than the leaves. May.

Leaflets (four to eight pairs), half to one inch in length, mostly alternate, oblong or narrow. Apex, rounded, slightly pointed, or sometimes notched. 


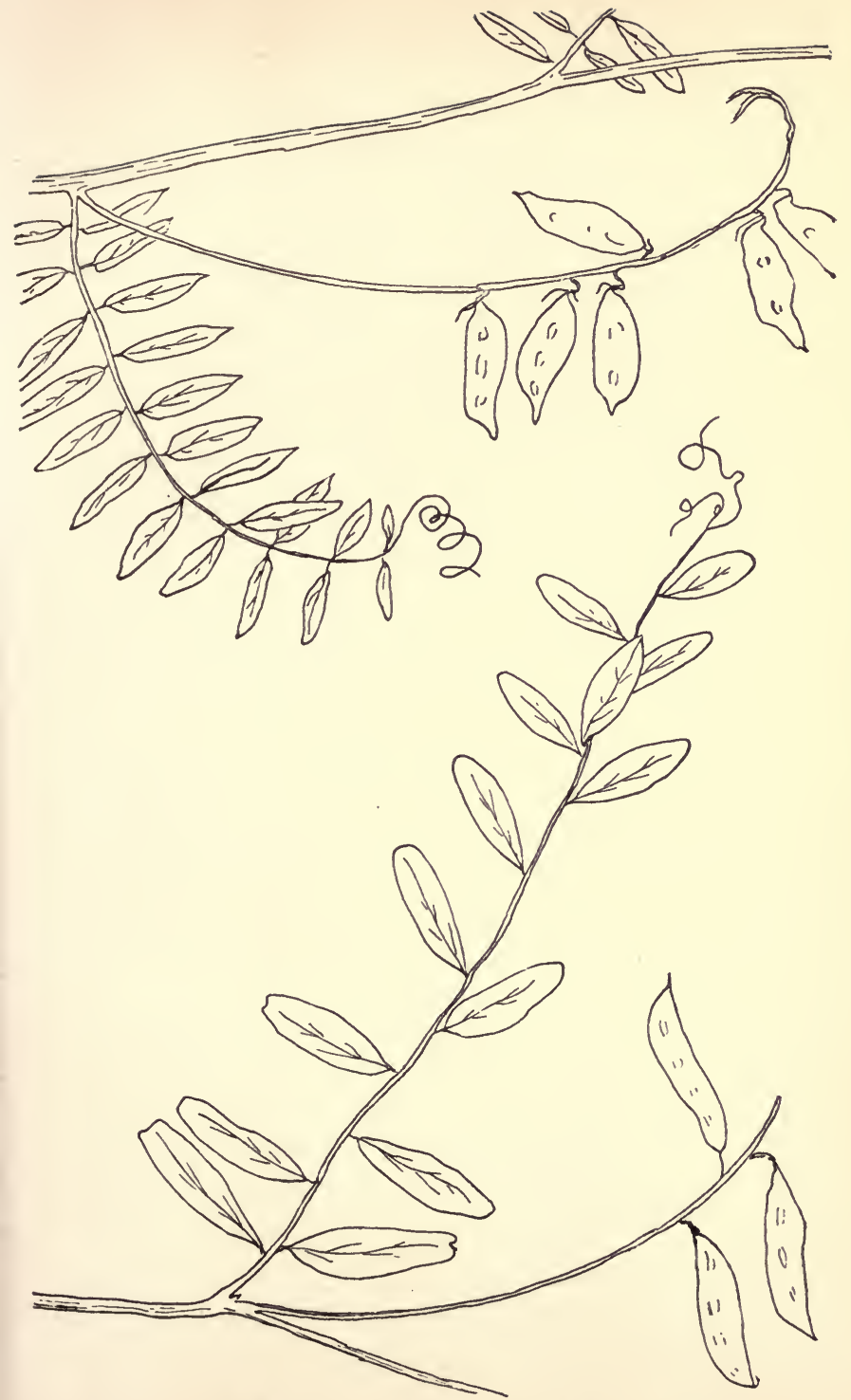

Fig. 29.-Tufted Vetch. (V. crácca, L.)

Fig. 30.-Carolina Vetch. (V. Caroliniàna, Walt.) 
Pod, oblong. Seeds, several.

Found, from Ontario and New York to Georgia, and westward to Minnesota and Kansas.

A slender, nearly smooth climber, four to six feet high with branching stems.

Fig. 31.-American Vetch. V. Americàna, Muhl.

Flowers, purplish, two thirds inch in length, in clusters of four to eight blossoms. Calyx, teeth unequal, the lower broad, lance-shape, and much longer than the upper. Style, very hairy at the apex. Cluster-stems, shorter than the leaves. May.

Leaflets (five to seven pairs), very blunt, five sixths to one inch long, nearly stemless.

Pod, many-seeded.

Found, in moist ground from New York and New Jersey westward.

A slender, smooth vine, one to three feet in length.

(9) Genus LÁthyrus, Tourn. (Vetchling. Everlasting Pea.)

This genus closely resembles the preceding (Vicia). It has the characteristic arrangement of tendrils, at the end of the compound leaf; but it differs in having the style flattened, and bearded on the side toward the banner (and toward the free stamen), and in its usually few leaflets, -one to six pairs.

The Sweet Pea [L. odoràtus, L.], one of the best-loved of our garden flowers, belongs with this genus. It is a native of Sicily. 


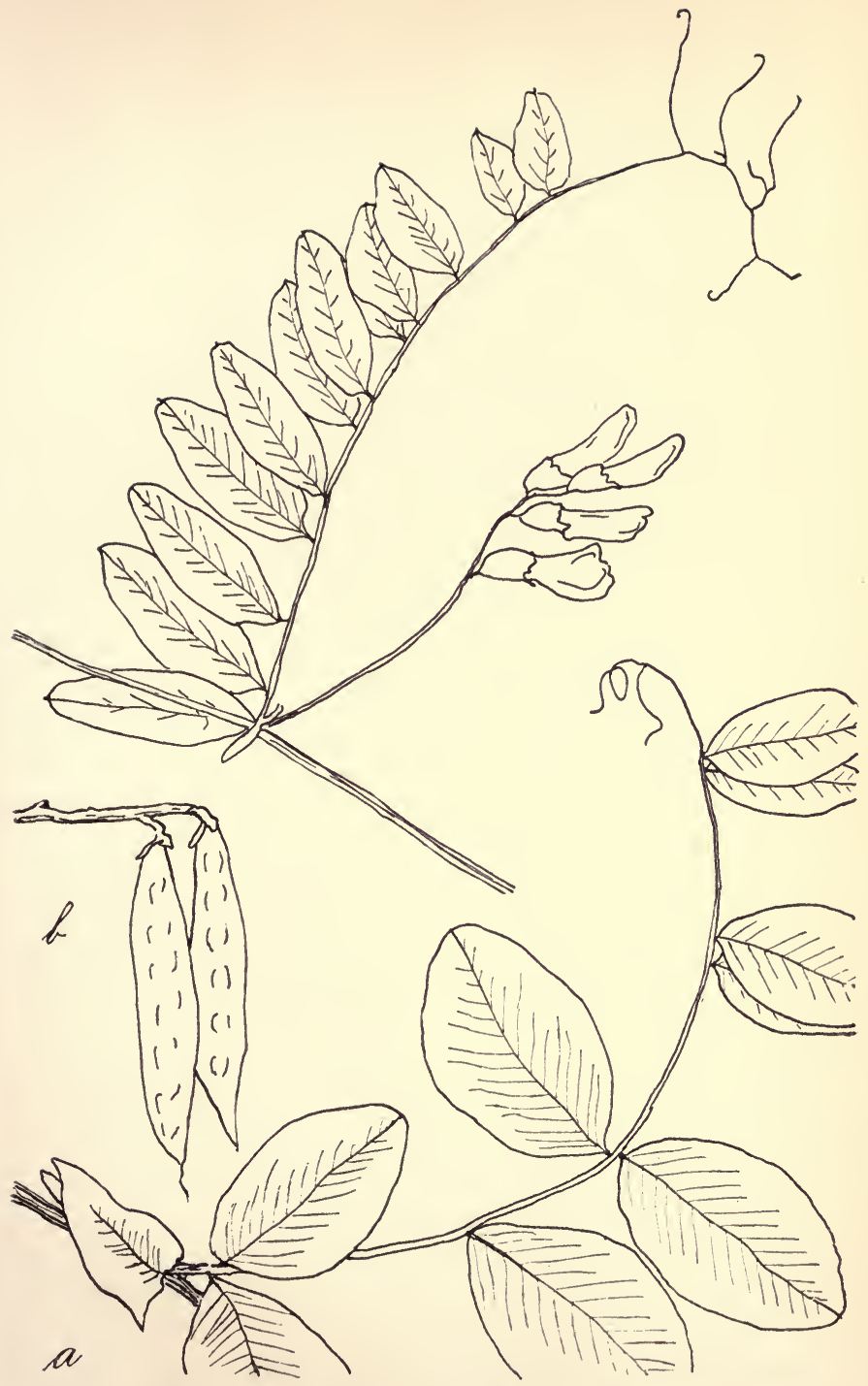

Fig. 31.-American Vetch. (V. Americàn3, Muhl.) Fig. 32.-Beach-Pea. (L. marítimus, Big.) $a$. Leaf with stipules. $b$. Fruit. 
Fig. 32.-Beach-Pea. L. maritimus, Big.

Flowers, purple or blue, three quarters inch in length, in clusters of six to ten blossoms. Cluster-stems, rather shorter than the leaves. May and July.

Leaflets, three to five pairs (oftenest five), with the lower pairs largest, one to two inches long, thick, egg-shape to oval. Stipules, nearly as large as the leaflets, united, broad egg-shape, at the base heart-shaped, with one lobe larger than the other, and oftenest coarsely toothed.

Pod, several-seeded.

Found, along the sea-shore from New Jersey to the Arctic Ocean, and on the lakes.

A stout creeper, smooth or nearly so, with a fourangled stem, one to two feet in length, resembling the pea-vine of the gardens.

Fig. 33.-Yellow-White Vetchling. L. ochroleùcus, Hook.

Flowers, yellowish-white, in clusters of seven to ten blossoms. Cluster-stems, shorter than the leaves. June, July.

Leaflets, three to five pairs (oftenest three), one to one and a half inches long, thin, egg-shape to oval. Stipules, half heart-shape, often half the size of the leaflets.

Pod, several-seeded.

Found, from New Jersey to Iowa, and northward to the Arctic Circle.

A slender-stemmed climbing vine, smooth or nearly so, one to three feet in length. . Rare. 


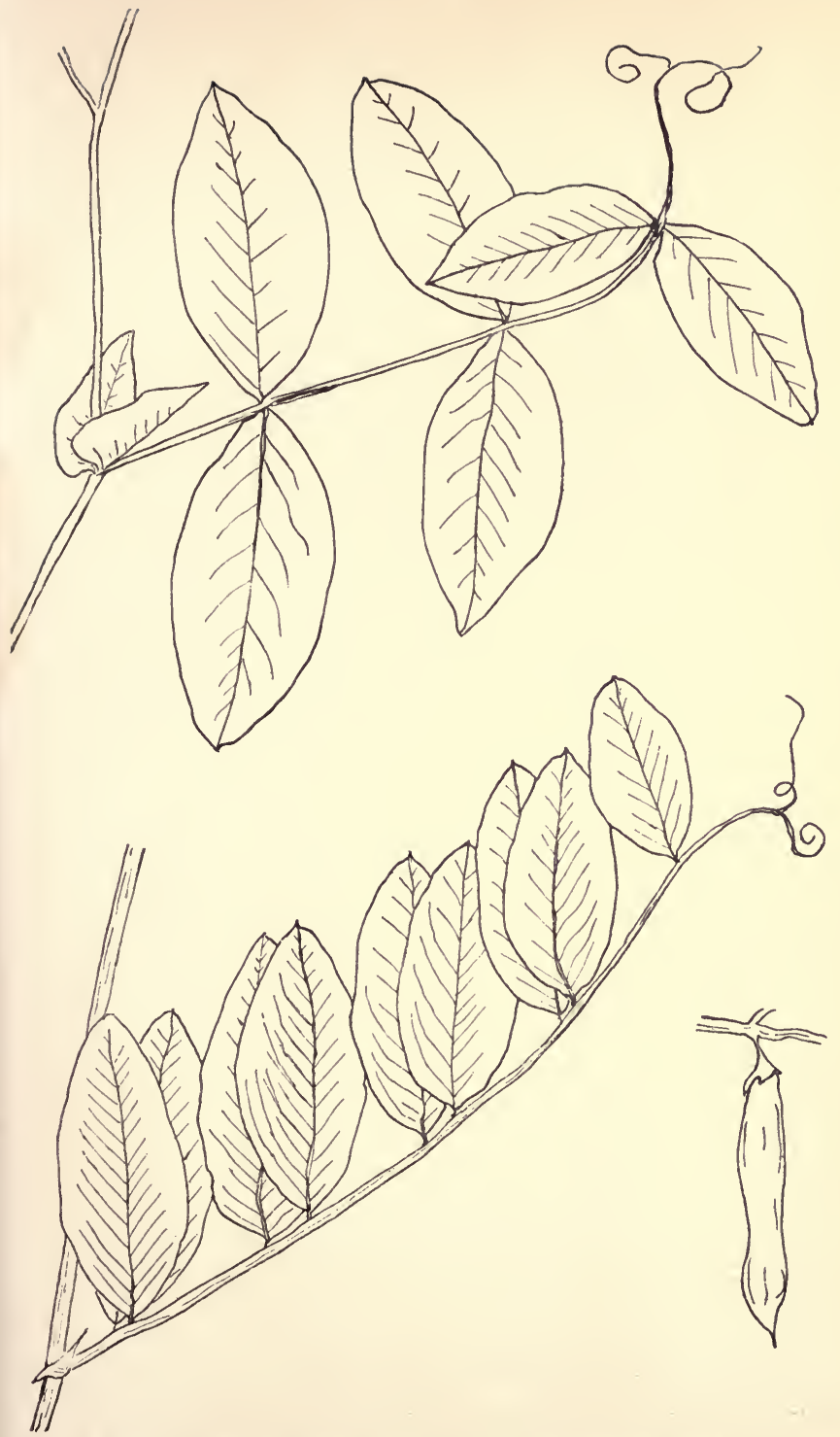

Fig. 33.-Yellow-White Vetchling. (L. ochroleùcus, Hook.)

Fig. 34.-Veiny Vetchling. (L. venòsus, Muhl.) 
Fig. 34.-Veiny Vetchling. L. venosus, Muhl.

Flowers, purple one half to two thirds inch long, in many-blossomed clusters. Cluster-stems, three to five inches in length. Calyx, teeth very unequal. June, July.

Leaflets (four to six pairs), one and a half to two inches in length, egg-shape to long oval. Stipules, very small and narrow; at the base, half arrow-shaped; at the apex, pointed.

Pod, flat and narrow, several-seeded.

Found, in shady places from Georgia to Mississippi and northward.

A stout climber, smooth or slightly downy. Stem fourangled, two to three feet in length.

Fig. 35.-Swamp Vetchling. L. palistris, $L$.

Flowers, purple, sometimes variegated with blue and purple; one half inch or more long, in clusters of two to six blossoms. Cluster-stems, longer than the leaves.

Leaflets, two to four pairs, one to two inches in length, narrow or line-like. Apex, pointed. Stipules, lanceshape, with apex and base pointed. June and July. Found, in moist ground from Nova Scotia to New Jersey and westward across the continent.

Pod, several-seeded.

A slender climber, smooth or nearly so, the square stem oftenest broadly winged at the angles, two to four feet in length.

The variety called Myrtle-Leaved Vetchling (var. myrtifolius, G.; L. myrtifolius, Muhl.) has the leaflets egg- 


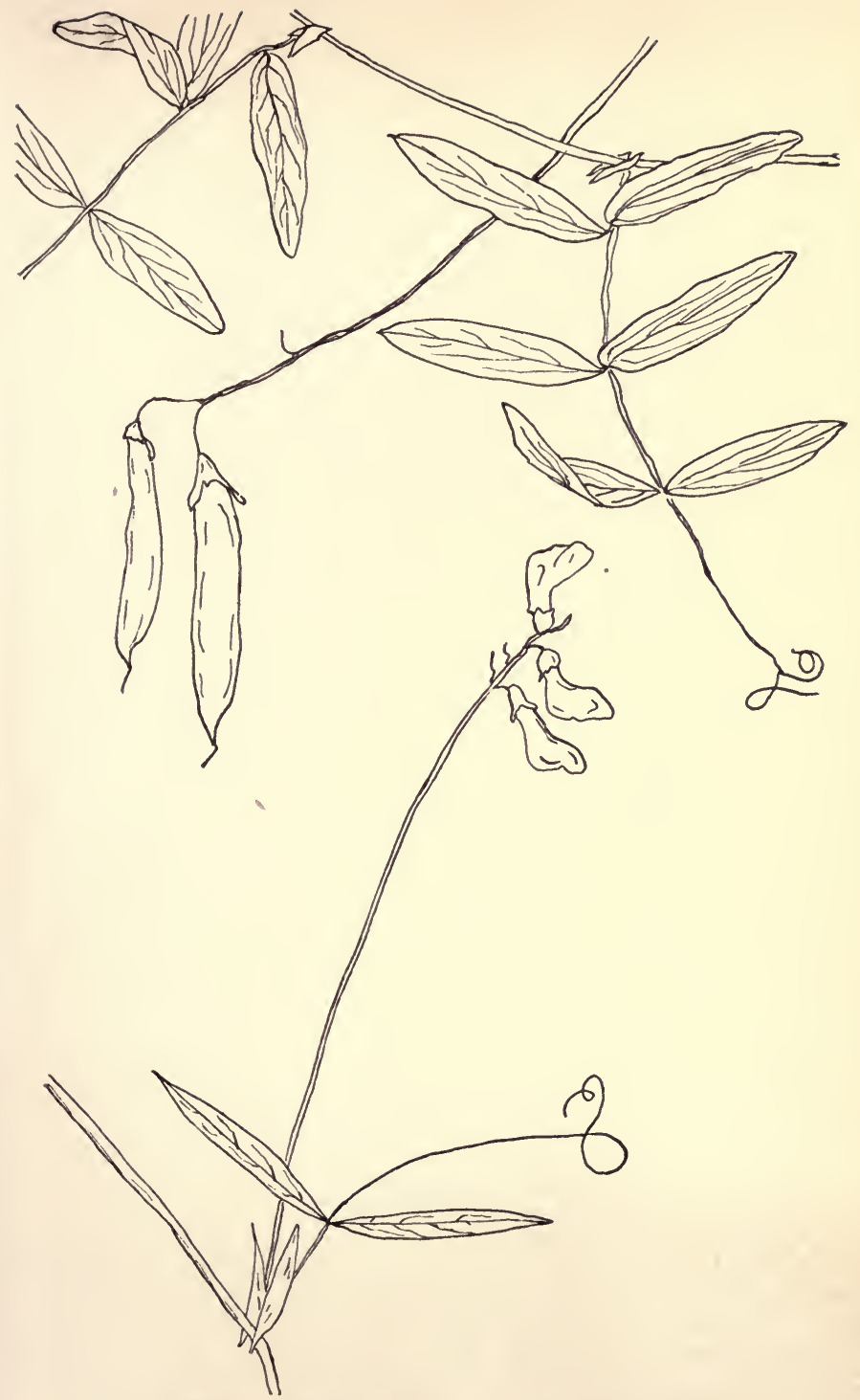

Fig. 35.-Swamp Vetchling. (L. palústris, L.)

Fig. 36.-Spreading Vetchling. [L. praténsis, L.] 
shape to oblong, one inch or less in length, with the stipules usually larger and broader than in the type, and with the stem often only slightly winged. It is found as far south as North Carolina.

Fig. 36.-Spreading Vetchling. [L. praténsis, $L$.

Flowers, yellow, in few-blossomed clusters.

Leaflets, one pair, narrow, lance-shape to line-like. Apex, pointed. Stipules, half arrow-shape, half the length, or more, of the leaflets.

Found, in Massachusetts, New York, and Ontario.

A low, straggling vine introduced from Europe.

\section{No. 8.-Family ROSÀCEÆ. (Rose Fam.)}

Flowers, regular. Petals, not united, inserted with the stamens on the edge of a disk that lines the tube of the calyx. Sepals, united toward the base, often accompanied outside by a row of small leaf-like bracts. Stamens, numerous, inserted as above. Seed-cases, several to many, free from the calyx excepting in Genus Rosa (4) where the many seed-cases are embedded in the inner surface of the more or less rounded calyx-tube.

Leaves, compound, except in Dalibárda (2), alternate, edges toothed.

Fruit, seed-like drupes, drupelets, or achenes.

GUIDE TO GENERA.

(a) Flowers, white.

(b) Leaves, compound. Fruit, a collection of fleshy drupelets. (I) Rùbus (Blackberry. Raspberry).

(b) Leaves, simple. Fruit, a collection of nearly dry, seed-like drupes. (2) Dalibárda (False Violet). 
(a) Flowers, yellow. Leaflets, three (apparently five, by the parting of the side leaflets). Fruit, a dry head of achenes. (3) Potentílla (Cinquefoil).

(a) Flowers, rose, changing to white. Leaflets, three to five. Fruit, globular, enclosing bony achenes. (4) Ròsa (Rose).

(1) Genus Rùbus, Tourn. (Raspberry. Blackberry.)

From a word meaning " red."

Flowers, white. Petals, five distinct, soon falling. Sepals, five, partly united, spreading. Stamens, numerous, on the edge of the disk. Seed-cases, many, each with two young seeds, only one of which ripens, crowded on a lengthened fleshy receptacle.

Leaves, compound. Stems, armed with prickles, except in Dwarf Raspberry (R. triflòrus, Rich).

Fruit, a pulpy, edible "berry," so called, formed by the ripened seed-cases; really, a mass of small drupes.

Leaf resembling Fig. 37.-Dwarf Raspberry. R. triflorus, Rich.

Flowers, white, one to three on a slender stem. Petals, small, erect, slightly longer than the sepals. Petals and sepals often six or seven.

Leaflets, three or five, one to two inches long, doubletoothed, thin and nearly smooth.

Stem, slightly woody or herbaceous, with herbaceous branches, short (six to twelve inches), without prickles, ascending or trailing.

Fruit, rather sour, dark red, of a few disconnected grains, which, when ripe, separate from the receptacle.

Found, from New Jersey northward and westward, in moist woods. 
Fig. 37.-Low Blackberry. Dewberry. R. Canadénsis, L.

Flowers, with leaf-like bracts, in clusters, on slender, solitary cluster-stems. Petals, large, reverse egg-shape, twice as long as the sepals. May.

Leaflets, three (rarely five or seven), one to one and a half inches long, nearly stemless, oval to broad lance-shape, nearly smooth.

Fruit, black, half to one inch in diameter, very juicy and sweet, not separating when ripe from the lengthened receptacle. A collection of drupelets. July and August.

Found, common in dry open ground from Newfoundland to Virginia, and westward.

A woody vine with valuable fruit. Stem somewhat prickly, and trailing extensively.

Leaf resembling Fig. 37.-Running Swamp Blackberry ( $R$. hispidus, L.).

Flowers, small, in clusters of several to many blossoms. Cluster-stems, often bristly.

Leaflets, three (rarely five), one to two inches in length or smaller on the branchlets. Edges, toothed, entire toward the base. Apex, pointed or on the branchlets sometimes blunt. Base, mostly rounded, or on the branchlets sometimes pointed.

Fruit, black, of few grains, sour.

Found, in swampy or low ground from Nova Scotia to Georgia and westward.

A slender vine, scarcely woody; trailing several feet, with more or less erect branches eight to twelve inches high. The main stem and the larger leaf-stems are armed 


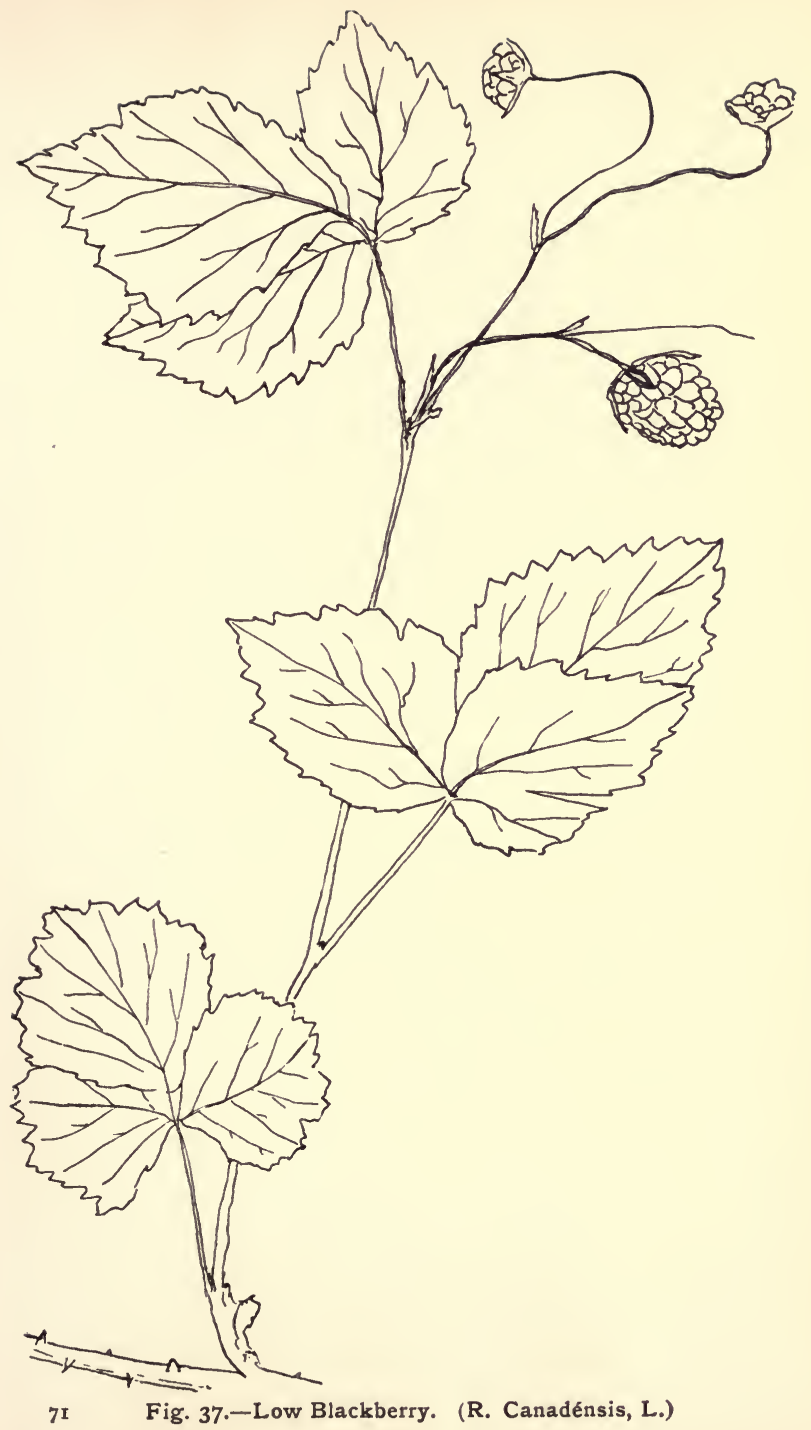


with small, reflexed, bristle-like prickles. The leaves are mostly persistent through the winter.

\section{(2) Genus Dalibárda, L.}

From the name of a French botanist.

Fig. 38.-False Violet. D. rèpens, $L$.

Flowers, white, one (or sometimes two) on a long stem. Petals, five, soon falling, reverse egg-shape, longer than the sepals. Calyx, deeply five- or six-parted, with three of the lobes longer than the others, and toothed; spreading in flower, but closing around the seed-case in fruit. Stamens, many. Styles, five to ten, long. Seed-cases, five to ten. June, August.

Leaves, simple, rounded, one to two inches in diameter. Edge, blunt-toothed; downy. Base, heart-shape. Apex, blunt. Leaf-stem, slender, one to three inches in length.

Fruit, a head of nearly dry, seed-like drupes.

Found, common in low woods from Pennsylvania to Canada.

A low, perennial herb, downy, with creeping, closelytufted stems, one to twelve inches in length.

\section{(3) Genus Potentílla, L.}

From a word meaning " powerful," because of the supposed medicinal qualities of one of the species.

Fig. 39.-Cinquefoil. Five-finger. $P$. Canadénsis, $L$.

Flowers, yellow, solitary, on long axillary stems. Petals, five, rounded, or reverse heart-shape, as long as the calyx. Calyx, spreading, deeply five-cleft, with five bractlets between the lobes, so appearing to be tencleft. Stamens, many, with slender filaments. April to August. 

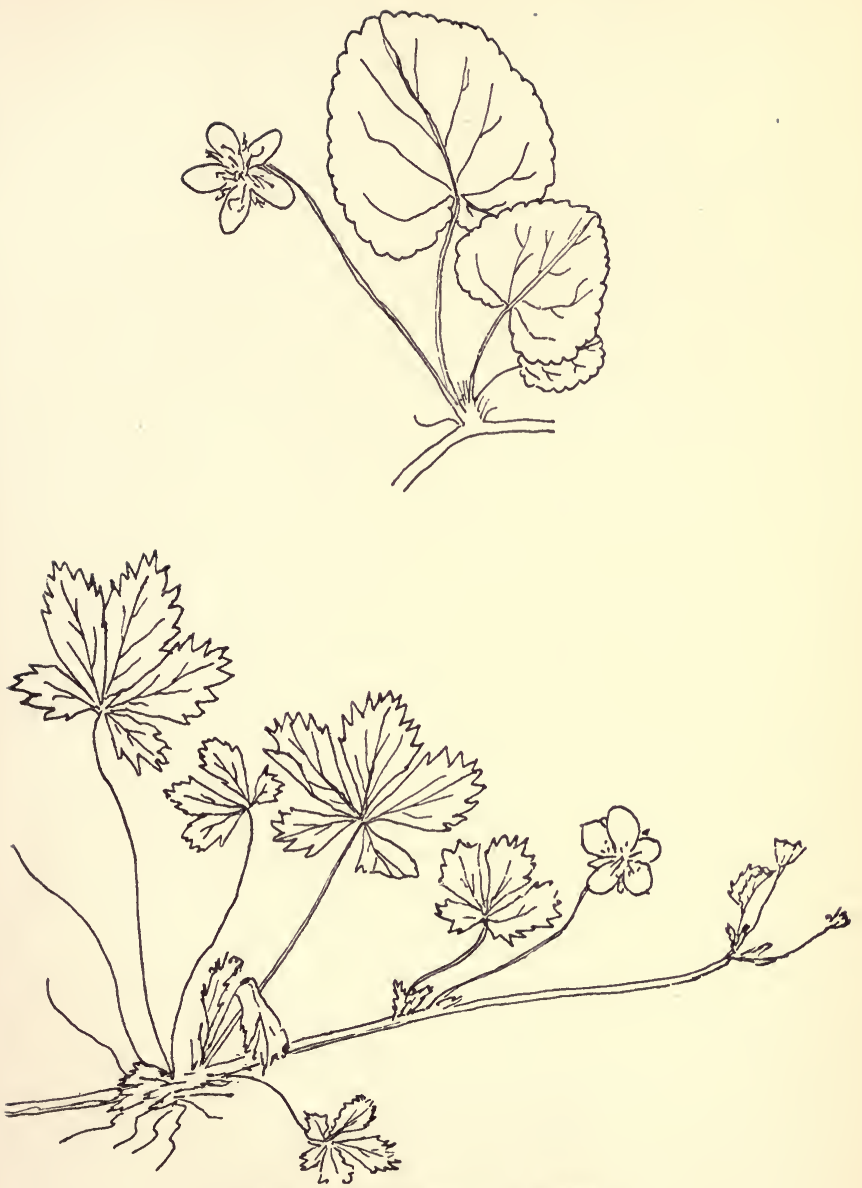

Fig. 38.-False Violet. (D. rèpens, L.)

Fig. 39.-Cinquefoil. (P. Canadénsis, L.) YOUNG LEAVES. 
Leaves, variable in size, compound, with radiating leaflets. Leaflets, three, but apparently five by the dividing of the side leaflets; somewhat wedge-shape or reverse egg-shape, toothed, nearly smooth above. Very rarely there may be seven apparent leaflets. Stipules, hairy, often divided.

Fruit, a head of smooth achenes on a dry, very hairy receptacle.

Found, common in dry soil, in Canada and the United States.

A slender prostrate vine, perennial, herbaceous, more or less hairy ; from a few inches in length to a foot or more; often spreading by runners.

A seven-leaved cinquefoil shares with the four-leaved clover its reputation for magical virtues. Let the finder sleep with it beneath her pillow, and, if its reputation is deserved, "she will dream of the lover whom she is to have, as sure as the dead man lies in his grave."

\section{(4) Genus Ròsa, Tourn.}

Fig. 40.-Climbing Rose. Prairie Rose. Michigan Rose. R. setigera, $M x$.

Flowers, two to three inches across, in clusters, only slightly fragrant. Petals, five, deep rose color, changing to white. Calyx and stalks dotted with small glands. Sepals, pointed, Styles, united in a protruding column as long as the stamens. July.

Leaflets, three to five, egg-shape, edges toothed. Apex, pointed.

Fruit, called a " hip," globular with the bony achenes on the inside. 

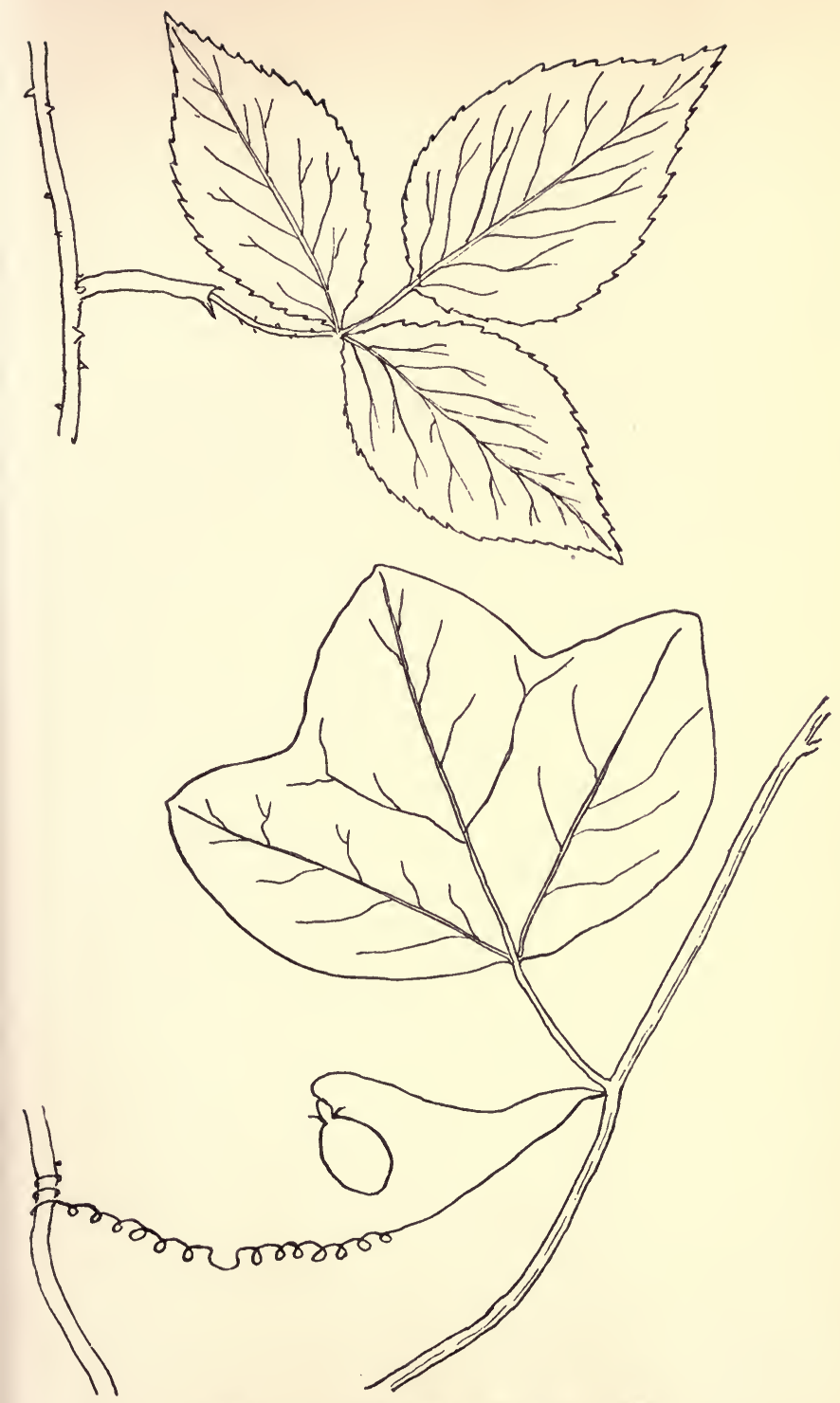

Fig. 40.-Climbing Rose. (R. setígera, Mx.)

Fig. 4I.-Yellowish Passion-Flower. (P. lùtea, L.) 
Found, in damp ground from Ontario to South Carolina and Florida, and west to Wisconsin and Texas; also in cultivation.

An extensively climbing vine, the only native climbing rose of America, as it is the only one also with united and exserted styles. The stems are armed with a few stout prickles. Vigorous shoots sometimes grow from ten to twenty feet in a season. There are about twenty varieties of the species in cultivation; one of them is the favorite Baltimore Belle. No. 9.-Family PASSIFLORÀCE $Æ . \quad$ (Passion-Flower
Fam.)

Genus Passiflòra, L.

From words meaning "passion" and "flower" because of a fancied resemblance in the parts of the flower to the implements of the Crucifixion.

Fig. 4I.-Yellowish Passion-Flower. P. littea, $L$.

Flowers, greenish-yellow, about one inch across; on jointed stems, solitary or in pairs from the axils of the leaves. Petals, five, not united, inserted on the throat of the calyx. Sepals, five, colored like the petals, at least within ; united toward the base into a shallow cup; the edges of the cup furnished with a delicate triple fringe. Stamens, five, united below so as to form a sheath around the long stem of the seed-case. Anthers, large, balanced at their centres. Styles, three, with club-like stigmas. Seed-case, free, one-celled, many-seeded, raised on a sheathed stem. May, July.

Leaves, simple, alternate, three-lobed toward the apex, heart-shaped at the base; the lobes blunt; edges entire. Stipules, present. Leaf-stems, without glands. 
No. 9] (Passion-Flower Passifloràcea).

Fruit, dark purple, oval, one half inch in diameter; numerous-seeded. A pulpy berry.

Found, in damp thickets from Southern Pennsylvania to Florida, and westward.

A smooth, slender vine, herbaceous, from five to ten feet long, climbing by axillary tendrils.

The Blue Passion-Flower ( $P$. carùlea, L.), often cultivated for its foliage and its showy blossoms, is a native of Brazil.

There it often grows to a distance of thirty feet, with a woody stem four or five inches in diameter.

A southern species, $P$. incarnàta, L., having blossoms two inches or more across with white or purplish petals and crown, and with markings of green and of deeper purple, is well worthy of cultivation. Its fruit (commonly named May-pop) is as large as an egg, and edible. This species is found as far north as Kentucky and Virginia, and in some places is so abundant as to be looked upon as a troublesome weed.

There are some one hundred and twenty species of the Passion-Flower, nearly all of them found only in the Western Continent, and most of them only in the Tropics. Five of them are found in the Atlantic States, but only one of the five (our P. lìtea, L.) as far north as Pennsylvania and Illinois.

The name Passion-Flower was given, probably by the early Spanish missionaries to this country, because the parts of the flower and of the plant serve so strangely well as reminders of the crucifixion of our Lord. In the palmate leaves (less marked in our species than in others) 
they saw the hands of Christ's enemies; in the coiled tendrils, scourges. The delicate spreading rays reminded them of the nimbus, or halo, about $\mathrm{H}$ is head, and of the crown of thorns. The three styles with their stigmas suggested the three nails - two for the hands, and one for the crossed feet; the five anthers, the five wounds, or sometimes the hammers for driving the nails. Also the position of the spreading stigmas was suggestive of the cross itself. The ten parts of the flower stood for the ten disciples, omitting Judas and Peter.

So the flowers, which in many places were very common, came to be constant reminders of the Christ.

No. ı._Family CUCURBITÀCEÆ. (Gourd Fam.)

\section{(I) Genus Sícyos, L.}

The Greek name for the cucumber.

Fig. 42.-One-Seeded Bur-Cucumber. S. angulàtus, $L$.

Flowers, small, whitish; in two forms, both from the same axil: the pistillate form in rounded clusters, the staminate form in lengthened clusters. Petals, five, spreading, united toward the base. Calyx, fivetoothed. Stamens, five. Anthers, united in a single mass. Style, slender. Stigmas, three. Seed-case, onecelled, one-seeded, adherent to the calyx. July to September.

Leaves, three to five inches across, simple, alternate, fiveangled or five-lobed, rounded, heart-shape. Ends of the lobes pointed, edges toothed, the hollows rounded and shallow. Surfaces downy. Leaf-stems, hairy. Tendrils, three-branched or more, the branches in spirals. 


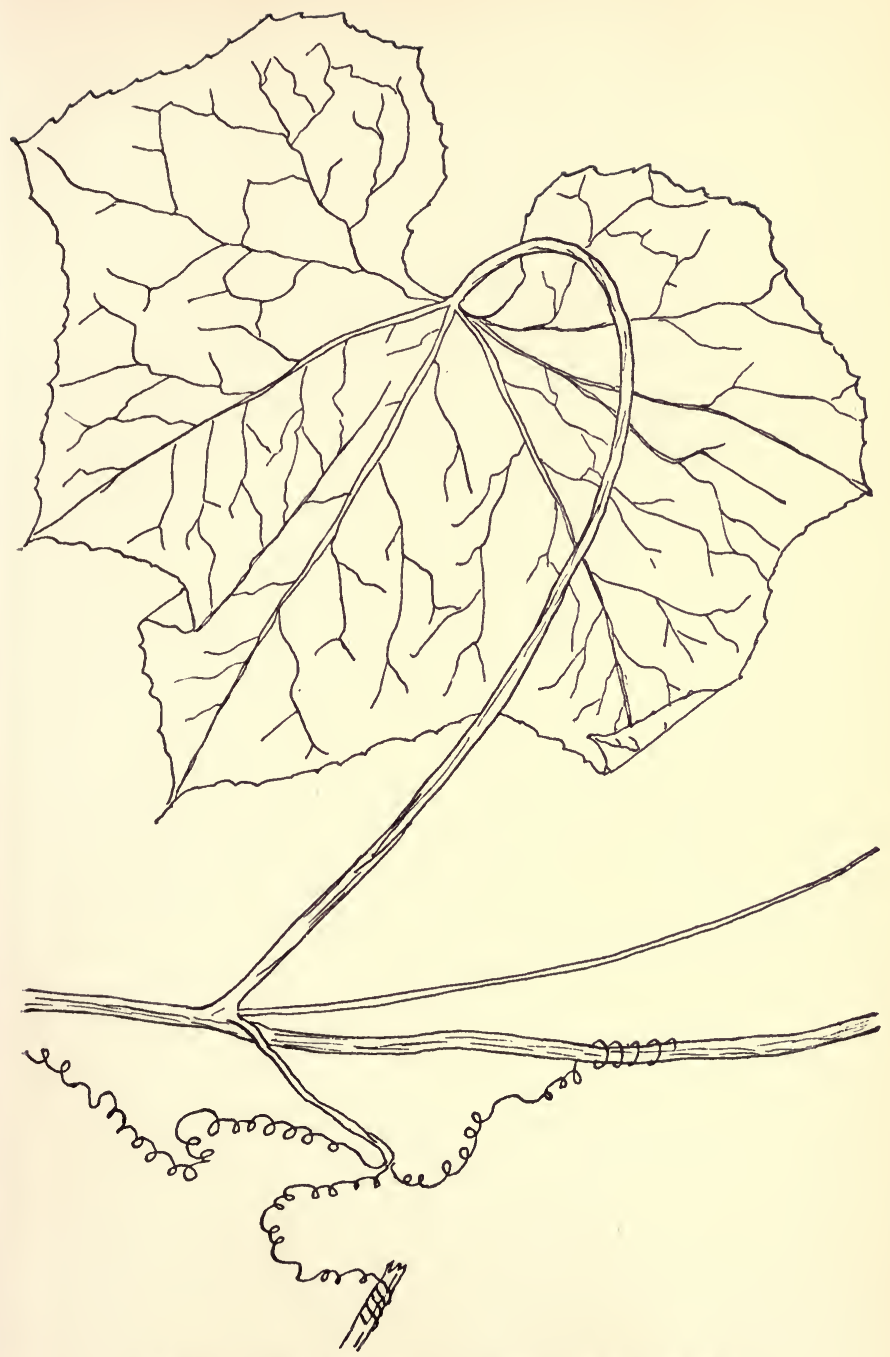

79 Fig. 42.-One-Seeded Bur-Cucumber. (S. angulàtus, L.) 
Fruit, eight to ten cucumbers in a crowded cluster, each egg-shape, one half inch long, becoming dry, not splitting in ripening, filled by the one seed, covered by barbed and easily-detached bristles. A pepo.

Found, in damp and waste places from Canada to Florida and westward.

A weak, hairy vine, herbaceous, with branching stems, climbing extensively by half of its abundant forked and spiral tendrils. It is useful in cultivation for screens.

The spiral contraction of a tendril after it has caught a support is in various ways of high service to the plant. Sometimes it serves to lift it toward the light. Always it makes the hold of the plant more elastic, and therefore safer, as the hold of a ship at anchor is made safer by a twisted rope than it could be by a straight wire. The pretty plant-ships are struck by a gale of wind, roughly as a fleet of men-of-war in the Bay of Biscay. Do they founder before it? No, they rock and roll, and the tiny cables stretch, but will not break. If anything yields, it will be the anchorage, not the cables.

"When a tendril has caught a support, and is spirally contracted, there are always as many turns in one direction as in the other, so that the twisting of the axis in one direction is exactly compensated by the twisting in the other."-DaRwin.

Commonly there is but one change of direction in the coil, and that at the centre, but whether one or as many as seven or eight, always the total turns in one direction are as many as in the other. 
Darwin shows the principle of this motion by a familiar example :

"When a haberdasher winds up a ribbon for a customer he does not wind it into a single coil, for if he did the ribbon would twist itself as many times as there are coils [turns], but he winds it into a figure eight on his thumb and little finger, so that he alternately takes turns in opposite directions, and thus the ribbon is not twisted. So it is with the tendrils, with this sole difference-they take several consecutive turns in one direction, and then the same number in an opposite direction, but in both cases the self-twisting is avoided."-Dariwin's Climbing Plants.

So also the housemaid, to avoid snarling her long clothes-line, winds it into a figure eight between her hand and her elbow.

[See further concerning tendrils under Vitis, pages 18 , 19.]

(2) Genus Micrámpelis, Mx. (Echinocýstis, T. and G.)

Fig. 43.-Wild Balsam-Apple. M. lobàta (Mx.), Green.

Flowers, very small, greenish-white; in two forms, both from the same axil ; the pistillate form in small clusters or solitary, the staminate form in lengthened compound clusters, often one foot in length. Petals, six, spreading, united at the base. Sepals, six, slender, shorter than the petals. Stamens, three. Style, very short. Stigmas, two, large. Seed-case, two-celled, four-seeded. July to September. 
Leaves, simple, alternate, thin, deeply five-lobed. Base, heart-shape. Tendrils, three-forked.

Fruit, oval, two inches long, fleshy, becoming dry, covered with weak prickles, two-celled, opening at apex when ripe. Seeds, four, large, flat, dark. A pepo.

Found, in rich soil from Canada to Pennsylvania, Eastern Kansas and Texas.

An extensively climbing, herbaceous annual, nearly smooth, with abundant foliage, useful for screens and arbors.

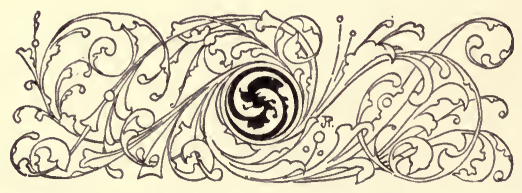




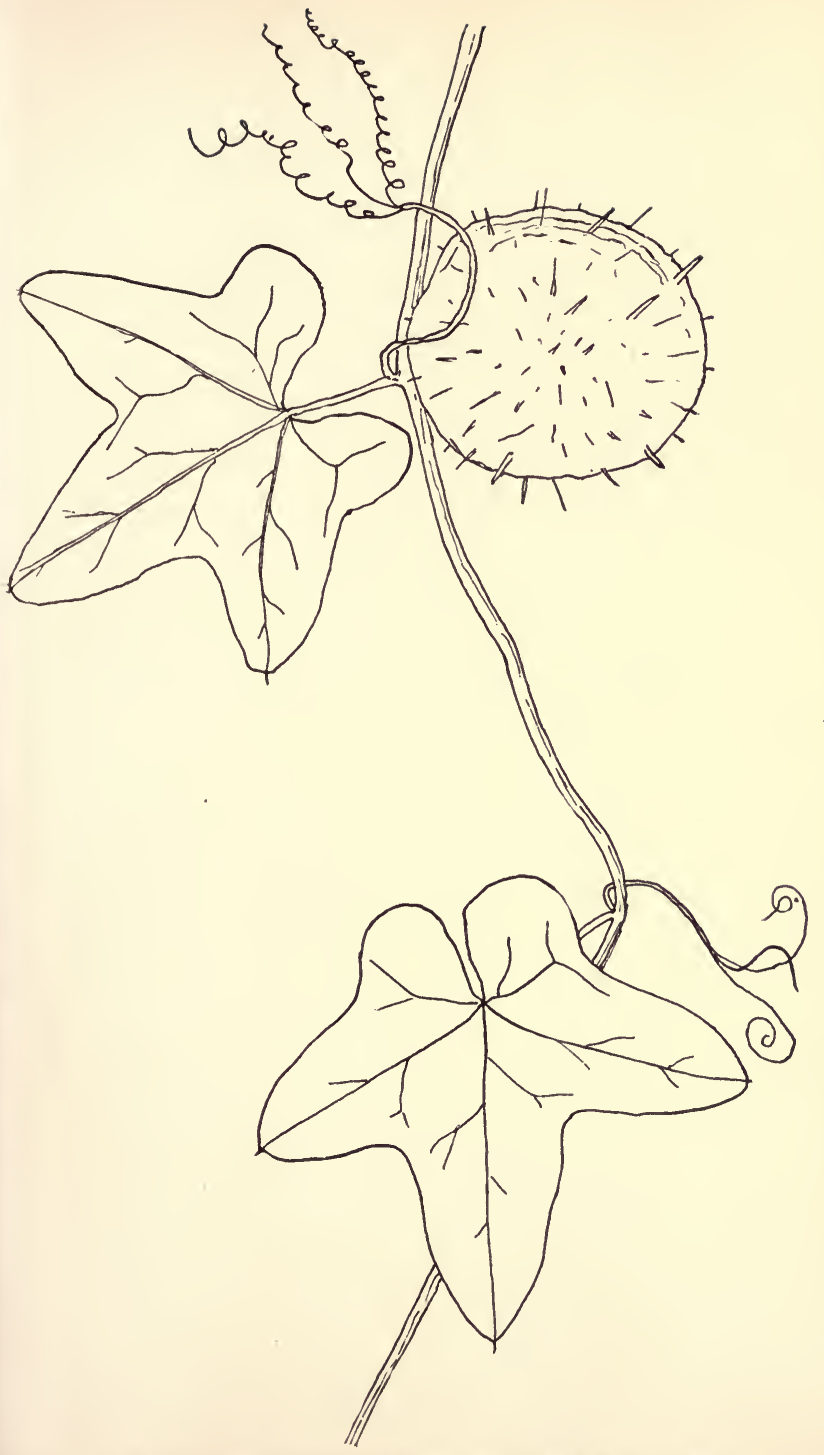

Fig. 43.-Wild Balsam-Apple. M. lobàta (Mx.), Green. 



\section{CLASS FIRST-Continued}

(EXOGENS)

\section{DIVISION II}

CALYX AND COROLLA USUALLY BOTH PRESENT-THE LATTER OF UNITED PETALS

(GAMOPÉTALOUS) 



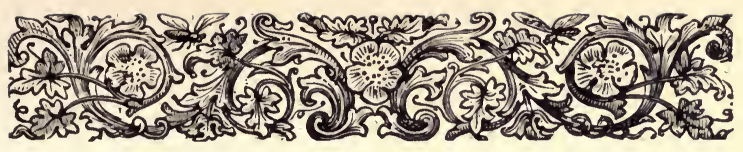

No. I I.-Family CAPRIFOLIÀCE $Æ . \quad$ Honeysuckle Fam.)

Flowers, tubular, narrow bell-form, or funnel-form. Petals, five, united. Stamens, inserted on the corolla and as many as its lobes, - or in Linnæa (I) one less than the lobes. Styles, one. Stigmas, three to five. Seed-case, two- or three-celled, adherent to the calyx.

Leaves, simple, opposite, entire-or sometimes in Linnæa (1) very slightly lobed, or wavy-without real stipules.

Fruit, one- to several-seeded. A berry or a capsule.

GUIDE TO THE GENERA.

Herbaceous, Stamens 4. (I) Linnæa (Twin-Flower).

Woody, Stamens 5. (2) Lonicèra (Honeysuckles).

\section{(1) Genus Linnł̀a, Gr.}

Named for Linnæus, who especially loved the delicate Linnica borealis that is described below.

Fig. 44.-Twin-Flower. L. boreàlis, $L$.

Flowers, nodding, very fragrant, in pairs on long stems from the axils of the leaves. Corolla, rose-color to whitish, narrow bell-shape, five-lobed, soft-hairy at the throat. Calyx, five-toothed. Stamens, four, in two pairs of different length. Seed-case, adherent to the calyx, three-celled (two of the cells abortive). 
Cluster-stems, about three inches in length, erect, slightly hairy. June.

Leaves, small, simple, opposite, rounded, with scattered hairs, sometimes with very slightly lobed or wavy edge.

Fruit, dry. Cells, three (two of them abortive), ripening but one seed. A capsule.

Found, in damp woods and bogs from the mountains of Maryland far westward, and northward to the Arctic Ocean.

A delicate trailing plant, evergreen, herbaceous, with slender stems that branch and root until they carpet the ground.

I was a boy on a tramp among the mountains of New Hampshire, when I first found these pretty and fragrant little bells among wide reaches of damp moss. I did not know then of Linnæus' liking for the flower, and I knew little of botany, but I ranked it then and have ranked it ever since as among the daintiest of all the flowers that grow.

There is said to be a portrait of Linnæus in which the button-hole of the coat is ornamented with this flower.

\section{(2) Genus Lonick̀ra, L. (Honeysuckle).}

From the name of a German botanist of the sixteenth century.

Flowers, tubular, or funnel-form, in stemless clusters in the axils of the upper leaves. Corolla, five-cleft, often swollen at the base. Calyx, small, and very short five-toothed. Stamens, five. Seed-case, two- or threecelled, few-seeded, adherent to the calyx. 


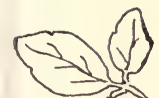

(

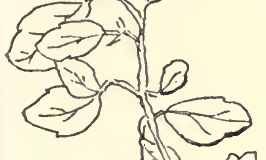

(i) 15

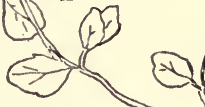

(a)

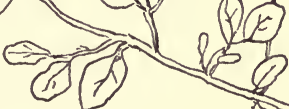

Fig. 44.-Twin-Flower. (L. boreàlis, L.) 
Leaves, simple, opposite, entire.

Fruit, red or orange, several-seeded, marked with the persistent teeth of the calyx. A berry.

Woody vines.

Fig. 45.-Trumpet Honeysuckle. L. sempervirens, Ait.

Flowers, trumpet-shape, nearly regular, without fragrance, about two inches long. Corolla, deep red without, or rarely yellowish, yellowish within; bulging on one side. Stamens and style only slightly exserted. May to July.

Leaves, variable, ovate to oblong or lance-shape, smooth, the upper united by their bases, the lower with stems; in the South persistent and evergreen, but falling in the North.

Found, very common in cultivation, and wild from Connecticut to Indiana and southward.

A showy and vigorous twining shrub, sometimes in rich soil climbing to the top of forest trees. Very ornamental in cultivation.

Blossom resembling Fig. 46.-American Woodbine. Evergreen Honeysuckle. Yellow Honeysuckle. L. gràta, Ait.

Flowers, very fragrant, spreading at the mouth ; the lower lip narrow, the upper lip broad and four-toothed, in clusters of five or six blossoms. Corolla, about one and a half inches long; the slender tube reddish or purplish, the rest whitish, all changing to yellowish ; smooth within, not swollen and not hairy at the base. Stamens and style smooth and much exserted. May, June. 


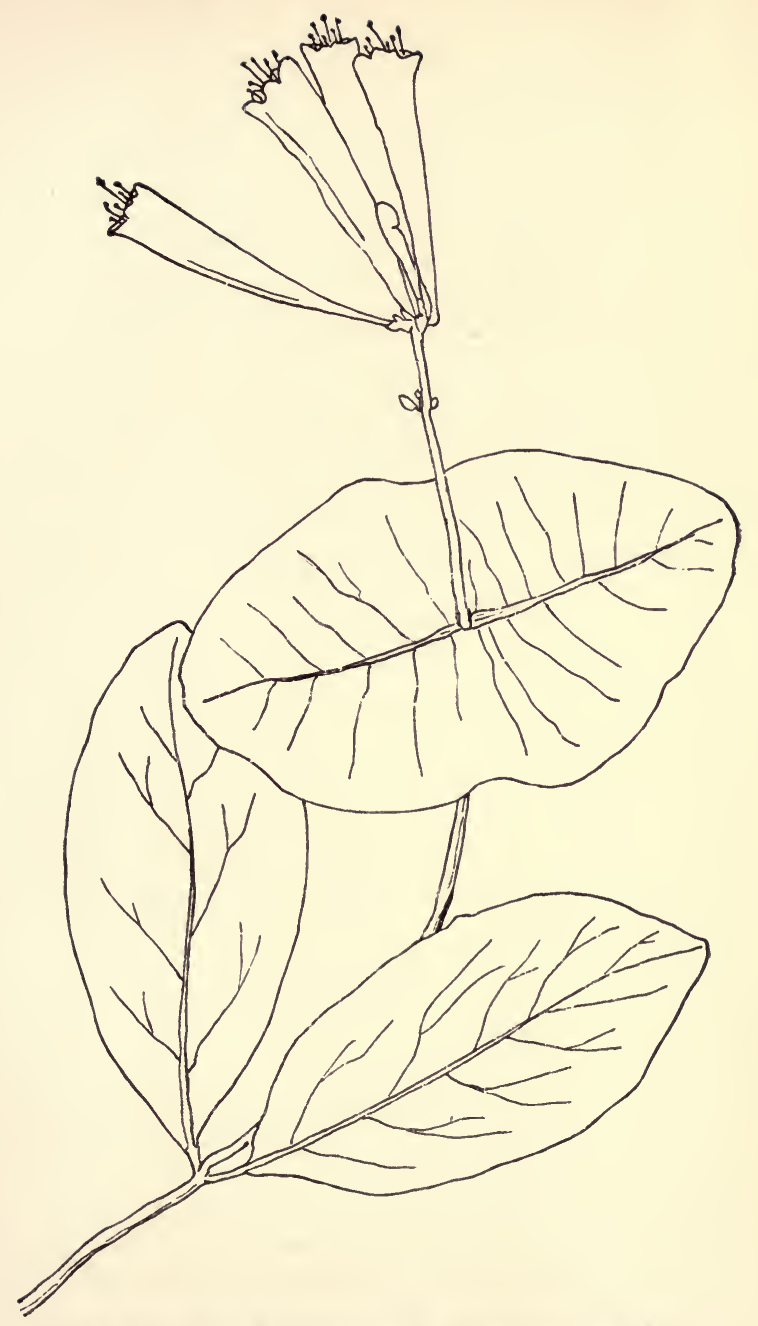

9I Fig. 45.-Trumpet Honeysuckle. (L. sempervirens, Ait.) 
Leaves, evergreen, opposite, sometimes in threes, smooth, usually reverse egg-shape, the upper ones united by their bases. Young branches, often hairy.

Found, in cultivation, and wild, from New Jersey westward, and southward to the mountains of Carolina.

A vigorous, shrubby twiner, ten to twenty feet long. Cultivated for its fragrant flowers and its foliage.

Fig. 46.-Japanese Honeysuckle. [L. Fapónica, T.]

Flowers, about one and a half inches long, in pairs in the axils of the leaves, fragrant, spreading at the mouth, the lower lip narrow, the upper lip broad and toothed, white, changing to yellowish. Tube of coroila, somewhat hairy within and without.

Leaves, one to two and a half inches long, oval to eggshape, opposite, never united. Young branches, hairy.

Found, common in cultivation, and sometimes escaped.

A vigorous, shrubby vine, widely cultivated for its fragrant flowers and its foliage.

Leaf resembling Fig. 45.-Hairy Honeysuckle. L. hirsùta, Eaton.

Flowers, orange-yellow, sticky ; tube, slender, one half inch or less in length, swollen at the base, hairy within. Mouth, lips, stamens, and style as in the last, but the filaments bearded.

Leaves, egg-shape to broad-oval, usually hairy above and on the edges ; downy-hairy beneath ; the upper ones united by their bases, the rest with short stems; veins prominent. Branches, downy-hairy. 


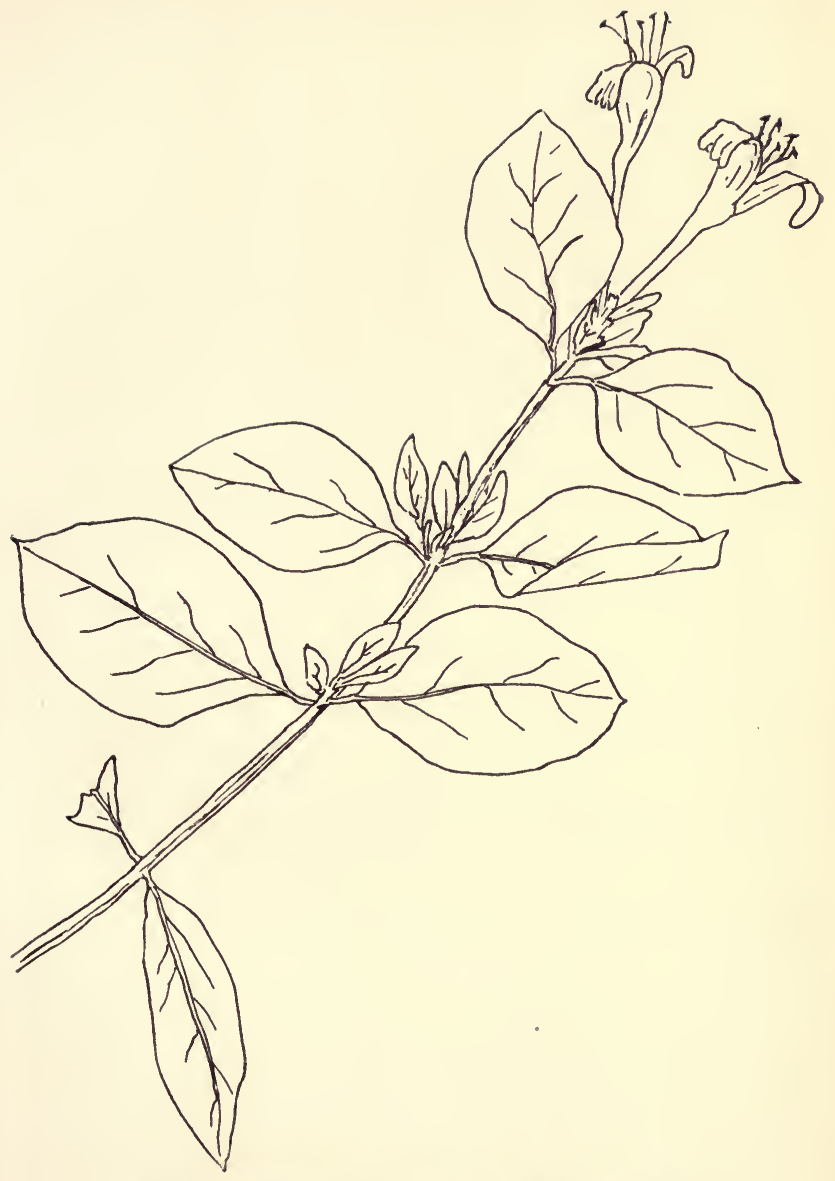

Fig. 46.-Japanese Honeysuckle. [L. Japónica, T.] 
Found, in damp ground from Pennsylvania northward and westward.

A somewhat coarse and large-leaved vine, twining often to the height of fifteen or twenty feet.

Leaf resembling Fig. 45.-Yellow Honeysuckle. L. Sullivántii, G.

Flowers, fragrant, light yellow, usually in clusters of about ten blossoms; tube, about one half inch long, not swollen at base, hairy within; the mouth, lips, stamens, and style, as in the last, but the filaments nearly smooth. May to July.

Leaves, two to four inches in length, smooth, oval to reverse egg-shape, becoming much whitened; stemless, and on the flowering branchlets oftenest united at their bases in pairs.

Found, from New York to Georgia and westward.

A smooth woody vine, scarcely twining, three to six feet in height.

Fig. 47.-Small-Leaved Honeysuckle. L. glaìca, Hill. (L. parvifolia, Lam., and part of var. Douglásii, G.)

Flowers, in clusters usually of crowded blossoms ; greenishyellow or tinged with red. Tube, one third inch in length, hairy within. Mouth, lips, stamens, and style, as in the Woodbine (L. gràta), but the style and the base of the filaments hairy.

Leaves, two to three inches in length or more, oblong, the upper ones united at the base in pairs, the others either united or separate and stemless.

Found, from Pennsylvania westward and northward.

A smooth twining vine three to five feet high. 


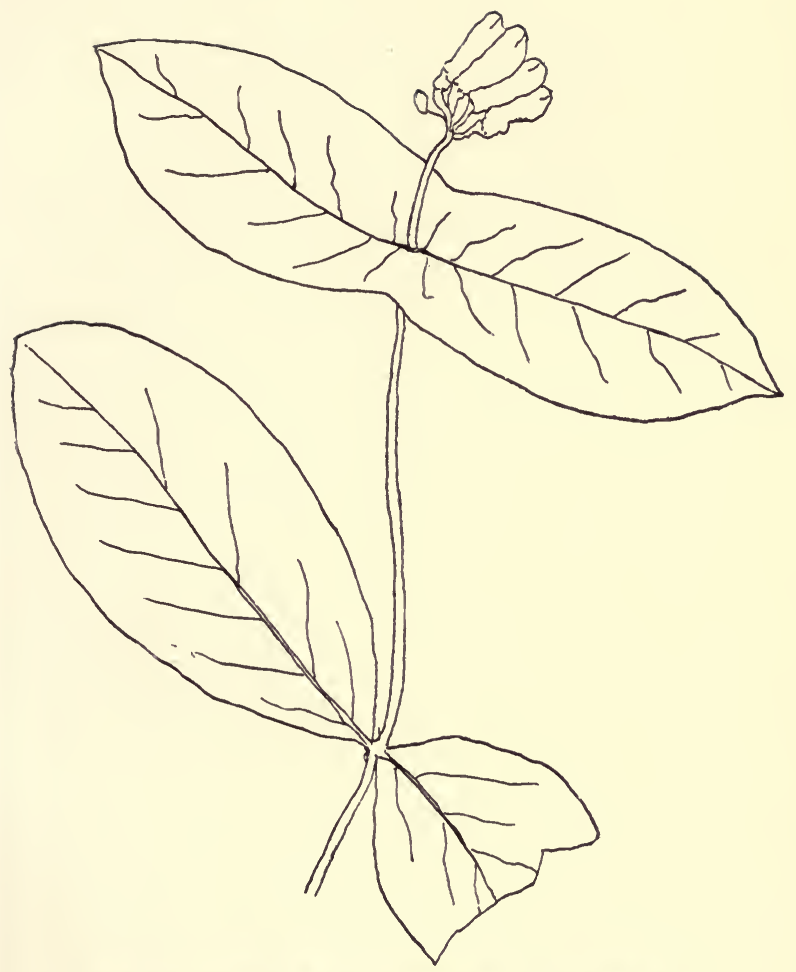

95 Fig. 47.-Small-Leaved Honeysuckle. (L. glaùca, Hill.) 
No. I 2.-Family RUBIÀCEÆ. (Madder Fam.)

GUIDE TO THE GENERA.

Vine, prostrate; stems, cylindrical. (Partridge-Berry).

Vine, ascending; stems, square. (2) Gàlium (Bedstraw).

(I) Mitchélla, L.

(I) Genus Mitchélla, L.

Named for John Mitchell, an early botanist of Virginia.

Fig. 48.-Partridge-Berry. M. rèpens, $L$.

Flowers, about one half inch long, terminal in pairs; white, often purple-tinged, very fragrant. Corolla, funnel-form, four-lobed, densely hairy within. Calyx, four-toothed. Stamens, four, inserted on the tube of the corolla and alternate with its lobes. Style, one. Stigmas, four, line-like. In some specimens the stamens are exserted and the stigmas included, in others the stamens are included and the stigmas exserted. Seed-case, one for the pair of flowers, adherent to the calyx, four-celled; one young seed in each cell. June, July.

Leaves, evergreen, simple, opposite, entire, connected around the stem by minute stipules, one half to five sixths of an inch in length; round egg-shape, slightly heart-shaped at the base, with short stems, smooth and shining, and often marked with whitish lines, turning black in drying.

Fruit, a bright red, edible berry, curious for its double structure-one berry for the pair of flowers, crowned with two sets of calyx-teeth, and with eight small seeds. A berry-like double drupe. 


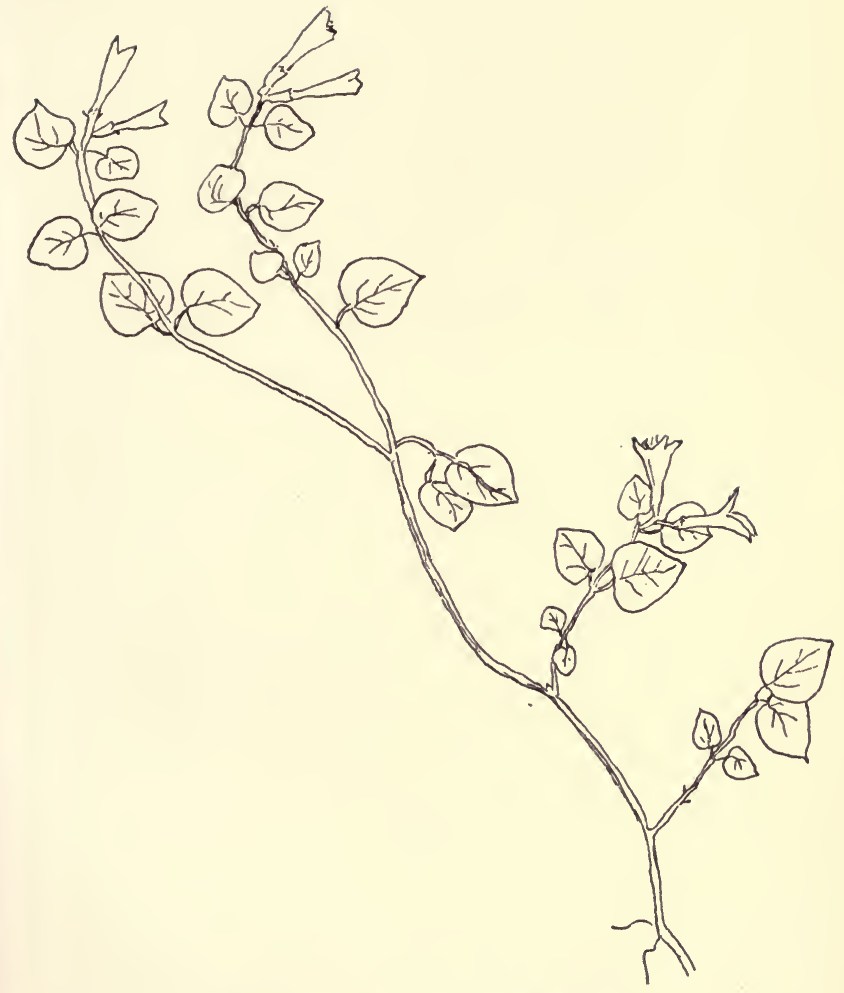

Fig. 48.-Partridge-Berry. (M. rèpens, L.) 
Found, northward and southward, in dry woods, especially about the trunks of pines.

A pretty trailing and woody little evergreen, one to two feet in length, retaining its berries and its leaves throughout the winter. In color and size the red berries resemble the Checkerberry, for which they are sometimes mistaken-needlessly mistaken, however, for their double "eyes" and their lack of spicy flavor easily distinguish them.

\section{(2) Gàlium, L. (Bedstraw).}

From a Greek word meaning " milk" because the flowers of one species, G. vèrum, were used for curdling milk.

Flowers, very small, in clusters; the cluster-stems form the axils of the leaves. Corolla, four-parted, wheelshape. Calyx, minutely four-toothed or entire. Stamens, four, short, inserted on the tube of the corolla, and alternate with its lobes. Style, two, united at the base. Seed-case, adherent to the calyx.

Leaves, simple, opposite, or in whorls around the slender stems ; entire, without stipules.

Fruit, dry, round, double, separating when ripe into two one-seeded parts. Achenes or nutlets.

Weak climbing and leaning herbs, with square stems that in most species are very rough on the edges.

Fig. 49.-Bedstraw. Goose-Grass. Cleavers. G. Aparine, L.

Flowers, white, numerous. Cluster-stems, branching, each branch bearing one or two (sometimes three) blossoms. June. 

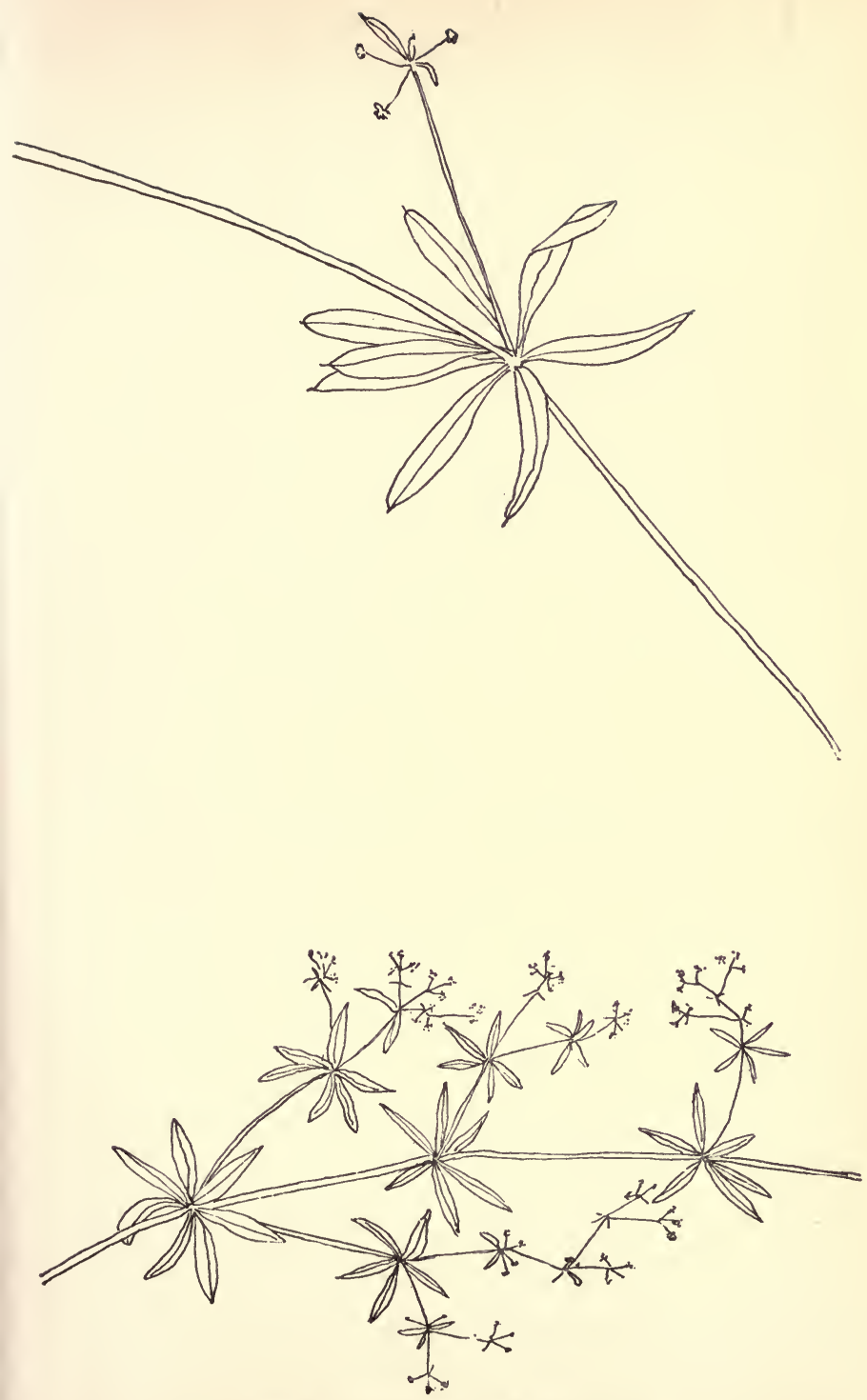

Fig. 49.-Bedstraw. (G. Aparìne, L.)

99 Fig. 50.-Rough Bedstraw. (G. aspréllum, Mx.) 
Leaves, one to two inches in length, very narrow, about eight in a whorl (sometimes only six), lance-shape or reverse lance-shape, rough on the mid-veins and the edges.

Fruit, covered with very fine hooked prickles, which when ripe cling at a touch, so aiding in the distribution of the seed.

Found, in shaded ground from Indiana through the Northern States to Canada.

A weak vine several feet in length ; its stems reclining, hairy at the joints, square, and rough with downwardpointing bristle-prickles, by help of which the vine climbs. The root yields a red dye, and the leaves are used medicinally.

"As girls we used to rub from the fruit the prickles, and then play the white seeds within were pearls. The lustre was indeed very pearl-like, but it would not last."

Fig. 50.-Rough Bedstraw. Rough Cleavers. G. asprellum, $M x$.

Flowers, white, numerous. Cluster-stems, two or three times forked.

Leaves, five twelfths to two thirds inch in length, four to six in a whorl (usually six on the main stems, and four or five on the branches), one-veined, the margins and the mid-vein roughened with prickles, lanceshape to oval, sharp-pointed.

Fruit, minute, smooth, or often when young slightly hairy. 
No. 12]

Found, common in thickets and low ground in the Northern States and Canada.

A weak vine two to five feet in length, much branching. Its stems are reclining, square, and rough with minute downward-pointing and hooked prickles by help of which the vine clings and climbs.

Resembling Fig. 50.-Small Bedstraw. G. trifidum, $L$.

Flowers, very small, white, on one- to seven-flowered stems. Petals and stamens, often only three.

Leaves, unequal, in whorls of four to six or seven, linelike to reverse lance-shape, not sharp-pointed, three twelfths to seven twelfths inch long, one-veined; edge and mid-vein, rough.

Fruit, smooth.

Found, in boggy and wet ground throughout the continent.

A weak, ascending vine, one to two feet long, branching and interlacing, with the stems usually roughened backwards on the edges. Dries black.

Fig. 5I.-Sweet-Scented Bedstraw. G. triftòrum, $M x$.

Flowers, greenish-white. Cluster-stems, mostly threeblossemed.

Leaves, one to two inches in length, four to six in a whorl, one-veined, the margins slightly roughened, lance-shape to oval or to reverse egg-shape ; bristlepointed. 
Fruit, covered and whitened, with hooked bristles.

Found, in rich, damp ground throughout the United States and Canada.

A weak vine, one to three feet in length, with the angles of the stem roughened backwards. The plant is fragrant in drying.

\section{Fig. 52.-Hairy Bedstraw. G.pildsum, Ait.}

Flowers, purplish. Flower-stems, two- or three-forked. July to Sept.

Leaves, one inch long (or sometimes less), four in a whorl, oval, not bristle-pointed, three-nerved ; surface somewhat hairy and dotted.

Fruit, beset with hooked hairs.

Found, from Vermont to Illinois and southward.

A weak perennial vine, one to three feet long, reclining or sometimes erect. Stems branching, hairy on the edges or somewhat rough.

No. I3.-Family COMPÓSIT Æ. (Composite Fam.)

Genus Mikània, Willd.

Named after a botanist of Prague.

Fig. 53.-Climbing Hemp-Weed. Climbing Boneset. $M$. scándens, $L$.

Flowers, flesh-colored to pale purplish, in clusters made up of many small heads, each head composed of four 
blossoms and surrounded by four narrow scales. Corolla, tubular. Calyx represented by a row of slender roughened bristles. Stamens, five, inserted on the corolla. Anthers, united in a tube around the style. Style, one, two-cleft at the apex. Seed-case, onecelled, one-seeded, united to the calyx. July to Sept.

Leaves, mostly two to three inches in length, simple, opposite, toothed, or sometimes entire, pointed at the apex, with the base usually heart-shaped, and often unequally lobed. Leaf-stem, mostly one to two inches long.

Fruit, seed-like, dry, five-angled, lengthwise. An achene.

Found, along the borders of streams and in damp thickets from New England southward. Somewhat rare.

A beautiful vine more or less herbaceous with long twining stems, smooth or nearly so throughout.

Nearly every Sabbath the summer through, the simple village church where we worshipped was made beautiful with wild flowers. Especially was it so one Sabbath in September. The Saturday before, Miss Mary and the younger children had taken Toby (their small black pony, æt. 25 years or thereabout) and driven a mile down the shore. There in a swampy stretch at the side of the road they found in abundance the beautiful climbing hempweed. It screened to their tops and over their tops the high bordering thickets. They gathered their prize in masses; and the next day its grace and its beauty preached with the preacher to the worshippers in God's house. 


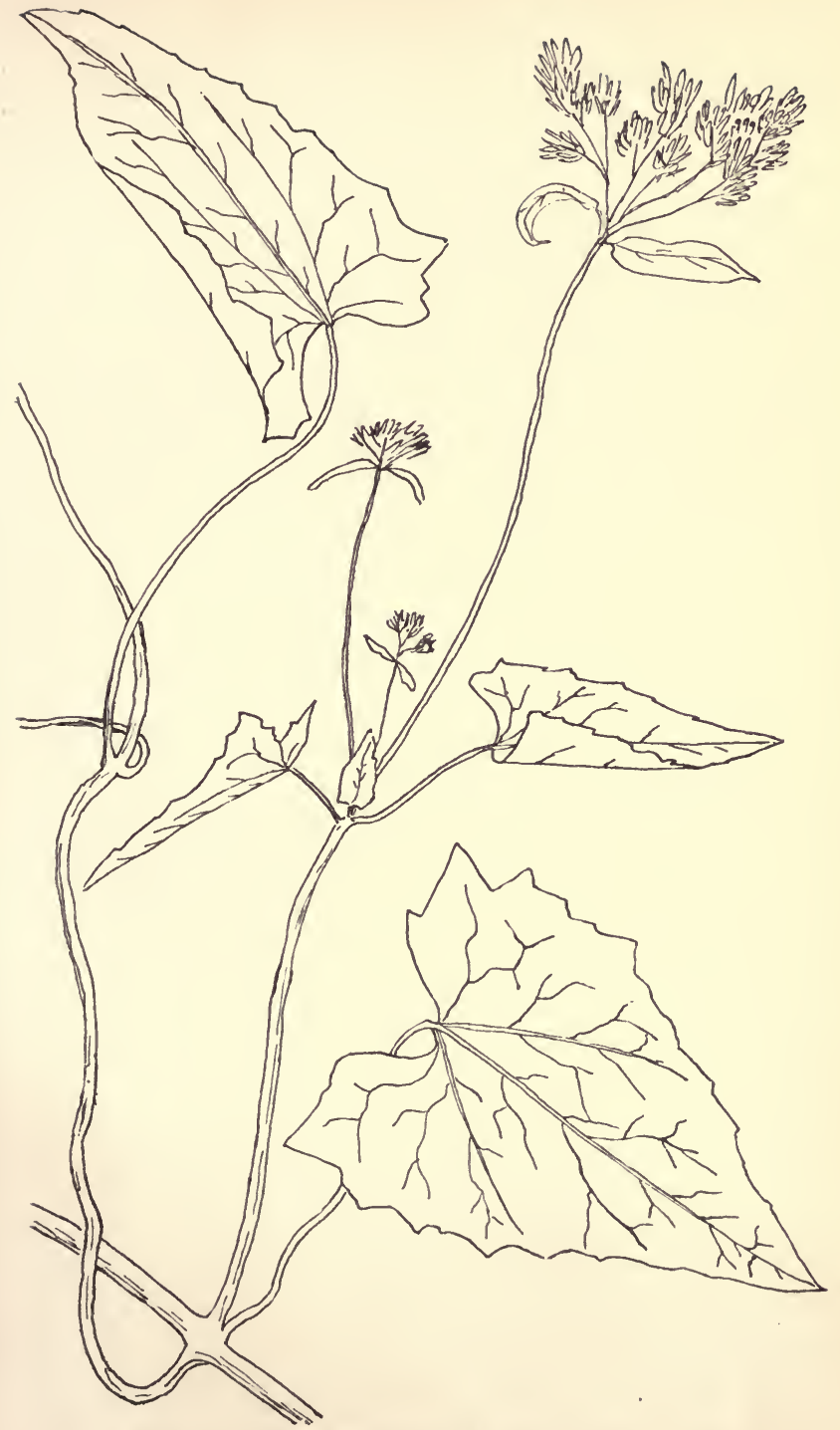

I05 Fig. 53.-Climbing Hemp-Weed. (M. scándens, Willd.) 
No. 14.-Family ERICÀCEÆ. (Heath Fam.)

Flowers, regular. Petals, four or five, united. Stamens, twice as many as the petals, and inserted with them. Pollen, of four united grains. Style, one. Seed-case, four- or five-celled, and many-seeded except in Bearberry (Arctostáphylos, No. 3).

Leaves, simple, alternate, entire, without stipules.

Fruit, a berry, or, in Arbutus (No. 4), a capsule.

Prostrate vines.

GUIDE TO THE GENERA.

(a) Leaves half inch in length, or less.

(b) Leaves whitened beneath. Berries red. (1) Vaccínium (Cranberry).

(b) Leaves rusty-bristly beneath. Berries white. Chiógenes (Snowberry).

(a) Leaves about one inch in length, or more.

(b) Leaves reverse egg-shape or spatulate. Edge entire. Berry red. (3) Arctostáphylos (Bearberry).

(b) Leaves heart-shape. Fruit a capsule. (4) Epigæ̀a (Arbutus).

(b) Leaves reverse egg-shape or oval. Edge toothed. Berry red. (5) Gaulthèria (Wintergreen).

(i) Genus Vaccínium, L.

Fig. 54.-Large Cranberry. American Cranberry. $V$. macrocárpon, Ait.

Flowers, pinkish, nodding on the ends of slender erect stalks. Petals, four, very narrow, rolled back, united below. Calyx, four-cleft. Stamens, eight. Anthers, lengthened upward into slender tubes, exserted, nearly 

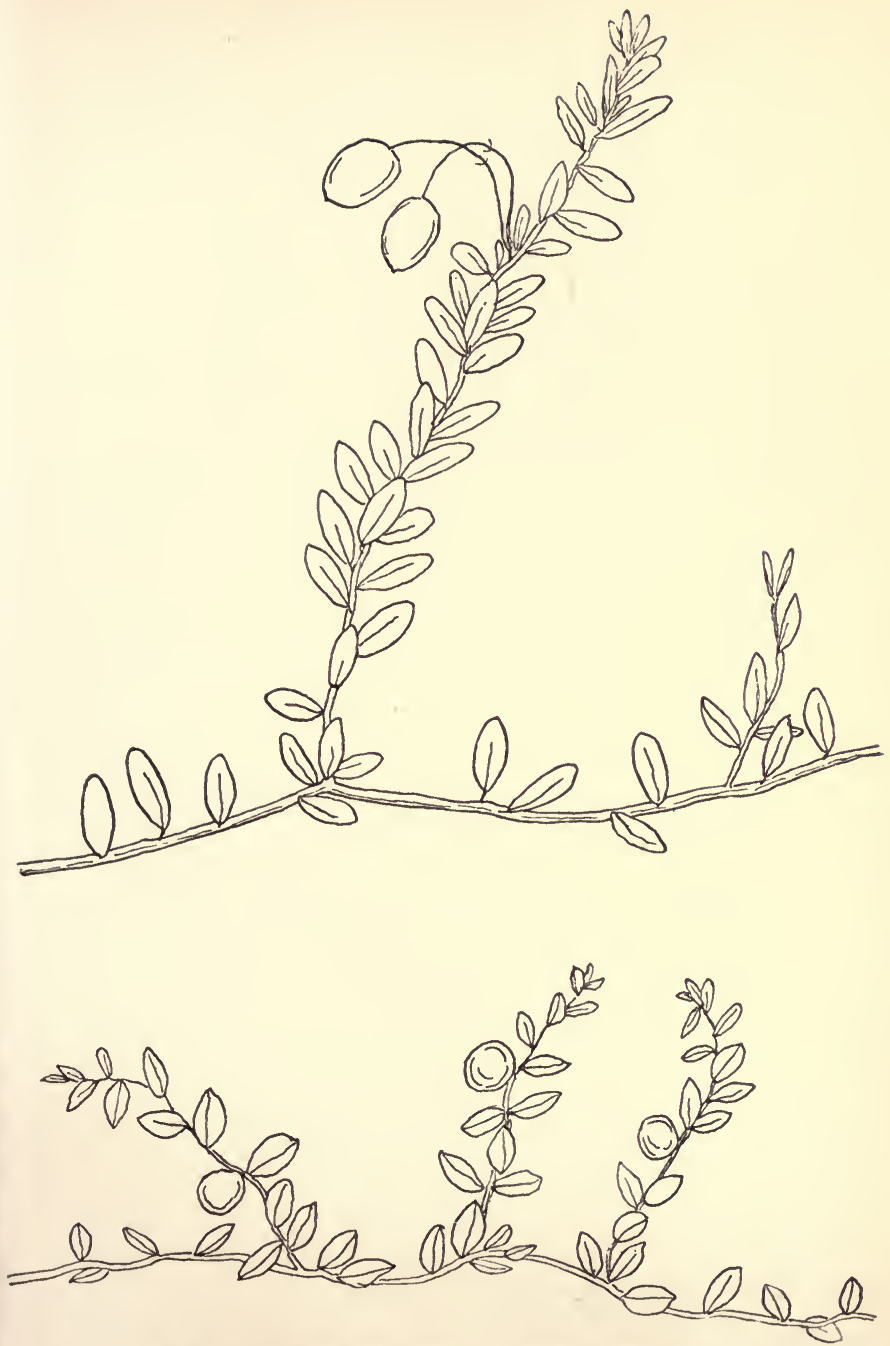

Fig. 54.-Large Cranberry. (V. macrocárpon, Ait.)

107 Fig. 55.-Creeping Snowberry. (C. serpyllifollia, Salisb.) 
three times as long as the filaments. Flower-stems, one to several, from the base of the new shoots, one half to one and one quarter inches in length, with two small bracts near the middle. Seed-case, four-celled; many-seeded, adherent to the calyx. June.

Leaves, evergreen, one third to one half inch in length, simple, alternate; edges entire, smooth, whitened beneath, oval to oblong with rounded base, and rounded or slightly pointed apex.

Fruit, one half to one inch in length, rounded or slightly lengthened, edible when cooked, red of varying shades, very acid, many-seeded. A berry.

Found, in peaty and swampy ground from North Carolina northward to the Arctic Ocean, often in great abundance.

A very pretty trailing and woody evergreen, one to four feet in length.

The Cranberry has come to be of very great value as a market fruit. Swampy land, that once was deemed worthless, is now made to yield large and valuable crops. In some regions, along the New Jersey coast for example, the time for the harvesting of the cranberry crop is as busy and important a time as that of the wheat harvest elsewhere. The country around is scoured for pickers. Then early and late the flat, drained, or sun-dried grounds are picturesque with the busy workers.

“'The name, 'Cranberry,' may be due to the reputed liking of the Crane for the berry, or to the crane-like neck beneath the nodding berry." 
The little plant is very tough, notwithstanding its delicate proportions, of ten flourishing where few other things could live.

\section{"' $\mathrm{T}$ is such a wee, fair, dainty thing, You'd think a greenhouse warm. Would be its proper dwelling-place, Kept close from wind and storm. \\ "But on the moor it dwelleth free, \\ Like a fearless mountain child, With a rosy cheek, a lightsome look, And a spirit strong and wild."}

LOUiSe TWamLy.

Resembling Fig. 54.-Small Cranberry. V. Oxycóccus, L.

This species differs from the preceding chiefly in these items :

Flowers, with the anthers not more than one half as long as the filaments.

Leaves, one sixth to one quarter inch in length, eggshape. Edge, strongly rolled under. Apsx, pointed.

Fruit, one quarter to one third inch in length, often whitespeckled when young, seldom marketed.

Found, from Pennsylvania and New England far northward.

" $V$. oxycóccus, L., is found wild in England, Ireland, Central and Northern Europe, on the wilds of Siberia 


\section{(2) Genus Chiógenes, Salisb.}

From two Greek words meaning " snow" and " offspring," with reference to its snowwhite berries.

Fig. 55.-Creeping Snowberry. C. serpyllifolia, Salisb. C. hispidula, T. and $G$.

Flowers, white, bell-shape, very small, solitary, on short nodding stems from the axils of the leaves, and with two bractlets under the calyx. Corolla, deeply fourcleft. Calyx, four-parted, persistent. Stamens, eight, not exserted. Filaments, short and broad. Seed-case, four-celled, many-seeded, adherent to the calyx. May.

Leaves, evergreen, one quarter to one third inch in length, alternate, egg-shape or oval, pointed ; margins rolled under; upper surface smooth, under surface set sparingly with stiff, rusty hairs. Branches, slender and like the leaves beset with rusty hairs.

Fruit, one quarter inch in diameter, rounded, bright white, four-celled, many-seeded, edible. A berry.

Found, in swamps and mossy woods from North Carolina through the Alleghany Mountains, and far northward and westward.

A slender woody creeper, evergreen, from one to two feet in length; its berries and foliage pleasantly flavored, with the aroma of wintergreen.

I pulled my row-boat, one August day, to the shore of an island in Lake Placid, and left it there safe among the rocks. Walking a few yards inland, I found myself suddenly in a new world. Instead of water and open 


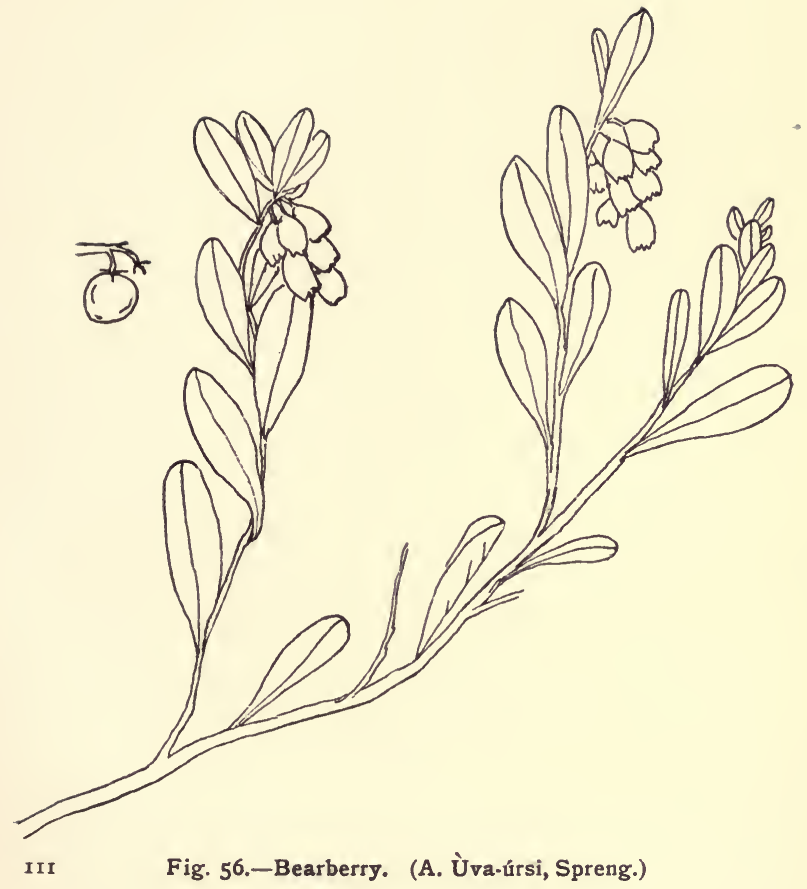


skies, I was shut in overhead by the tops of ancient trees, and on the level by a curtaining screen of thick shrubbery, and beneath by a carpet that was woven and figured with fallen branches and rocks and leaves and deep, velvet-soft moss. As I looked more closely I saw that this moss was threaded everywhere with the delicate, creeping snowberry, in fruit.

(3) Genus Arctostáphylos, Adans.

From two Greek words meaning " bear" and " grapes."

Fig. 56.-Bearberry. Dogberry. A. Ùva-irsi, Spreng.

Flowers, somewhat resembling those of the related Trailing Arbutus, whitish, in short, terminal, drooping clusters. Corolla, egg- or urn-shape, five-toothed, the teeth turned back, hairy within. Calyx, reddish, five-parted, persistent. Stamens, ten, not exserted. Anthers, each with two hairs on the back near the apex. Filaments, hairy. Seed-case, free. May.

Leaves, evergreen, about one inch in length (sometimes shorter), simple, alternate, smooth, entire, reverse egg-shape or spatulate, thick and rigid, with short stems.

Fruit, round, about the size of a currant, red, rather insipid. Nutlets, five, firmly united. A berry-like drupe.

Found, in the most barren places-on gravelly hills and in dry woods-from New Jersey (where it is very common in the sandy pine-barrens), and Pennsylvania to Missouri, and far northward, often covering the ground in broad patches. 
A trailing evergreen shrub, two to three feet long, with the younger branchlets erect and from three to eight inches in height. It is useful for tanning the finer kinds of leather. The leaves are astringent, and used medicinally. At one time they were recommended as a remedy in consumption. It is the kinnikinnic of the Indians, who smoke it, and believe it to be a safeguard from malarial fever.

The little vine is found in far northern regions wellnigh the world around-in Sweden, Lapland, Iceland, Siberia. It is nearly related to the trailing Arbutus, with which it was once grouped generically. To the older botanists it was known as Arbutus Uva-ursi.

It is unusual for the generic Greek name and the Latin specific name, and the common English name, all, as in this case, to mean the same.

The fondness of birds and other animals for its berries doubtless accounts in part for its wide distribution. To human taste the flavor is not agreeable.

\section{(4) Genus Epigìa, L.}

From two Greek words meaning " upon " and "ground," with reference to the trailing growth.

Fig. 57.-Trailing Arbutus. Ground Laurel. Mayflower. E. rèpens, $L$.

Flowers, in compact clusters from scaly bracts in the axils of the leaves, with very pleasant spicy odor. Corolla, oftenest delicately pink-tinged, varying from white to deep rose ; five-lobed, the lobes rounded and spreading, the tube hairy within. Calyx, of five-pointed, scale-like, nearly distinct sepals; about the length of the corolla-tube, and with three bracts at its base. Stamens, ten, with slender filaments. Style, one. Stigma, slightly five-lobed. Seed-case, five-celled, many-seeded, free. April and May. 
Leaves, evergreen, two to two and one half inches in length, simple, alternate, entire, from rounded to eggshaped. Apex, rounded or with a slight point. Base, heart-shaped; the older leaves coarse and rough, in strong contrast to the delicate blossoms. Leaf-stem, hairy.

Fruit, rounded, five-celled, many-seeded. A capsule.

Found, oftenest in sandy woods, from Newfoundland westward, and southward to Pennsylvania and Kentucky, or, less frequently, to Florida.

A trailing woody evergreen, ten to fifteen inches in length, rough, with bristly, reddish hairs. It is coarse in aspect, the old worn and broken leaves clinging long after the appearing of the blossoms and the new leaves. Oftenest the whole is hidden away, and sometime wholly covered from sight by the winter's drift of dead leaves.

In New England the Mayflower, as it is there called, is among the earliest of the spring flowers, and is the best loved of them all. In some localities it figures prominently in the May-day festival. The children search, and bring it in quantities from the woods. Then at dusk they take little baskets, sometimes made of paper for the occasion, neatly trimmed with moss and heaped with the fragrant blossoms, and carrying them to the homes of their special friends, hang them on the door knobs, knock and run. At least, years ago the New England children did so. I hope they do so yet. 


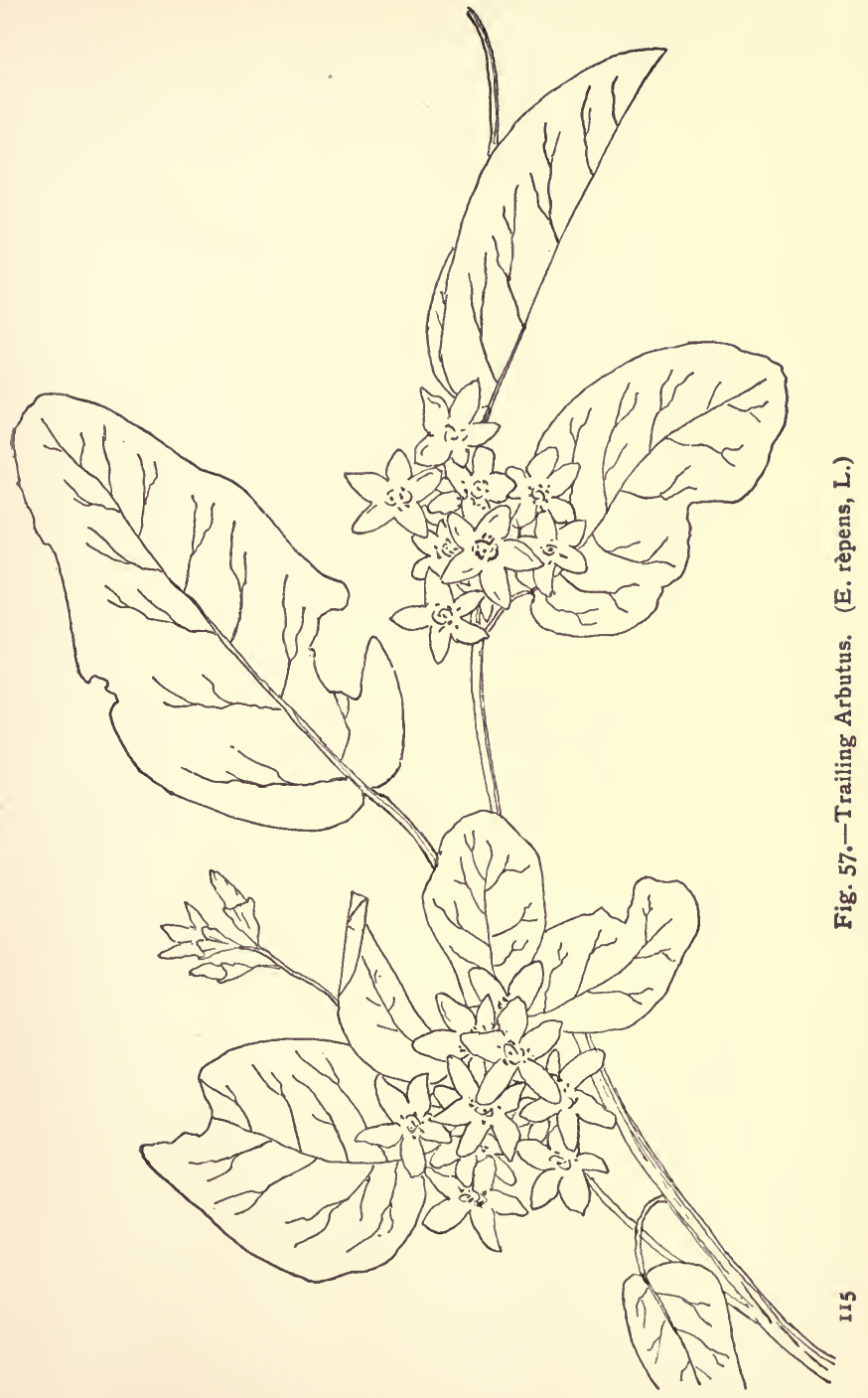




\section{A Legend of the Trailing Arbutus.}

A sweet old legend drifts and ever drifts, In lines and rhymes, amid these breaths of spring. I hear it in the voice of tinkling brooks Set free but now from winter's gorgon spell; I hear it in a herald bluebird's notes, And where a bee goes humming by in search Of early flowers (steer well, small ship ; Sail not too near the reefs of lingering snow); I see it in the yellow aments soft And pendulous from unleaved alder boughs; In softest shadows, too, of deepening green On southward slopes with sheltered nooks between.

Far off in Eden's pleasant bowers,

By grace of God a flower was born, Whose pride of leaf and pride of bloom Could even Eden's bowers adorn.

Its lightly clustered petals seemed

A tinted fragrance when they bloomed;

Its wealth of leaves in texture firm

A look of queenly robes assumed.

The flower was deemed the queen of all The flowers that Eve and Adam kept. With all the flowers it drooped and mourned When Eve and Adam sinned and wept.

They wept at thought of $\sin$ and loss,

They wept at thought of banishment, They turned them to their lovely flowers Ere forth to toil they weeping went.

Then none of all that blooming band

Of lovely Eden flowers did aught

But droop and mourn-till they bethought;

And straightway Him, the Master, sought.

Of Him they humbly prayed that they With Eve and Adam forth might go, 
To soothe perchance the exiles' lot.

The Lord approved, and bade them so.

But oh ! the Lord, He named them first

A hard condition : If they went, They all must yield their wealth of leaves.

At that was sore bewilderment.

Then Eve and Adam turned away,

And wept again for loss begun;

And none of all the lovely flowers

Did aught but mourn anew-save one ;

And that the one deemed there the best,

The queen, the fair Arbutus flower,

Whose springing boughs and wealth of leaves

Were still the pride of Eden's bower.

"Yea, Master, I will go,

I love them so.

For coarser robe and trailing bough

I yield my wealth of leaves.

My spirit grieves,

But now, thou Lord of love,

I pray thee teach me from above

To ever brighten with my bloom

The shadows and the gloom

Of sin-cursed lands,

Where exiles toil with weary hands,

And roam with fading memory of home."

Then Eve and Adam checked their sighs, And blessed that loving Eden flower;

While all the flowers, for love and loss,

Drooped low and long in Eden's bower.

Full oft, in far and sin-cursed lands,

Where soon those exiles learned to roam, A coarse-robed, trailing flower was all

That gave them memory of home. 
" $\Gamma$ is so the quaint old legend seems to-day

To drift and ever drift, with murmurs low

Of bees, and love-songs of the mating birds,

And odors rare, and tinklings bright of rills

That ring their silver bells adown the hills.

But, nay! It is not legend all and all ;

For, as I stoop beside this sheltered nook,

Behold, half-hidden 'neath a drift of leaves,

The Eden flower! Coarse-robed it lies, yet fair

As when it smiled on Eve in paradise.

$O$ fallen queen ! I will not touch thy bloom;

I leave thee here amid these breaths of spring;

For, exiled queen of Eden's pleasant bowers,

I deem thee still the queen of spring-time flowers.

\section{(5) Genus Gaulthèria, Kalm.}

From the name of a French physician of Quebec.

Fig. 58.-Wintergreen. Checkerberry. Boxberry. TeaBerry. Partridge-Berry. G. procuimbens, $L$.

Flower, nodding on slender stems, oftenest solitary. Corolla, cylindrical or urn-shape, five-toothed, the teeth turned back. Calyx, five-cleft, with two bracts at the base, becoming fleshy and berry-like in fruit. Stamens, ten, included, hairy. Anther-cells, each with two slender hairs at the summit. Filaments, white and hairy. Seed-case, five-celled, many-seeded, free from the calyx but finally enclosed by it. Flowerstem, downy, with two small bracts. June to September.

Leaves, evergreen, thick, and shining; when young of a delicate reddish-brown, simple, alternate, often clustered at the top of the upright branchlets; edges very slightly toothed; oval or reverse egg-shape, usually pointed at each end ; very spicy and pleasant to the taste. 


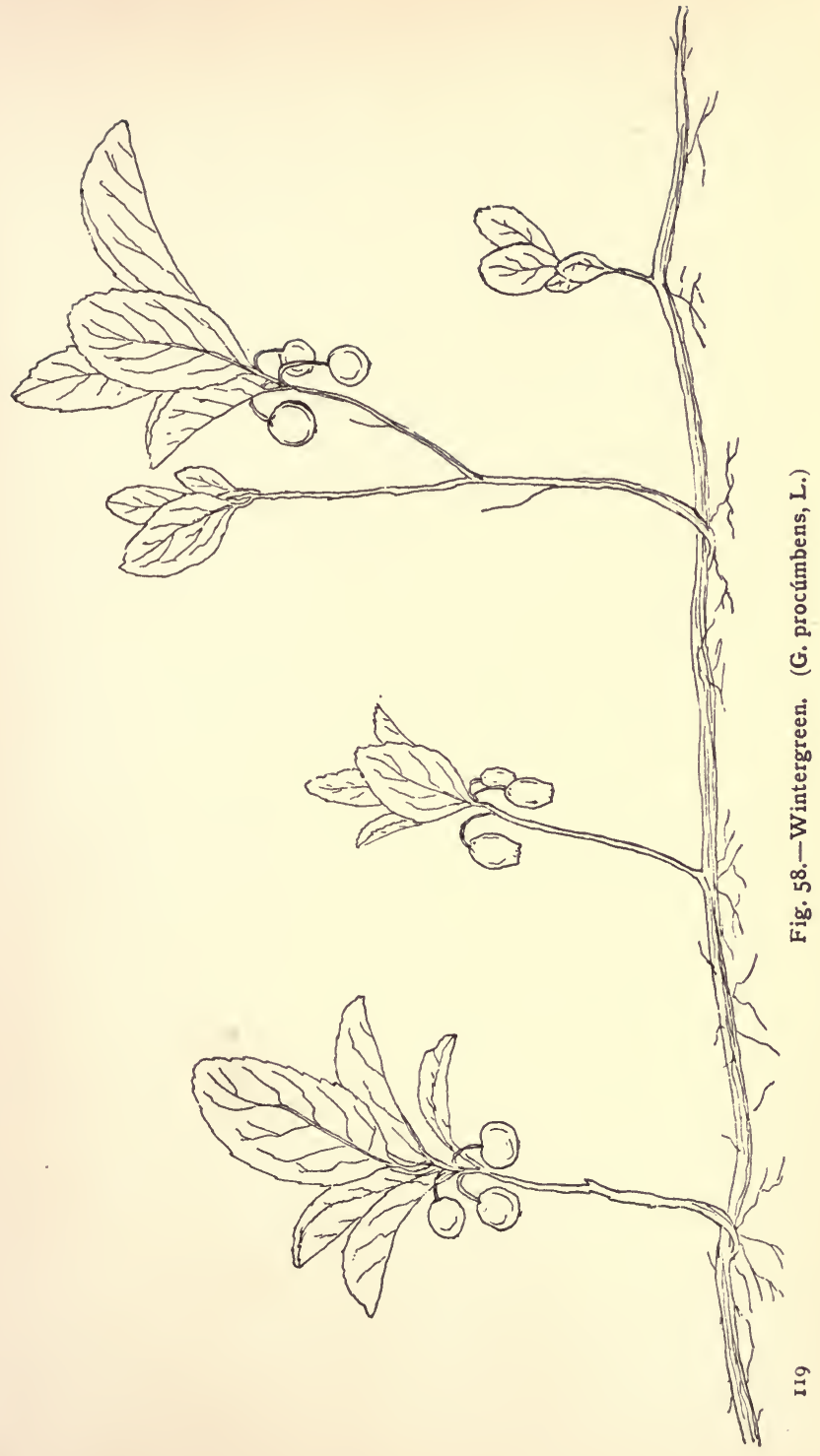


Fruit, red, globular, many-seeded, edible; formed by the thickening of the calyx around the enclosed seed-case. A berry.

Found, oftenest in cool, evergreen woods, from Georgia far northward and sometimes southward to Florida.

A woody evergreen, the stem creeping extensively oftenest a little below the surface of the ground. From the stem spring erect, flowering branches, three to five inches in height. The edible fruit and the young leaves are very spicy, aromatic, and slightly astringent. They are sometimes used to flavor tea, or even as a substitute for tea.

The names that are most common in New England are Wintergreen and Checkerberry; sometimes also it is called Partridge-Berry. Locally, the children give the tender brownish leaves other names - "Jinks," "Pippins," "Drunkards." In New Brunswick and in parts of Maine the name is "Ivory." Among the hills of Southern Ohio, it is "Mountain-Tea." Tea-Berry is a common name westward.

By what alchemy can the little Checkerberry-vine and a tree-the unrelated Black Birch-both elaborate from the elements around them the same most pleasant scent and flavor. One other vine, still more modest, and of less wide distribution, and with fruit as white as the Checkerberry is red-the pretty creeping Snowberry of the North * - shares with them the wonderful secret.

The Wintergreen seems rather to ignore the seasons in its blossoming and its ripening of fruit. Its small red

* Described on page iro. 
balls may be found nearly the year around, and its blossoms from spring to fall. Moreover, it has but slight care concerning location. It rather prefers damp, rich ground, but it thrives also in the sandiest and driest. It can accomplish something more perhaps where sun and sand are not against it; but the pretty little thing seems equally happy everywhere.

\section{No. 1 5.-Family DIAPENSIÀCEÆ. (Pyxie Fam.)}

\section{Genus Pyxidanthèra, Mx.}

From two Greek words meaning "box" and " anther," with reference to the construction of the anthers.

Fig. 59.-Pyxie. Flowering Moss. P. barbulàta, $M x$.

Flowers, one quarter of an inch across, white or sometimes rosy, solitary, stemless, bell-shaped, very abundant, at the ends of short leafy branchlets. Petals, five, rounded, united. Calyx, persistent. Sepals, thin, very finely toothed, with small, prominent bracts beneath. Stamens, five, inserted on the corolla, with the filaments adherent to it. Anther-cells opening across, each with a slender bristle at its base. Style, one. Stigma, three-lobed. Seed-case, three-celled, many-seeded, free from the calyx. April, May.

Leaves, evergreen, one quarter inch in length, or less, simple, crowded, the upper ones alternate, entire, narrow, mostly reverse, lance-shape, pointed, somewhat hairy near the base. No stipules.

Fruit, three-celled, many-seeded, enveloped in the persistent calyx. A capsule.

Found, from the sandy pine-barrens of New Jersey to North Carolina. 
An interesting little woody, evergreen, prostrate vine, three to six inches in length; not widely distributed, but abundant in localities, often covering the ground in flower-dotted mats of interlacing branches.

I do not know why it is, but I have a feeling toward this pretty little plant, much like one's feeling for the Brownies as though they were themselves a sort of Brownie tribe. I suspect the long name has something to do with it-Pyxidanthèra barbulàta-and the blossom, snuggling down as only a Brownie can, among the tiny leaves. Then the abbreviation Pyxie is suggestive of Puck, a first-class Brownie. And the small witches choose most unique places for their homes. I have in mind one such home where I used to visit them-a slope of white sand on the edge of a cranberry bog, with miles and miles of tall pines shutting it away from the outside world-excepting on the lower side where there was a break, with a far glimpse toward the ocean. If only it had been a trifle later and the sun gone down, one might have found himself listening for the Pyxies-or the Brownies-whispering.

No. I6. -Family PRIMULÀCEÆ. (Primrose Fam.)

Genus Lysimáchia, Tourn.

Fig. 60.-Moneywort. Creeping-Charlie. [L. nummulària, $L$.]

Flowers, large (about one inch across), yellow, wheel-shape, solitary, opposite, from the axils. of the leaves. Corolla, deeply five-lobed, the lobes rather blunt and broadly reverse egg-shape. Calyx-lobes, narrower and shorter. Stamens, five, inserted on the base of the corolla, and opposite its lobes. Filaments, slightly 


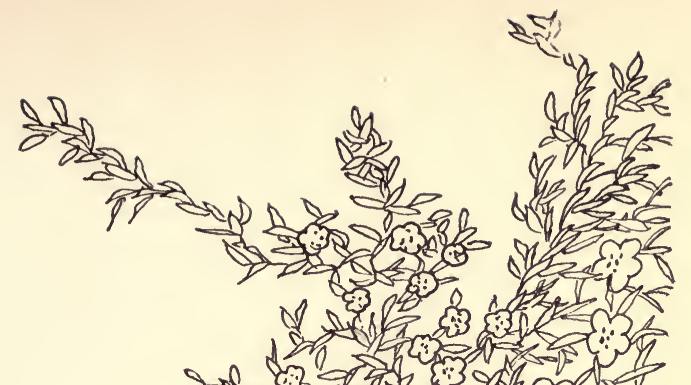

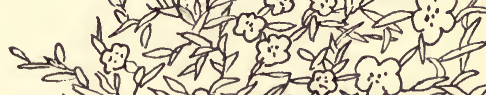
An

sै - 7 -
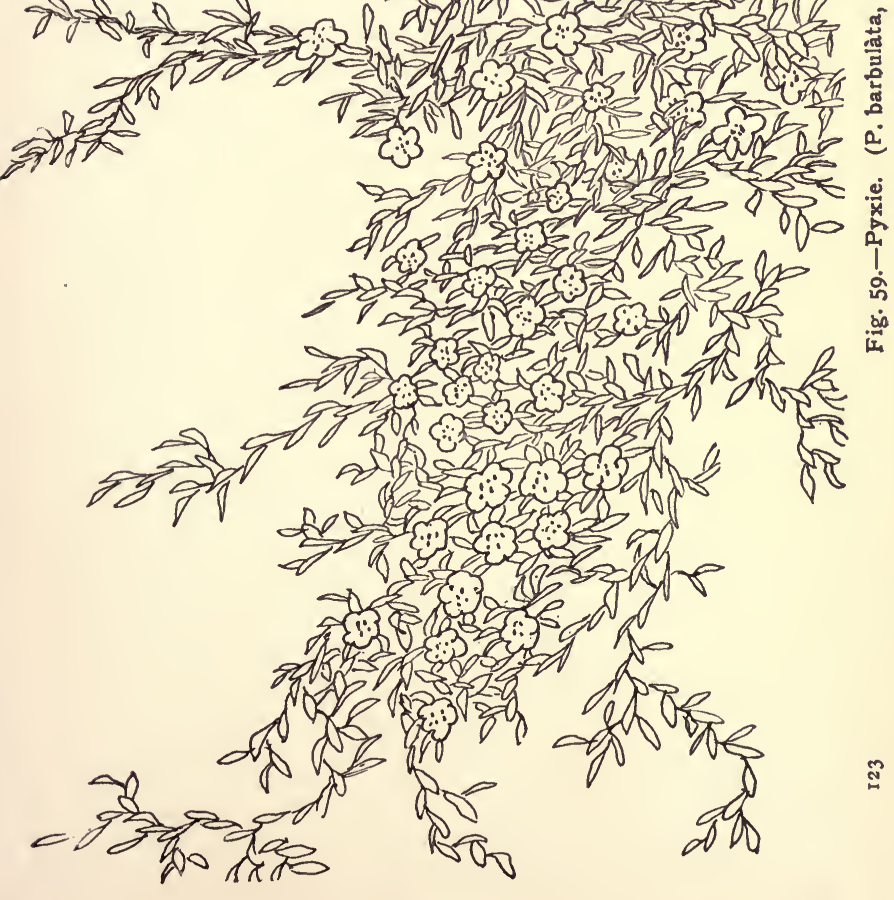
united toward the base. Style, one. Stigma, one. Seed-case, free, one-celled, few-seeded. July, September.

Leaves, simple, opposite, entire, rounded, dotted, smooth, very short-stemed. Base, somewhat heart-shape. Apex, rounded.

Fruit, rounded, one-celled, few-seeded. A capsule.

Found, in damp ground escaped from gardens.

A trailing herbaceous vine very common in cultivation, especially in old gardens. Introduced from Europe.

"It is reported that if serpents be hurted or wounded, they do heal themselves with this herbe, whereupon came the name serpentaria. . . . It is called nummularia, of the form of money, whereunto the leaves are like." -Gerard's Herball.

No. I 7.-Family ASCLEPIADÀCEÆ. (Milkweed Fam.)

Flowers, in axillary clusters. Petals, five, united. Sepals, five, united. Stamens, five, united throughout (except in Períploca Græ̀ca, where the filaments are distinct). Anthers, adhering to and covering the stigma. Styles, two. Seed-cases, two, free from the calyx, covered by the united stamens; many-seeded.

Leaves, simple, opposite, entire, without stipules.

Fruit, one-celled, many-seeded, opening on one edge. A follicle.

Plants with milky juice. 


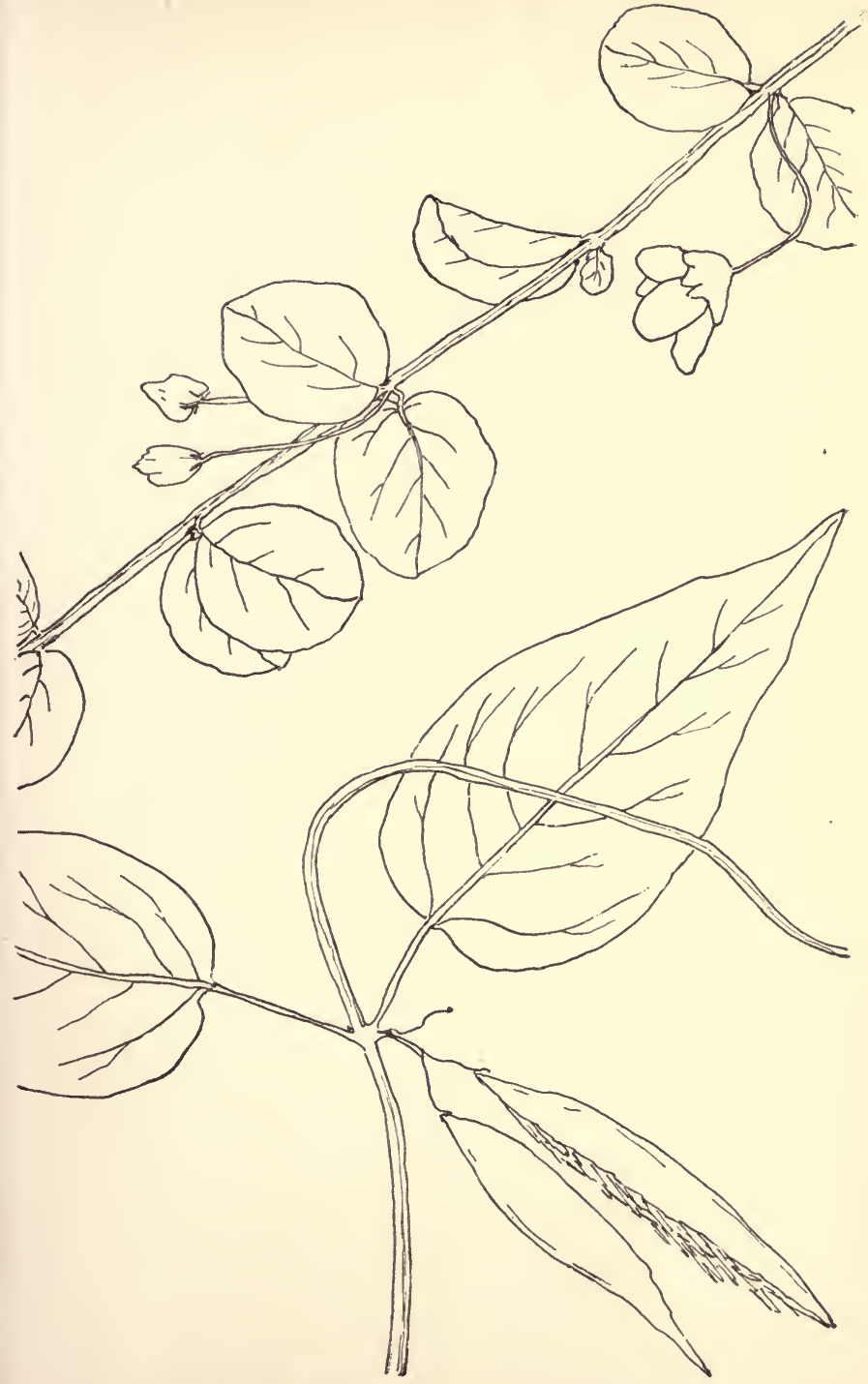

Fig. 60.-Moneywort. [L. nummulària, L.] 


\section{(I) Genus Períploca, L.}

From two Greek words meaning " twining."

Resembling Fig. 61.-Twining Milkweed. [P. Gràca, L.]

Flowers, dark purple, in long axillary clusters. Corolla, flat wheel-shape. Petals, united, very narrow, pointed, very hairy within. Calyx, minute. Sepals, united, narrow, pointed. Stamens, with filaments distinct. Anthers, cohering, and bearded along the back. Throat of the corolla surrounded by a five-parted crown, each lobe tipped with a slender bristle.

Leaves, three to four inches in length, egg-shape, pointed. Leaf-stem, one third inch in length.

Fruit, about two inches in length, smooth, many-seeded. Seeds, hairy. A follicle.

Found, in cultivation, from which it has escaped sparingly in Western New York.

A woody climber ten to fifteen feet in length.

\section{(2) Genus Vincetóxicum, Moench.}

From two Greek words meaning " binding " and "poison."

Fig. 61.-Black Milkweed. [V. nigrum, Moench.]

Flowers, small, dark purple, in axillary clusters, each cluster on a stem shorter than the leaves. Corolla, flat wheel-shape, five-parted, the crown above its throat a fleshy five- to ten-lobed, flat-disk.

Leaves, egg-shape to lance-shape, nearly smooth.

Fruit and seeds, smooth.

Found, as a weed escaped from cultivation from New England to Pennsylvania.

A more or less twining herb. 


\section{(3) Genus Gonólobus, Moench.}

From two Greek words meaning "angled" and "pod," with reference to the angular fruit of some of the species.

Fig. 62.-Rough-Fruited Milkweed. G. obliquus, R. Br.

Flowers, dull or greenish outside, purplish within, in many-blossomed clusters. Corolla, five-parted, wheelshape; in bud, long cone-shape; its lobes five sixths to one half inch in length and one twelfth of an inch in width; minutely downy within; the crown in its throat a fleshy ring. June, July.

Leaves, three to eight inches in length, round to eggshape. Base, heart-shape. Apex, abruptly pointed.

Fruit, rough with hard short points.

Found, along the banks of streams from the mountains of Pennsylvania and Virginia to Ohio and Missouri.

A climbing or trailing herbaceous vine three to five feet in length.

No. 18.-Family CONVOLVULÀCEÆ. (Convolvulus Fam.)

Flowers, mostly showy, on axillary flower-stems. Corolla, five-lobed, but with the edge so nearly even that the lobes are scarcely more than indicated,--excepting in Dodder (No. 4), which is more deeply lobed, and sometimes is in fours instead of fives throughout. Calyx, five-lobed or parted,--excepting sometimes in Dodder (No. 4). Stamens, of the same number as the lobes of the corolla, and alternate with them. Styles, one or two. Seed-case, free, two-celled, with two young seeds in each cell; or four-celled by false partitions. 
Leaves, simple, alternate, entire or lobed; or, in Hedge Bindweed (No. 2), sometimes slightly toothed at the base; and, in Dodder (No. 4), lacking, or replaced by scales.

Fruit, rounded, two- to four-celled; or, in Convólvulus (No. 2), sometimes one-celled by absorption. Seeds, two to six. A capsule.

Twining or prostrate herbaceous vines, Many species of the family have been introduced and cultivated for ornament $\left(e_{.} g_{*}\right.$, the Moon-floor), some for use $\left(e_{.} g_{\text {. }}\right.$, the Sweet Potato).

GUIDE TO THE GENERA.

(a) Leafy.

(b) Style, undivided. Stigmas, I to 3 , blunt to globular. Leaves, heart-shape or lobed. Ipomæaa (Morning-Glory, etc.)

(b) Style, undivided, or two-cleft at the summit. Stigmas, two, line-like to egg-shape. Leaves, arrow-shape. (2) Convólvulus (Bindweeds).

(b) Style, two-cleft. Stigmas, two, blunt. Leaves, narrow, tapering to the base. (3) Brewèria (Breweria).

(a) Leafless, parasitic, never green. (4) Cúscuta (Dodder)

\section{(I) Genus I томc̈a, L.}

Flowers, from salver-form or funnel-form to nearly bellform; one to five blossoms for each cluster-stem. Corolla, with its edges lightly lobed or entire. Calyx, with the outer sepals usually the largest. Bract, absent; neither on the flower-stem nor covering the calyx. Style, one, undivided. Stigmas, one to three, short and blunt to globular. 


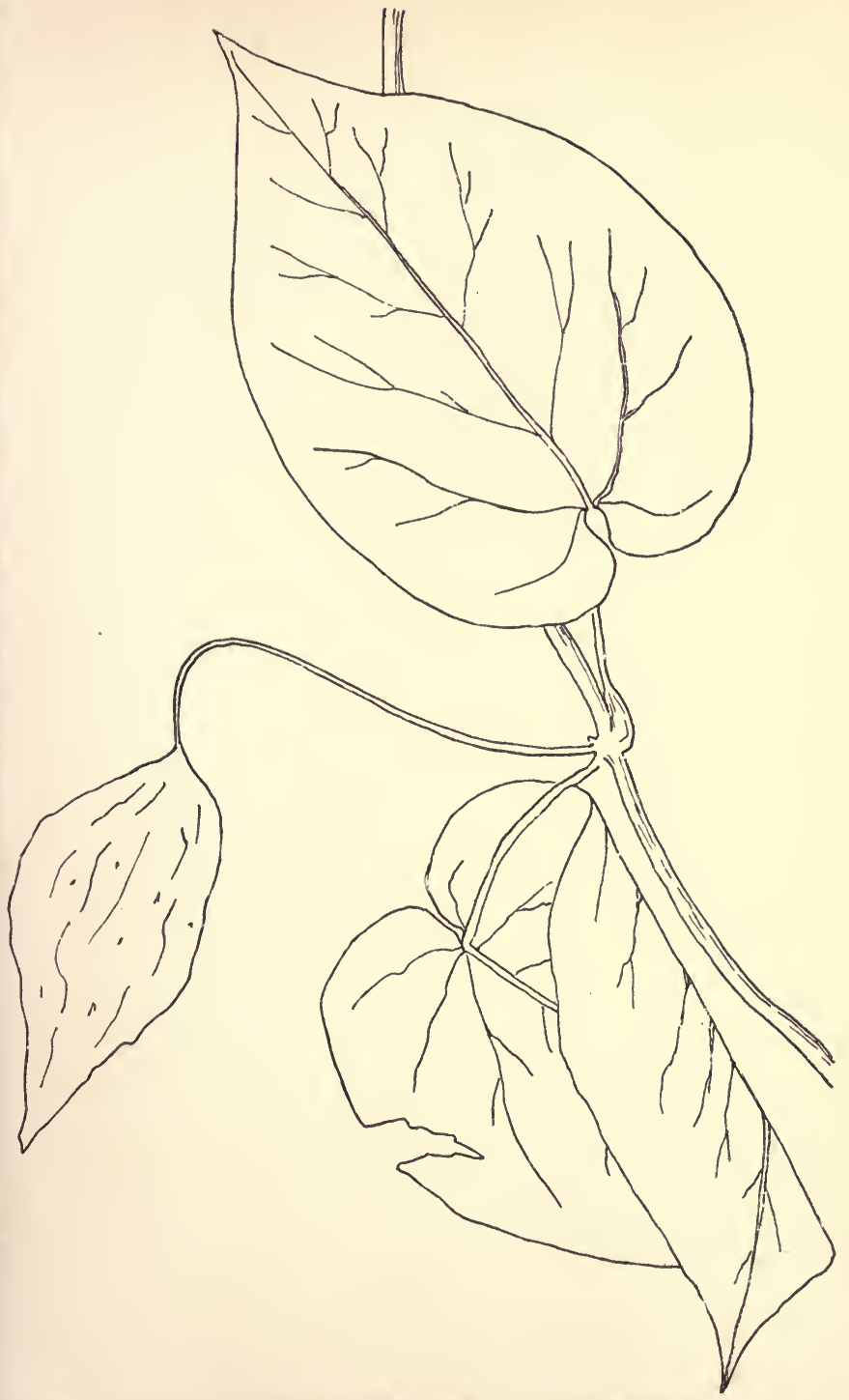

129 Fig. 62.-Rough-Fruited Milkweed. (G. obliquus, R. Br.) 
Leaves, simple, alternate, heart-shaped or lobed.

Fruit, globular, separating into two to four pieces ; cells, two to four. Seeds, four to six, or, by absorption of the ovules, fewer.

Twining or prostrate herbaceous vines.

Fig. 63.-Morning-Glory. [I. purpùrea, Lam.]

Flowers, two inches in length, funnel form, of various colors from purple to white. Corolla, twisted in the bud. Calyx, hairy below. Sepals, long, narrow, tapering. Stamens and style, not exserted. Stigma, three-lobed. Seed-case, three-celled. Cluster-stems, long, with two to five blossoms.

Leaves, broad, egg-shape to rounded, with the base heartshape and the apex pointed. Leaf-stem, hairy.

Fruit, three-celled.

Found, escaped from gardens, and very common in cultivation.

A rapid.growing, herbaceous vine, rough with downward-pointing hairs, climbing by twisting. It is one of the oldest and commonest and best liked of the familiar garden flowers. It is a native of tropical America.

Fig. 64.-Small Morning-Glory. [I. hederàcea, Facq.]

This species differs from the preceding chiefly in the following items : 


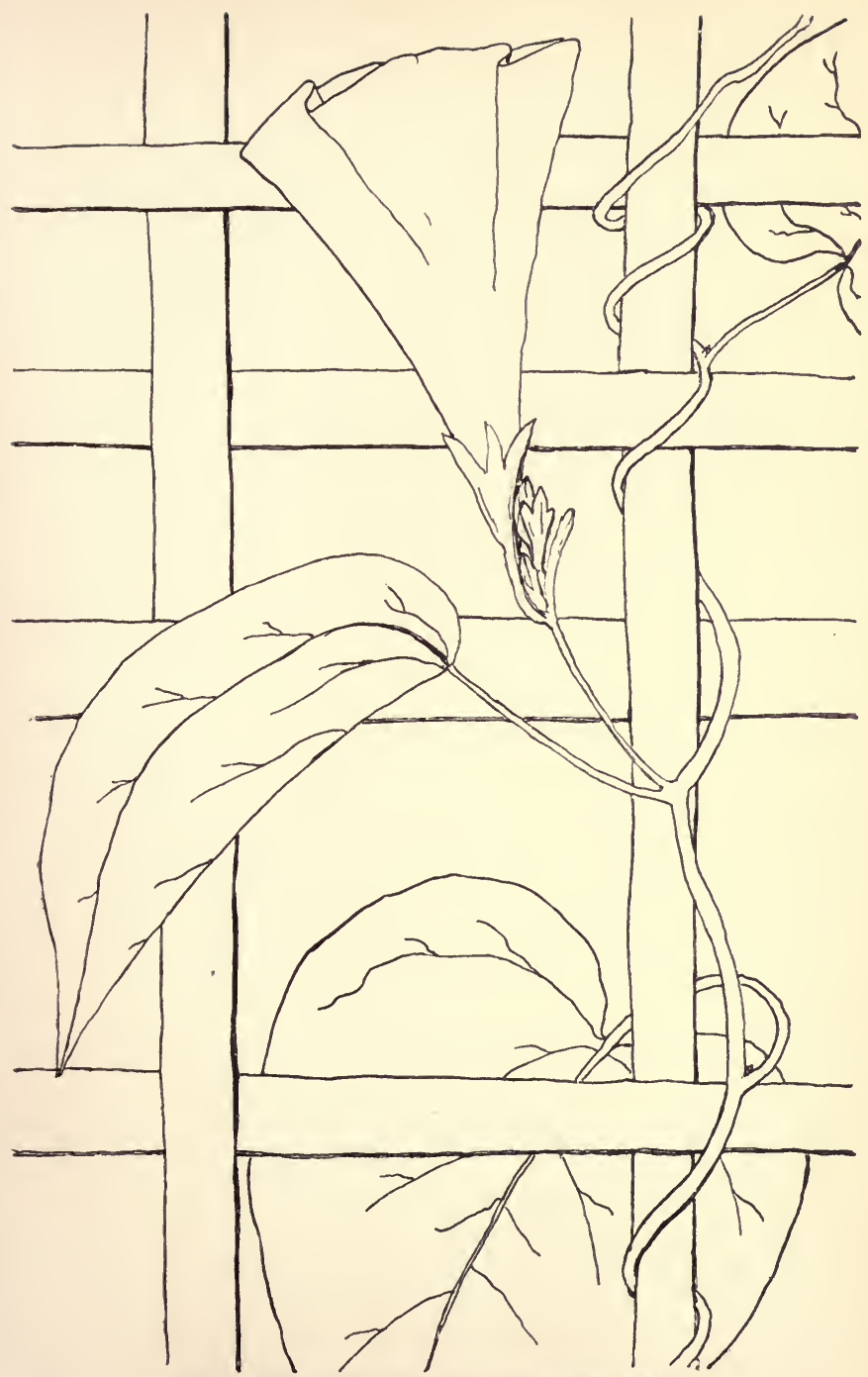

Fig. 63.-Morning-Glory. [I. purpùrea, Lam.] 
Flowers, one to one and one half inches in length. Calyx, densely hairy below. Cluster-stem, with one to three blossoms.

Leaves, sometimes heart-shaped, but usually variously three-lobed, the lobes pointed.

Found, escaped from cultivation, from Pennsylvania southward.

Stems, usually prostrate and one to one and a half feet long.

Fig. 65.-Wild Cypress-Vine. [I. coccinea, $L$.]

Flowers, one inch in length, light scarlet or sometimes yellowish. Corolla, tubular, with a spreading salvershaped and slightly lobed border. Calyx, smooth, or nearly so. Sepals, bristle-pointed. Stamens and style, exserted. Style, one. Stigma, two-lobed. Seedcase, four-celled, four-seeded. Cluster-stem, with about five blossoms.

Leaves, variable, heart-shaped. Apex, pointed. Edge, entire, or sometimes lobed and angled toward the base. Base, lobes sometimes rounded and sometimes pointed.

Fruit, four-celled, four-seeded.

Found, escaped from cultivation, from Ohio and Illinois southward. Probably native in New Mexico and Arizona.

A pretty twining vine with delicate flowers. It is not as common in cultivation as the associated species [ $I$. Quámoclit, L.], which has a similar blossom, but a very different leaf-deeply parted and feather-like. 

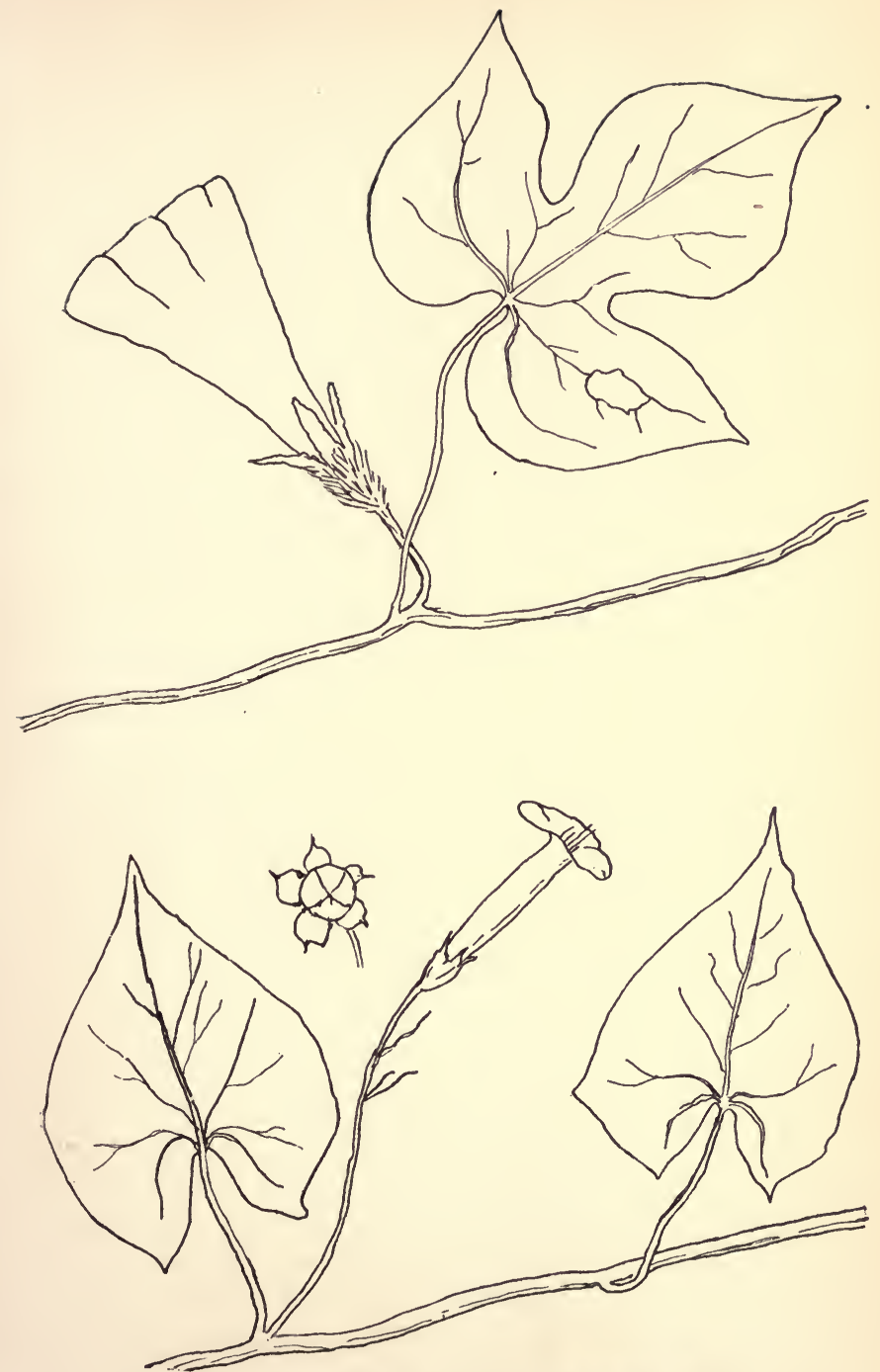

Fig. 64.-Small Morning-Glory. [I. hederàcea, Jacq.] Fig. 65.-Wild Cypress-Vine. [I. coccínea, L.] 
Resembling Fig. 63.-Wild Potato-Vine. Man-of-the-Earth. I. panduràta, Meyer.

Flowers, about three inches in length; white, with the tube purple within; broad funnel-shape. Corolla, three or four times longer than the calyx. Sepals, smooth, egg-shape to oblong, very blunt, the two. outer ones shortest. Stamens and style, not exserted. Stigma, two-lobed or entire, somewhat globose. Cluster-stem, with one to five blossoms. June to. August.

Leaves, two to three inches in length, heart-shape, usually pointed at the apex, entire, or sometimes contracted at the sides to lobed and fiddle-shape.

Fruit, two-celled. Seeds, four, woolly on the angles.

Found, oftenest in dry ground, from Connecticut to Michigan and southward to Florida and Texas.

A twining or sometimes trailing herbaceous vine, with stems four to eight feet in length ; several stems usually springing from one huge tuberous and woody root that often weighs from ten to twenty pounds.

"This root has long been employed in domestic medicine, and is a favorite remedy of some botanic doctors. It is bitterish and somewhat astringent."-Torrey.

Resembling Fig. 65.-White Star-Ipomòa. I. lacunòsa, L.

Flowers, about one inch in length, or less, bell-shape. Corolla, white, sometimes with a purplish edge, sharply five-lobed, about twice the length of the calyx. Sepals, lance-shape to oblong, pointed, hairy. Stamens and style, not exserted. Stigma, two-lobed or entire. Cluster-stem, much shorter than the leafstem, usually about one half as long, with one to three blossoms. August, September. 


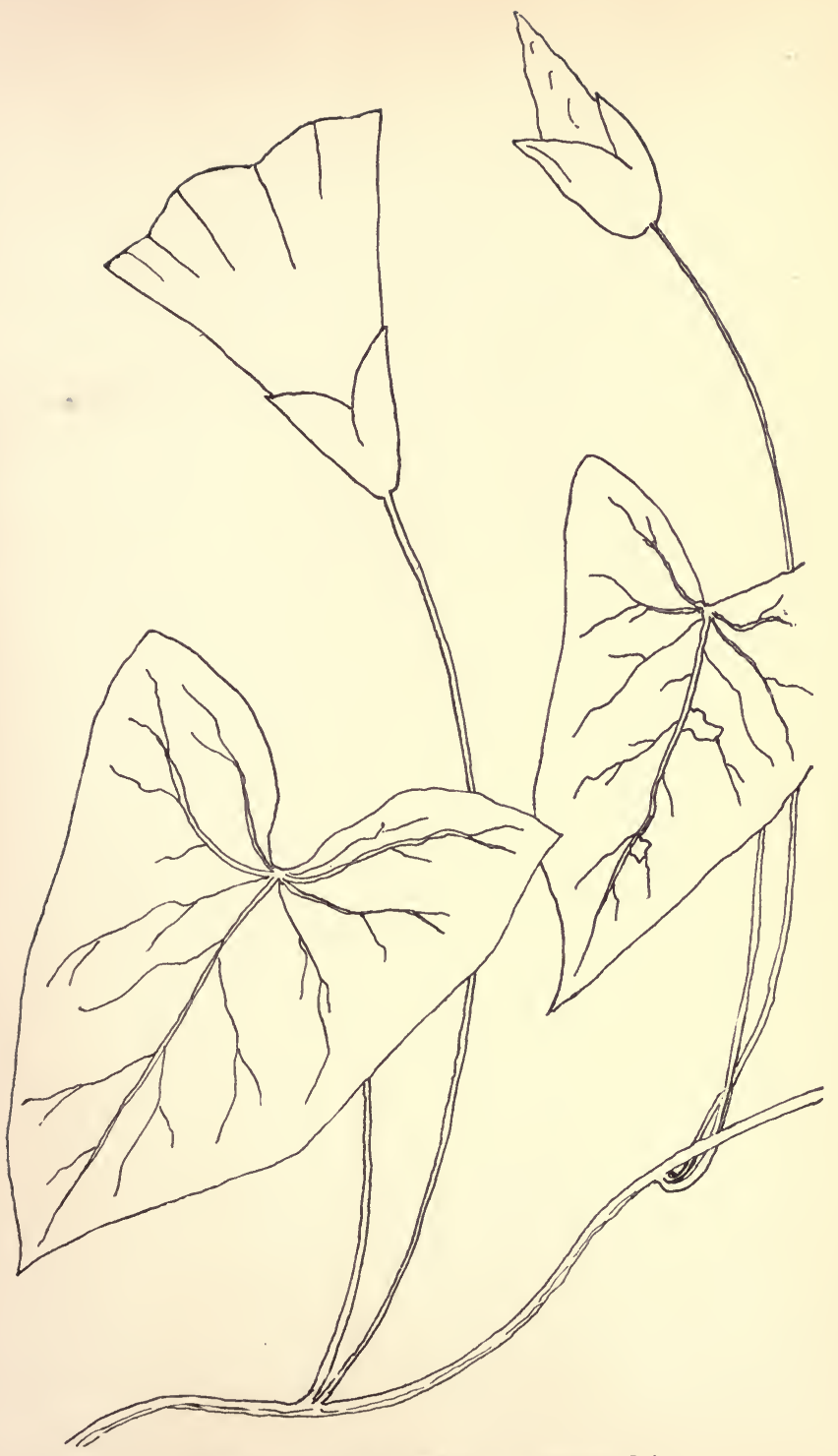

Fig. 66.-Hedge Bindweed. (C. sèpium, L.) 
Leaves, about two inches in length, heart-shaped to threelobed, pointed at the apex.

Fruit, two-celled, four-seeded.

Found, oftenest in low ground from Pennsylvania to Illinois and southward to South Carolina and Texas.

A twining or prostrate vine, herbaceous, slender, smoothish, two to six feet in length.

(2) Genus Convólvulus, Tourn. (Bindweeds.)

From a Latin word meaning " to entwine."

Flowers, funnel-shape to bell-shape. Petals, united. Bracts, present, covering the calyx, or minute on the flower stem. Stamens, not exserted. Style, one, undivided or two-cleft at the apex. Stigmas, two, linelike to egg-shape.

Leaves, simple, alternate more or less arrow-shape.

Fruit, round, two-celled, or one-celled by absorption of the partition. Seeds, four.

Twining or prostrate herbaceous vines.

Fig. 66.-Hedge Bindweed. Rutland Beauty. C. sèpium, L.

Flowers, white or rose-tinted. Corolla, one and a half to two inches in length. Calyx, five-parted, with two large leaf-like bracts entirely covering it, the bracts heart-shaped at their base, and at their apex usually pointed, sometimes varying to very blunt. Stamens, widened and feathered toward the base, not exserted. Flower-stem, four-angled, one-flowered, as long as the leaf-stem, or longer. June, July. 

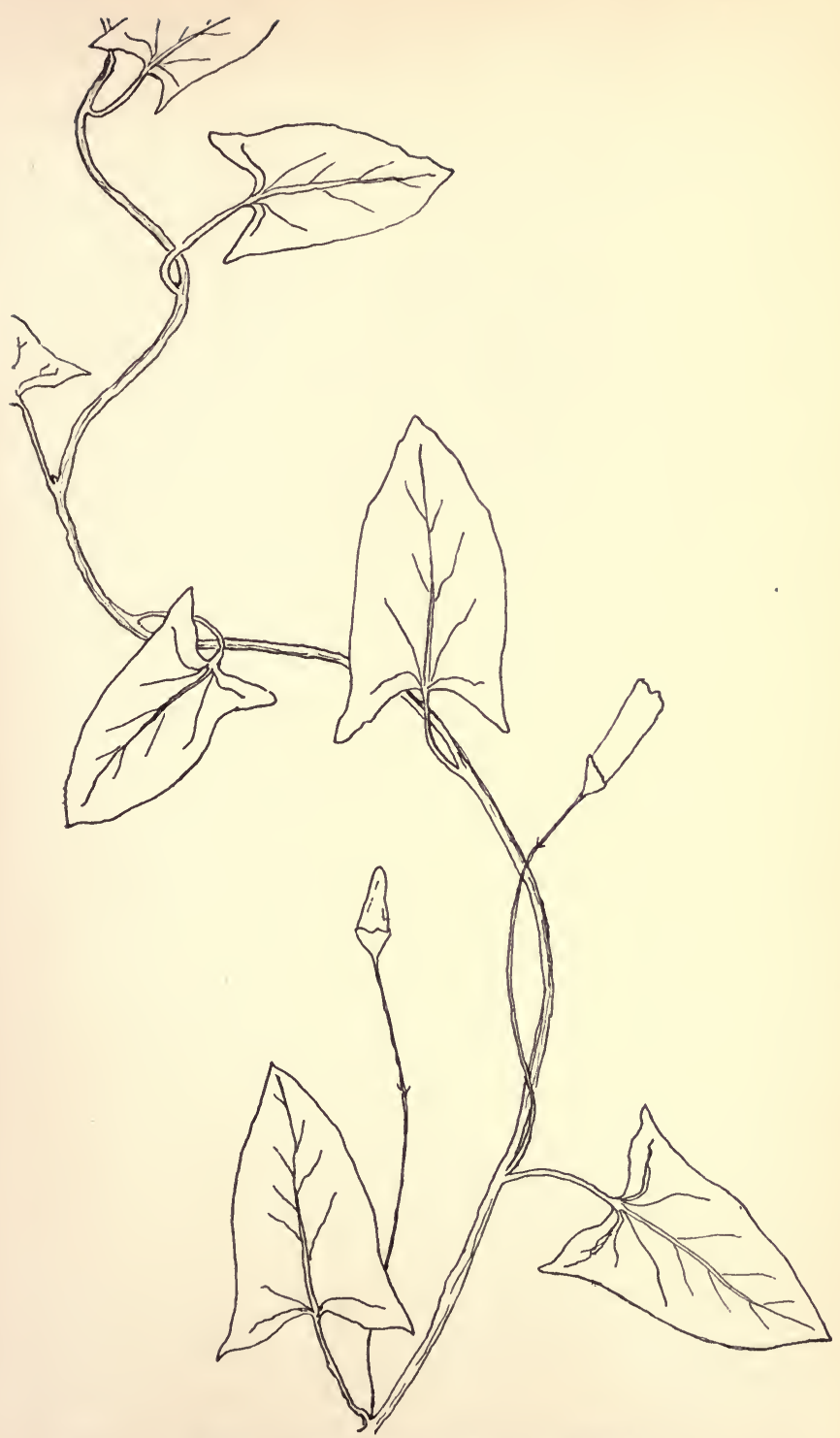

Fig. 67.-Field Convolvulus. [C. arvénsis, L.] 
Leaves, two to four inches in length, more or less arrowshaped. Apex, pointed. Base, lobed, the lobes often cut obliquely, and sometimes slightly toothed or wavy.

Fruit, one-celled or imperfectly two-celled, four-seeded.

Found, in rich moist ground from North Carolina northward and westward.

An extensively twining or sometimes prostrate vine, five to eight feet in length, smooth, or sometimes varying to downy.

In parts of England the blossom of the Bindweed is named Old Man's Night-Cap, as that of the White Campion is named Grandmother's Night-Cap.

Fig. 67.-Field Convolvulus. [C. arvénsis, $L$.]

This species differs chiefly in the following items :

Flowers, three quarters inch in length. Bracts, minute, pointed near the middle of the flower-stem.

Leaves, variable, the lobes at the base pointed.. Stem, slightly hairy, several feet in length.

Fruit, two-celled.

Found, not common, escaped, in old fields from North Carolina to Maine.

The Field Convolvulus "has taken possession of many of our old fields, where it proves troublesome to farmers." -TORREy. 


\section{(3) Genus Brewèria, R. Br.}

From the name of an English botanist of the eighteenth century.

Fig. 68.-Breweria. B. Pickeringii, G.

Flowers, white, small, bell-shape. Corolla, five-angled more or less silky on the outside. Sepals, very hairy. Stamens and style, exserted. Styles, two, united to above the middle. Stigmas, blunt. Flower-stems, with one to three blossoms and narrow leaf-like bracts which are as long as the flowers or longer.

Leaves, simple, alternate, entire, very narrow, line-like, or the lower ones widened toward the apex and tapering to the base, nearly stemless.

Found, from the dry pine-barrens of New Jersey to North Carolina, and, more sparingly, westward.

A prostrate herbaceous vine, smoothish or soft-downy.

\section{(4) Genus Cúscuta, Tourn. (Dodder, Love Vine.)}

Flowers, about one twelfth to two twelfths of an inch in length, whitish, in clusters. Corolla, from globular to tubular, with a five-cleft or four-cleft spreading border. Calyx, five-cleft or four-cleft, or of five distinct sepals. Stamens, alternate with the lobes of the corolla, and with scale-like, often fringed, attachments at their base. Styles, two, distinct or united. Seed-case, two-celled. Blossoming usually in the summer and fall.

Leaves, lacking; in place of them usually a few scattered, minute scales. Stems, thread-like.

Fruit, two-celled, mostly four-seeded. 
A delicate parasite, whitish to yellowish or to light reddish in every part, appearing more like a tangle of thread than a living plant. The seeds germinate in the ground; then throw up slender stems which soon wither at the root; but the vine continues its growth over neighboring plants, clinging to them and feeding upon them by help of minute suckers. It is a true parasite, living thus upon other forms of vegetation, sometimes very greatly to their injury.

The name "Dodder" is said to be the ancient Frissian name, and to signify a tangled hank of silk, such as the stalks often suggest.

In England other names are given to the Dodder : one, and not a pleasant one, is "Devil's gut," because of the slender stems twining around other plants as though to strangle them. Another name is "Strangle-tare"; another, "Lady's-lace."

In a curious poem written nearly a hundred years ago, Dr. Erasmus Darwin comments :

" The fair Cuscutæ please

With labored elegance aud studied ease.

With sly approach they spread their dangerous charms, And round their victims wind their wiry arms.

So by Scamander when Laocoön stood, Where Troy's proud turrets glittered in the flood, Two serpent forms . . .

Ring above ring in many a tangled fold Close and more close the writhing limbs surround And fix with foamy teeth the envenomed wound." 


\section{GUIDE TO THE SPECIES.}

(a) Stigmas, rounded or blunted. Seed-case, not splitting when ripe.

(b) Calyx with united sepals. Seed-case, flattened at the apex.

(c) Flowers in dense rounded clusters. Corolla with a short and wide tube. (I) C. chlorocárpa (GreenFruited Dodder). (2) C. arvénsis (Field Dodder).

(c) Flowers in lengthened or angled clusters. Corolla with a long slender tube. (3) C. tenuiflòra (Narrow-Flowered Dodder).

(b) Calyx with united sepals. Seed-case pointed at the apex.

(c) Corolla-lobes pointed and turned in. (4) C. decòra and var. (Comely Dodder). (5) C. infléxa (Bending Dodder).

(c) Corolla-lobes blunt and spreading. (6) C. Gronòvii and var. (Gronovius' Dodder).

)b) Calyx with five distinct sepals. (7) C. compácta (Compact Dodder). (8) C. glomeràta (Coiled Dodder).

(a) Stigmas lengthened. Seed-case splitting when ripe. (9) [C. epílinum] Flax Dodder. (ro) [C. epíthymum] Thyme Dodder.

(I) Green-Fruited Dodder. C. chlorocárpa. Eng.

Flowers, one twelfth inch, or a little more in length, in dense, rounded clusters. Corolla, with a short and wide tube. Corolla-lobes and calyx-lobes, usually fourpointed, often longer than the tube. Scales, at the base of the stamens, small and two-cleft, or oftener reduced to minute teeth.

Stem, coarse, orange color.

Fruit, globular, with depressed apex; pale, greenishyellow.

Found, in damp ground from Wisconsin to Arkansas, also in Pennsylvania and Delaware.

A favorite support is the common Knotweed. 
(2) Field Dodder. C. arvénsis, Bey.

Flowers, scarcely one twelfth inch in length, five-parted, in dense, rounded clusters. Corolla, with a short and wide tube. Corolla-lobes, longer than the tube, pointed, with the ends turned in. Calyx-lobes, blunt and usually very broad. Scales, at the base of the stamens, large and deeply fringed.

Stem, pale and slender, scarcely one foot in length.

Fruit, globular, with depressed apex, yellowish.

Found, on rather dry soil, from New York to Florida, and westward to the Pacific. Very variable.

(3) Slender-Flowered Dodder. C. tenuifiora, Eng.

Flowers, one twelfth inch in length, or less, usually fourparted, in lengthened or angled clusters. Corolla, with a slender tube deeply bell-shaped, the tube usually longer than the lobes. Corolla-lobes, and calyx-lobes, oblong and blunt. Scales, at the base of the stamens, shorter than the tube and fringed.

Stems, coarse, yellow.

Fruit, one twelfth inch or a little more in diameter, globose with depressed apex.

Found, in wet ground, from Pennsylvania westward and southward. Favorite supports are button-bushes, tall asters, etc.

(4) Comely Dodder. C. decòra, Eng.

Flowers, one eighth inch in length or a little more, fleshy and sometimes slightly rough, broad bell-shape, in loose clusters. Corolla-lobes, five, spreading or erect, with the pointed tips turned in : egg-shape to lance. shape. Edges, minutely round-toothed. Calyx-lobes, triangular, pointed. Scales, large, deeply fringed. 
Stem, coarse.

Fruit, pointed, enveloped by the persistent corolla.

Found, in open wet ground from Illinois to Florida and Texas and westward. Favorite supports are low plants, oftenest of the Leguminòsæ and the Compósitæ Families.

Var. pulcherrima, Eng., has larger flowers, one eighth to one quarter inch in length and width, with yellow or purple anthers and stigmas.

(5) Bending Dodder. C. infléxa, Eng.

Flowers, one twelfth inch in length, fleshy, bell-shape, in loose clusters. Corolla-lobes, usually four, erect with the pointed tips turned in. Edges, minutely roundtoothed. Sepals, united. Scales, at the base of the stamens, minute, reduced to a few teeth.

Fruit, brownish, pointed, often with the withered corolla at its summit.

Found, in dry ground from southern New England to Nebraska.

Fig. 69.-(6) Gronovius' Dodder. C. Gronòviz, Willd.

Flowers, very variable in size, usually from a little over one twelfth to one eighth inch in length, in loose clusters. Corolla, bell-shape, the tube longer than the lobes and longer than the calyx. Corolla-lobes, mostly five, spreading, blunt. Sepals, united. Scales, at the base of the stamens large, oval, and abundantly fringed. August, September.

Stems, light orange, coarse, often high climbing. 
Fruit, globose or oval, brown, with a stout boss-like projection at the apex. Corolla persistent at the base.

Found, in wet and shaded grounds from Canada westward, and southward to Florida and Texas. Our most common species; the only one found throughout New England.

Var. latiflòra, Eng., has more delicate flowers with the tube of the corolla shortened, and its lobes lengthened to about the same dimensions; with narrow scales. Common northward.

(7) Compact Dodder. C. compácta, Fuss.

Flowers, stemless, in close, compact clusters. Corolla, with a cylindrical tube. Corolla-lobes, five, spreading, oblong, blunt. Sepals, five, separate, rounded, hollowed, and slightly round-toothed, surrounded by three to five similar bracts. Scales, at the base of the stamens, large and deeply fringed. July to September.

Fruit, somewhat pointed, often with the withered corolla at its summit.

Found, from Ontario, along the west side of the Alleghany Mountains to Alabama and Texas, nearly always on shrubs-Hazel, Alder, etc.

(8) Coiled Dodder. C. glomeràta, Choisy.

Flowers, stemless, in very dense continuous clusters. Corolla, tubular. Corolla-lobes, five, oblong to lanceshape, usually blunt, spreading or reflexed. Sepals, five, one twelfth inch in length, separate, oblong, their tips recurved, shorter than the tube of the corolla, surrounded by numerous similar bracts. Style, several times longer than the seed-case. Scales, large and deeply fringed. 
Found, from Ohio to Minnesota and Texas, most frequently on plants of the Compositæ Family.

The mass of knotted flowers, bracts, and stems often forms ropes one half to three quarters of an inch in thickness.

(9) Flax-Dodder. [C. epilinum, Weihe.]

This species, with the next, differs from all the others especially in these two items :

Stigmas, elongated.

Fruit, splitting when ripe.

The stamens are not exserted.

The species has been introduced from Europe where it is exceedingly hurtful in the flax-fields. It is occasionally found in the flax-fields of the northern States. June.

(I0) Thyme-Dodder. [C. epithymum, Murr.]

This species, with the preceding, differs from all others especially in these two items :

Stigmas, elongated.

Fruit, splitting when ripe.

The stamens are exserted.

The species has been introduced from Europe, and is occasionally found in beds of clover.

No. I9.-Family SOLANÀCEÆ. (Nightshade Fam.)

(r) Genus Solànum, Tourn.

The Irish Potato, Egg-Plant, Tomato, etc., belong to this very large genus.

Fig. 70.-Woody Nightshade. Bitter-Sweet. [S. dulcamàra, L.] Flowers, purple or blue in small drooping clusters along the sides of the stems. Corolla, five-parted, wheelshaped, with two greenish-white spots at the base of 


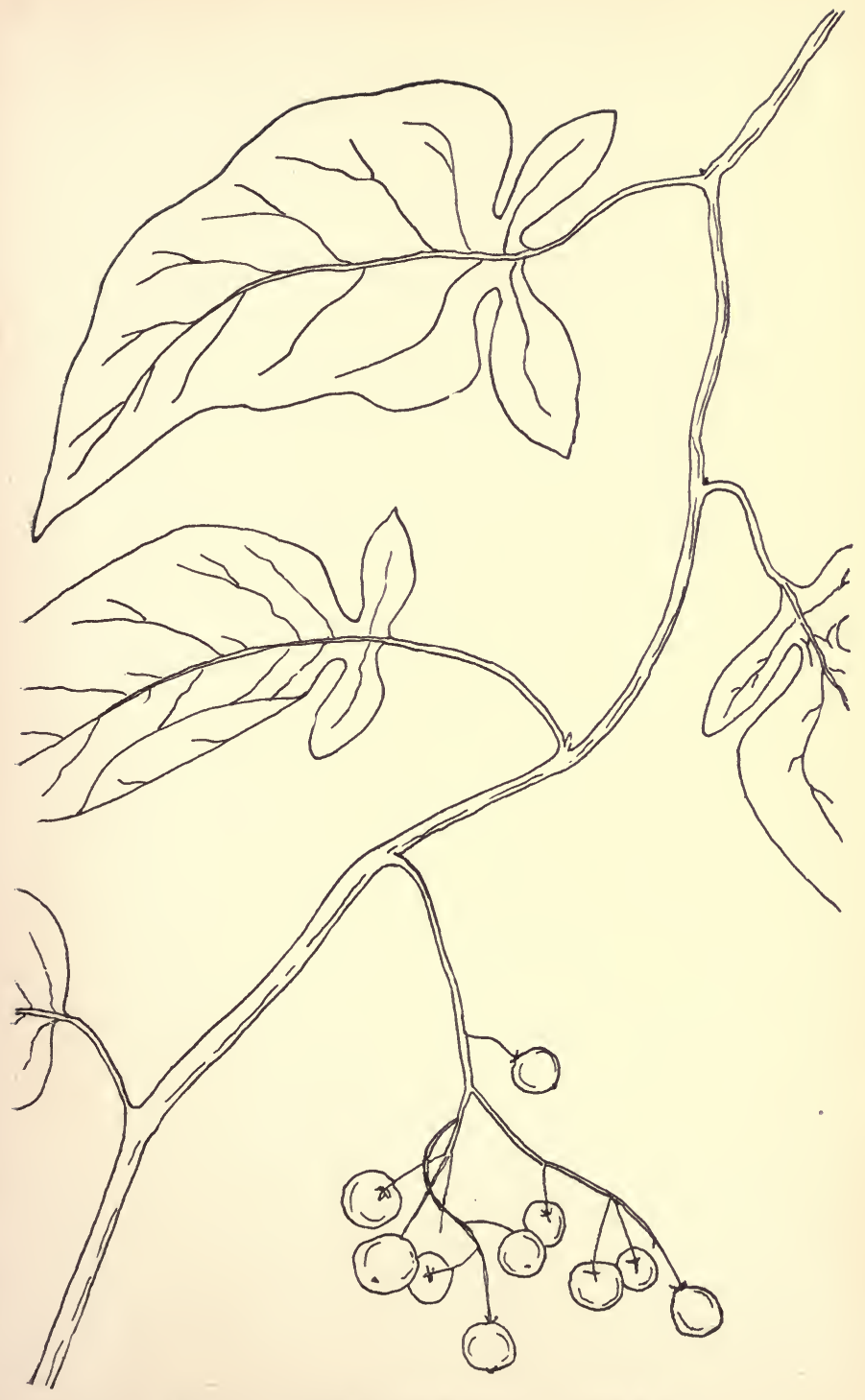

Fig. 70.-Woody Nightshade. [S. dulcamàra, L.] 
each lobe. Calyx, five-parted, persistent. Stamens, exserted, equal, with very short filaments, inserted on the corolla alternate with its lobes. Anthers, blunt, opening at the apex, united around the single style. Stigma, one. Seed-case, free, two-celled, many-seeded. June to September.

Leaves, mostly simple and egg-shape, alternate, with rank odor when crushed; the upper ones usually with two ear-like lobes or two leaflets at the base. Edges, entire. Base, usually heart-shape. Apex, pointed.

Fruit, bright red, oval, two-celled, many-seeded; in bunches that remain long after the leaves have fallen. It is said to be poisonous when eaten. A berry.

Found, in moist ground, oftenest around dwellings, from New England to Arkansas. Naturalized from Europe.

A woody climber, or trailer, sometimes five or six feet in length; not to be confused with our very different native Bitter-Sweet, $C$. scandens. It is one of the numerous plants which have lost their former reputation for high medicinal qualities. Concerning the effects of the berries. when eaten there is the most conflicting testimony. Some claim that the fruit is extremely poisonous, others that it is harmless. The rind of the stalk is said to have a taste at first bitter, then sweet, whence one of its popular names.

\section{(2) Genus Lýcium, L.}

Named from the country of Lycia, where the species was native.

Fig. 71.-Matrimony-Vine. [L. vulgàre, Dunal. L.bárbarum, L.] Fiowers, greenish-purple, solitary or in pairs from the axils of the leaves, Corolla, five-lobed, the lobes spreading. Calyx, mostly three-cleft, persistent. 


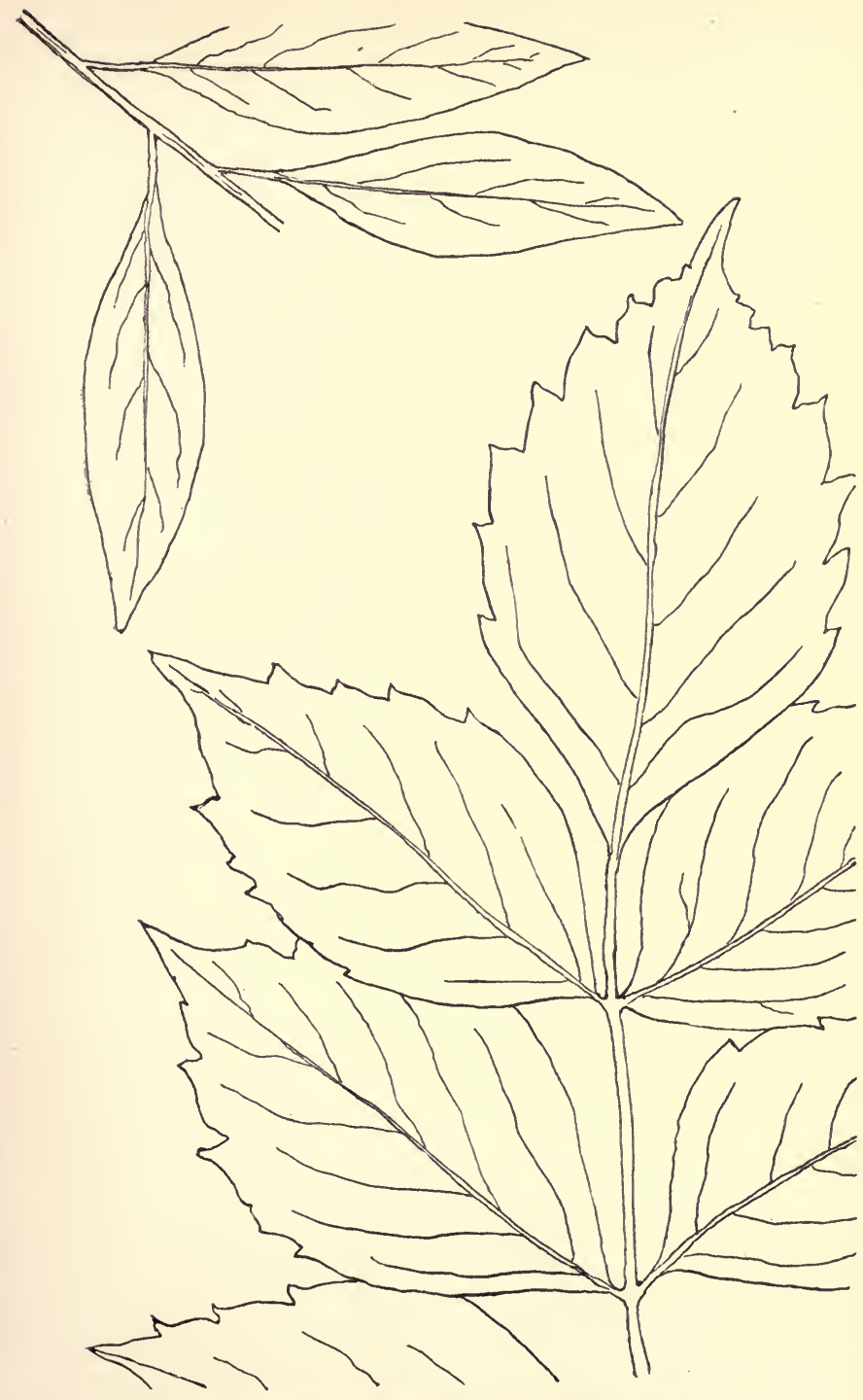

Fig. 71.-Matrimony-Vine. [L. vulgàre, Dunal.] Fig. 72.-Trumpet-Creeper. (T. rádicans, Juss.) 
Stamens, five, inserted on the corolla and alternate with its lobes, exserted. Filaments, bearded and closing the throat. Anthers, opening lengthwise. Style, one. Stigma, one. Seed-case, free, two-celled, several-seeded.

Leaves, two and a half to four inches, about three times as long as wide, simple, alternate (or of ten in clusters). Edge, entire, lance shape to oval, or sometimes widened toward the apex, smooth. Base, tapering. Apex, pointed or blunt. Stems, angled, the branches sometimes spiny, and ending in a spiny point.

Fruit, small, oval, orange-red, two-celled. Seeds, several, kidney-shaped. A berry.

Found, common in cultivation, and sparingly naturalized in Pennsylvania, etc.

A woody shrub, with long trailing or drooping branches. These branches in cultivation are often trained as screens, and when wild, cover walls and fences in thick tangled masses.

" But daintiest of all the multitude of dainties of pasture, wood, and meadow, is the nectar of flowers.

I remember how when a child, if I wished an Olympian feast, I sought the flowers of the queer, ungraceful old Matrimony Vine, which, for some unknown reason, gained so much favor with housewives, who carefully trained it over porch or trellis or against the side of the house, yet were always complaining at the litter of the constantly falling leaves. . . . By squeezing the short tube of a freshly opened flower-the faded buff ones were passed by - a generous sweet drop was secured." -- AtLantic Monthly, September, I893. 
No. 20]

No. 20.-Family BIGNONIÀCEÆ. (Bignonia Fam.)

Genus Técoma, Juss.

Fig. 72.-Trumpet-Creeper. Trumpet-Flower. T. rádicans, Fuss.

Flowers, two and a half to three inches in length, scarlet without, orange within, in terminal clusters. Corolla, funnel-form, with short tube, five-lobed, slightly irregular. Calyx, bell-shape, five-toothed, about half the length of the corolla. Stamens, four (with rudiments of a fifth), inserted on the corolla, not protruding. Anther-cells, diverging. Style, one, slender. Stigma, two-lipped. Seed-case, free, two-celled, manyseeded. June, August.

Leaves, compound, opposite. Leaflets, nine or eleven, two to three inches in length, egg-shape to oval. Edges, coarse-toothed. Apex and base, pointed.

Fruit, five to six inches in length, curved, two-celled, with the partition at right angles to the flattened sides, a section showing the figure of a cross. Seeds, many, flat, winged across. A capsule.

Found, in moist soil, from Pennsylvania and Virginia, southward to Florida and Texas. Common at the north in cultivation.

A vigorous woody climber, sometimes mounting to the height of twenty to eighty feet. In cultivation it perhaps shows to best advantage when trained upon stout posts, so forming thick columns of rich foliage and bloom. It is without tendrils, climbing by help of numerous short rootlets at the joints. 


\section{No. 21.-Family LABIÀT Æ. (Mint Fam.)}

\section{Genus Népeta, L.}

Fig. 73.-Gill-over-the-Ground. Ground-Ivy. [N. Glechoma, Benth.]

Flowers, light blue, in loose clusters of about three blossoms, from the axils of the leaves. Corolla, tubular below, two-lipped, the upper lip erect, two-notched and somewhat hollowed; the lower lip spreading, three-cleft, with the middle division largest and entire or two-lobed. Calyx, obliquely five-toothed, about one third the length of the corolla, tubular. Stamens, four, in pairs, attached to the corolla, and ascending under its upper lip. Anthers, usually so placed as to form two small crosses. Style, one. Stigma, one, two-lobed. Seed-case, free, deeply four-lobed around the stigma, each lobe containing one young seed. May.

Leaves, simple, opposite, rounded, one inch or less across, round-toothed. Apex, rounded. Base, heart-shaped.

Fruit, composed of four clustered and separable nutlets or achenes.

Found, common in damp and shaded ground. Introduced from Europe.

A creeping herbaceous vine from a few inches to two feet in length; with square stems, as in all the Labiàta, and foliage that is aromatic when crushed.

"Boiled in mutton-broth it helpeth weake \& akeing backs."-GERARD. 


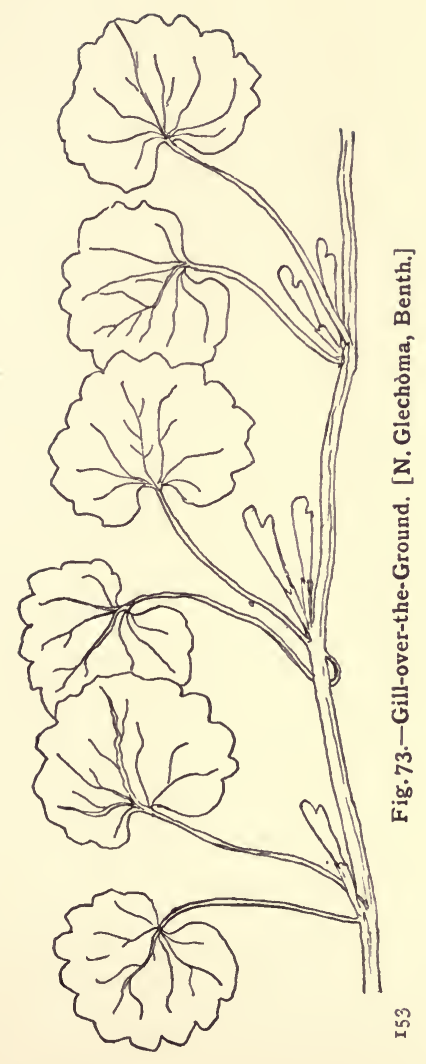





\section{CLASS FIRST-Continued (EXOGENS)}

\section{DIVISION III}

THE COROLLA LACKING

(APETAlous) 



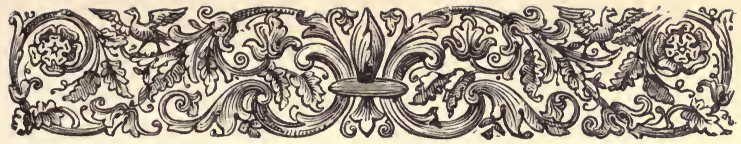

No. 22.-Family POLYGONÀCEÆ. (Buckwheat Fam.)

(I) Genus Polýgonum. (Knotweeds.)

From two Greek words meaning " many" and "knees," because of the jointed stems.

Flowers, in clusters. Corolla, lacking. Calyx, five- (rarely four-) parted, mostly greenish-white with colored margins, more or less corolla-like in appearance, persistent. Stamens, usually eight, rarely five, and in No. I (P. arifòlium) six. Styles or stigmas, three, (two in No. I). Seed-cases, free, one-celled, oneseeded.

Leaves, simple, alternate, entire. Stipules, (ocreæ) in the form of sheaths around the stem at the swollen joints.

Fruit, enclosed, or nearly enclosed, by the calyx, onecelled. Seed, one, flattened or triangular. An achene.

All herbaceous.

GUIDE TO THE SPECIES.

(a) Stems prickly.

(b) Leaves halberd-shaped. Stamens six, styles two. (I) Halberd-leaved Tear-Thumb (P. arifòlium, L.). (b) Leaves arrow-shaped. Stamens mostly eight, styles three. 
(2) Arrow-leaved Tear-Thumb (P. sagittàtum, L.). (a) Stems not prickly.

(b) Sheaths naked. Fruit not winged.

(3) Black Bindweed (P. convólvulus, L.).

(b) Sheaths fringed at base. Fruit not winged.

(4) Bristly-jointed Bindweed ( $\mathrm{P}$. cilinòde, Mx.).

(b) Sheaths not fringed. Fruit winged.

(5) Hedge Bindweed (S. scándens, L.).

Fig. 74.-(I) Halberd-Leaved Tear-Thumb. P. arifolium, $L$.

Flowers, small, white or pale rose, in few-blossomed spikes.

Calyx, often four-parted. Stamens, six. Styles, two, very short. June to October.

Leaves, two to four inches in length, halberd-shaped, the base a pair of spreading pointed lobes, the apex tapering and pointed. Leaf-stem, one half to one inch in length, roughened with downward-pointing prickles.

Fruit, large, flattened, the shape of a double convex lens.

Found, in low and wet ground from Canada to Georgia and westward.

A weak vine, two to three feet long, climbing by help of fine downward-pointing prickles on the edges of its grooved and often red stem.

Fig. 75.-(2) Arrow-Leaved Tear-Thumb. Scratch-Grass. $P$. sagittàtum, $L$.

Flowers, whitish or pale rose, in small heads. Stamens, usually eight. Styles, three, slender. Cluster-stems, smooth and usually reddish or nearly white. June to October.

Leaves, one to three inches in length, arrow-shape. Leafstem, short, sheathing stipules at the joints, smooth, membranaceous. 


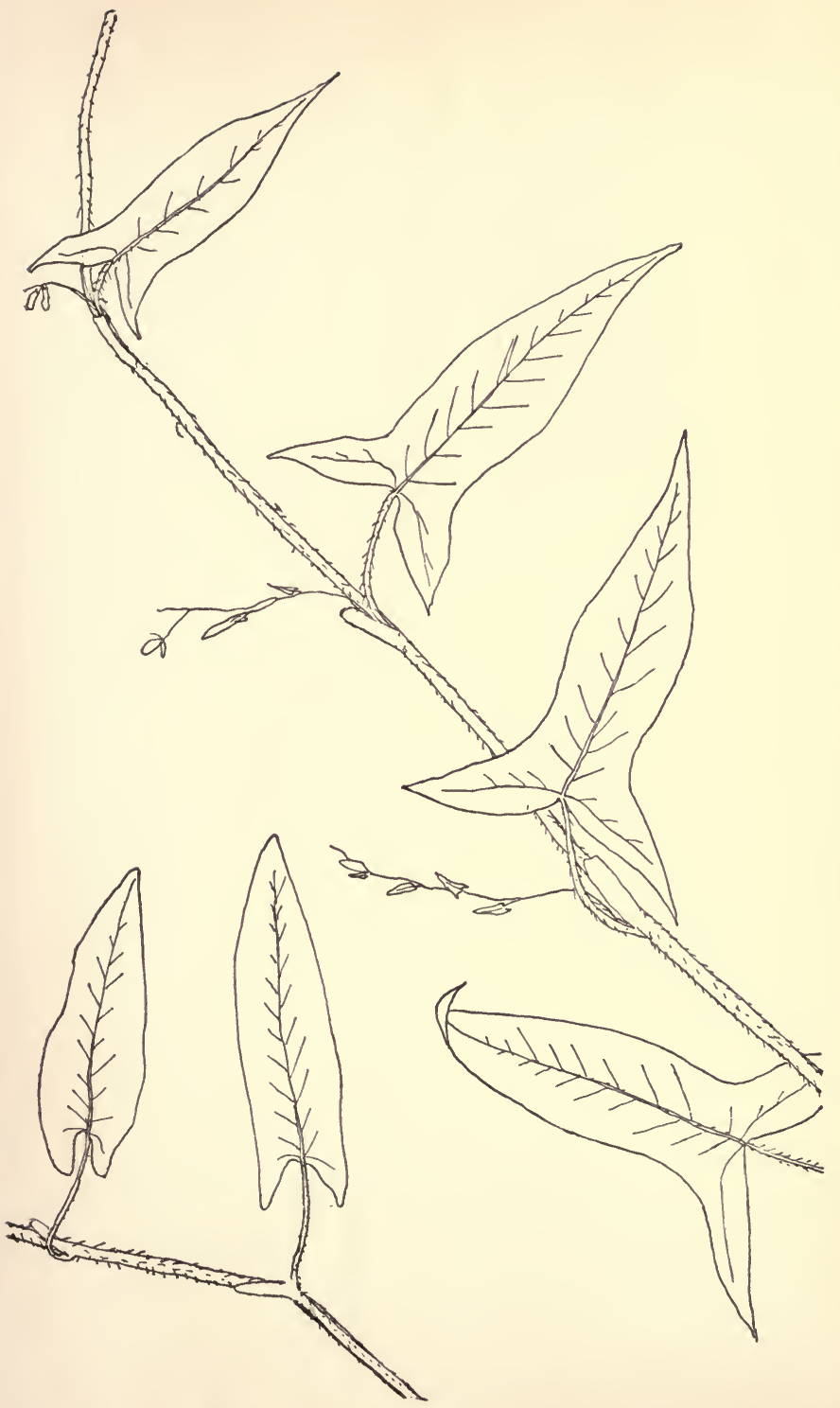

Fig. 74.-Halberd-Leaved Tear-Thumb. (P. arifolium, L.) Fig. 75.-Arrow-Leaved Tear-Thumb. (P. sagittàtum, L.) 
Fruit, sharply three-angled. Achene, nearly black, smooth, nearly as broad as long.

Found, common everywhere in low ground.

A slender, usually prostrate vine, not twining, two to five feet in length; mostly smooth, excepting on the edges of the four-angled stem, and on the mid-vein of the leaf and leaf-stem. These parts are set with fine and very sharp downward-pointing prickles.

Fig. 76.-(3) Black Bindweed. Knot Bindweed. [P. convólvulus, $L$.]

Flowers, whitish, either sessile or in small loose clusters from the axils of the leaves. Calyx, five-lobed, twice as long as the flower-stem, the three outer lobes keeled. Stamens, eight. Styles, three, very short. July and August.

Leaves, one to two inches or more in length, halberd-heartshape, tapering to the apex, with usually pointed and somewhat spreading lobes at the base. Sheathingstipules, not fringed at their base as in No. 4 (BristlyJointed Bindweed).

Fruit, three-angled, not winged around as in No. 5 (Hedge Bindweed). Achene, dull black, under the lens roughish (striate), the sides ovate-triangular to oval.

Found, common in cultivation and in waste ground from Canada to North Carolina. Naturalized from Europe.

A prostrate or climbing and twining vine, with a ridged, roughish, but not prickly stem, two to three feet in length. 

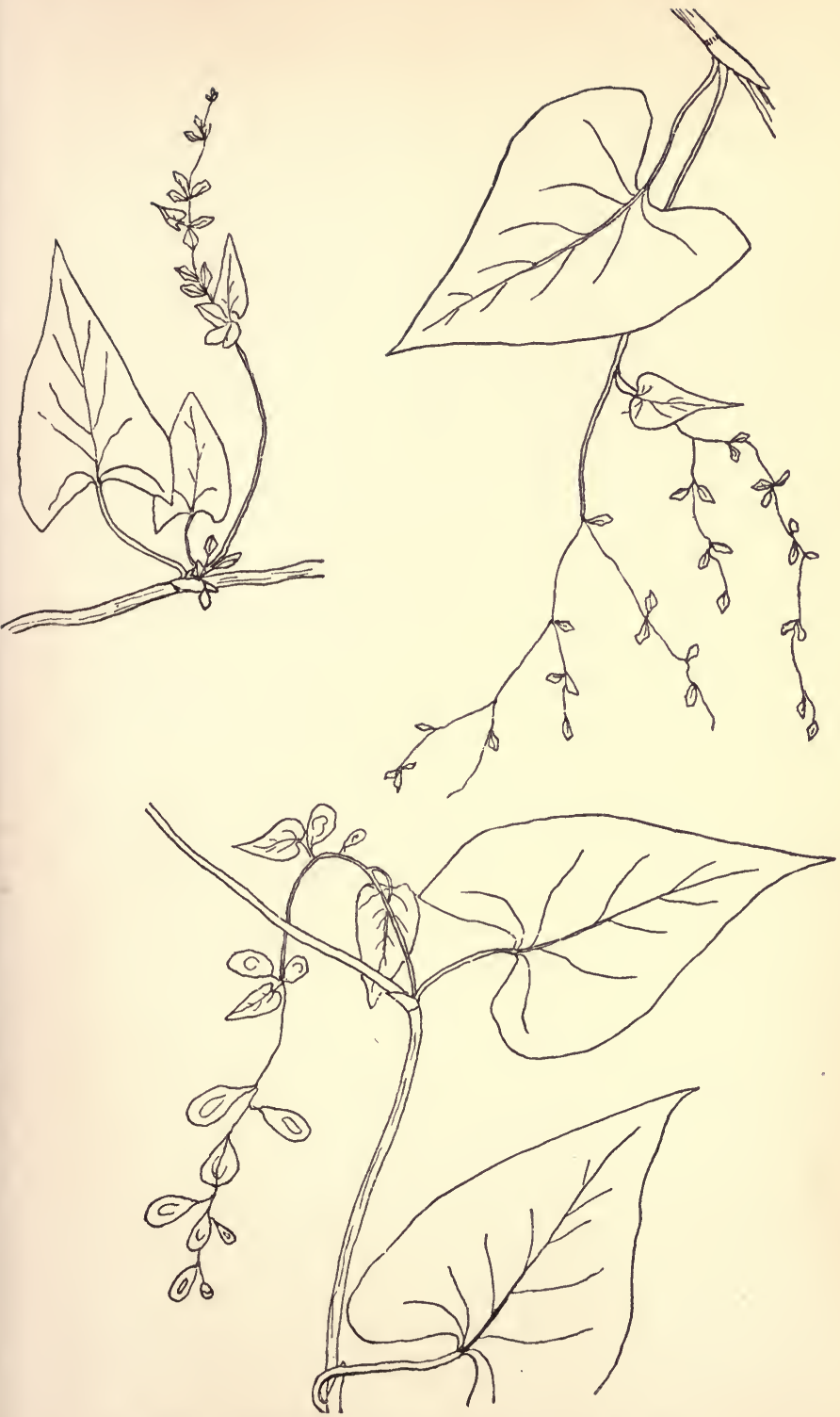

Fig. 76.-Black Bindweed. [P. convólvulus, L.]

Fig. 77.-Bristly-Jointed Bindweed. (P. cilindde, Mx.)

Fig. 78.-Hedge Bindweed. (P. scándens, L.) 
Fig. 77.-(4) Bristly-Jointed Bindweed. Bristly-Jointed Knotweed. $P$. cilindde, $M x$.

Flowers, in loose, nearly leafless clusters, five inches in length or so, at the sides and the ends of the branches. Calyx, five-lobed, the outer lobes only obscurely keeled. Stamens, eight. Styles, three, very short. July to September.

Leaves, one to one and a half inches or more in length, egg-shape, minutely downy. Apex, taper-pointed. Base, deeply heart-shaped, with the lobes sometimes slightly spreading. Sheathing-stipules, at the joints, minutely fringed at the base with reversed bristles.

Fruit, three-angled, not winged around as in No. 5 (Hedge Bindweed). Achene, very smooth and shining, the sides elliptical.

Found, in thickets and on rough hills, from Canada to the mountains of North Carolina.

A slender climbing and twining vine, minutely downy, three to nine feet in length.

Fig. 78.-(5) Hedge Bindweed. Climbing False Buckwheat. $P$. scándens, $L$.

Flowers, in interrupted, usually leafy clusters in the axils of the leaves. Calyx, five-lobed, the three outer sepals strongly keeled and becoming winged in fruit. Stamens, eight. Styles, three, very short. July to September.

Leaves, two to three inches in length, egg-shape. Apex, pointed. Base, lobed, the lobes slightly pointed, or rounded, sometimes spreading. Sheathing-stipules, not fringed at the base as in No. 4 (Bristly-Jointed Bindweed). 
Fruit, winged around like elm-seeds. Achene, smooth, black, with sides hollowed and ovate-elliptical.

Found, common in thickets from Canada to Florida and westward.

A slender vine eight to twelve feet in length, smooth, twining over high bushes; its winged fruit more showy than its blossoms.

No. 23.-Family ARISTOLOCHIÀCEÆ. (Birthwort Fam.)

\section{Genus Aristolòchia, Tourn.}

From two Greek words meaning "excellent" and "childbirth," with reference to supposed medicinal qualities.

Fig. 79.-Pipe-Vine. Dutchman's Pipe. Wild Ginger. Big Sarsaparilla. A. Sipho, L'Her.

Flowers, dull brown, solitary, along the sides of the branches. Corolla, lacking. Caly'x, one and a half inches in length, the tube inflated, and strongly curred like a large pipe ; contracted at the mouth, obscurely three-lobed, with a brown-purplish flat border. Flower-stem, long, with a clasping egrg-shaped bract near the base. Stamens, six. Anthers, in pairs, united to the three short thick lobes of the stigma. Sced-case, adherent to the calyx or partly so, six-celled, many-seeded. May, June.

Leaves, simple, alternate, entire, six to twelve inches across, broad heart-shape; sprinkled with soft hairs, othcrwise nearly smooth. Stipules, none.

Fruit, usually three to four inches in length, six-angled, six-celled. Seeds, many, very flat. A capsule. 
Found, in rich woods from Pennsylvania to Georgia, and west to Minnesota and Kansas.

A woody vine with twining stems, sometimes two inches thick, that climb to a height of thirty or forty feet ; very ornamental and useful in cultivation for arbors and screens. The root is aromatic and stimulant like ginger.

\section{No. 24.-Family URTICACEÆ. (Nettle Fam.)}

\section{Genus Hùmulus, L.}

Fig. 80.-Hop. H. Lüpulus, $L$.

Flowers, small, greenish, in clusters. The staminate and the pistillate forms are in different plants; the staminate, with five sepals and five erect stamens opposite them, in loose very many-blossomed clusters from the axils of the leaves; the pistillate, with one sepal, which is wrapped around the seed-case, in short spikes with large scales. June, July.

Leaves, variable, usually two to four inches in length, simple, opposite, toothed, and mostly three- or five-lobed, very rough backward on the upper surface. Stipules, persistent.

Fruit, one-celled, one-seeded. An achene wrapped in the enlarged scale-like calyx.

Found, only in rich soil, from New England westward, and southward in the mountains to Georgia. Also, extensively in cultivation for the markets. 


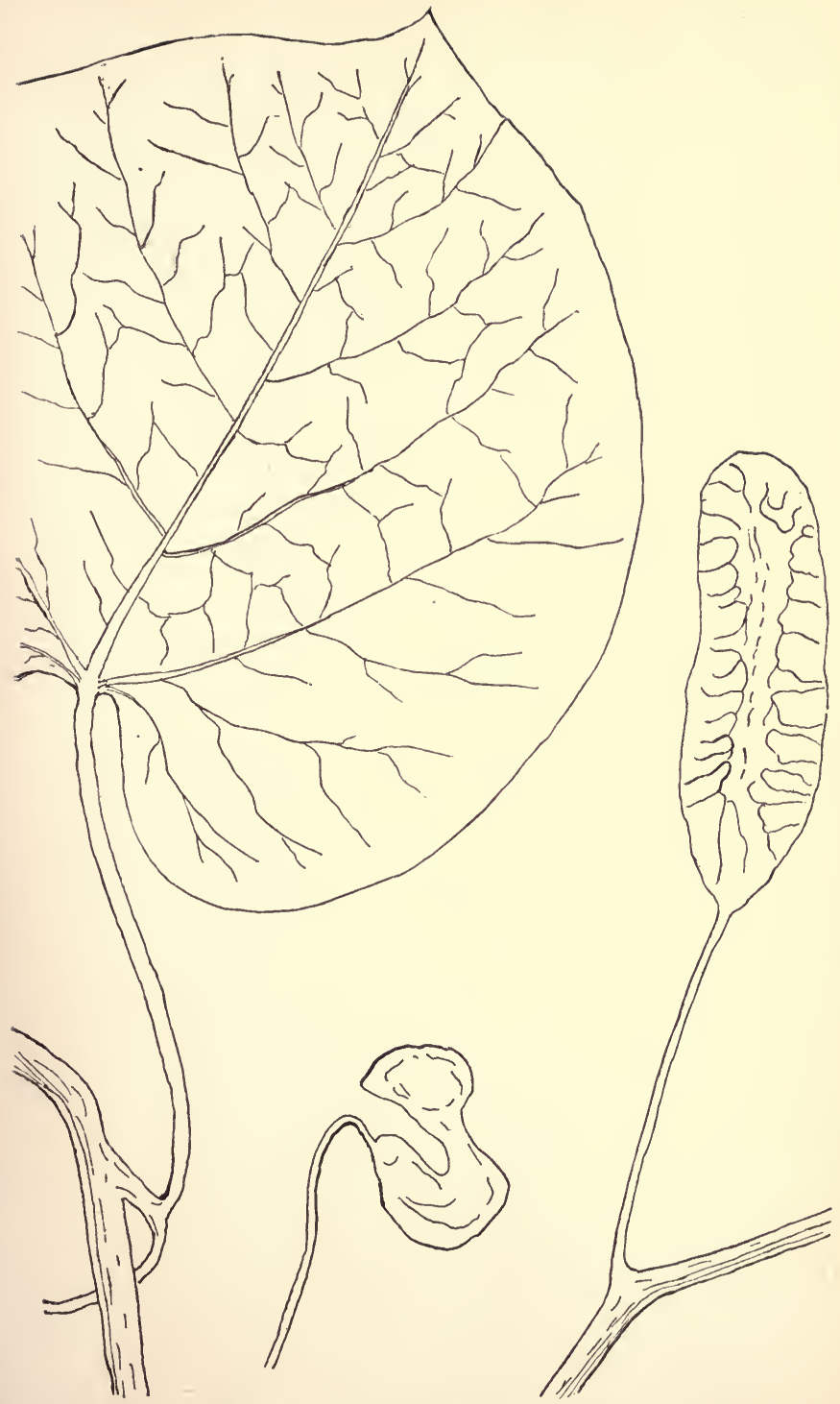


A vigorous, herbaceous climber, with stems six to ten feet long, or more, very rough downward-almost prickly. It is both ornamental and of great value commercially. The bitter and aromatic principle for which it is noted is due to small, reddish grains with which the calyx, fruit, and other parts are more or less dotted.

Darwin describes the motion of the Hop Vine in twining :

"When the shoot of a Hop rises from the ground, the two or three first-formed joints are straight and remain stationary, but the next-formed, whilst very young . . . bend to one side and travel slowly round all points of the compass, moving, like the hands of a watch, with the sun. The average time for one revolution is two hours and eight minutes."

He suggests an explanation of this motion :

"Let us suppose that the cells along the northern surface [of the revolving part] from the base to the tip were to grow much more rapidly than on the other sides, the whole shoot would then be bowed to the south. Let the longitudinal growing surface creep round the shoot, deserting by slow degrees the northern side, and encroaching on the western side, and so round by the south, by the east, again to the north. In this case the shoot would remain always bowed and with the point successively directed to each point of the compass."

The movement is not a twisting of the shoot, but a constant bowing, front, sideways, backwards, round and round until contact occurs or it stiffens with age. 


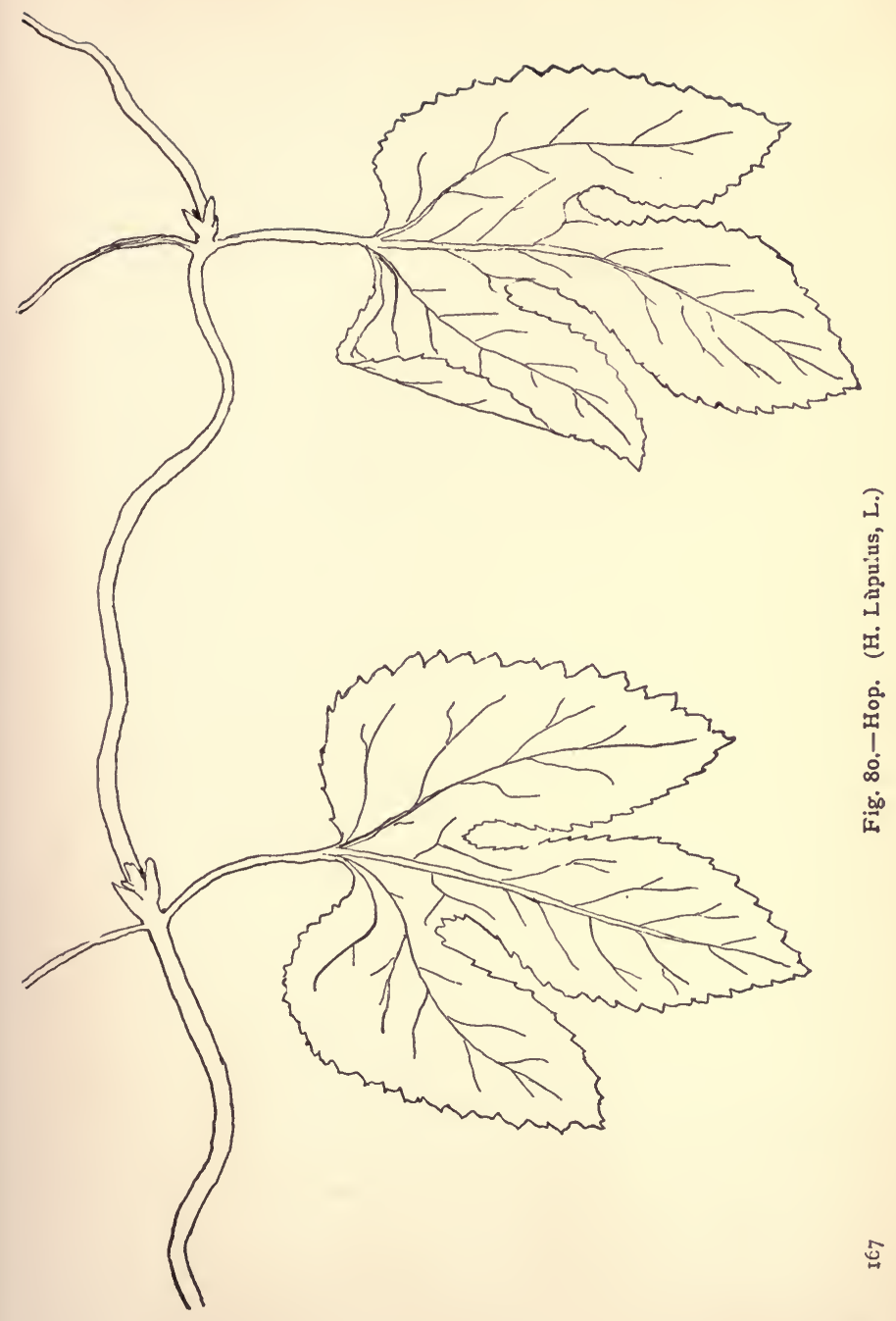





\section{CLASS SECOND}

ENDOGENOUS PLANTS (LEAVES MORE OR LESS NEARLY PARALLEL-VEINED FROM BASE TO APEX) 



\section{No. 25.-Family LILIÀCEÆ⿸ (Lily Fam.)}

Genus Smìlax, Tourn. (Green-Briar. Cat-Briar.)

From a Greek word meaning " yew."

Flowers, small (about one quarter inch or less in length), green or yellowish (or in No. 3-S. Wálteri, P.brownish), in small clusters from the sides of the branches; the perianth (calyx and corolla) of six similar divisions; the staminate and pistillate forms separate, on the same vine. Stamens, six, with linelike or narrow filaments, inserted at the base of the divisions. Stigmas, three (one in No. 9, S. laurifólia), thick and spreading, and nearly stemless. Seed-case, free, three-celled (one-celled in No. 9), with one or two young seeds in each cell.

Leaves, simple, alternate, entire or three-lobed, sometimes with the edge and mid-vein minutely bristle-toothed, strongly veined from base to apex, the veins more or less nearly parallel, usually smooth. Leaf-stems in most of the species kneed, and bearing at the bend a pair of tendrils, which in this genus probably are modified stipules.

Fruit, rounded, black when fully ripe (except in No. 3, S. Wálteri, P.), one- to three- (mostly three-) celled, one- to six- (mostly three-) seeded. A berry.

Found, very widely distributed. 
Slender vines, oftenest woody, climbing extensively by help of the tendrils of the leaf-stems. The sarsaparilla of commerce is obtained from the roots of various species.

\section{GUIDE TO THE SPECIES.}

(a) Herbaceous, annual, without prickles. Flowers illscented. Leaf-stems one third to one and one half inches or more in length.

(b) Leaves usually seven- or nine-veined, smooth. S. herbàcea, L.

(b) Leaves usually seven- or ninc-veined, downy beneath (I) S. herbàcea, var puberulénta, G.

(b) Leaves usually five-veined, the middle three often close and nearly parallel. (2) S. tamnifòlia, Mx.

(a) Woody, perennial, more or less prickly. Leaf-stem one quarter to three-quarter inch long.

(b) Leaves from rounded and egg-shape to fiddle-shape. Base mostly rounded or heart-shape.

(c) Stem of flower-clusters usually about the length of the leaf-stem or shorter, one twelfth to one half inch in length.

(d) Berries bright red. (3) S. Wálteri, Pursh.

(d) Berries blue-black. (4) S. rotundifòlia, L.

(c) Stem of flower-clusters longer than the leaf-stem, but seldom twice as long (except sometimes in No. 5). Prickles, when present, stout and broad-based (except sometimes in No. 5).

(d) Leaves not contracted at the middle. Edges not bristle-toothed.

(e) Leaf with a distinct whitish bloom beneath. (5) S. glauca, Walt.

(e) Leaf green beneath (without a bloom). S. rotundífòlia, $L$.

(d) Leaves usually more or less contracted at the middle. Edges often bristle-toothed. S. bòna-nox, L.

(c) Stem of flower-cluster two to four times the length of the leaf-stem. Prickles when present slender and needle-shaped (excepting sometimes in No. 5). 
(d) Leaf with a distinct whitish bloom beneath. (5) S. glaùca Walt.

(d) Leaf without a distinct whitish bloom beneath.

(e) Leaves not contracted at the middle. Base seldom or never heart-shaped. (7) S. híspida, Muhl.

(e) Leaves often contracted at the middle. Base more or less heart-shaped. (8) S. PseùdoChina, L.

(b) Leaves from oblong-lanceolate to very narrow. Base tapering. Cluster-stem not longer than the leaf-stem. (9) S. laurifòlia, L.

Fig. 8I.-(I) Carrion-Flower. S. herbàcea, $L$.

Flowers, greenish, ill-scented (like carrion), often in twentyto forty- (sometimes eighty-) blossomed clusters. Cluster-stems, often four to five inches in length. May, June.

Leaves, usually two to five inches in length, lance-shape to egg-shape or rounded, smooth (excepting in the variety), distinctly seven- or nine-veined. Base, heart-shape to squared or blunt. Apex, pointed, often bristle-tipped. Leaf-stem, one third to one and one half inches or more in length, bearing thread-like tendrils.

Stem, herbaceous, unarmed, three to fifteen feet in length. Fruit, red, ripening to bluish-black, very abundant. Seeds, two to six.

Found, common in thickets and low grounds, from Canada to Florida and Texas.

A very variable species. The tubers of the root-stock are short and thick.

Var. puberulénta, $G$. has the leaves somewhat downy beneath.

According to Thoreau, the odor of $S$. herbacea is equal to that of "a dead rat in the wall." 
Fig. 82.-(2) Yellowish Carrion-Flower. S. tamnifolia, $M x$.

This species differs from No. I, Carrion-Flower, chiefly in the following items :

Flowers, in ten- to twenty-blossomed clusters. Clusterstem, one to four inches long, very slender. July.

Leaves, from broad egg-shape to lance-shape, distinctly fiveto seven- (usually five-) veined, the three middle veins often close and nearly parallel. Lcaf-stem, one half to one and one half inches in length.

Fruit, one- to three-seeded.

Found, from the pine-barrens of New Jersey to South Carolina.

Resembling Fig. 83.-(3) Walter's Smilax. S. Wálteri, Pursh.

Flowers, usually brownish, in six- to fifteen-blossomed clusters. Cluster-stem, flattened, one sixth to one half inch long; not longer than the leaf-stem. Each flower-stcm, one sixth to one quarter inch long and very slender. April, June.

Leaves, usually three to four inches in length, egg-shape to oblong lance-shape ; three-veined (or five-veined, with the two outer veins indistinct), rather thick, smooth, green both sides, bristle-pointed. Base, slightly heartshape or rounded. Leaf-stem, one sixth to one half inch long.

Fruit, red, round, or sometimes oblong or pointed, two- to three-seeded.

Found, from Florida to North Carolina, and sometimes to the pine-barrens of New Jersey, usually in swampy grounds. 


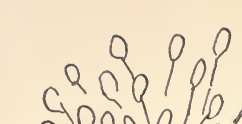

$a$
$a$ CE- $89000-3$ of 60000
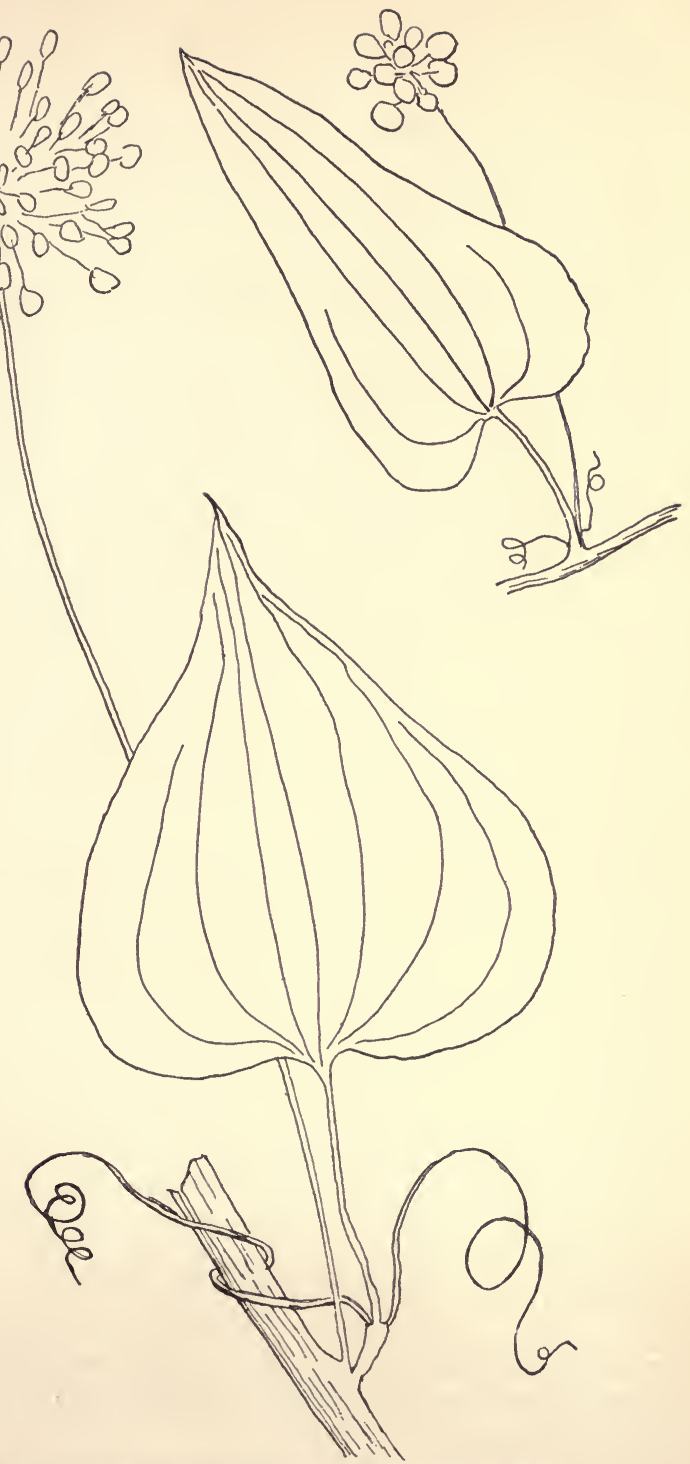

Fig. 82.-Yellowish Carrion-Flower. (S. tamnifolia, Mx.) 
A low woody vine, with the stem more or less angled, and usually beset with a few prickles toward the base ; six feet or less in length.

Fig. 83.-(4). Cat-Briar. Green-Briar. Horse-Briar. $S$. rotundifolia, $L$.

Flowers, in six- to twelve-blossomed clusters. Clusterstems, no longer, or, sometimes, only slightly longer than the leaf-stems; flattened. March, June.

Leaves, very variable in size, usually two to three inches in length, egg-shape to round, often broader than long; green on both sides, smooth, entire; five- or seven-veined, the three middle veins the strongest, oftenest leathery. Base, slightly heart-shape or rounded. Apex, abruptly short-pointed. Tendrils, strong, from the wings of the leaf-stem. Leaf-stem, one quarter to one half inch long. Prickles, stout and broad-based.

Fruit, round, blue-black, one- to three-seeded, often clinging throughout the winter.

Found, very common, especially in low, damp ground, from Canada southward to Georgia, and westward.

A woody vine, with the stem round or nearly so, and the branchlets often more or less four-sided; ten to forty feet in length; armed usually throughout with stout prickles. Stem and branches, oftenest yellowish-green. Root-stock running for long distances just under the surface of the ground, sparingly furnished with tubers, like those of $S$. glairca, but seldom in masses, as in that species.

Var. quadrangularis, G., has the branches-especially the smaller ones-strongly four-sided, and is more common westward. 


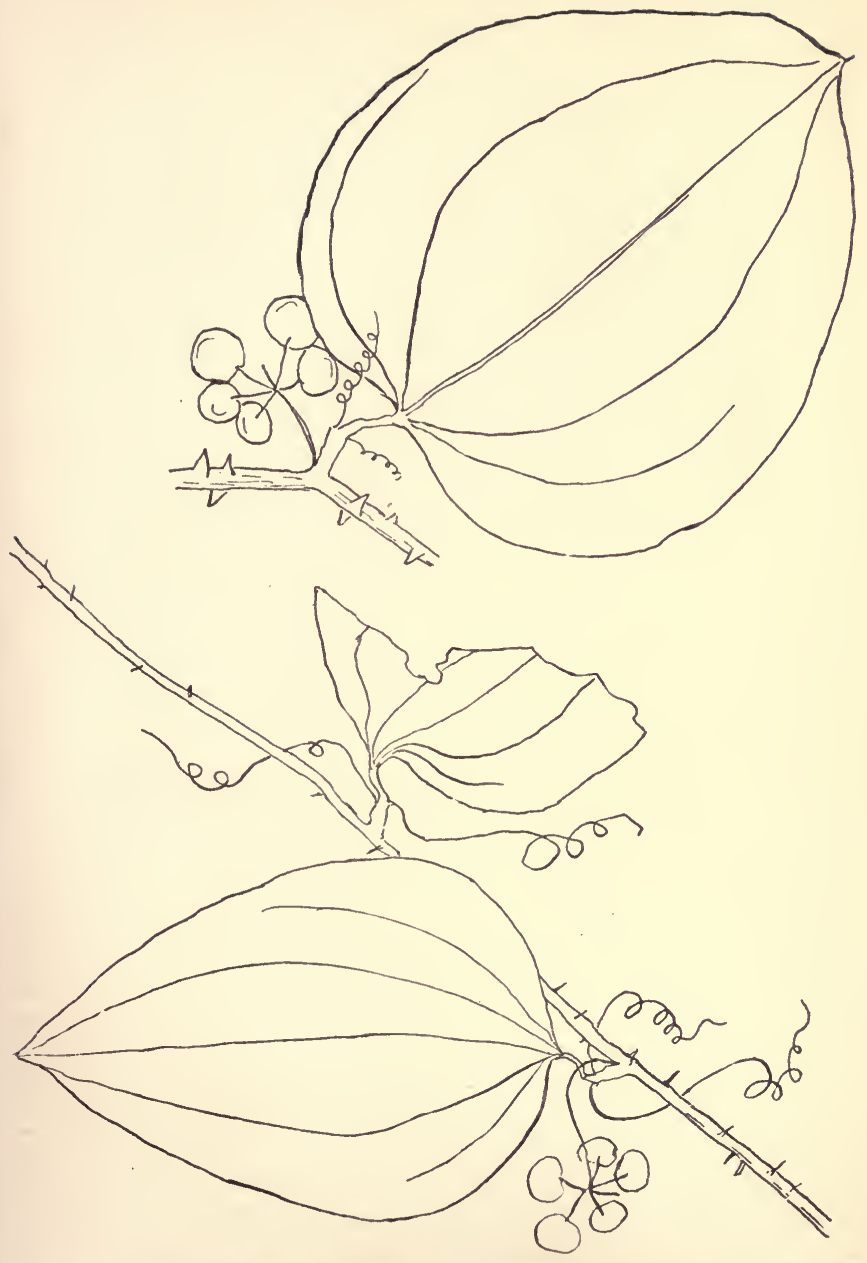

Fig. 83.-Cat-Briar. (S. rotundifòlia, L.)

Fig. 84.-False Sarsaparilla. (S. glaùca, Walt.) 
Fig. 84.-(5) False Sarsaparilla. S. glaùca, Walt.

Flowers, in six- to twelve-blossomed clusters. Clusterstems, flattened; two to three times as long as the leaf-stems; each flower-stem, one sixth to one third inch long. March, Jưne.

Leaves, usually two to four inches in length, egg-shape, varying from very broad to narrow egg-shape, entire; smooth, with a marked whitish bloom (glaucus) beneath and sometimes above; five-veined, the two side veins indistinct. Base, usually rounded and slightly pointed, often somewhat heart-shape. Apex, mostly rather blunt, with a sharp point. Leaf-stem, one quarter to one half inch long. Prickles, when present, usually slender.

Fruit, black, mostly two- to three-seeded.

Found, in dry thickets, from Massachusetts to Florida, and westward.

A woody vine with a round stem, sometimes armed with scattered prickles (either needle-like or triangular), sometimes unarmed. Branchlets, often covered, like the leaves, with a whitish bloom ; sometimes slightly triangular. Rootstock running deep, with tubers one to one and a half inches long, and one inch thick and often in masses.

Fig. 85.-(6) Stretch-Berry. S. bòna-nóx, L.

Flowers, twelve- to forty-blossomed, in clusters. Clusterstem, seven twelfths to one and two twelfths inch long (about twice as long as the leaf-stem); each flower-stem, one sixth to one third inch long.

Leaves, varying from heart-shape, usually with the middle slightly hollowed on each side, to strongly three-lobed, 


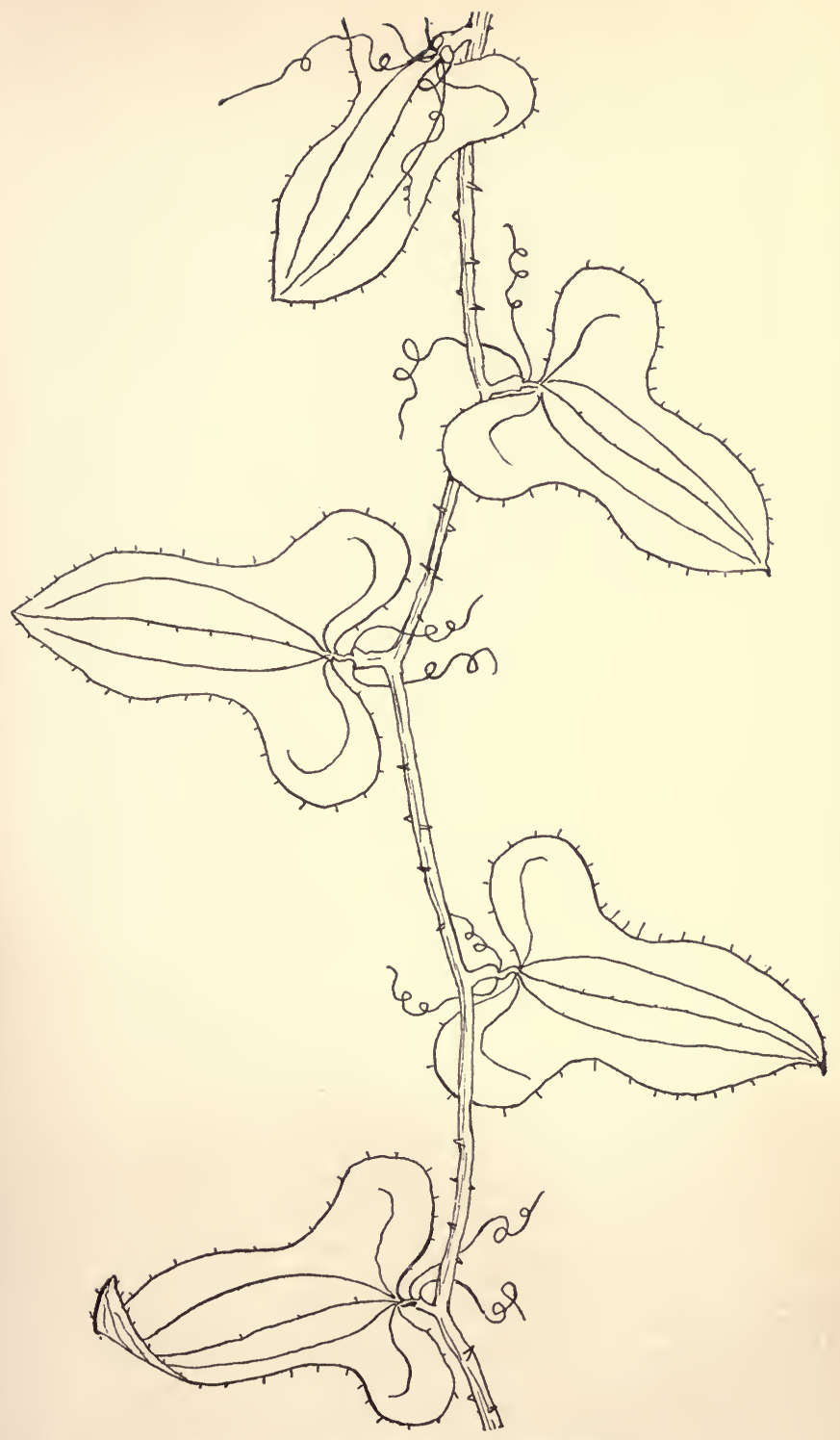


or even to fiddle-shape (i. e., with the middle very deeply hollowed); often minutely bristle-toothed along the edge and on the mid-rein ; often mottled. Leafstem, one quarter to one half inch long.

Fruit, round, black, usually one-seeded.

Found, from New Jersey to Florida and Texas.

A woody vine, eight to twenty feet in length, with the stem usually cylindrical and the branchlets angled; armed with short stout prickles. Stems and branches green.

Dr. Burrows states that the Indians make the tuberous roots into meal, which they use for bread or soup, under the name of coomte.

The name Stretch-Berry is due to the rubber-like elasticity of the pulp of the ripe berry.

Resembling Fig. 84.-Rough Smilax. S. hispida, Muhl.

Flowers, rather larger than in the common Cat-Briar (No. 83). Cluster-stem, flattened, three quarters to two inches in length, about twice as long as the leaf-stem, or more. June.

Leaves, usually three to five inches in length, egg-shape, never contracted at the middle, the larger ones more rounded, five-veined, rather thin, green on both sides. Apex, pointed. Base, rounded, unless in the larger ones, sometimes slightly heart-shaped. Edge, sometimes slightly roughened. Leaf-stem, one third to three quarters inch in length. Prickles, very weak, needle-like. 
Fruit, black, one- to three-seeded.

Found, from Connecticut westward and southward.

A woody vine eight to twelve feet in length. The stem is usually densely armed toward the base with long, very weak, needle-shaped, blackish prickles.

Fig. 86.-(8) False China-Briar. S. Pseido-China, L.

Flowers, in clusters of many blossoms. Cluster-stems, two to three inches in length-three times as long as the leaf-stem ; flattened. July.

Leaves, egg-shape to heart-shape, in old plants sometimes broader than long, often minutely bristle-toothed along the edge, five-veined, rather thin, green on both sides. Apex, bristle-pointed, Leaf-stem, short, Base, heart-shape or rounded.

Fruit, black, three-seeded.

Found, in dry soil from New Jersey to Florida and westward.

A woody vine. Stems cylindrical, purplish-brown, unarmed or rarely with a few weak prickles. Root with large tubers.

Fig. 87.-(9) Laurel-Leaved Smilax. S. laurifolia, $L$.

Flowers, in six- to thirty-blossomed clusters. Cluster-stem, cylindrical, one sixth to five sixths inch long, short, seldom longer than the short leaf-stem. Stigma, one. Seed-case, one-celled, one-seeded. June to August. 
182

Leaves, evergreen, thick, abundant; two to five inches in length, one half to two inches broad, from oblong lance-shape to very narrow, narrowing into a short leaf-stem; smooth above, paler below. Veins, three.

Fruit, black when fully ripe, ripening the second year, one-seeded.

Found, from the pine-barrens of New Jersey to Florida, and westward.

A woody vine with round and usually unarmed stems, often climbing to great distances.

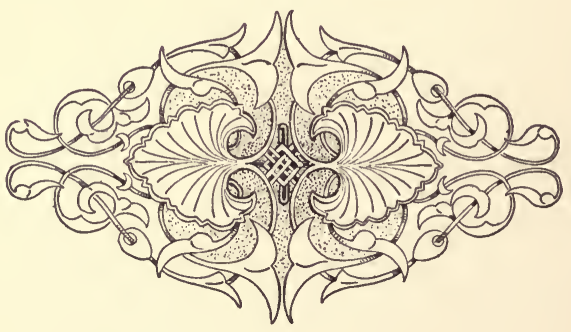




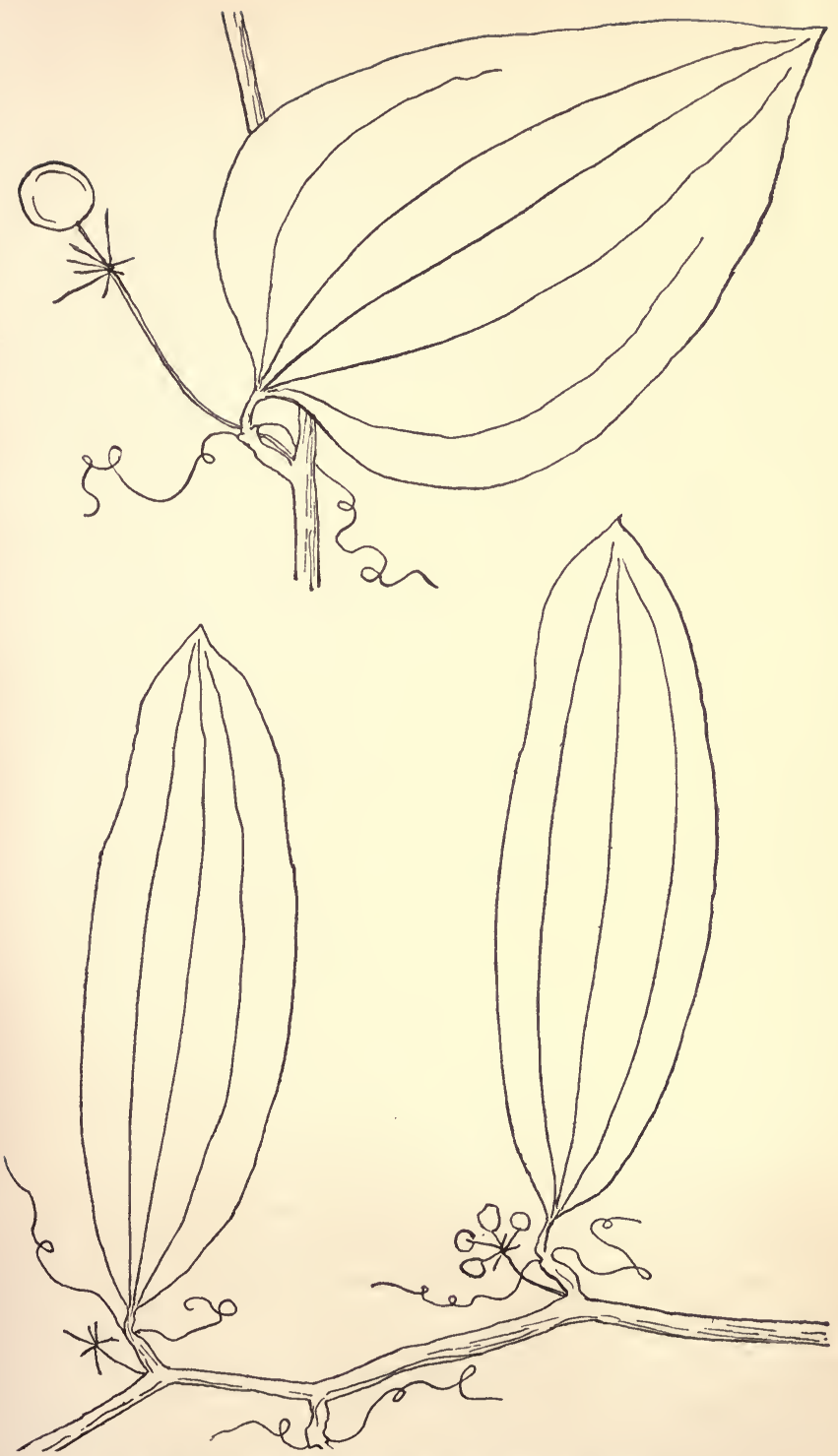

Fig. 86.-False China-Briar. (S. Pseùdo-Chìna, L.)

183

Fig. 87.-Laurel-Leaved Smilax. (S. laurifolia, L.) 

CLASS THIRD

ACROGENOUS PLANTS (FERNS AND CLUB-MOSSES) 


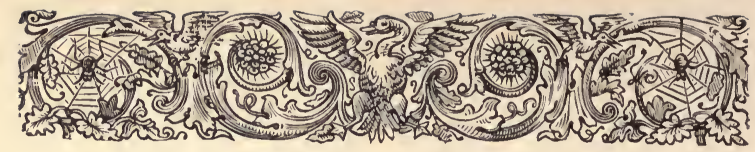

No. 26.-Family FíliCES. (Ferns.)

Genus Lygòdium, Swartz.

From a Greek word meaning " flexible."

Fig. 88.-Climbing Fern. L. palmàtum, Swartz.

Leaves (frondlets), simple, alternate in pairs, four- to sevenlobed; edges of the lobes entire, ends blunt, smooth. Fruit, scale-like dots, in double rows on the back of the narrower and smaller lobes of the variously divided upper leaves.

Found, oftenest in low ground, from Massachusetts to Virginia and Kentucky, and occasionally southward. Rare.

A very pretty climbing fern, one to three feet in length, slender and delicate. It is one of the few climbing ferns of the world, and the only one found in the United States.

No. 27.-Family LYCOPODIÀCE Æ. (Club-Moss Fam.) Genus Lycopòdium, L.

From two Greek words meaning "wolf" and "foot."

Leaves, evergreen, small, simple, crowded, usually entire, lance-shape or awl-shape (excepting sometimes in the spikes), one-veined, in four to many ranks. 


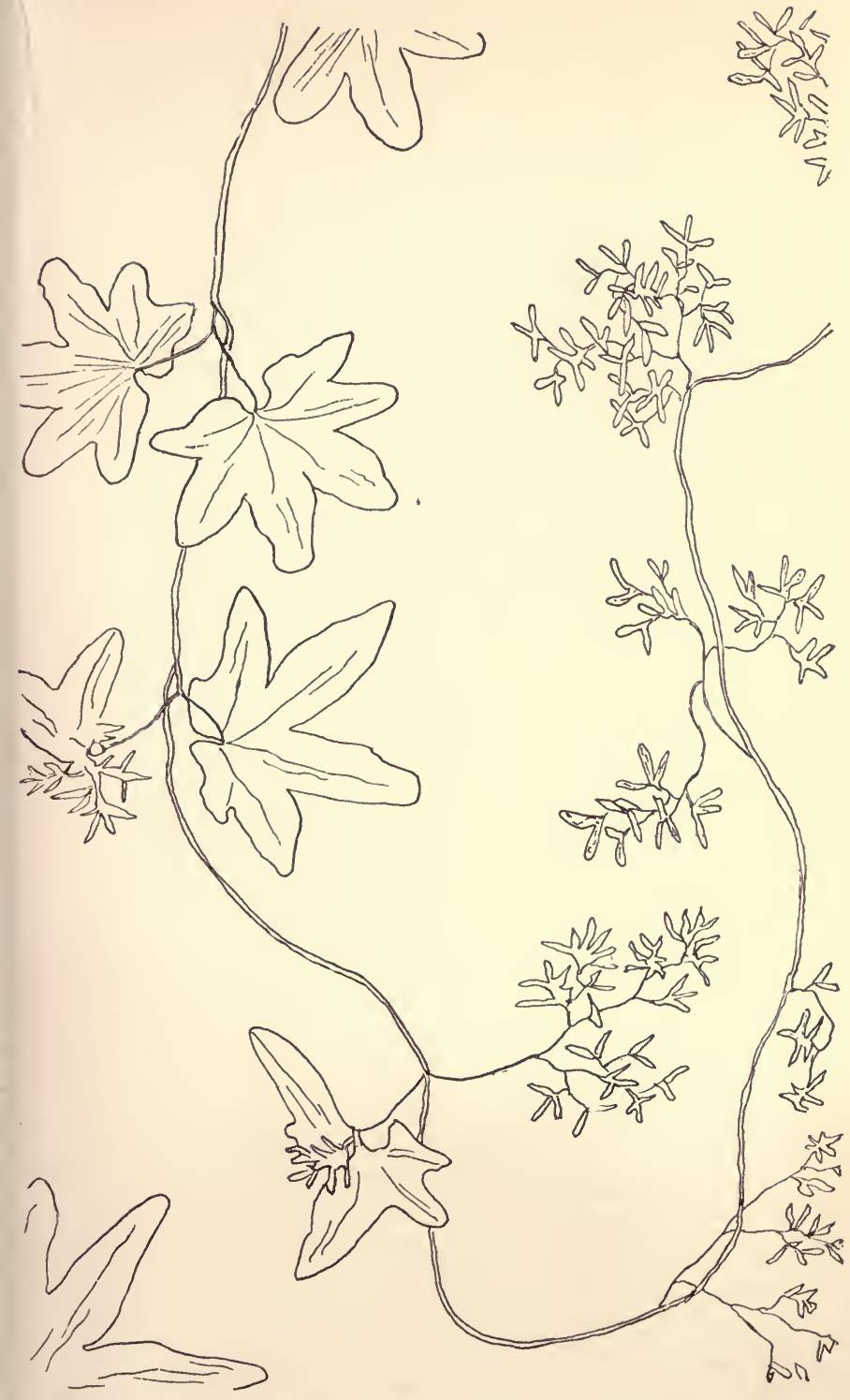

Fig. 88.-Climbing Fern. (L. palmàtum, Swartz.) 
Fruit, one-celled, kidney-shaped spore-cases, in the angles of the upper leaves or scales (forming more or less distinct spikes that are sometimes sessile at the ends of the branches and sometimes stalked), filled with yellow inflammable dust-like spores.

Low evergreen perennials. The spore-dust is very inflammable, and is used in the manufacture of fireworks. It is also sold by druggists under the name of Lycopodium powder, to prevent the chafing of tender skin.

\section{GUIDE TO THE SPECIES.}

(a) Branches not flattened. Leaves around the branches of one kind.

(b) Spikes stemless. (I) Interrupted Club-Moss (L. annótinum, L.).

(b) Spikes stemmed. (2) Common Club-Moss (L. clavàtum, L.).

(a) Branches much flattened. Leaves around the branches of two kinds. (3) Festoon Ground-Pine (L. complanàtum, L.).

Fig. 89.-(r) Interrupted Club-Moss. L. annótinum, $L$.

Leaves, of the stem and branches alike, spreading, minutely toothed near the tip, stiff, lance-shape, pointed, in about five rows : those of the spikes, scalelike, yellowish, egg-shape or heart-shape.

Stems and branches, cylindrical, creeping, one to four feet in length, much branched. Branches, erect, four to eight inches in height, two- to three-forked, leafy throughout. Spike, terminal, stemless, at the summit 


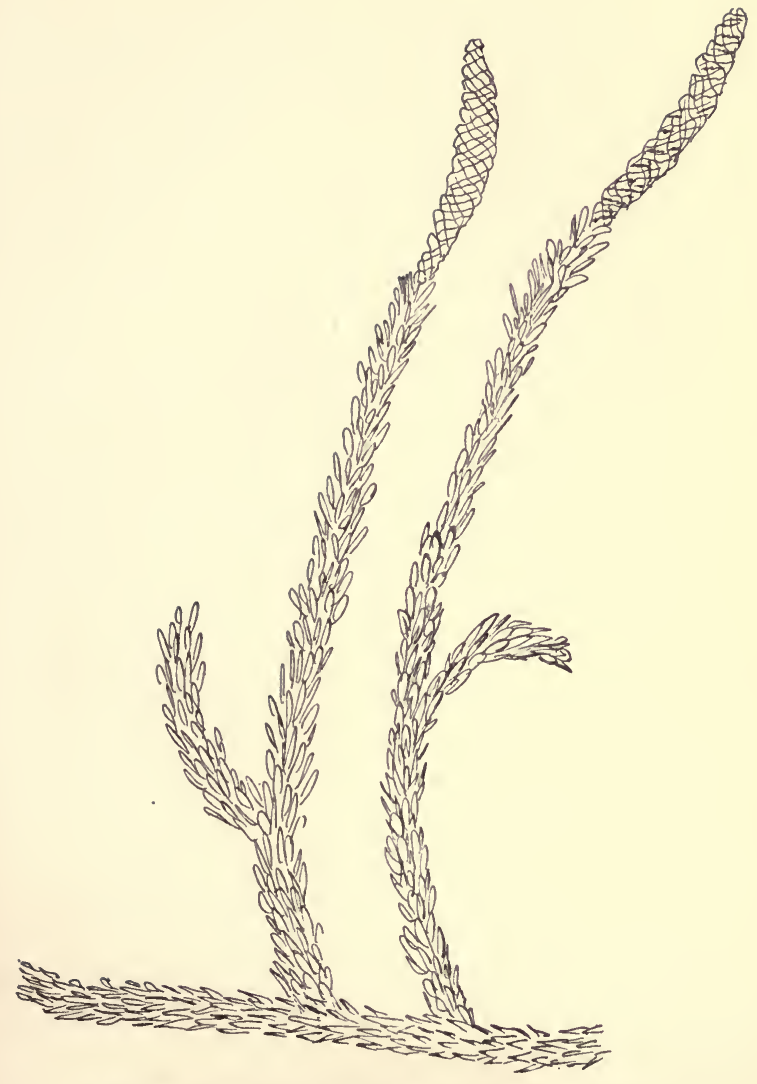

Fig. 89.-Interrupted Club-Moss. (L. annótinum, L.) 
of the fertile branches, about one inch in length, thick, solitary, cylindrical. July.

Found, in woods, in New England and Canada, rather common.

Var. pringens, Spring, is a reduced form found on the White Mountains.

Fig. 90.-(2) Common Club-Moss. L. clavàtum, $L$.

Leaves, of the stem and branches alike, in many rows; narrow awl-shape, many of them with a double curve; all tipped with a long, fine bristle. Leaves of spikes, scale-like, minute, yellowish, egg-shape or heart-shape, also tipped with a slender bristle.

Stems and branches, cylindrical, creeping extensively, branches two to five inches long, erect, very leafy, simple or often forked, the fertile ones terminated by a slender stalk four to six inches in length, which bears the one to four (usually two or three) slender, cylindrical bristly spikes, one to two inches in length. July.

Found, in dry woods, from the mountains of North Carolina northward. Common, especially northward. It is much used at the north for Christmas decorations.

The Lycopodium powder of druggists and of fireworks manufacturers is obtained chiefly and in great quantities from this species. 


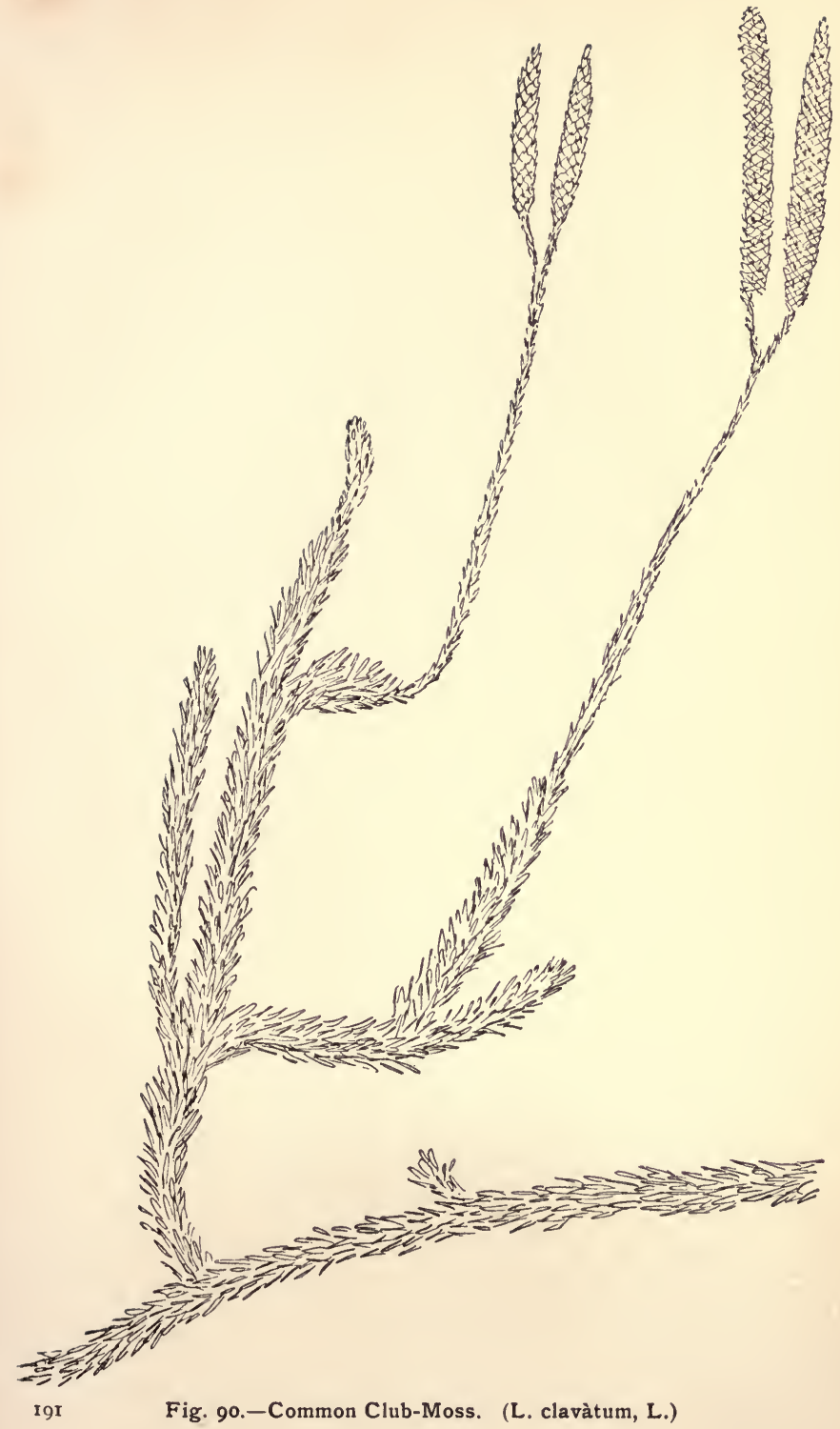


Fig. 91.-(3) Northern Ground-Pine. Festoon Ground-Pine. $L$. complanàtum, $L$.

Leaves of the stem and branches awl-shape, sharp; those on the flat branchlets in four distinct rows, and of two forms, namely: the two marginal rows with spreading tooth-like leaves; the two surface rows with much smaller and closely pressed leaves (giving thus a saw-like look); those of the spikes scale-like, yellowish, egg-shape or heart-shape.

Stems, round, creeping extensively among the leaves and moss, two to ten feet in length, often underground. Branches, two to three inches long, more or less erect once- or twice-forked, and then divided into many very flat branchlets. Fertile branches, terminated by a slender stalk bearing the two to six cylindrical fruiting spikes, each spike one inch or more in length. Branchlets, crowded, much flattened, spreading (fanlike), somewhat resembling in form a spray of ArborVitæ or White Cedar. July.

Found, common in woods and thickets, especially northward.

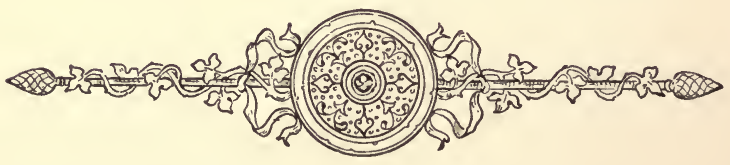




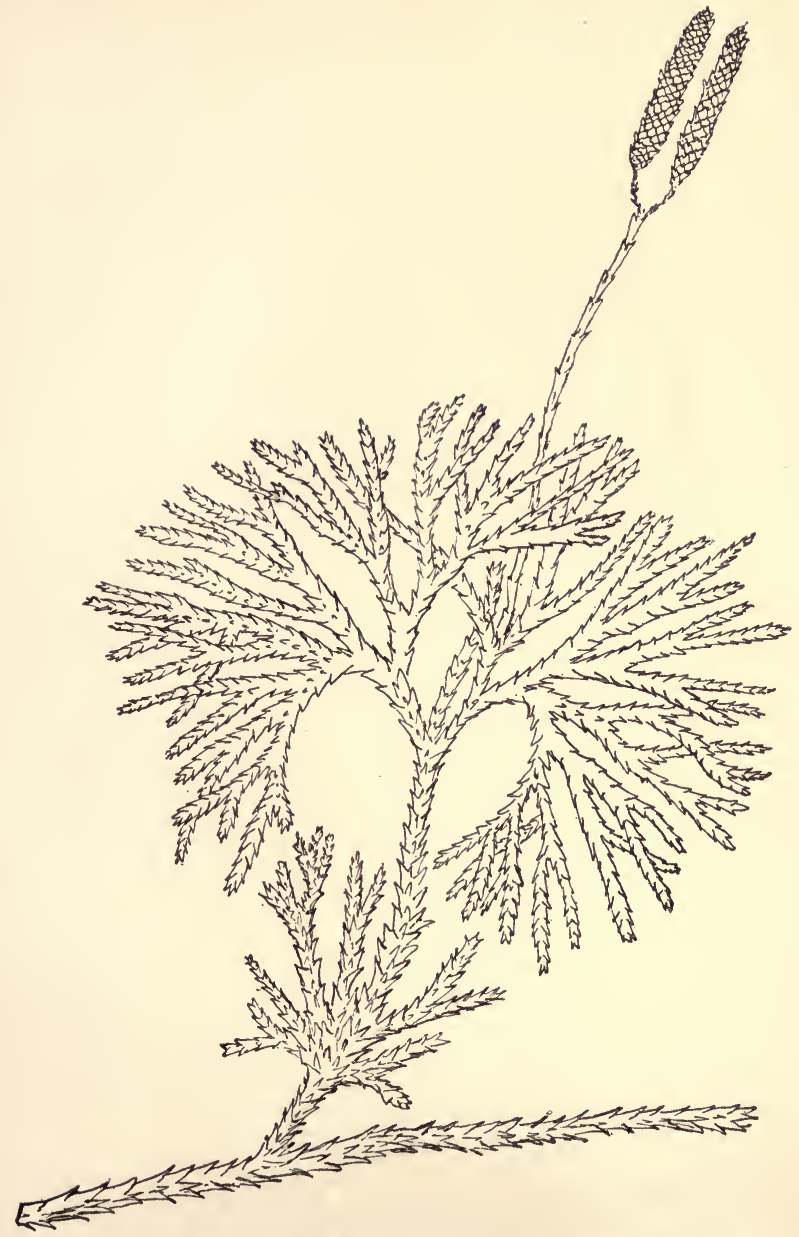

Fig. 91.-Northern Ground-Pine. (L. complanàtum, L.) 

Farewell, ye kindly companye,

Each vine and shrub and tree, Dear friends to me ;

Farewell again, ye God-sent companye. 

EXPLANATION OF TERMS 



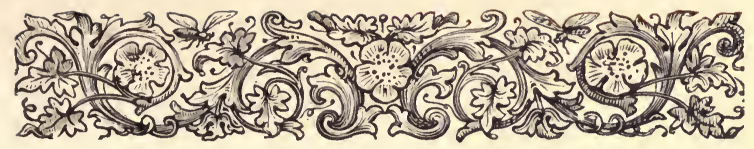

\section{EXPLANATION OF TERMS.}

I.

The term "vine" is used broadly to indicate such growths as are too weak for self-support.

II.

THE FLOWER.

(1) The flower, when complete, is composed of petals, Fig. a (I) ; sepals, Fig. a (2) ; stamens, Fig. b (1), with filament, Fig. b (2), and anther, Fig. b (3); pistil, Fig. b (4), with seed-case, Fig. b (5); style, Fig. b (6), and stigma, Fig. b (7).

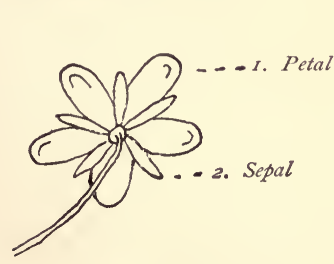

Fig. a.

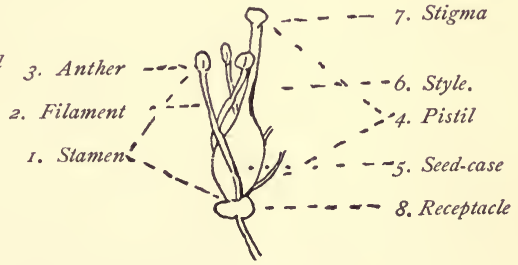

Fig. b.

These parts are supported by the receptacle, Fig. b (8). The corolla (crown), is the circle of the petals; the caly'x (cup), is the circle of the sepals.

(2) The flower is pistillate, when the pistil is present 
and the stamens are lacking ; staminate, when the stamens are present and the pistil is lacking.

(3) The seed-case is free, when it is not attached along its sides to the calyx ; adherent, when it is so attached.

(4) The flower is terminal, when it is at the end of a branch; axillary, when it springs from the base of the

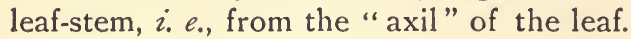

III.

THE FRUIT.

The fruit consists of the ripened seeds and their wraps. (For the different kinds see the Fruit Guide, page xxvii.)

IV.

THE LEAF.

(I) A leaf is simple, when it is of one piece; compound, when there are two or more entirely distinct parts, called leaflets, on the one leaf-stem.

A compound leaf is feather-shaped, when the leaflets are placed along the sides of the leaf-stem ; hand-shaped, when all the leaflets radiate from the end of the leaf-stem, like fingers from the palm of the hand.*

(2) The leaf is entire, when its edge is an even line without indentation; toothed, when it is set with an indefinite number of sharp or blunt teeth; lobed, when the indentations are deep and of a definite number.

(3) The leaf is needle-shaped, or line-shaped, when it is very narrow, or sometimes scarcely more than a line; lance-shape, when it is much longer than wide, and gradually tapering to a point ; inversely lance-shape, when

* Note 1.-Compound leaves may be once, twice, or three times compound.

Note. 2.-The leaflets of a compound leaf can be distinguished from a simple leaf by the absence of leaf-buds from the base of their stems. 


\section{Explanation of Terms.}

gradually tapering down instead of up ; egg-shape, when it is of the general shape of an egg, with the broadest part below the middle, but without regard to the form of the base and the apex; inversely egg-shape, when it is the shape of an egg, but with the broadest part above the middle; oval, with the broadest part at the middle.

(4) The leaf at its apex may be pointed, taper-pointed, bristle-pointed, blunt, or rounded.

(5) The leaf at its base may be squared, rounded, pointed, wedge-shape (when it tapers to a point by straight lines), or heart-shape.

(6) The leaves as arranged upon the branch may be alternate, when they follow one another upon different sides of the branch ; opposite, when they are in pairs and on opposite sides of the branches; indeterminate, when they are small and closely crowded up and down the branches, e.g., the club-mosses.

V.

(I) Stipules are appendages of the nature of a leaf, but of various forms, found in some plants in pairs at the base of the leaf-stems, e. $g$., in the Pea.

(2) Stipels are small stipules found in some plants at the base of the leaflet-stems.

(3) Bracts are small appendages of the nature of a leaf, but of various forms, found oftenest in connection with, or just below, the calyx.

(4) The axil of a leaf is the angle between the leafstem and the branch. 


\section{GLOSSARY.}

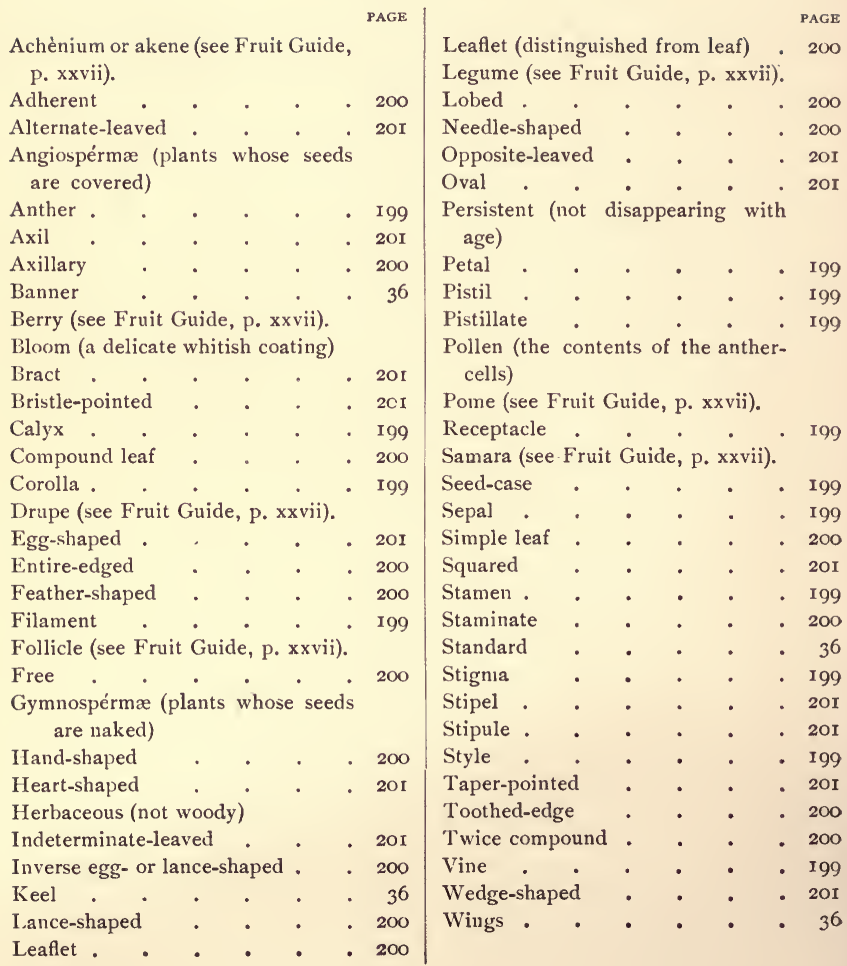




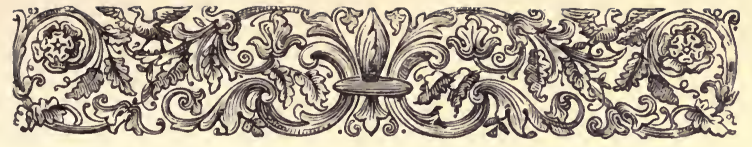

\section{INDEX OF VINES.}

The names of families are given in HEAVY CAPITALS, of genera in SMALL CAPITALs, of species and of varieties in " roman type," and synonyms in italics. The names of introduced species are enclosed by brackets.

A

ADLÙ̀mA cirrhòsa fungòsa

AMPELPósis quinquefòlia

AMPHICARPæ̇̇a commòsa mondica

Pítcheri

ANACARDIÀCE

ÁPIOS tuberòsa

Arbutus, Trailing

ARISTOLOCHIÀCE $Æ \quad . \quad ~ 163$

ARISTol6́chia Sipho . . . 163

ASCLEPIADACEA • • • 124

Atrágene Americànus . . . 6

B

Balsam-Apple, Wild

[Baltimore Belle] .

Beach-Pea

Bearberry

Bean, Few-flowered Kidney .

Kidney

Umbelled Kidney $\quad$. $\quad$ • 44

Various-leaved Kidney. . 44

Wiid' (A. tuberòsa) . . 54

Wild (P. polystáchyus) . 42

Bedstraw, Hairy . . . 102

Rough . . . . 100

Small . . . . IOI

Sweet-scented . . IOI

BIGNONIA .

BIGNONIÀCE $\mathbb{E}$

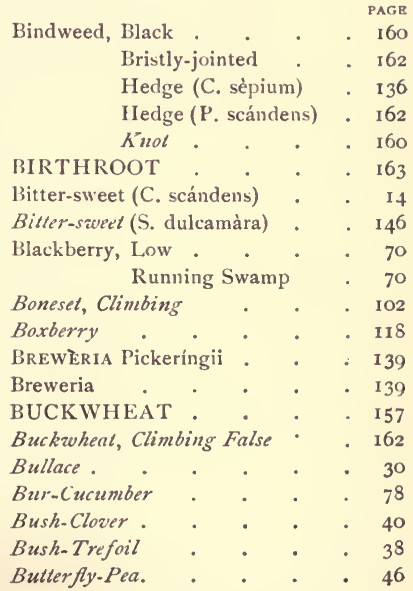

C

CAPRIFOLIÀCE $£$. . . 87

Carrion-Flower . . . . I73

Carrion-Flower, Yellowish . . 174

Cat-Briar . . . . . 176

CELASTRÀCEÆ . . . 14

CELÁstrus scándens . . 14

Checkerberry . . . . 118

Chicken Grape . . . . 26

China-Briar, False. . . . $\mathbf{1} \delta \mathbf{I}$ 


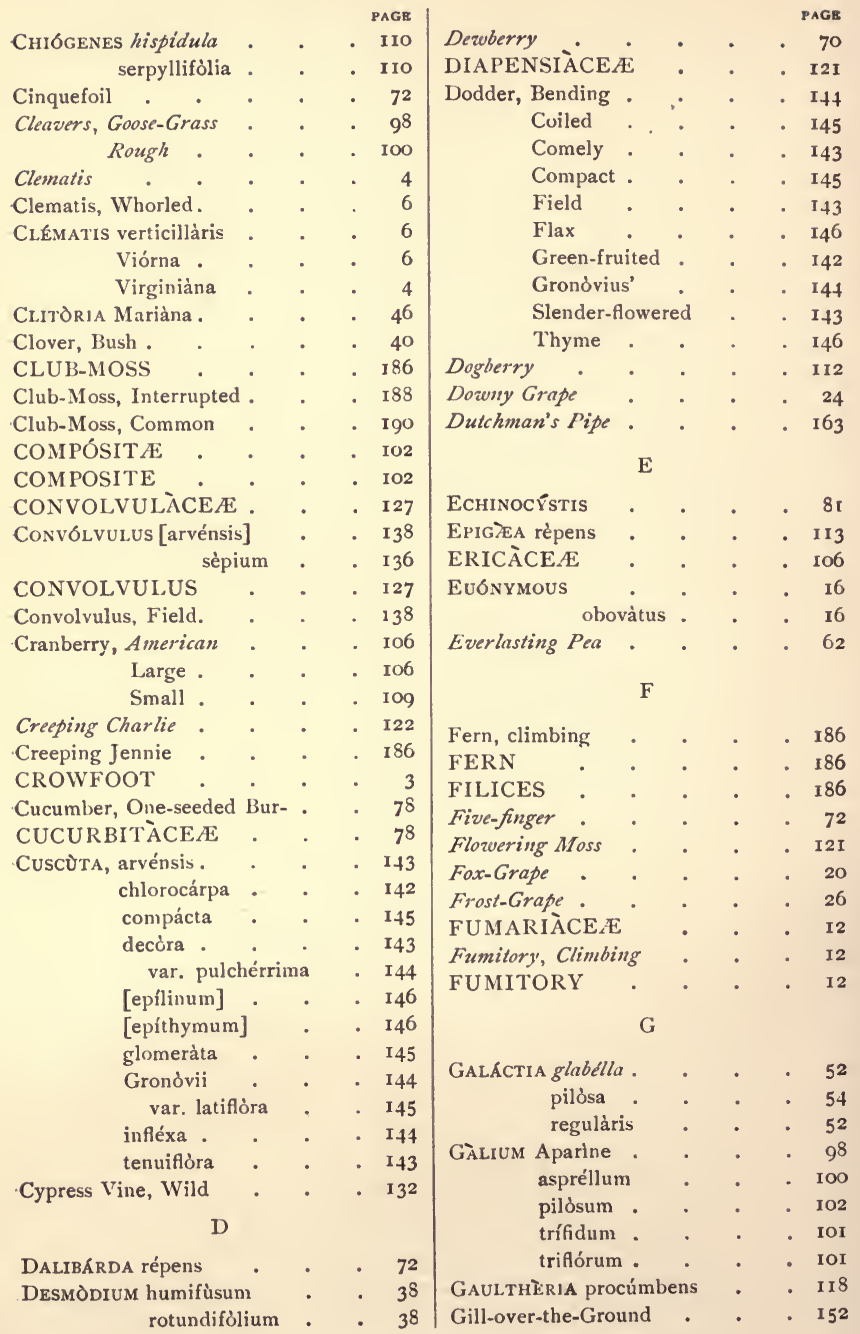




\section{Index of Vines.}

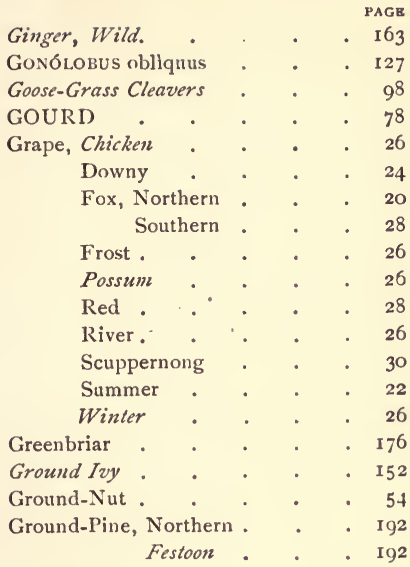

II

HEATH . • . . 106

Hemp-IVeed, Climbing . • . IO2

Hog-Peanut (A. commòso) . . $4^{8}$ (A. Pítcheri) . $\quad 50$

HONEYSUCKLE • • $\quad 87$

Honeysuckle, Evergreen . . 90 hairy · · 92 Japanese $\cdot{ }^{\circ} \cdot 9^{2}$ Trumpet . . . 90 Yellow (L. gràta) . 90 Yellow (L. Sullivántii) 94

Hop • . . . . . 164 Horse-Briar . . . . . 176 HÙmulus Lùpulus ․ . $16_{4}$

\section{I}

IPOMìA [coccínea] [hederàcea] lacunosa . panduràta. [purpùrea] [quámoclit]

Ipomœa, White Star Ivy, American Ivy, Poison
PAGE

Kidney-Bean . . . . . 42

Knotweed . . . . . 157

Knotweed, Bristly-jointed . . 162

L

LABIÀT E . . . . . $\mathrm{I}_{52}$

LATHYRUS marítimus . . . 64

ochroleùcus . . . 64

[odoràtus] . . 62

palústris . . 66

var. myrtifòlius . 66

praténsis . . 68

venòsus . . . 66

Laurel, Ground . . . . 113

Leather-Flower . . . . 6

LEGUMINÒS $\Subset$. . . $\quad 36$

LESPEDÈZA procúmbens . . . 40

repens.

LILIACEAE . . . . . I7I

LINNitA boreàlis . . . . 87

LONÍCERA glaùca * . . $\quad$. 94

gràta . . . 90

hirsùta . . . . 92

[Japónica] . . . 92

sempérvirens . . 90

Sullivántii . . . 94

Love Vine . . . . . 139

Lìcium [barbárium] . . . 148

[vulgàre] . . . 148

LYCOPODIÄCE $A$. . 186

LycopòdIUM annótinum . . 188

clavàtum .
comcopòdIum

complanàtum . . 192

LYGòdIUM palmàtum . . . $\mathbf{1 8 6}$

Lysimàchia [nummulària] . . 122

\section{M}

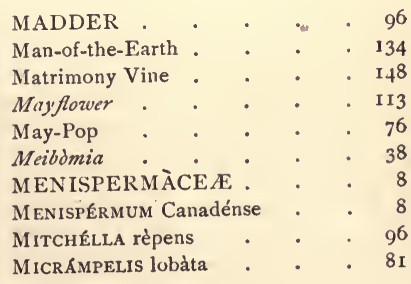




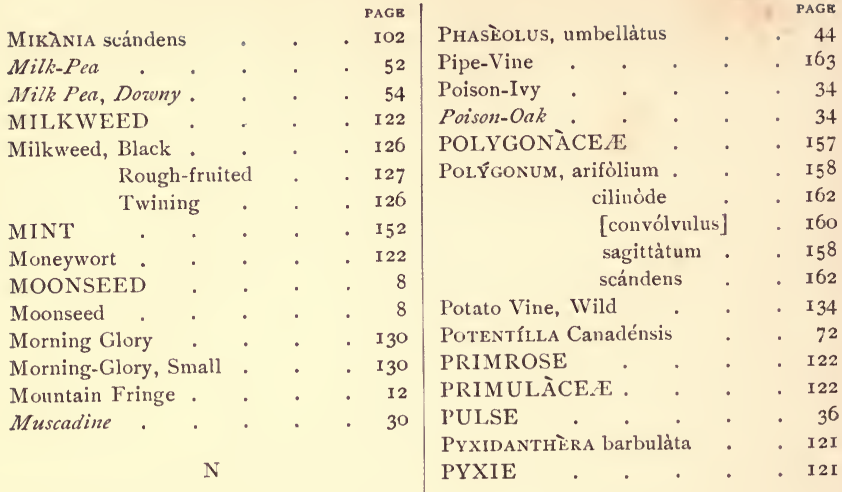

NÉPETA Glechoma • • . ${ }^{52}$

NETTLE . . . . . I64

NIGHTSHADE . . . . 146

Nightshade, Woody . . . 146

$\mathrm{O}$

Oak, Poison .

P

Partridge-Berry (G. procúmbens) . II 8 Partridge-Berry (M. rèpens) . . 96 PASSIFLORÃCEÆ . . . 76

PAssiflòra [cœerùlea] . . . 77 incarnàta . . . 77 lìtea . . . 76

PASSION-FLOWER . • . 76

Passion-flower, Blue . . . 77

Ýellowish . . 76

Pea, Beach . . . . . 64

Butterfly . . . . 46

Downy Milk . . . 54

Milk . . . . 52

Sweet . . . 62

Peanut, Hog . . . 48,50

Periplodea [Græca] . . . . 126

Phasèolus, diversifdlius . . 44 hélvolus . . . 44 pauciflòrus . . 46 perénnis . . . 42 polystáchyus . . 42
R

RANUNCULÀCEÆ • • • 3

Raspberry, Dwarf . . . . 69

RHús rádicans . . . . 34

toxicodéndron . . . 34

ROSACEE . . . . 68

RòSA setígera. $\quad . \quad$. $\quad$. 74

ROSE . . . . 68

Rose [Baltimore Belle] • . . 76

Climbing . . . 68

Michigan $\quad \cdot \quad . \quad .68$

Prairie. . . . 68

RUBIÀCE $Æ$ • . . 96

Rùbus Canadénsis . . . 70

híspidus . . . 70

triflòrus . . . . 69

Rutland Beauty . . . . 136

Sarsaparilla, Big . . . . 163

Sarsaparilla, False . . . . 178

Scratch-Grass . . . 158

Sícyos angulàtus . . . 78

SMìlax bòna-nox . . . $177^{8}$

glaùca . . . 178

herbàcea . . . 173

var. puberulénta . . $\mathbf{I 7 3}$ 


\section{Index of Vines.}

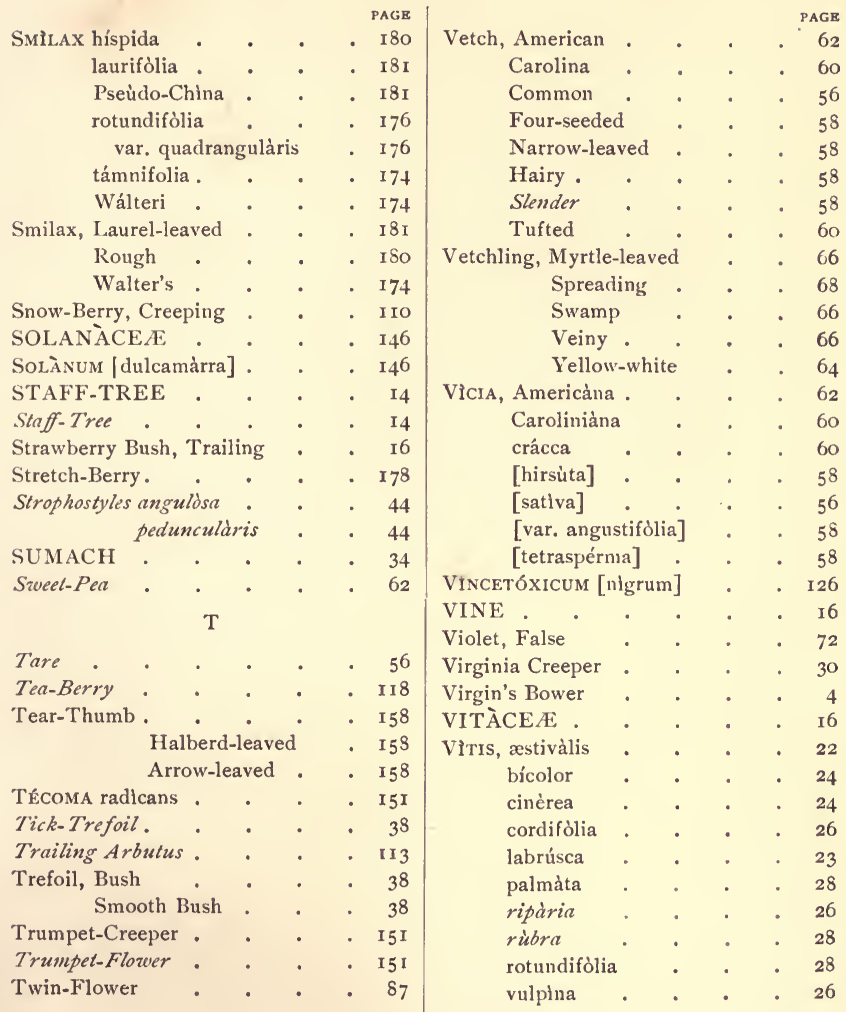

W

URTICÀCE $Æ$. . . . 164

V

VACcfinum macrocárpon . . 106 occycóccus .

Waxwork . . . . . I4

Wintergreen . . . . 118

Woodbine . . . . . 30

Woodbine, American . . . 90 


THIS BOOK IS DUE ON THE LAST DATE STAMPED BELOW. 

